\title{
PROMOTION OF LEARNING IN INDIA \\ DURING MUHAMMADAN RULE (BY MUHAMMADANS)
}

NARENDRA NATH LAW

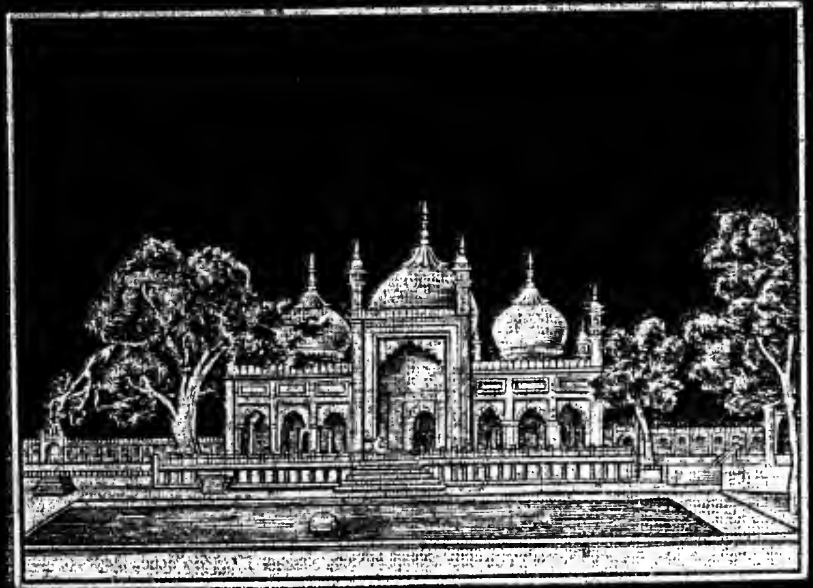




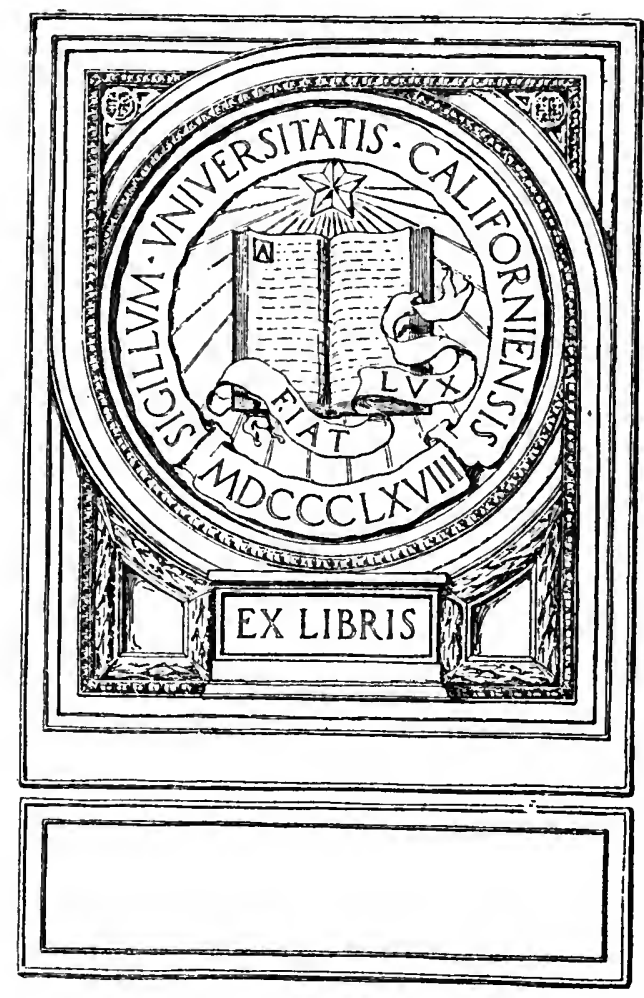




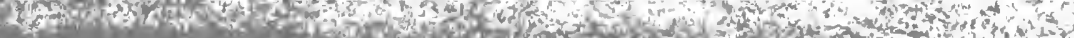

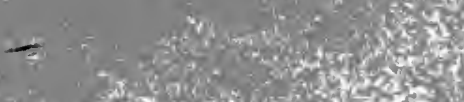

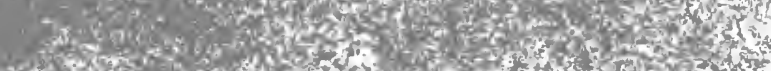

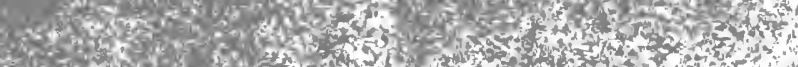

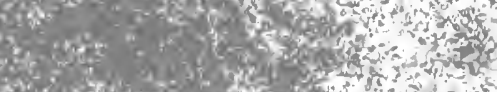

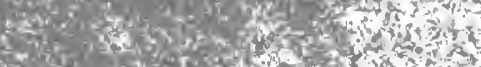

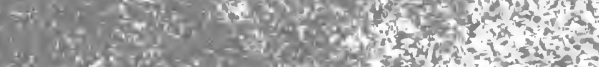
19.

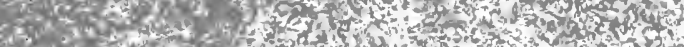

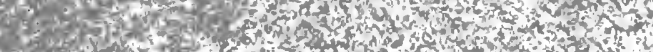

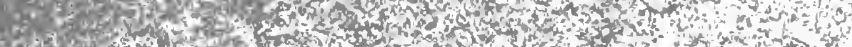

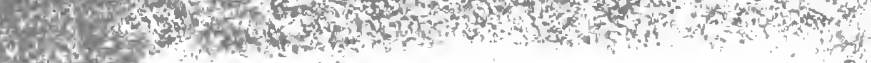
Sos on:

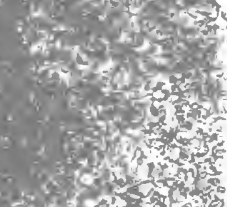

की m.t.

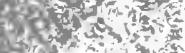
ond in

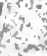

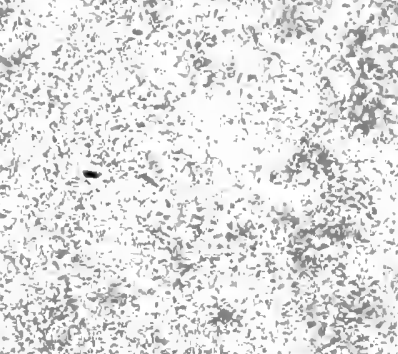

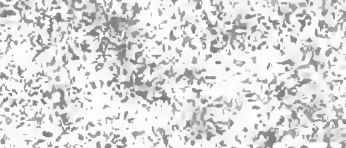

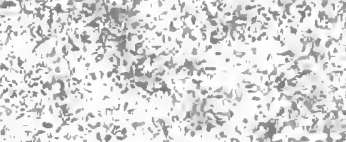
ise ? tion tor. $x^{2}+1$

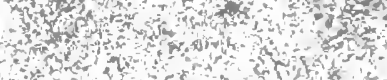

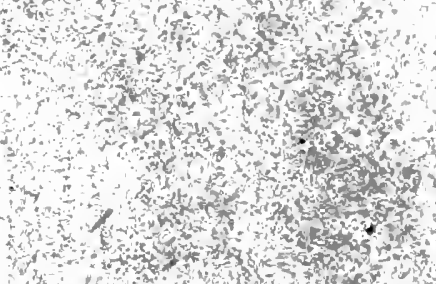
and

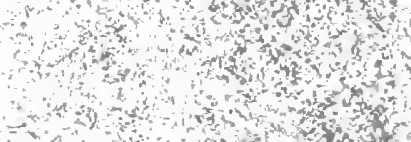
and and ind

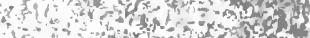
W

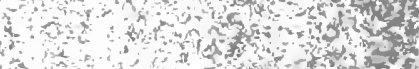

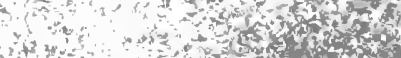

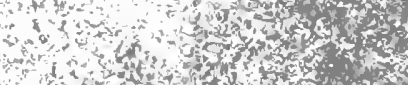

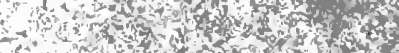

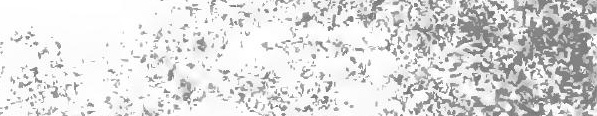

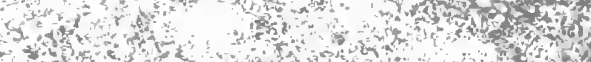

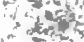

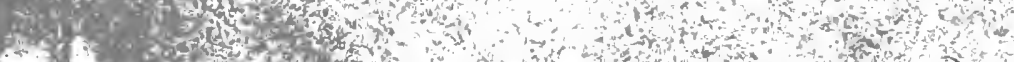
in

trat 
Digitized by the Internet Archive in 2007 with funding from

Microsoft Corporation 


\section{PROMOTION OF LEARNING IN INDIA DURING MUHAMMADAN RULE (BY MUHAMMADANS)}




\section{WORKS BY THE SAME AUTHOR}

\section{STUDIES IN ANCIENT HINDU POLITY.}

Vol. I. Based on the "Arthasâstra" of Kautilya. With an Introductory Essay on the Age and Authenticity of the "Arthasâstra" of Kautilya by Professor Radhakumud Mookerji, Ph.D., M.A. Crown 8 vo, price $3 s$. $6 d$. net.

\section{PROMOTION OF. LEARNING IN INDIA.}

By Early European Settlers (up to about I800 A.D.). With an Introduction by the Venerable WALTER K. Firminger, M.A., B.D., Archdeacon of Calcutta. With 2 Illustrations. Crown 8vo, price 4 s. $6 d$. net.

LONGMANS, GREEN AND CO.

LONDON, NEW YORK, BOMBAY, CALCUTTA, AND MADRAS

IN PREPARATION.

STUDIES IN ANCIENT HINDU POLITY.

Vol. II. (The Machinery of Administration.)

(In the press.)

\section{PROMOTION OF LEARNING IN INDIA.}

By the Hindus.

During the Nineteenth Century and After.

THE FOUNDATION OF HINDU ECONOMICS (Bārtā).

STUDIES IN ANCIENT HINDU LAW. 
, :

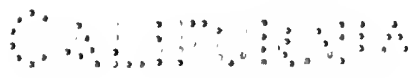



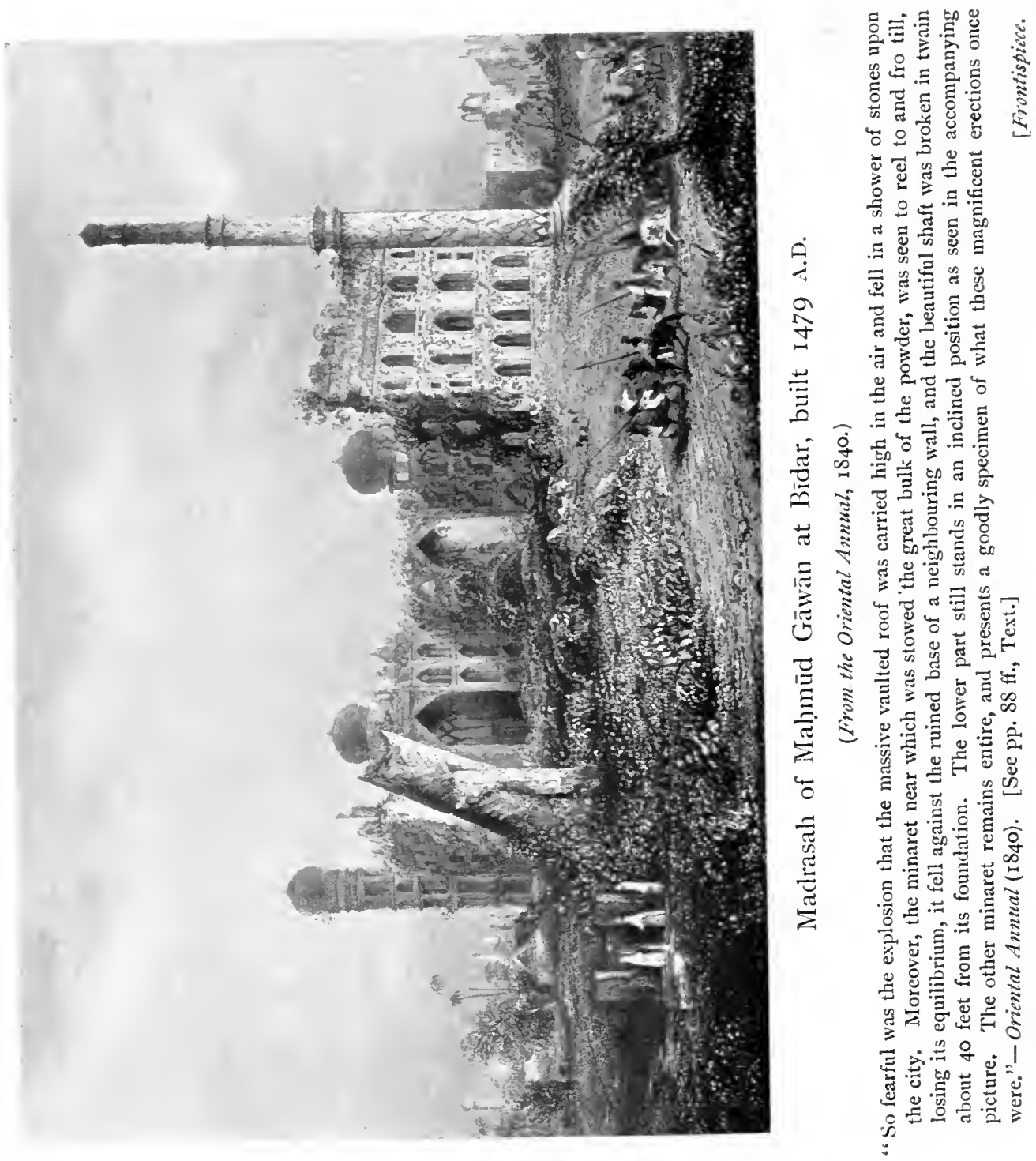


\title{
PROMOTION OF LEARNING IN INDIA
}

DURING MUHAMMADAN RULE

(BY MUHAMMADANS)

\author{
BY \\ NARENDRA NATH LAW, M.A., B.L. \\ PREMCHAND ROYCHAND SCHOLAR, CALCUTTA UNIVERSITY \\ AUTHOR OF "STUDIES IN ANCIENT HINDU POLITY," ETC.
}

WITH A FOREWORD

BY

H. BEVERIDGE, F.A.S.B., I.C.S. (RETIRED)

WITH ILLUSTRATIONS

LONGMANS, GREEN AND CO. 39 PATERNOSTER ROW, LONDON FOURTH AVENUE AND 30TH STREET, NEW YORK BOMBAY, CALCUTTA, AND MADRAS;

I 9 I 6

All rights reserved 


$$
\begin{aligned}
& 2 A !^{51} \\
& 2^{19}
\end{aligned}
$$


TO

THE MEMORY

OF

MY REVERED GRANDFATHER

MAHARAJA DURGA CHURN LAW, C.I.E.

A PATRON OF LEARNING

A PRINCE OF MERCHANTS

A PROMOter OF CIVIC WELL-BEING 



\section{PREFACE}

THE purpose of the present work is to bring together all the facts about a most interesting aspect of Muhammadan rule in India which is apt to be missed in the general histories of that rule. The contributions to learning and culture made by Isläm in India are indeed worthy of a special consideration. Their value is more abiding if less brilliant than the political conquests which marked the progress of Muhammadan power in India.

The work, as its title indicates, relates to the promotion of learning and not to the quality of the learning. It is generally stated, though not on unreasonable grounds, that India was devoid of Muhammadan scholarship of the type found in the centres of Muslim learning outside India, and that the Muhammadan literati of India lagged far behind the scholars of such places as Baghdād, Dimashq, Cairo, Cordova, Makkah, Shīrãz, Samarqand, etc.

This is not, however, a sufficient reason why we should cast into perpetual oblivion the earnest and praiseworthy efforts that were made by the 


\section{PREFACE}

Muhammadan emperors, chiefs and private individuals of India to promote learning and diffuse education among the people of this country. Such efforts should be appreciated apart from the results achieved, and the credit due to them should in no way be diminished by the meagreness of those results. The present work is a history of such efforts and an attempt to show in a connected narrative that the long roll of Muslim rulers, emperors and invaders from Mahmūd downwards were not altogether inattentive to the literary interests of the people, and that private individuals also were not quite inactive in this direction.

As to the value that can be attached to the materials used in this work, it should be remarked that the Muhammadan historical works should not be wholly relied upon. They mix up facts with fiction in such a manner that it is often difficult to distinguish the one from the other. Under the circumstances, a question may arise as to how far they can be regarded as trustworthy. No doubt, the question is not without its difficulties. I have followed the principle that where the same fact has been stated by different writers following different authorities, that fact may be relied upon, especially if the authors happen to be contemporaneous with the facts recorded. Sometimes, it may transpire that a fact connected with the subject is mentioned in a work which is considered as an authority in its 


\section{PREFACE}

field; in that case, if there be nothing improbable or unreasonable about it and if it be uncontradicted by any other evidence, we may safely accept and use it. To reject the uncorroborated testimony of a contemporaneous writer or the statements of a writer generally accepted as an authority, if there be nothing unreasonable or improbable about them, would be wantonly rejecting historical materials and carrying scepticism too far. Many of the authorities cited and followed in this volume were respected by their contemporaries, and have been used as authorities by various writers on historical subjects.

It is further to be noted that incidental allusions to facts are perhaps more trustworthy than their direct accounts. In such cases, the element of personal bias finds no reason or scope for its exercise, and there is no motive for any exaggeration, misstatement or distortion. I have therefore pieced together such scattered allusions and references on account of their intrinsic importance as a source of reliable evidence.

So far as I am aware the subject-matter of this work has not anywhere been systematically treated. The materials for its compilation lie scattered in works published and unpublished, in most of which they are only indirectly and incidentally referred to. This made the work of my research greatly difficult, as after considerable labour, I had to give 


\section{PREFACE}

up as many works wherein I did not find the needful materials as those in which I did find them. I have not only used the original works of European and Indian writers and translations of original works, but have also utilized many manuscripts and printed texts, Arabic, Persian and Urdu, in the Library of the Asiatic Society of Bengal as also in the Bohār Collection of the Calcutta Imperial Library, as will be evident from the Bibliography.

My grateful acknowledgments are due to Prof. Radhakumud Mookerji, M.A., Premchand Roychand Scholar and author of $A$ History of Indian Shipping, etc., and to my uncle, Mr. Nundolal Dey, M.A., B.L., author of the Geographical Dictionary of Ancient and Mediaeval India, for valuable help rendered and kind revision of the work. I am also under obligation to Maulawī 'Abdul Ahad for assisting me in the handling of Persian MSS., and to Maulawī Hāfize. Nažìr Aḥmad, Chief Research Maulawì, A.S.B., for revising the transliteration of Arabic and Persian terms.

I also owe a deep debt of gratitude to $\mathrm{Mr}$. H. Beveridge, F.A.S.B., I.C.S. (retired), for his many valuable criticisms and suggestions and kind revision of the proofs in spite of his many pre-occupations.

I have also to acknowledge with pleasure and gratitude the receipt of help of various kinds from Dr. Brajendra Nath Seal, M.A., Ph.D., Prof. Benoy 


\section{PREFACE}

Kumar Sarkar, M.A., Mr. J. H. Elliot, Asst. Secy., A.S.B., my brother Mr. Surendra Nath Law, Maulawī Asadul Zaman Khān Gauhar, Nawāb 'Abdul Raḥmān Bahādur, Khān Șāhib 'Abdul Walī, Mr. Surendra Nath Kumar, Mr. Kumud Lal Dey, Messrs. Bejoy Krishna and Jugal Kishore Nundy and Mr. Moni Mohun Sil.

My special thanks are due to my cousins Messrs. Nalin Chandra Paul, B.L., and Satya Churn Law, M.A., B.L., for material assistance. Mr. Satya Churn Law has further helped me in the reproduction of the illustrations.

Finally, I have much pleasure in expressing my thanks to Mr. Ramananda Chatterji, M.A., editor of the Modern Review, in which appeared portions of this work, since considerably modified, and to the authors and publishers who have kindly given me permission to reproduce illustrations.

\section{NARENDRA NATH LAW.}

96, Amherst Street,

Calcutta,

September, r9r5. 



\section{FOREWORD}

My friend, Mr. Narendra Nath Law, the grandson of a famous citizen of Calcutta, has asked me to write an introduction to his book on the Promotion of Learning in India, and I willingly comply with his request, as it is always a great pleasure to see Indian gentlemen taking an interest in the history of their country. But some practice during a long life has never made composition an easy matter, and the subject which Mr. Law has chosen is only partially familiar to me. My studies in Indian history began late, and were mainly concerned with the sixteenth and seventeenth centuries, whereas Mr. Law's work covers, like Livy's History of Rome, a period of over seven centuries. He begins with Sulțān Mahmūd of Ghaznī, whose date is some forty years earlier than the Norman Conquest, and ends, for the present, with the close of the eighteenth century. This volume, which is in two books, the first dealing with the Pre-Mughal Period, and the second with the Mughal Dynasty, is now before me. It breaks new ground, for though there have been several literary histories 


\section{FOREWORD}

of India, this is, I think, the first work which specially deals with the share taken by her Muhammadan conquerors in the promotion of Indian learning. As Mr. Law puts it in his Preface, "So far as I am aware, the subject-matter of this work has not anywhere been systematically treated. The materials for its compilation lie scattered in works published and unpublished, in most of which they are only indirectly and incidentally referred to."

As I have said, Mr. Law begins with Sulțān Maḥmūd of Ghaznī. He was the son of a Turkish slave, and a great iconoclast. A village in Afghanistan is still known by the name of Būtkhāk, or Idol-dust, because Mahmūd is said there to have had Hindu idols broken to pieces. Maḥmūd is, perhaps, chiefly remembered nowadays for his rapacity, and for his breach of promise to Firdausi ; so far is it from being true that genius and priority of enterprise have the privilege of being able to commit great mistakes with impunity. The remark is made by Voltaire, who says, in his Siècles de Louis XIV. et de Louis XV., "C'est le privilege du vrai génie, et surtout du génie qui ouvre une carrière, de faire impunément de grandes fautes." Voltaire is here speaking of the Great Condé, and Count Noer applies it to Akbar with reference to his claim to Divine honours. But the remark is not satisfactory in respect of either of these heroes, and Voltaire is in himself a striking instance of its 


\section{FOREWORD}

falsehood, for he is seldom thought of without the amari aliquid arising of his ribald treatment of Joan of Arc. Such was the impression produced by Sulțān Maḥmūd's love of plunder that the poet Sa'dī represents a Persian king as seeing Mahmūd in a dream, a hundred years after the Sulțān was dead. "The body had decayed and crumbled into dust, all save the eyeballs which rolled in their sockets, looking hither and thither. None of the soothsayers could give the interpretation; but a certain poor man put in his word and said, ' $\mathrm{He}$ is searching because his kingdoms have passed away to another.'

But Mahmūd was much more than a ruthless buccaneer. He was a magnificent prince and a liberal patron of literature. He loved Afghanistan and his mountain-nest of Ghazni, and adorned it with buildings and tanks, and made it a centre of light and leading. One would have thought that this would have appealed to the Emperor Bābur, who also loved Afghanistan and directed that he should be buried in Kabul. But he forgot what Ghaznī was before a brutal Afghan-'Alāu-d-din Ghorī, the World-Burner (Jahānsoz) - had destroyed it, and says in his Memoirs, "Ghaznī is but a poor, mean place, and I have always wondered how its princes, who possessed India and Persia could have chosen such a wretched country for the seat of their government." The Troll-gardens of Agra and 


\section{FOREWORD}

Bengal soon killed off Bābur, just as Gaur enervated his opium-eating son. Possibly, when Bābur wrote the above remarks, he was thinking bitterly of how his life-long friend and comrade in arms, Khwāja Kilan, the Crillon of many forays, had flouted the glories of India, and had abandoned it and his master in order to return to the snows of Ghazni.

Sulțăn Maḥmūd's injustice to Firdausī did not take place till after many years of patronage, and was the inevitable result of morose old age and religious bigotry. It may be said too with truth that his extravagant promise of a gold coin for every line that Firdausī wrote, by awaking dreams of the potentiality of wealth, did more harm to the poet than was caused by the subsequent repudiation. It encouraged Firdausi to spin out his poem to the length of nearly I20,000 lines, and so caused the repetitions and the "intolerable length" of which his editor, Captain Turner-Macan, so justly complains. And though Maḥmūd's reputation must suffer for his faithlessness, yet it brought this compensation, that it called forth from Firdausi in his old age the Sative, which is perhaps the most forcible and heart-felt thing that any poet, Eastern or Western, ever wrote. Here we are reminded how literature is indebted to Chesterfield's neglect of Johnson for rare old Samuel's celebrated letter. Firdausī's Sative was not all just, and he forgot 


\section{FOREWORD}

past favours, just as Johnson forgot or ignored the fact that Chesterfield had given him when he was needy and ragged the handsome present of ten pounds.

Mahmūd seems also to have been unfortunate in his relations with Alberuni, the other immortal of the Sulțann's court. It should, however, be noted that the words quoted by Mr. Law in his first chapter, p. I3, from Sachau are only the latter's inference from some remark of Alberuni. Alberuni does not, I understand, name Mahmūd, nor accuse him of not doing his duty as a patron. It is just as likely that he is referring to the apathy of Indian Rajahs. Even if Mahmūd be meant, it is to be remembered that he belonged to a hostile country, and that he owed his imprisonment and exile to Mahmūd. This would not help to make him just to the Sultān. The probability is that Alberuni was very little at Ghaznī during Maḥmūd's lifetime, and so had small opportunity of experiencing his bounty. His great work, the Canon Masudicus, was dedicated to Mahmūd's son, after returning from India, where he must have spent years. Here I should note that the Canon Masudicus is still unedited, though there are several copies in Europe, and also one in the Mullā Fīrūz Library at Bombay. It should also be noted that the name Anwar Khān, in the quotation from Ferishta on p. I2 of Mr. Law's first chapter, is a mistake of Briggs's for Abu Rihān. 


\section{FOREWORD}

From Mahmūd, Mr. Law passes on to the House of Ghor. He rigorously sticks to his thesis of the promotion of learning, and so says very little about Muḥammad Ghorī (Mu'izzu-d-dīn b. Sām), whose conquests, as Elphinstone truly says, were far greater as regards India than those of Mahmūd. It was he who defeated the Rajah of Ajmere, and was the first real conqueror of India. It is his victories over Hindus that earned him the title of Sultān Ghāzī. Nor does Mr. Law say much about Muḥammad Ghorī's slave and viceroy, Quṭbu-d-din Aibak, who ruled India for four and twenty years and founded the Quṭb Minār which implies that he promoted Art, if not Letters. It was completed by Shamsu-d-din Altamash, who was Qutbu-d-din's son-in-law. He too was originally a Turkish slave, and is said to owe his curious sobriquet to his having been born during an eclipse of the moon (Bada'inini I., Ranking's translation, p. 88). Altamash was an enlightened prince, and showed his sense by appointing his daughter, Sultān Rezia, as his successor, instead of his sons.

The Slave-kings were followed by the House of Khilji. The most distinguished member of this house was 'Aläu-d-din Khiljī. Among other things, it was he who brought the Koh-i-Nür to Northern India. He was brutal and ignorant, but he was a great administrator, and many of his measures were adopted by Sher Shāh and Akbar. Lord Bryce $\mathrm{xviii}$ 


\section{FOREWORD}

somewhere says that President Krüger's natural vigour of mind was not diluted by education, and the same may be said of 'Alāu-d-din, who could not even read or write.

In his chapter on Akbar, Mr. Law disbelieves the story of his illiteracy, in spite of his son's statements, as well as those of the Catholic missionaries, and he relies on the spurious Memoirs which were translated by Major Price. That these Memoirs are spurious is the view of so great an authority as Dr. Rieu, and is also proved by the fact that they contain statements which it is impossible that Jahāngīr can have written. Mr. Law also thinks that though 'Alāu-d-dīn was originally unlettered, he afterwards took to study, learnt to read royal addresses and became acquainted with the best Persian authors. For this he relies upon a passage in Briggs' translation of Ferishta. The sentence in the original Persian is a little obscure, and I am not quite certain of the meaning, but judging from the Newal Kishore text, p. I Io (describing 'Alāu-d-din's reign), it seems to me that the passage in Briggs is partly a flourish of the General's and partly a mistranslation. What, I think, Ferishta says is that 'Alāu-d-dīn used to have papers and books read to him, but he found that his munshis falsified the purports, and so gave up the practice. Afterwards he substituted for these readings the putting of questions to learned men, xix 


\section{FOREWORD}

and getting their vivâ voce answers. But whatever Ferishta meant to say, it is clear that he is merely abstracting Barnī, who is his chief authority for the reign of 'Alāu-d-dinn. Barnī's accounts will be found in the Bib. Ind. edition of his work, p. 289 et seq., and also, though with many lacunæ, in Elliot's History of India, iii. I83, etc. Barnī says nothing about 'Alāu-d-dīn's proficiency, any more than does Ferishta, in the Persian, speak of his private studies. According to Barnī, 'Alāu-d-dīn had no acquaintance with learning, and never associated with the learned. He also represents 'Alāu-d-din as saying, "Although I have not studied the Science or the Book, I am a Musalmān of a Musalmān stock" (Elliot, iii. 189). The original of this passage will be found at p. 295, six lines from foot of the Bib. Ind. ed., and is more explicit than in Elliot. What'Alāu-ddin says there is, "Though I have not any knowledge, and have not read anything-agarchi 'ilmi $u$ kitābi nakhwānda äm-yet I am Muhammadanborn, and my family has been Muhammadan for generations."

But Mr. Law need not have doubted Akbar's illiteracy, for the East teems with instances of distinguished administrators who could neither read nor write. For example, we have the Prophet Muhammad, who was known as the unlessoned prophet, and we have 'Alāu-d-dīn Khiljī, and Haidar 'Alī. The view that'Alāu-d-dīn and Akbar 


\section{FOREWORD}

must have been able to read in order to govern, reminds us of Macaulay's criticism on Dr. Johnson's saying that " the Athenians were barbarians. The mass of every people must be barbarous where there is no printing." "Yes," says Macaulay, "an Athenian citizen might possess very few volumes, and the largest library to which he had access might be much less valuable than Johnson's bookcase at Bolt Court. But the Athenian might pass every morning in conversation with Socrates," etc., etc. Like Wordsworth's pedlar, Eastern prophets and kings had small need of books. It should be borne in mind too that in the East in those days there were no printed books. The only reading he had was from MSS. which were often in Shikast handwriting, and wanting in vowels and diacritical marks. Reading, therefore, was almost, if not quite, as difficult an attainment as that of writing, and unless 'Alāu-d-dīn and Akbar could read shorthand, which is really what Persian transcript amounts to, a knowledge of the alphabet and of the meaning of words would be of small help. The art of manuscript-reading is one of slow acquirement, and so we find that though Elphinstone could speak Persian, and admired Omar Khãyyām and other Persian poets, he could not read Persian MSS. and had to rely on his munshī or on a translation.

After the House of Khiljī comes the Tughlaq $\mathrm{xxi}$ 


\section{FOREWORD}

Dynasty. The enfant terrible of this line was $\mathrm{Mu}-$ hammad Tughlaq. He is the man who made Delhi a desert, and who put Ibn Batuta in fear of his life. Apparently this Tughlaq was partially insane. The glory of the dynasty was Fīrūz Shāh. He was, perhaps, the best of the Muhammadan emperors of India. He was more humane and less whimsical and revolutionary than Akbar, and more warm-hearted and human than Aurangzeb. And he had the advantage of a long reign, for he lived to a great age, and ruled nearly thirty years. He was not, perhaps, so clever as some other Emperors, but he loved his people, and was beloved by them. It is not too fanciful to hold that his happy nature was the result of the blending of two noble races, the Persian and the Indian. His father was named Rajab, and was Sipahsalar, or Commander-in-chief, and so held the office of which Abul Fazl gives such a glowing description in the $\bar{A}^{\prime}$ in (Jarrett's translation, p. 37), and his mother was the daughter of the Rānā of Dipalpur in the Punjab, and belonged to the Bhattì caste. Her name was originally Bībì Nā'îla, but it became Sulțān Bībī Kadbānū on her marriage to the Muhammadan Commander-in-chief. As a little girl, she showed her courage and spirit of self-sacrifice by offering herself as a ransom for her parents and her people, when they were being persecuted in order to win her as a bride for Sulțān 'Alāu-d-dīn's friend Rajab. Probably, as in the 


\section{FOREWORD}

Scottish case in the days of Protector Somerset, they thought to themselves that they liked the marriage, but not the fashion of the wooing. Mr. Law has in this part of his work done full justice to Fìrūz Shāh. At p. 55 he refers to Fīrūz Shāh's contrivance of a Țāsi-gharyāl, or water-clock. This really is the Clepsydra, of which Abul Fazl gives a description in vol. iii. of the $\overline{A^{\prime}}$ in (Jarrett, iii. I5). The historian Shams Sirāj claims that Fīrūz Shāh invented the water-clock, but this cannot be correct, for it was known to the Hindus at a much earlier period. (See Mr. Fleet's article in the F.R.A.S. for April last.) Nor does Fīrūz Shāh claim it as his invention in his Fatuhät. The translation of the Ṭāsi-gharyāl passage in Elliot, p. 338, is very brief. The Persian text, Bib. Ind. ed., p. 254, is much longer, but does not add to our knowledge of the machinery. Fìrūz Shah did not confine himself to the building of mosques and theological colleges. He also dug canals, and it was an incident of this work that the fossils of the Sivaliks were first discovered. It is said that Fìrūz Shah founded Jaunpūr (Elliot, iii. 307). It is also said that he called it Jaunānpūr after Jaunān, one of the names of Sulțān Muḥammad b. Tughlaq. But is it not more probable that Sulțān Muḥammad's name was Jūna or Jona? We find that Jüna was the name of the Tughlaq who transferred the capital from Delhi to Daulatābād. It is interesting, at all 


\section{FOREWORD}

events, that once or twice in the Haidarābād copy of Bābur's Memoirs, the name of the city is spelt Jūnagarh. (See also Imperial Gazetteer, xiv. 82, article "Jaunpūr.")

Chapter VIII. gives an account of the Minor Muslim kingdoms. Ferishta is chiefly followed here, and he is a good authority, for he long served in the Deccan. Jonathan Scott translated this part of Ferishta's history. Mr. Law pays a deserved tribute to the memory of the great statesman, Maḥmūd Gāwān. Unfortunately, Gāwān was put to death by his ungrateful master in I48I (Beale's Oriental Biography).

Book II. deals with the Mughal Dynasty. It is too late now to alter the phrase Mughal Dynasty, and after all it is not incorrect, for Bābur was at least half a Mughal by descent. But it would almost have made him turn in his grave to find the dynasty which he founded designated by the word "Mughal," for he hated the name and the tribes who bore it. Chapter I. contains an interesting account of this great prince. In the passage quoted at p. I22 from Mirzā Haidar, the phrase " his Holiness" means the great saint of Samarqand called Khwāja Aḥrār, and also Nașīru-d-dīn 'Ubaidullāh. $\mathrm{He}$ is likewise often designated by the phrase Hazrat İshān.

With reference to the remark at p. I24 about Bābur's saying that there were no Colleges in India, 


\section{FOREWORD}

it should be stated, in justice to him, that he is speaking of Madrasahs, i.e. Muhammadan Colleges, and that by Hindustan he means Upper India, which was the only part known to him. Thus limited, his statement is probably correct.

Bābur is commonly supposed to have spoken very contemptuously of the attractions of India, and there is a famous passage at p. 333 of Leyden and Erskine which begins with the remark, "Hindustan is a country that has few pleasures to recommend it." But it seems questionable if this translation of his words be correct. It all turns on whether the "word in the Turki be kam, "few," or kim, "which." The word certainly seems to be kam in the Gibb Trust and Ilminsky editions, but there is only a difference of two dots between kam and kim, and kim is Turkī, while kam is not. P. de Courteille, a thorough Turkī scholar, has read it kim, and translates, "Quoique l'Hindustan soit un pays naturellement plein de charme" (vol. iii. p. 226). The corresponding passage on the Haidarābād MSS. is at p. 290, second line from the top. If Erskine's translation be correct, it contradicts what he represents Bābur as saying some pages earlier, viz. 312, where we have the rendering, "It (India) is a remarkably fine country." Unfortunately, the word, both in the Turki and the Persian, in this passage is gharib, which means "strange and wonderful," rather than "fine," and M. 


\section{FOREWORD}

de Courteille's translation is, "C'est un pays tout 'a fait étrange." Personally, I am inclined to think that kim, "which," is right, and that Bäbur did not mean to abuse the country, but to distinguish it from the inhabitants. He disliked the latter because they did not like him, and their former king's mother had tried to poison him. But his persistence in refusing to quit India, as his ancestor Tīmūr had done, shows that he admired the country, and he vigorously defended its attractions when his old friend Khwāja Kilan abused it. His description, too, of India, and its beasts and birds shows how much he was impressed by its wonders.

Mr. Law's notice of Sher Shah is brief, but as full as is consistent with the purpose of the book. Sher Shah, as he himself lamented, only came by his own at evensong, and when his hair was grey. He was also prematurely slain. But in spite of his perfidies, and of his supplementing the lion's skin with the fox's, he was a great prince and much superior to his adversary, Humāyūn. He earned the enthusiastic praise of Badā'ūnī, who, in imitation of a saying of the Prophet, thanked God that he had been born in the reign of so just a king.

Mr. Law's account of Akbar is full and appreciative.

Jahāngīr (p. I74) deserves mention on account of his patronage of the lexicographer Jamālu-d-din xxvi 


\section{FOREWORD}

Husain Injīr, and of his attempt to have the Qur'ān translated into Persian (Memoirs, translation, II. p. 34).

Shāh Jahān deserves praise for the love of books which prompted him to make notes on MSS. It is to him that we are indebted for the preservation of Bābur's Divān. His love of music and song led him to be kind to even Armenian Christians.

Aurangzeb was a patron of Muhammadan learning and a great letter-writer, though such of his letters as I have seen are very uninteresting. His sister Jahān Ārā was an authoress, and wrote a tract about the Ajmere Saint, of which there is a copy in the British Museum. Aurangzeb's daughter Zebu-n-nisā was a poet, as well as an encourager of learning, and her Divān has lately attracted a good deal of attention.

In the chapter on female education (p. 202), a circumstance, which is worth mentioning in a book dealing with the promotion of learning, as showing Salīma's love of reading, is that Badā'unni apparently fell into disgrace because he, or somebody else, had lost a book which she had been studying (Lowe's Badä'ini, pp. I86 and 389). The book was either the original Thirty-two Thrones, or it was Badā'ūnīs own translation of it, to which he gave the name of the Khira$d \bar{a} f z \bar{a}$. It is the tales about a demon to which 


\section{FOREWORD}

Burton gave the title of Vikram and the Vampyre. We have again an early instance of an educated lady in Māh Malik, also called Jalālu-d-duniyāuuddin, the granddaughter of 'Alāu-d-dīn Jahānsoz. Minhāj, who was in a manner brought up by her, speaks of her with great admiration in his Tabaqät-i-Näsiriz, and says (vol. i. p. 392 of Raverty) that her handwriting was like royal pearls. Then there was Sulțān Rezia, in whom Ferishta finds that there was nothing wanting except that she was not a man. Minhāj makes the same remark, and adds that as her evil fate did not make her a man, all her talents were useless to her. Indeed, it seems that she, and Durgāvati of the Gond country, and Chānd Bìbì, and many others, were all born too soon.

Mr. Law is to be congratulated upon the successful accomplishment of a laborious and important task, which will be a substantial contribution to the history of India. The value of the book has been considerably heightened by the interesting illustrations which he has been at such pains to bring together from a variety of sources.

H. BEVERIDGE.

SHOTTERMILL,

I I May, I9I 5. 


\section{HINTS FOR TRANSLITERATION}

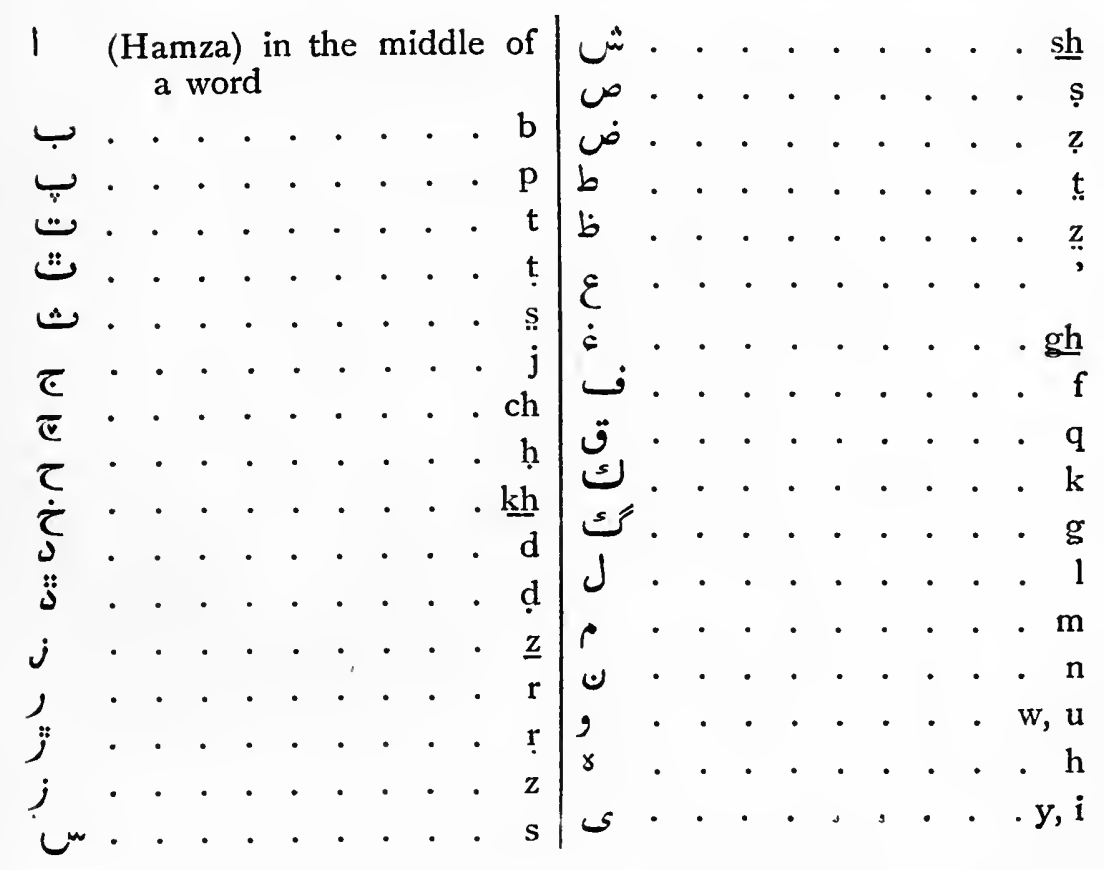





\section{TABLE OF ABBREVIATIONS}

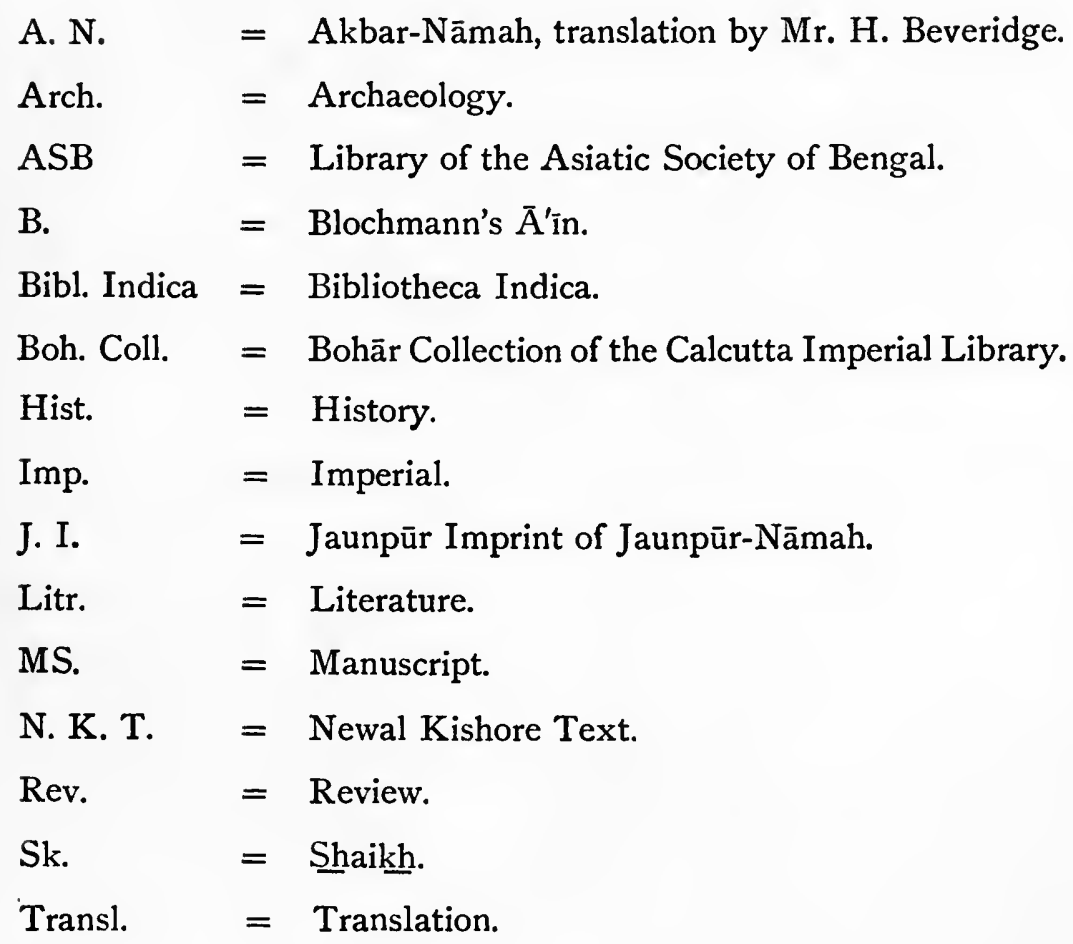


$\because$ 


\section{TABLE OF CONTENTS}

PAGE PREFACE . . . . . . . . . . . . . . . . . vii FOREWORD . . . . . . . . . . . . . . . xiii HINTS FOR TRANSLITERATION . . . . . . . . . xxix TABLE OF ABbREVIATIONS . . . . . . . . . . . xxxi BIBLIOGRAPHY . . . . . . . . . . . . . . xxxvii List OF Illustrations . . . . . . . . . . . . xliii Preliminary . . . . . . . . . . . . . . . $\mathrm{xlv}$

\section{BOOK I}

CHAPTER

I. The House of GhazNĩ :

Maḥmūd . . . . . . . . . . . . . 3

Mahmūd's Successors . . . . . . . . . I I

II. The House of GHūr . . . . . . . . . I7

III. The Slave Dynasty :

Quţb and his General . . . . . . . . . 19

Altamash . . . . . . . . . . . 20

Raziyah . . . . . . . . . . . . . . . $2 \mathrm{I}$

Nașīruddīn . . . . . . . . . . . . . 22

Balban and his Sons . . . . . . . . . 23

Kaiqubād • . • • • . • . . . . . . . 28 


\section{TABLE OF CONTENTS}

CHAPTER

PAGE

IV. The Khiljī Dynasty :

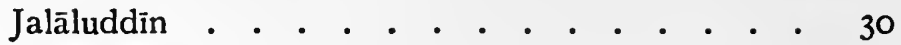

'Alāuddīn . . . . . . . . . . . . . . 32

V. The Tughlaq Dynasty:

Ghiyāṣuddīn . . . . . . . . . . . . . 42

Muhammad . . . . . . . . . . . . . 43

Fìrūz . . . . . . . . . . . . . . . . 47

Fīrūz's Successors and the Invasion of Tìmūr . 67

VI. The Sayyid Dynasty . . . . . . . . . 7 I

VII. The Lūdī Dynasty :

Bahlūl . . . . . . . . . . . . . . 72

Sikandar . . . . . . . . . . . . . . . 74

VIII. The Minor MUSLIM Kingdoms:

I. Bahmanī . . . . . . . . . . . . 80

2. Bījāpūr • • • • • • • • . • • . • . $9 I$

3. Aḥmadnagar . . . . . . . . . . . . 94

4. Gulkandah . . . . . . . . . . . 95

5. Mālwa . . . . . . . . . . . . . . 96

6. Khāndish . . . . . . . . . . . . . 98

7. Jaunpūr

8. Multān . . . . . . . . . . . . . . 105

9. Sindh, Kashmir and Gujrăt . . . . . . 105

Io. Bengal . . . . . . . . . . . . 106

RETROSPECT . • . • . • . . . . . . II4

\section{BOOK II}

THE MUGHAL PERIOD

I. The Mughal Dynasty:

I. Bābar • • • • • • • • • • • • • • • I2I

2. Humāyūn . . • . . . . . . . . . . 127

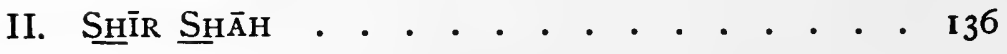




\section{TABLE OF CONTENTS}

CHAPTER

III. The Mughal Dynasty (contd.):

Akbar the Great . . . . . . . . . . 139

Māham Anaga, Akbar's Wet-nurse . . . . I65

Bairām Khān, Akbar's Guardian . . . . 169

Conclusion . . . . . . . . . . . . . 170

IV. The Mughal Dynasty (contd.):

I. Jahāngīr • • • • • • • • • • • • • 173

2. Shāh Jahān and Dārā Shikūh . . . . . I I80

3. Aurangzib . . . . . . . . . . . 187

V. The Mughal Dynasty (contd.) :

I. Bahādur Shāh . . . . . . . . . . . . 194

2. Muhammad Shāh and the Invasion of Nādir Shāh 196

3. Shăh 'Ālam II . . . . . . . . . . . . 198

Vi. Female Education . . . . . . . . . 200

Note on three pictures from Bankipore . after 206

ADDENDUM (ON THE QUESTION OF AKBAR'S IlliteraCy) 207

INDICES :

INDEX OF SUBJECTS . . . . . . . . . . . . 213

INDEX OF PROPER NAMES . . . . . . . . . . 237

Chronological IndeX . . . . . . . . . . 253 



\section{BIBLIOGRAPHY}

A

Abul Faẓl's Akbar-Nāmah, transl. by Mr. H. Beveridge.

'Afîf's Tārīkhi-Fìrūz-Shāhī.

Aḳhbārul-Akhyār, by 'Abdul Haqq Haqqĩ Dihlawī (lithographed edition).

'Ālamgīr-Nāmah, by Maulawī Munshīi Muhạammad Kāžim (Bibl. Indica).

Alberuni's India, by Sachau.

Archaeological Survey of India (new series), by Führer.

of Western India, by Burgess.

" " Reports, by Cunningham.

Āsārul-Șanādīd, by Sir Sayyid Amad.

'Ashiqqah, by Amir Khusrau.

Asiatic Annual Register.

Asiatic Researches.

'Azīzi-Dakhan, by Maulawī 'Abdul 'Āzīz.

B

Bādshhāh-Nāmah, by 'Abdul Ḥāmid Lāhaurī (Bibl. Indica).

Bernier's Travels-Constable's edition.

Blochmann and Jarrett's A'inni-Akbarī.

Brief Account of the Hist. and Antiquity of Lahore (Anonymous)

[in the Calcutta Imperial Library].

Briggs' Ferishta. Also Firishtah, N. K. T. 


\section{BIBLIOGRAPHY}

C

Caine's Picturesque India.

Calcutta Review.

Cartrou's Hist. of the Mughal Dynasty.

Conde's Arabs in Spain.

Dabistān.

Defremery's Voyages d'Ibn Bațūtah.

Dinesh Chandra Sen's Hist. of Bengali Literature.

Dorn's Makhzani-Afghānī.

E

Elliot's Hist. of India (as told by its own historians).

Elphinstone's Hist. of India.

Encyclopaedia Britannica (I I th ed.).

Erskine's Memoirs of Bābar.

\section{F}

Fanshawe's Delhi Past and Present.

Fergusson's Architecture at Bījāpūr.

Francklin's Shāh 'Ālam.

Futūhāati-Fìrūz-Shāhī, by Fīrūz-Shāh Tughlaq.

G

Garcin de Tassy's transl. of Tārīkhi-Shìr-Shāhī of 'Abbās Khhān. Gladwin's A'îni-Akbarî.

$\mathrm{H}$

Habibul-Siyar, by Khundamìr.

Hadiqatul-Aqālīm, by Murtazā Husain-MS. in ASB.

Havell's Handbook to Agra and the Taj, etc. 


\section{BIBLIOGRAPHY}

Hearn's Seven Cities of Delhi.

Hoey's Tārīkhi-Farḥ Bakhsh of Muhammad Faiz Bakhsh.

Hough's Christianity in India.

Huart's Hist. of Arabic Literature.

Humāyūn-Nāmah, by Gul-Badan Begam, transl.by Mrs. H. Beveridge.

I

'Ibrat-Nāmah, by Faqīir Muhammad.

Iquāl-Nāmah-i-Jahāngīiñ (Bibl. Indica).

Islāmic Libraries, by Justice Khudā Bakhsh Kh Kān.

$\mathrm{J}$

Jāmi'-Jahān-Numā, by Muzaffar Husain.

Jāmi'-ul-Tawārīkh, by Faqīr Muhammad.

Jauhar's Tazkaritul-Wāqi’āt.

Jaunpūr-Nāmah, by Khairuddīn Ilāhābādī-MS. in ASB. Also J. I. Journal Asiatique.

" of the Asiatic Society of Bengal.

J. Sarkar's Anecdotes of Aurangzib and Historical Essays.

" Hist. of Aurangzib.

" Topography of the Mughal Empire.

$\mathrm{K}$

Keene's Mediaeval India.

" Mughal Empire.

Khulāṣatul-Tawārīknh, MS. in ASB, by Sujan Rāi Khattrī.

Khurshīd-Jahān-Numāh, by Ilāhī Bakhshh-al-Ḥusainī.

L

Lanepoole's Aurangzib.

” Bābar.

Lethbridge's Topography of the Mughal Empire (transl. from the

Latin of Joannes de Laët).

L. F. Smith's Chahār Darwīsh. 


\section{BIBLIOGRAPHY}

M

Ma'āsiri-'Ālamgīīī, by Muhammad Sāqī Musta'id Khān (Bibl. Indica).

Ma'âsiriri-Rahịimī, by 'Ābdul Bāqī-MS. in ASB.

Malfūzāti-Tīmūrī, transl. by Stewart.

Malleson's Akbar.

Martin's Miniature Painting and Painters of Persia, India and Turkey.

Masālikul Abṣār fĩ Mamālikil Amșār of Shahābuddīn Abul 'Abbās Ahmat.

Meadows Taylor's Hist. of India.

Mir'āti-A humadī, by 'Alī Muḥammad Khhān.

Mir'ātul-'Álam, by Bukhtawar Khān-MS. in the Bohār Collection of the Calcutta Imp. Library.

Muntakhabul-Lubāb, by Khāfī Khān (Bibl. Indica).

Muntakhabul Mir'àtul-'Ālam-MS. in Boh. Coll.

Muntakhab-Ṭabaqāti-Akbarī-MS. in Boh. Coll.

Muntakhabul-Tawārikhh, vol. i (Ranking).

Murray's Discoveries and Travels in Asia.

\section{$\mathrm{N}$}

Navya Bhârata.

Nineteenth Century.

Noer's Akbar, transl. by Annette S. Beveridge.

Nuh-Sipihr of Amir Khusrau.

Pinkerton's Collection of Voyages.

Pogson's Jaunpūr.

Purchas His Pilgrims.

Q

Qānūni-Islām, by Ja'far Shharīf. 


\section{BIBLIOGRAPHY}

$\mathrm{R}$

Rait's Life in the Mediaeval University.

Rauzatul-Ṣafă, by Mïrkhund.

Ravenshaw's Gour.

R. H. Major's India in the $15^{\text {th }}$ Century.

Riyāẓul-Salātīin, transl. by 'Abdul Salām (Bibl. Indica).

S

Shhāh-Jahān-Nāmah, by Muhammad Amīn Qazwīnī-MS. in ASB.

Shoberl's Hindustan in Miniature.

Short Hist. of the Saracens, by Justice Amir 'Ali.

Siyarul-Mutaakhkhirīn, by Ghùlām Ḥusain.

Sleeman's Rambles and Recollections.

Smith's Architecture at Fatḥpūr Sīkrī.

Asoka.

Stephen's Archaeology of Delhi.

Stewart's Hist. of Bengal.

Storia do Mogor, by Niccolao Manucci.

\section{$T$}

T: abaqāti-Akbarī, by Nizāmuddin Ahmmad-MS. in ASB.

Tabaqāti-Akbar-Shāhī-MS. in Boh. Coll.

Tabaqāti-Nāșirī, by Minhājus Sirāj, transl. by Major Raverty.

Tabṣīâtul-Nāżirīn, by Sayyid Muhammad Bilgrāmī-MS. in ASB.

Tafrīhul-'Imārāt, by Sīlchānd-MS. in ASB.

Tājul-Ma'âșir, by Ḥasan Nizāmì.

Talbot's Memoirs of Bābar.

Târikhi-Akbarī-MS. in ASB.

Tārīkhi-Dā'ūdī, by 'Abdullāh.

Tārìkhi-Fārrukhāābāīi, by Muhammad Waliullāh-MS. in ASB.

Tārìkhi-Fìrūz-Shhāhī, by Ziyāuddīn Barnī (Bibl. Indica).

Tārīkhi-Guzīdah, by Hamdullah Muṣtaufĩ.

Tārīkhi-Jān-Jahān, by Jān Jahān Khān-MS. in ASB. 


\section{BIBLIOGRAPHY}

Tārīkhi-Jahān-Kushēā, by 'Alāuddīn Jawainī.

Tārīkhi-Kashmīr, by Muḥammad Aslam-MS. in ASB.

Tārīkhi-Manșūr, by Sayyid 'Alī Ḥusainī-i-Bilgrāmī-MS. in ASB.

Tārīkhi-Mubārak-Shhāhī.

Tārīkhi-Muzaffarī, by Muḥammad 'Alī Khāan Anșārī-MS. in ASB.

Tārìkhi-Nizāmī-MS. in ASB.

Tārīkhi-Qandhāri-Dakhan, by Munshī Muhammad Amīr Hamzah.

Tārikhi-Rashidī, transl. by E. D. Ross and N. Elias.

Tārikhi-Salāțini-Afāghinah, by Aḥmad Yādgār-MS. in ASB.

Tärīkhi-Shīir-Shāhī, by 'Abbās Khān.

Tārỉkhi-Wașșāf, by 'Abdullāh Wașșāf.

Taylor's Memoirs.

Tazkkiratul-Salātịn-MS. in Boh. Coll.

Tazkkiratul-'Ulamā, by Khairuddīn Ilāhābādī-MS. in ASB.

T. Bacon's Oriental Annual (1840).

Thevenot's Travels into the Levant.

Thomas's Chronicles of the Pathān Kings of Delhi.

Tuhfatul-Salātīin, by Mullā Dā'ūd Bīdarī.

Tūzaki-Bābarī.

Tūzaki-Jahāngīīi, transl. by Lowe (Bibl. Indica).

"

" by Rogers and Beveridge.

W

Wāqīāti-Jahāngīrī (Elliot).

" " transl. by Price.

Wāqī'āti-Mushtāqī, by Rizqullah Mushtāqui.

Willard's Treatise on Hindu Music.

Z

Zafar-Nāmah, by Yazdī-MS. in Boh. Coll.

Zubdatul-Tawārīkh, by 'Abdul Karìm. 


\section{LIST OF ILLUSTRATIONS}

Madrasah OF MAHMū̃d GĀWĀN at BĨdAR, built I479 FACING PAGE A.D. . . . . . . . . . . . . . Frontispiece

AsoKa PILlaR, transported by Fīrūz Shāh Tughlaq from Khiz̨rābād to Delhi . . . . . . . . . . . . 52

PIR GAIB, identified as the Kūshki-Shikār (Hunting Palace) of Fìrūz Shāh Tughlaq, where one of the Asoka Pillars was placed by the Emperor . . . . . . . . . 54

QADAM SHARIF (Holy Footprint): the tomb of Fath

Khān, son of Fīrūz Shāh Tughlaq, with a dependent Madrasah . . . . . . . . . . . . . 59

Another View of Qadam Sharif . . . . . . . . 60

FīRŨZ SHĀH TUGHLAQ'S TOMB, to which a Madrasah was attached . . . . . . . . . . . . . 66

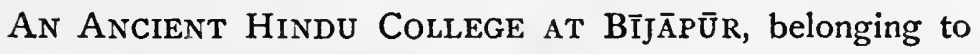
the Twelfth Century A.D. . . . . . . . . . . . 92

ĀșĀRI-MUBĀRAK, containing the 'Ādil Shhāhī Library • . . 94

ChahĀR MinĀR at HaidarĀBĀD, containing a Madrasah, built I59I A.D. . • • • • • • • • • • • • • . 95

KĀṬRĀ MADRASAH (MURShIDĀBĀD), built by Ja'far Khān . II 2

Domestic System of Teaching among the MuhamMadans. A Teacher with his Pupils. By Bihzād, the famous Persian Painter . . . . . . . . . . . II7

A Teacher with his Pupils, by Bihzād . . . . . . 118 xliii 


\section{LIST OF ILLUSTRATIONS}

FACING PAGE

Teachers and their Pupils, by Bihzād . . . . . . . I I 8 HumĀyūn's Library . . . . . . . . . . . . I33

HUMĀYŪN'S TOMB, which housed a Madrasah . . . . . I 34

MAdRasah of MĀHam ANaga (Akbar's Wet-nurse) . . . 166

A Library at Hulwān in Persia. A person reading a book to an attentive audience . . . . . . . . . I70

NAWĀB GHĀZīudDīn's MadraSaH . . . . . . . 194

NAWĀB GHĀZĩudīn's TOMB, to which his Madrasah is attached . . . . . . . . . . . . . . . . 194

JANTAR MANTAR-the Observatory at Delhi, built by Jai Singh at the instance of Muḥammad Shāh . . . . . 196

MASJID OF NAWĀB SHARAFUdDAULAH with attached Madrasah at Shāhjahānābãd . . . . . . . . . . 197

PlaN OF Girls' School in Akbar's Palace at Fatḥpūr Sìkrī 202

A Mughal Princess having her Lesson. . . . . . 206

A Group of Muhammadan SaInts and Maulawīs, probably of Shāh Jahān's time . . . . . . . . 206

Illustration OF THE STORY OF HaQİQAT RĀI OF LAHORE . . . . . . . . . . . . . 206 


\section{PRELIMINARY}

ThE Muhammadan invasions of India marked the beginnings of momentous changes not only in the social and political spheres but also in the domain of education and learning. No longer did the air resound exclusively with the chanting of the Vedic hymns or the recitation of the Buddhist scriptures, but side by side with these, and sometimes in supersession of these, were heard the $\bar{A}$ yats of the Qur'an and the Hadiss of the Prophet. The settlement in India of a foreign nation with its own ideals and culture developed by evolution through centuries, and their acquisition of political supremacy in the land, naturally placed indigenous ideals and culture at a disadvantage. And so the indigenous system of education was for a time deprived of the stimulus and support of state or royal patronage which now applied itself to the promotion of the new Islāmic learning, the old learning being left to shift for itself and thrown upon the resources of popular support. Sometimes, it was even put down and persecuted by the political power flushed with $\mathrm{xlv}$ 


\section{PRELIMINARY}

its first victories, and we have harrowing tales of old Universities broken up, libraries looted and the votaries of indigenous learning, Hindu or Buddhist, murdered or driven away homeless. These were, however, the days of unrest and transition, of the travails of a new birth when the old order was changing, yielding place to new.

The day was yet distant when we should find the Muhammadan rulers patronizing the education of their Hindu and Muslim subjects alike and encouraging with equal ardour the growth of other learning besides the Muhammadan ; but for about a century or two after the first Muhammadan conqueror had set foot on Indian soil, Hindu education and literature followed their own independent course supported by their own votaries.

It goes without saying that in these early days, the personal character of the reigning sovereign was the most important factor affecting popular wellbeing, and it was specially true in the case of education. If the Emperor were of literary tastes and encouraged the cause of education and learning, we find his Court a bee-hive of literary men, poets, philosophers and scientists, giving a great impetus to the literary life of the day. We find noblemen imitating him and lavishing endowment after endowment upon schools, colleges and distinguished literary men, for their support and xlvi 


\section{PRELIMINARY}

encouragement. On the other hand, if the Emperor were devoid of literary tastes and addicted to low pleasures and licentiousness, there was a corresponding set-back in learning. We find his Court deserted by the literati, and learning languished as a rule. The reason for this is not far to seek. The sovereign was the largest fountain from which the educational institutions, professors and literary men drew a very large portion of their sustenance, a slight change in his literary taste producing a corresponding change in the literary world. Centralized as all power was in the Emperor alone, the changes in his will and desire made themselves felt in all directions of national activity: the Emperor's taste was, so to speak, a barometer of the then literary atmosphere. We find, however, in the case of 'Alāuddin Khilji, that the literary life of the day was in a vigorous state though the Emperor had no literary taste and even did positive harm to the cause of learning in the beginning of his reign by confiscating the endowments that fed the literary institutions and learned men. Such a state of things is surely abnormal, which we cannot explain unless we bear in mind that private munificence played not a small part in the sustenance of learning. So if literary life appeared to flourish in spite of the Emperor in the early part of his reign, it was owing to the momentum it had already acquired, and the encouragement it obtained xlvii 


\section{PRELIMINARY}

from private individuals, landholders and petty chiefs. State encouragement is vital to the literary and educational advance of the country, and in the days when the Emperor himself was virtually the State, we can realize the important rôle played by him for good or evil in the literary world. It is when we look at the matter from this standpoint that we understand the importance of carefully observing the literary tastes, education and other such traits in the character of the long roll of Muhammadan Invaders and Emperors who came to influence the destiny of India. 


\section{BOOK I.}

THE PRE-MUGHAL PERIOD. 
$\because$ 


\section{CHAPTER I. \\ The House of Ghazni.}

WE shall begin with Sulțān Mạ̣mūd and review seriatim the work of Muhammadan sovereigns, noticing at the same time all relevant facts bearing on the educational and literary history of the period.

Sulțān Maḥmūd, notorious as an iconoclast, had one great redeeming feature in his character. $\mathrm{He}$ was a great patron of learning and a staunch friend of learned men. But a bigoted Musalmān as he was, he did not care to encourage the learned men of any other faith, or to foster the education of the people of any other persuasion.

It need hardly be pointed out that it was at his capital at Ghazni that he showered the largest portion of his munificence; and so to the Hindus, the darker aspects of his character were better known than the brighter. The name of Mahmūd has become with them a synonym for bigotry, cruelty and rapacity combined. A Hindu who hears of his seventeen successive invasions of India, of his destruction of Hindu temples and images of gods and goddesses, of the numberless 
people he massacred and put to cruel death; of the havoc and horror he created and of his plunders and devastations, does naturally paint him in the blackest dye. In justice, however, to this Sultān some of the redeeming qualities of his head and heart should be properly and adequately emphasized.

The following anecdote related by Hamdullah Muștaufī, the author of the Tärikhi-Guzidah, is very suggestive :

"Mahmūd's features were very ugly. One day regarding his own face in a mirror, he became thoughtful and depressed. His Wazir enquired as to the cause of his sorrow, to which he replied, 'It is generally understood that the sight of kings adds vigour to the eye, but the form with which I am endowed is enough to strike the beholder blind.' The Wazir replied, 'Scarcely one man in a million looks on your face, but the qualities of your mind shed their influence on every one.'" 1

To make an impartial estimate of Mahmūd's qualities, it is necessary to describe these "qualities of mind" which are less known than the sterner aspects of his character.

Mahmund's large-hearted munificence for the encouragement of learning is well worthy of record. The Guzidah ${ }^{2}$ mentions that annually he bestowed upon learned men and poets the princely sum of 400,000 dinärs. But his zeal for education was not confined to the mere support of learned men :

${ }^{1}$ Elliot iii, p. 63.

2 Ibid., iii, p. 63. 


\section{THE HOUSE OF GHAZNI}

it also founded institutions for the permanent promotion of learning. In the neighbourhood of the magnificent mosque of marble and granite, richly furnished with carpets and candelabra, and ornaments of gold and silver,-the mosque which received the endearing appellation of Celestial Bride-

"was founded a University supplied with a vast collection of curious books in various languages. It contained also a museum of natural curiosities. For the maintenance of this establishment, he appropriated a large sum of money besides a sufficient fund for the maintenance of the students and proper persons to instruct youths in the arts and sciences." 1

Ferishta, moreover, adds the interesting piece of information that 'Unșuri, the scholar who was profound as a scientist, well-versed in all the learned languages, great as a philosopher, and as a wit and a poet, the greatest of his age-the man who acted to Mahmūd as a censor of literature, was appointed as a professor of the University of Ghaznī. His versatile talents no doubt made him quite fit for the post which he was selected to adorn.

The establishment of this University and the encouragement of belles lettres and learned men was somewhat of an expiation for the ill-gotten hoard of wealth acquired by plunder and bloodshed. Within a short time, the city of Ghazni became an attractive resort of literary men, poets, philosophers

1 Briggs' Ferishta vol. i, p. 6I. 


\section{PROMOTION OF LEARNING}

and scientists, which made it a most renowned centre of learning, as it was at the same time fast becoming a great civic centre adorned with beautiful works of architecture and sculpture, with public buildings and private palaces, with mosques, porches, fountains, aqueducts, baths and reservoirs. The city rose to be as famous as a Bologna or a Padua of Mediaval Europe. Of the many learned men of genius and eminence who shared the munificence of the Sulțān, one was 'Utbi who composed the Tärikhi-Yamini, which was an account of the descendants of Subuktigīn. Another was 'Uzeerī Rāzì, a native of Persia, who on one occasion received a present of 14,000 dirhams from the Sulțān for a short panegyric. Asadì Țūsī, a native of Khurāsān and a poet of great fame, was the master of Firdausī. The Sulțān often requested him to undertake the $\underline{S h} \bar{a} h-N \bar{a} m a h$, but he excused himself on the ground of his old age. However, when Firdausī fled from Ghazni, he

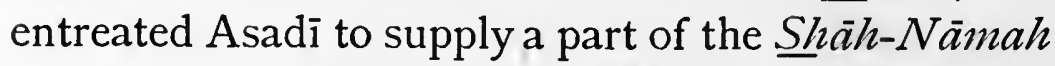
consisting of 4000 couplets. Munuchihr, a noble of Balkh, was also famous for his wit and poetry, and lived at the royal court.' 'Unșuri, the greatest poet of his age, a great philosopher, scientist and linguist, whom we have already mentioned in connection with the University of Ghaznī, was a great panegyrist of Mahmūd, writing quite a crop of odes and

${ }^{1}$ Ferishta vol. i, pp. 89 ff. 


\section{THE HOUSE OF GHAZNI}

quatrains in his praise. A curious story relates that the Sulțān-

" having one night in a debauch cut off the long tresses of his favourite mistress, was much concerned in the morning for what he had done. He sat, he rose, he walked by turns, and his attendants were alarmed to approach him. The philosopher 'Unsuri accosted him with some extempore lines which so pleased the king that he ordered his mouth to be thrice filled with jervels. Calling then for wine, he sat with the poet and washed down his grief." 1

'Unșurī was appointed by the Sulțān to superintend literature, and no work could be brought before Mahimūd without his approval. Four hundred poets and learned men as also the students of the University of Ghazni acknowledged him as their master who was invested with the recently created dignity of a poet-laureate, able by his verdict to open the way to royal favour for rising talents. ${ }^{2}$ Așjudi, who was a powerful poet and a pupil of 'Unșurī, composed a Qașîdah lauding the virtues of his patron on the occasion of the sacking of Somnāth, as also Farrukhī, another pupil of 'Unșuri who amassed great wealth through the generosity of the monarch, of which he was deprived by robbers on his way to Samarqand, were also of the number of learned men patronized by him. Nor must I omit to mention in this connection the name of the famous poet who has been the subject of an anecdote that has been iterated, times out

1 Ferishta vol. i, p. 9 I.

2 Preface to Alberuni's India, by Sachau, p. I. 
of number, by historians to exemplify Maḥmūd's literary ardour. I mean the author of the ShathNammah,- the immortal Firdausi, who was attracted to Mahmūd's court by the fame of his liberality and charged by the Sultān with the difficult task of completing the historical poem left unfinished by Daqiqi whose life was cut short by a servant. The death of Firdausī, as well as his appointment by Mahmūd, took place in an equally curious way, which may well repay a detailed narration ${ }^{1-}$

"It is written in the books of the learned authors that during the first years, Firdausi took great pleasure in versification. It happened one day that he received ill-treatment from somebody and went to Ghaznī to lodge his complaint to Sultān Mahmūd. On arriving near the city, he saw three men conversing together in a garden and the poet talked with them, hoping they would help him in the matter for which he came. The men said that they were the Sultān's poets and that they did not talk with anybody who was not a poet-(the three men being 'Unșurī, Așjudī and Farrukhi) and took into their society only that man who could add a fourth verse to the three verses they would recite."

When Firdausi heard this, he consented to supply the complementary verse, and the readiness with which he did so, astonished the poetic trio and made him one of them. He achieved his immediate object, and was introduced to the Sulțān whose discerning eye did not fail to appreciate the merits of the poet. Having afterwards been appointed to compose the Shăh-Namah, he wrote a thousand

1 Vide Habibul-Siyar of Khundamir, Elliot iv, $188 \mathrm{ff}$, and Ferishta vol. i, pp. 89 ff. 


\section{THE HOUSE OF GHAZNI}

verses for which the Sulțān gave him rooo dinārs, Ghazni. when they were shown to him for approval. When Firdausi finished the poem, the verses amounted to 60,000, and he expected to get a dinär for each verse. The Sulțān, however, on the advice of a few persons of mean disposition sanctioned only 60,000 dirhams to be given to Firdausi as his remuneration. This amount was brought to the poet when he was just coming out of a bath. He was so much disappointed at the reward which fell so short of his ambition that he gave a third of the sum to the bath-keeper, another third to a sherbet-seller who had brought him some beverage, and the rest to the person who brought the money.

Firdausi was stung to the quick by the Sulțān's injustice, which dashed all his hopes, and a literary man as he was, he avenged this wrong in a literary way. He composed about 40 verses which hurled a biting satire at the Sultān, incorporated them into the $\underline{S h} \bar{a} h-N \bar{a} m a h$, and fled to Tius, his native city, to be out of reach of the power he attacked. One day, some time after this incident, Ahmad bin Hasan Maimandi, who was also one of the poets who enjoyed the Sultān's patronage, was out ahunting with the Sultān, and having come close, repeated several verses out of the Shäh-Nāmah, which were exceedingly applauded. Being asked by Maḥmūd whose poetry it was, Hasan answered that it was composed by Firdausi. The Sultān 


\section{PROMOTION OF LEARNING}

repented of his neglect of the incomparable poet and ordered his men to take 60,000 dinàrs at once to Tius and ask the poet's pardon. In the Bahäristān it is written that when these presents came in at one gate of TTùs, the coffin of Firdausi was carried out at the other. An only daughter was his heiress. She refused to accept the presents when offered to her, saying-

"I have enough wealth to last me to the end of my days. I have no need of this money."

The daughter's answer was indeed well worthy of the high-souled father. ${ }^{1}$ The Sultān built a caravansarai with that money in the neighbourhood of Tùs, characteristically loath to appropriate for himself the sum once given away as reward to a deserving man, and anxious to apply it to the original purpose cy près.

Magnanimous towards literary men as he was, his literary bias dominated on one occasion his martial instincts and made his zeal for war yield to dictates of peace; in I023 A.D., he invested the fort of Gwalior, and after a while Nanda Roy, its chief, willing to conclude peace, sent out 300 elephants without riders, for the Turks to seize and take them. $^{2} \quad$ Ferishta has a somewhat different version of this event and says that Nanda had intoxicated the elephants with drugs in order to put the bravery

1 Vide Habibul-Siyar of Khundamīr, Elliot iv, pp. $190 \mathrm{ff}$.

2 Tabaqāti-Akbari, Elliot ii, p. 467. 


\section{THE HOUSE OF GHAZNI}

of the Sultān's troops to the test, and also adds that along with these presents, which were surely of doubtful benefit to the Sultān if they were actually in the state mentioned by Ferishta, were offered a few other presents also. ${ }^{1}$ Whichever account be true, it appears that the Sultān could not have been propitiated, had it not been for a complimentary poem sent to him at the time. Its poetry was so much admired by the learned men of India, Arabia and Persia attached to his Court, and Mahmūd was so much pleased with it that in return he conferred on Nanda the government of 15 forts, among which was the strong fort of Kālañjar. This was indeed a rare example in all history, of the triumph of poetry and literature, the victory of idealism, and it speaks volumes in favour of the man through whom this triumph and this victory were achieved.

We have thus seen that Mahmūd, who is popularly known for his militarism and plunder, was also a great patron of Muhammadan learning and, indeed, in the words of our historian Ferishta, " no. king had ever more learned men at his Court" 2 than Sulțān Maḥmūd.

Mahmmūd also bequeathed to his successors his own zeal for education. The House of Ghazni throughout maintained its reputation for its

1 Ferishta vol. i, pp. 66, 67.

2 Ibid., p. 32. 
patronage of learning. The successor of Sultān Maḥmūd was

"generous to prodigality particularly to learned men, of whose company he was so fond that many were induced to come from all parts to his Court. Among the most celebrated, we must reckon Anwar Khān Khwārizmī, a great philosopher and astronomer who wrote an excellent treatise upon astronomy called Mas'üdi, in reward for which he was presented with an elephant's load of silver. Abū Muhammad Nasāhī was a man of eminent learning in his age ; he wrote a book entitled also Mas'îdi, in support of the doctrine of $A b \bar{u}$ Hanifah, which he presented to the king. In the beginning of his reign, Mas'üd built many mosques, and endowed several colleges and schools which he caused to be erected in the different cities of his dominions." 1

In Mas'ūd we find a worthy successor of Mahmūd, maintaining the traditions of his father, erecting magnificent public buildings including schools and colleges, making provision for their maintenance by rich and adequate endowments, keeping up the attractiveness of $\underline{G}$ hazni $\overline{1}$ for learned men, paying particular attention to diffusion of learning, and placing its benefits within the easy reach of the general public by establishing educational institutions in the several cities of his large dominions. Mirkhund, the author of the Rauzatul-Saf $\bar{a}$, informs us that he was very fond of the company of the learned, whom he obliged in manifold ways; for which, many an author dedicated to him his book. "During his reign," on the evidence of the same authority, "so many

1 Ferishta vol. i, pp. II3, I 44. 


\section{THE HOUSE OF GHAZNI}

colleges, mosques and religious edifices were built in the various parts of his dominions that it is impossible to enumerate them." 1 For the unstinted liberality of this Sultạn towards the learned and the cause of learning, we have the testimony of the famous savant Alberuni who flourished at this time. He could not rise in the good graces of Sultān Mahmūd most probably for the political antagonism that existed between him and Mahmūd's chancellor Maimandī. And so, like Firdausī, he took a literary man's mild revenge upon the Sulțān by accusing him of "having failed in the duties of a protector of art and science imposed upon him by his royal office," and by lavishing his praise upon his successor, in whose régime he could obtain his full share of royal protection and encouragement. ${ }^{2}$

From the writings of Alberuni, we can get an insight into the rapid progress that Arabic and Persian literatures were then making in laying under contribution the rich store of knowledge imbedded in both Sanskrit literature and Greek. Indian mathematics and astronomy, astrology, philosophy, medicine and pharmacology were favourite subjects of study with the Muhammadan scholars, and translations of Indian works including a large portion of narrative literature into Arabic

1 Rauzatul-Ṣafā by Mīkhund, Elliot iv, pp. 138, 139.

2 Vide Preface to Alberuni's India by Sachau. 


\section{PROMOTION OF LEARNING}

and Persian were fast being made by these energetic and inquisitive students. ${ }^{1}$

The next four Sultāns who came successively after Mas'üd to sit on the throne of Ghaznī were not noted for their literary zeal. Ferishta on the authority of the Jamiul-Hikayyat informs us that Sulțān Ibrāhìm who came after them was of a religious disposition and used to hear lectures regularly on his favourite subjects of religion and morality from Imām Yūsuf Sajāwandī; and on such occasions, he showed, in a remarkable degree, patience and resignation with which he used to bear the reproofs of his moral tutor. He was not certainly a sovereign in the eye of the guardian of his moral self, and both the pupil and the preceptor acted accordingly.

This Sultān excelled in the art of fine writing cultivated in the East by the Muhammadan Emperors as a separate subject of study requiring particular attention, and like many a Musalmān monarch before and after him, sent two copies of the Qur'an which he had transcribed with his own hand during his leisure hours to Mecca and Medina as presents to the Caliph to be deposited in their respective sacred libraries. ${ }^{2}$

The next Sulțān, Bairām bin Mas'ūd, was possessed of an uncommon thirst for knowledge.

1 Vide Preface to Alberuni's India by Sachau.

2 Ferishta vol. i, p. 137. 


\section{THE HOUSE OF GHAZNI}

He infused new blood into the literary world by his ardent promotion of literature, and liberal and openhanded patronage of learned men. Of the many literary men who flocked to his Court, the names of Shaikh Nizāmī and Sayyid Hasan Ghaznawì (the former being the author of the Makhzani-Āsär dedicated to the Sulțān his patron and both of them being poets and philosophers of widespread fame), are worthy of note. The Sulțān caused several works in foreign languages to be translated into Persian, among which was the Indian book KalilahDamnah. ${ }^{1}$ This work along with a chess-board had been sent as a present by an Indian king to Naushinrawān, the Persian monarch, by whose wazìr Buzurchimihr it was translated into Pahlawi from the Sanskrit original. It was afterwards rendered into Arabic by Ibn-ul-Muqliyã in the reign of the famous king Hārūn-al-Rashīd; it was from this Arabic version that Sultān Bairām ordered it to be translated into Persian. The work was accomplished, but it bristled with Arabic words and was full of Arabic poetry for which it had to undergo a subsequent transformation at the hands of Maulānā Husain Wā'iz Kāshifí in the reign of Sulțān Husain Mìrzā Khwārizmī, and it then got the new title of Anwari-Suhaili. ${ }^{2}$

1 An adaptation of the Indian tales of the Panchatantra.

2 (For the whole para.) vide Ferishta vol. i, pp. I49, I50, and C. Huart's History of Arabic Literature, p. 2 I I. 
We have now done with the House of Ghazni, which, as we have seen, counted among its members several Sulțāns having marked literary predilections and applying the resources of the state to the promotion of learning. 


\section{CHAPTER II. \\ The House OF GHür.}

WE now reach the period of the House of Ghür, under which learning did not fare so well as it did under the House of Ghazni. The first chapter of Ghūrī history is associated with the vandalism of 'Alāuddin Ghūrī, under whose orders, the city of Ghazni, perhaps the noblest and the most beautiful in the whole of Asia at the time-

"was given up for three, and some say seven, days to flame, slaughter and devastation. All the superb monuments of the Ghaznevite kings were demolished and every trace of them effaced, except the tombs of Mahmūd, Mas'ūd and Ibrāhīm; the first two of whom were spared for their valour and the last probably for his sanctity." 1

The real founder, however, of Ghūrī greatness was Muhammad Ghūrī, better known for his conquests which surpassed those of Sulțān Mahmūd than for his devotion to letters. In the interim of more than half a century, we have a period of chronic war and unrest, and so far as literary matters are concerned, it might be called a very dark epoch. But as unrest was gradually settling down, we find Muhammad turning his thoughts towards the literary progress of his

1 Elphinstone (9th ed.) pp. 348, 349. 
dominions; but it should be remembered that these efforts were all marked by a religious exclusiveness which looked to the progress of the Muslim subjects alone. While he was at Ajmere, Muhammad Ghūrī, it is related by Hasan Niz̄āmī, ${ }^{1}$ "destroyed the pillars and foundations of the idol temples and built in their stead mosques and colleges, and the precepts of Islām and the customs of the Law were divulged and established."

In his zeal for conquests and the spread of Islām, in the hurry and bustle of battles and the consequent mental preoccupations, he did not forget his duty towards the peaceful cause of education.

Besides his work at Ajmere, Ferishta records his work of private tuition undertaken in respect of some of his Turkey slaves. Says he:

"Muhammad Ghūrì having no children except one daughter, took pleasure in educating Turkey slaves whom he afterwards adopted. Four of these slaves besides Qutbuddin became great princes, of whom Tājuddīn Yaldūz was one." ${ }^{2}$

Three of these were in possession of extensive governments at the time of Muhammad's death : Quṭbuddīn in India, Yaldūz in Ghaznī, and Nașīruddīn Qubāchah in Multān and Sindh. ${ }^{3}$ It appears that in the instruction of these protégés of his, he used to combine a literary education with a training in the difficult art of practical government, which was essential to princes.

1 Tăjul-Ma'āsir by Hasan Nizāmī, Elliot ii, p. 215.

2 Ferishta vol̈. i, p. 200.

3 Elphinstone, p. 360. 


\section{CHAPTER III. \\ The Slave Dynasty.}

THE House of Ghūr was succeeded by the Slave Dynasty. Its founder Qutbuddin received his early education in a school at Nishāpūr where he became proficient in Persian and Arabic, and acquired also some knowledge of science. ${ }^{1}$ When he came to power in India, he was already known for his literary tastes and scholarship. Muhammadan learning was promoted by the establishment of hundreds of mosques which like the churches of Mediæval Europe were centres of both religion and learning. But Quthb set the unhappy example of destroying Hindu temples and raising mosques on their foundations, which was so ruthlessly followed by his Lieutenant Bakhtiyār Khiljī. ${ }^{2}$

The destructive work of Bakhtiyār with its tragic details throws some light on the state of indigenous learning which was being jeopardized by the alien power. The first object of attack was the monastic university at Biharr which was then teeming with Buddhist students and monks, and

1 Ferishta vol. i, pp. 189, 190.

${ }_{2}$ Täjub-Ma'àsir by Hasan Nizāmī, Elliot ii, pp. 222, 223. 
was well-equipped with libraries. ${ }^{1}$ The atrocities of Bakhtiyār did not leave a single scholar alive. The massacres at Bihār were followed by the destruction of Nadiya which was then both the political and intellectual capital of Bengal. Bakhtiyār then made partial amends for his destructive work by his construction of mosques, colleges and monasteries in the different parts of the country for the spread of Muhammadan learning. ${ }^{2}$

The next king Altamash with his political preoccupations does not seem to have given much thought to the encouragement of learning. There are, however, proofs that he was liberal ${ }^{3}$ and that Delhi continued to be the resort of learned men. There sought refuge the most learned Persian poet and philosopher of his age, Amīr Kühān̄ī, ${ }^{4}$ who fled from Bukhārā when it was sacked by Changīz Khān to the court of Delhi, which was sufficiently attractive to draw him thither for asylum and protection; and during his stay there, he wrote a great many poems. Again, Nașiruddin, the author of the popular collection of historical anecdotes in Persian, lived at the Sulțān's court,

1 Raverty's Tabaqāti-Nāșirī by Minhājus Sirāj, p. 552; TabaqātiAkbarī MS. in ASB by Nizēāmuddīn Aḥmad, p. 46; TārīkhiManșūrī, MS. in ASB by Sayyid 'Alī Husainī-i-Bilgirāmī, p. 96.

2 Tabaqāti-Nāṣiri by Minhājus Sirāj, Elliot ii, pp. 306-309 ; Raverty, pp. 559, 560.

3 Vide Raverty's TTabagāti-Näșiri, p. 588.

4 Ferishta vol. i, p. 210. 


\section{THE SLAVE DYNASTY}

receiving his encouragement and patronage. ${ }^{1}$ Moreover, the choice of Fakhr-ul-Mulk, formerly wazir of the Caliph of Baghdād for 30 years and much renowned for his wisdom and learning, as the Sultān's prime minister shows that Altamash had a discerning eye and was not slow to recognize literary merit. We further learn that a madrasah was built by this monarch and that this edifice fell into a dilapidated condition in the time of Sultān Fìrūz Tughlaq more than a century afterwards; and Fìrūz, with his characteristic liberality shown in educational matters, rebuilt the college and furnished it with sandal-wood doors. ${ }^{2}$ Lastly, Altamash faithfully discharged the duty of giving a sound education to his son Mahmūd, for whom a separate arrangement was made at Loni befitting his position.

Sultānah Raziyah, the gifted daughter of Altamash, on whom devolved the difficult task of government and who fills a high place in the illustrious roll of Indian women-rulers, owed her success, in no small degree, to her education. Ferishta records that she was well-versed in the Qur'an, which she could read with correct

1 Nūruddīn Muhammad 'Ufi was the full name of the authorFerishta vol. i, p. 212.

2 Futūhāâti-Fīrūz-Shāhī, Elliot iii, p. 383, and also Calcutta Rev. 1xxix, p. 59.

${ }^{3}$ Raverty's Ṭabaqāti-Nāșirì, p. 670. 


\section{PROMOTION OF LEARNING}

pronunciation. $^{1}$ She was a patron of the learned. ${ }^{2}$ During Raziyah's reign, we hear of a college at Delhi called the Mu'izzi College. When the heretics Kirāmitah and Mulāhidah attacked Delhi in two bodies, one of them passing through the Bazar-i-Bazzāzān (the bazar of the clothmerchants) entered the gateway of the aforesaid college under the supposition that it was the Jami' Masjid and fell upon the people on both sides with their swords. ${ }^{3}$

The next two reigns of Bairām and Mas'ūd are educationally unimportant except for the patronage of Sirāj, the author of the Tabaqāti-Nāssiri, who was appointed the principal of Nāșirīyyā College and superintendent of its endowments. ${ }^{4}$

The next Sultān Naṣīruddīn occupies an important place in literary history. He was himself a scholar and during the long period of twenty years that he ruled found ample opportunities for advancing education. Even when a sovereign, he lived the life of a student and a hermit-a trait of character so rare in a king, and was in the habit of purchasing his food with the sale-proceeds of the products of his penmanship. ${ }^{5}$ A copy of the Qur'an

1 Ferishta vol. i, p. 217.

2 Vide Raverty's Tabaqāti-Nāșirī, p. 637.

3 Ibid., p. 646.

4 Tabāqati-Näșirī, Elliot ii, p. 344 ; Raverty, p. 667.

5 Ferishta vol. i, p. 246. 


\section{THE SLAVE DYNASTY}

transcribed by this sovereign with great taste and elegance was shown by Qāzị Kamāluddīn to Ibn Bațutah when he visited India about a century after. ${ }^{1}$ A scholar as he was, he respected and encouraged scholarship. $\mathrm{He}$ rose to be a great patron of Persian literature, and the celebrated Tabaqäti-Näsirì, which is so much drawn upon by historians for information regarding India and Persia, was written at his Court and took its name from the Sultān.

At this time, there seems to have existed a college at Jalandhar, in the hall of which the prayers for the 'Id-i-Āzhā were said by the followers of Ulugh Khāni A'zam on their journey back to Delhi after a successful expedition. ${ }^{2}$

Nașiruddin was followed by Balban who was also a great friend of literature, and his Court was a resort of many learned men. This was partly due to the then political condition of India and some of the neighbouring countries. It was at this time that Changīz Khān was ravaging Khurāsān and other places which made more than fifteen princes seek an honourable asylum at Delhi. Allowances befitting their position, and palaces were assigned to each of them, and it was upon this fact that Balban used to pride himself, whenever he had occasion to speak of this incident. In the retinue

1 Ibn Batūtah, Elliot iii, p. 593.

2 Raverty's T.. Tabaqāti-Nāssirì, pp. 678, 679. 
of these princes were some of the most illustrious men of learning of that time. The Court of the Indian Sultān was, therefore, at once a centre of learning and wealth. ${ }^{1}$

A remarkable feature of Delhi at this time was the abundance of its literary societies. Prince Muhammad, ${ }^{2}$ the eldest son of the Sultān, was a youth of very promising talents and evinced great taste for literature. He himself made a choice collection of poems extracted from the most celebrated authors. This work contained twenty thousand couplets which were esteemed the most select specimens then extant. This prince, with his marked literary tastes, took the lead in the formation of literary societies. Amir Khusrau the famous poet was the tutor of this prince and used to preside in the prince's literary society; the place chosen for the meeting of the members of this society was the prince's palace. ${ }^{3}$

There was another society inaugurated by the second son of the Sulțān named Kurrā Khān Baghrā. Musicians, dancers, actors and storytellers (qișșāhgus) were the members of this society and used to hold their sittings frequently at the prince's palace. ${ }^{4}$ The Amīrs followed suit. Within

1 Ferishta vol. i, pp. 251, 252, 258, 259.

2 An account of his education is given in the Nuh-Sipihr of Amir Khusrau (6th sphere), Elliot iii, p. 565.

3, 4 Ferishta vol. i, pp. 252, 258. 


\section{THE SLAVE DYNASTY}

a short time, various societies were formed in every quarter of Delhi. ${ }^{1}$ The Imperial House thus set a fashion in these refined amusements, which was fraught with possibilities of great good to the country at large.

The reputation of the royal Court in the literary world was kept at its high level, mainly through the patronage and literary tastes of prince Muhammad. The Court of this prince was frequented by the most learned and accomplished men of the time. His attendants used to read to him the Shäh-Nämah, the Diwani-Sanä'i, the Diwani-

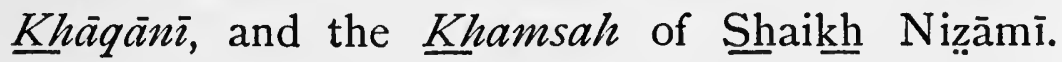
Learned men discussed the merits of those poets in his presence. $^{2}$

Besides Amir Khusrau the tutor, the prince had several other literary companions, among whom may be mentioned the name of Amir Hasan, also a great poet. The prince delighted to honour the two poets and marked his appreciation of their merits by grants of lands and proper allowances.

The literary ardour of this worthy scion of the Royal House expressed itself in the importunity with which he used to invite learned men to come to his Court and live there in the midst of all the

1 Ferishta vol. i, pp. 252, 258.

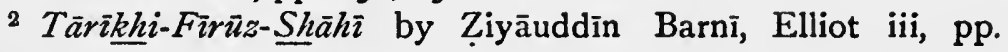
109, 1 Io. 


\section{PROMOTION OF LEARNING}

advantages of literary life that a generous prince could shower on them. At Lahore, he visited Shaikh 'Ușmān Turmūzì the most learned man of that age, but no presents or entreaties could prevail on him to remain out of his native country Türān. He twice sent messengers to Shīrāz to invite Shaikh Sa'di the famous Persian poet, and forwarded with them some presents and also money to defray the expenses of the journey. His intention was to build a Khänqāh (monastery) for him in Multan and endow it with villages for its maintenance. The poet through the feebleness of old age was unable to accept the invitations, but on both the occasions, sent some verses in his own hand and made his apologies in writing, commending also in high terms the abilities of Amir Khusrau the President of the prince's learned society. ${ }^{1}$

The prince was very fond of the company of the learned and could not forego it even in his military expeditions, in one of which he was killed and Khusrau taken prisoner.

The attitude of Sultān Balban towards the literary world was no less commendable. The advice which the Sulțān gave, on one occasion, to prince Muhammad shows that the monarch respected learned men and also realized the great

1 Tārīkhi-Fīrüz-Shāhī of Ziyāuddīn Barnī, Elliot iii, p. I10; Ferishta vol. i, p. 259 ; Tabaqāti-Akbar-Shāhī, MS. in the Bohār Collection of the Calcutta Imperial Library, p. 76 . 


\section{THE SLAVE DYNASTY}

help they could render to Government if only their wisdom were adequately utilized. He said-

"Spare no pains to discover men of genius, learning and courage. You must cherish them by kindness and munificence that they may prove the soul of your councils and instruments of your authority." 1

Again, his unique conduct in showing respects towards learned men on his return to Delhi from his successful expedition to Bengal reflects much credit on him. After conferring dignities upon Fakhruddin Kutwāl, who had ruled Delhi with much wisdom and ability during his absence for three years, he visited the learned men at their own houses and made them rich presents. ${ }^{2}$

In the long reign of Sultān Balban extending about twenty years, many an eminent and learned man flourished at Delhi. Besides the persons mentioned, there were Shaikh Shakarganj, Shaikh Bahāuddin and his son, Shaikh Badruddin 'Ārif of Ghazni the philosopher, the pious and learned Quṭbuddīn Bakhtiyār Kākī, Sayyid Maulā and many others eminent in various branches of science and literature. ${ }^{3}$

Delhi had been gradually rising in eminence through the attention of the Sultāns as a centre of learning and a resort of learned men. At the

\footnotetext{
1 Ferishta vol. i, p. 267.

2 Ibid., p. 265.

3 Ibid, p. 27 I.
} 


\section{PROMOTION OF LEARNING}

present moment, its literary position was so great that it inspired a few verses of Amir Khusrau, in which he declared with just pride that Delhi could now successfully compete with Bukhārā, the great university-city of Central Asia. ${ }^{1}$

About this time Sayyid Maulā, whom we have mentioned above, founded an academy and an almshouse at Delhi, of which we shall have occasion to speak later.

The next Sulțān, Kaiqubād, ruled only for two years, but during this short period he lowered the high tone of literary culture that had been introduced into the society of the day by Sultān Balban and his worthy son Prince Muhammad. He vitiated the literary taste of those who came within his influence by setting a bad example of loose life which they imitated. ${ }^{2} \quad$ As was the Sulțān, so were his subjects. The day of literary societies was gone, and wine and women reigned supreme. It does not take a long time to destroy what took decades to build.

The progress of education was set back during the reign of this profligate Sultān. In spite of his early education under strict tutors in the polite arts and manly exercises and in spite of his literary bent and wide reading, he succumbed to the

1 Vide Amir Khusrau's poem the 'Ashiqah.

2 Ferishta vol. i, p. 274, and Tärīkhi-Fìrüz-Shāhī, Elliot iii, p. 125. 


\section{THE SLAVE DYNASTY}

temptations of wealth when he ascended the throne.

In his time-

"his ministers as well as the young nobles of his Court, his companions and friends, all gave themselves up to pleasure; the example spread and all the ranks high and low, learned and unlearned, acquired a taste for wine-drinking and amusements." 1

1 Tärīkhi-Fīrūz-Shāhī, Elliot iii, p. 125, and Ferishta vol. i, p. 273. 


\section{CHAPTER IV. \\ The Khiljī Dynasty.}

THE establishment of a new dynasty inaugurated a new and better order of things. Sulțān Jalāluddin was of a marked literary taste. He used to pay learned men their due honour; and a literary atmosphere was created about the Royal Court which did not exist in the previous reign. His companions were distinguished as well for their sense and courage as for their wit and good humour, and renowned literary men of the time were frequently admitted to his private parties. Among these may be mentioned the following, famous for their erudition and for the works of poetry, history or science they composed :-

Amīr Khusrau, Tājuddīn 'Irāqī, Khwājah Hasan, Mu'yyid Dìwānah, Amīr Arslān Qulī, Ikhtiyāruddīn Yāghì and Bāqì Khațin.

The parties were enlivened not only by the feast

1 'Abdul Qādir mentions a few other names, e.g. Qāẓi Mughiș of Hansi, Mu'yyid Jājarmī, Sa'duddīn Mantaqī, etc.-MuntakhabulTawārīkh vol. i, p. 245 (Transl. by G. S. A. Ranking)-(Bibl. Indica).

See also Tārīkhi-Nizāmī, MS. in ASB, pp. 4I ff. 


\section{THE KHILJĪ DYNASTY}

of reason but also by the flow of music. The best singers, Amī Khașșah and Hamid Rajjah in unison with the best instrumental performers, such as $\mathrm{Mu}$ ḥammad Chungī, Futūḥā, Nașir Khāan and Bihrūz usually cheered up the august assembly. ${ }^{1}$

Amir Khusrau seldom allowed a party to take place without having prepared some new poem or song for the occasion, for which he was usually rewarded on the spot. ${ }^{2}$

A noticeable feature of Jalāluddīn's reign was that he chose the right person to fill the office of Librarian for the Imperial Library at Delhi. This high post, which carried with it much honour, was conferred on Amir Khusrau, who was held in high regard by Sulțān Jalāluddin. During the reign of Kaiqubād, Jalāluddin, while a prince, had settled on him a pension and rewarded him with I 200 tankas on his being appointed 'Ārizi-Mamālik. Sulțan Jalāluddin also appointed him the keeper of the Qur'an, raised him to the peerage and permitted him to wear white garments, a distinction usually confined to the blood royal and the nobles of the Court. $^{3}$

${ }^{1}$ Ferishta vol. i, pp. 292, 293 and Tärīkhi-Fìrüz-Shāhī, Elliot iii, pp. I $44 \mathrm{ff}$.

${ }_{2}^{2}$ Ferishta vol. i, pp. 292, 293 and Tärīkhi-Fìrüz-Shähī, Elliot iii, pp. I $44 \mathrm{ff}$.

${ }^{3}$ Ferishta vol. i, p. 293 and Tärīkhi-Fìrüz-Shähī, Elliot iii, p. I44. 


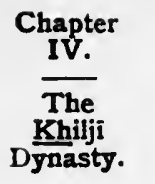

\section{PROMOTION OF LEARNING}

The record of Jalāluddin's work was soiled by the assassination of the great literary man of the age, Sayyid Maulā, who first established an academy at Delhi in the time of Balban. Sayyid Maulā was very pious and learned. His charity found expression in his alms-house for the entertainment of faqirs, travellers and poor men of all denominations. His charities were very large, and among his disciples and followers were many nobles and princes. The Sulțann's eldest son, Khān Khānān, used to visit him and call himself the Sayyid's son. The Sayyid was, however, suspected of plotting with his disciples against the Sultạn and was done away with.

Jalāluddīn's successor 'Alāuddīn was, however, a man of a different stamp. He was so uneducated that he could not read or write, and so arrogant and self-willed that men of learning tried to avoid his Court, or had to remain tongue-tied in his presence. ${ }^{1}$ As the emperor did not appreciate the value of education, he neglected that of his sons. He did not appoint any wise and experienced governors over his heir-apparent Khiẓr Khān and other sons, brought them out of the nursery long before their intelligence was mature, entrusting them at that stage with wealth and power which they abused. Buffoons and strumpets

${ }^{1}$ Ferishta vol. i, p. 333 ; also Tärîkhi-Fìrüz-Shāhì, Elliot iii, p. 168. 


\section{THE KHILJI DYNASTY}

obtained mastery over them, and their residences were often scenes of riotous parties given up to drunken merriments. ${ }^{1}$

In the case of 'Alāuddin, however, we find that he keenly felt within a short time the disadvantages of his illiteracy, applied himself privately to study and soon acquired a knowledge of Persian which enabled him to read all Addresses and acquaint himself with the best authors in the language. ${ }^{2}$ When he made such progress in his studies as to be able to follow learned discourses, he began to encourage discussions of literary subjects and "show favour to all the eminent men of that age," particularly to Qāẓi Maulānā Kuhrāmī and Qāzị Mughīṣuddinn. The latter of these two men was appointed to explain the law to the Sultān before whom he had often to quake when his explanations contradicted the Emperor's pre-conceived notions. ${ }^{3}$ The Sulțān was always of an

1 Tārīkhi-Fīrūz-Shāhì, Elliot iii, p. 207.

2 Ferishta vol. i, p. 348.

3 Ferishta vol.i, p. 348. The inscription on the southern doorway of the 'Alā'î Darwāzah of 'Alāuddīn Khiljī represents the Emperor to have been a great promoter of learning. The passages in the in: scription are:- " He ('Alāuddinn) of the exalted presence, Lord of the Kings of the world, Emperor like Moses in splendour, like Solomon in dignity, protector of the commands of the Law of Muhammad, helper of the observances of the religion of Ahmad, strengthener of the pulpits of learning and religion, strengthener of the rules of colleges and places of worship, etc., etc."-Carr Stephen's Archaeology of Delhi, p. 56. 
arbitrary temper, and the best informed men in his Court were careful to keep down their knowledge to the level of his acquirements. ${ }^{1}$ When the illuminating rays of learning penetrated his dark mind, we find him a little changed from what he had been before. He relented a bit towards literary men. On one occasion his hardened mind was softened by literary fervour, expressing itself in a reward of 1000 tankas and a gold-embroidered vest to Qāzị Mughīṣuddīn contrary to his expectations. ${ }^{2}$ But if he showed any favours to literary men, they were a select few, who were temporarily in the good graces of the whimsical Sultān; and we can take the above description of Ferishta, viz. that "he showed favours to all the eminent men of that age" in the sense that most of the men favoured had made themselves eminent by military prowess or administrative ability, and not by learning simply. As Barnī has said : "He ('Alāuddinn) was a man of no learning and never associated with men of learning." 3 Though this statement may be a little too strong, yet in the light of what another writer tells us on this point, it is perhaps not difficult to get at the truth. He says:

“During the time of Sultatan 'Alāuddinn, Delhi was the great rendezvous for all the most learned and erudite personages, for notwithstanding the pride and hauteur, the neglect and super-

1 Elphinstone (9th ed.) p. 390.

${ }^{2}$ Ferishta vol. i, p. 353.

3 Tārikhhi-Fìrūz-Shāhì, Elliot iii, p. 168. 


\section{THE KHILJĨ DYNASTY}

ciliousness, and the want of kindness and cordiality with which that monarch treated this class of people, the spirit of the age remained the same." 1

Indeed, this aggressive monarch did not confine himself to a merely passive superciliousness, but did positive harm to the cause of education and letters. A few months after the capture of Rintambor in I 299 A.D., the Sultān, we are told, directed his attention to the means of preventing rebellion, and with this view, he attacked the properties of his subjects.

" $\mathrm{He}$ ordered that wherever there was a village held by a proprietary right (milk), in free gift $\left(i^{\prime} \bar{a} m\right)$ or as a religious endowment (waqf), it should by one stroke of the pen be brought under the Exchequer. So rigorous was the confiscation that beyond a few thousand tankas, all the pensions, grants of land (in'am-wa-mafriuz), and endowments in the country were appropriated." 2

However, in spite of this high-handed tyranny of the monarch, we learn from Ferishta that-

" palaces, mosques, universities, baths, mausolea, forts and all kinds of public and private buildings seemed to rise as if by magic. Neither did there in any age, appear such $a$ concourse of learned men from all parts. Forty-five doctors, skilled in the sciences, were professors in the universities." 3

Before mentioning the names of the learned men who flocked to Delhi or flourished at the time, but who did not come under the royal patronage,

1 'Abdul Haqq Haqqī Dihlawī, Elliot vi, p. 485.

2 Tārīkhi-Fìrüz-Shāhì, Elliot iii, p. 179.

${ }^{3}$ Ferishta vol. i, p. 376 . N.K.T. has 46 doctors but no university. 


\section{PROMOTION OF LEARNING}

I shall name a few poets, most of whom, according to Ferishta, were recipients of pensions from the Court. These were Amir Khusrau, the prince of poets, our old acquaintance through several reigns, Amir Hasan, called the Sa'di of Hindustan, Șadruddin 'Alī, Fakhruddīn Khawāṣ, Hamīduddīn Rājah, Maulānā 'Ārif, 'Abdul Ḥakīm, Shahābuddīn Sadr Nashin, and several historians and compilers of memoirs of the times. ${ }^{1}$

Shamsul Mulk, the Prime Minister of Sultān 'Alāuddīn, was a very learned man, who counted among his pupils a great many of the scholars of the day. Had 'Alāuddin accepted all his advice, it would have been better for him and India alike. $^{2}$

Of the many poets and philosophers who flourished without the fostering care of the sovereign, the more famous only can be enumerated here. These were Sayyid Tājuddin, Sayyid Ruknuddin, the brothers Sayyid Mughișuddīn and Muntajïbuddin, all famous for their piety and learning. ${ }^{3} \quad$ The learned and pious Nizāmuddīn Auliyā, whose tomb in Delhi is looked upon as a very sacred place by all Muhammadans, also flourished at this time. The learned Shaikh

1 Ferishta vol. i, p. 377.

2 'Abdul Haqq Haqqī Dihlawī, Elliot vi, 484.

${ }^{3}$ Ferishta vol. i, p. 377. 


\section{THE KHILJĪ DYNASTY}

'Uṣmān, who is also known as Maqdūm Sirajuddinn, was his first pupil. Niẓāmuddin had a library. When, after his death, 'Ușmān removed to Lucknauti, he took away many important books from the saint's library. ${ }^{1}$

The study of theology and philosophy was zealously carried on under the care of the religious men some of whom have been already mentioned. Consequently, the following books on the subjects, viz. the Qutah-ul-Qaluib, the Ihya-ul-ulum and its translation, the 'Awärif and Kashf-ul-mahjüb, the Sharhi-T'arif, the Risälah-i-Qushivi, etc., were in great demand.

There was a number of nobles who upheld the cause of learning by their extensive liberality. There were the nobles of Nauhattah, who extended their patronage to a great many learned men, as also to students who came to study at Delhi. There were again the Sayyids of Gardiz, viz. Sayyid Jahjū and Sayyid Ajalī, who were also famous for their patronage of learning. The noble descendants of the Janjar family, viz. Mu'inuddin, Tājuddīn, Jalāl, Jamāl and 'Alī should also be mentioned for their acts of liberality. The Sayyids of Biānah were equally famous for their love of learning.

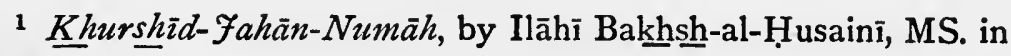
ASB. p. 214. 


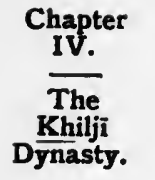

\section{PROMOTION OF LEARNING}

In Delhi at this time lived a large number of learned men, some of whom surpassed, according to Barnī, the most erudite of Bukhārā, Samarqand, Baghdād, Cairo, Damascus, Ispahān or Tabrīz. There were men learned in all the departments of knowledge, such as history (Badī' and Bayān), jurisprudence (Fiqh), logic (Ușũli-Fiqh), theology (Ușūli-dinn), grammar (Naḥw), commentaries on the Qurian (Tafsīr), etc. Barnì mentions also the following other names of learned men of Delhi :-

(I) Q. ${ }^{1}$ Fakhruddīn Nāqlāh.

(3) M. ${ }^{2}$ Nașîruddin Ghani.

(5) M. Zahiruddin Lang.

(7) M. Ruknuddīn Sunnāmī.

(9) M. Zahìruddin Bhakrī.

(I I) M. Kamāluddin Kolī.

(13) M. Minhājuddīn Qābnī.

(I5) M. Nașiruddīn Karah.

(17) M. 'Alāuddīn Tājr.

(I9) M. Hujuat Multānī Qadīm.

(2I) M. Burhānuddīn Bhakrī.

(23) M. Huusāmuddīn Surkhh.

(25) M. 'Alāuddin Kark.

(27) M. Hamíduddīn Baniānī.

(29) M. Fakhruddīn Ḥānsūĩ.

(3I) M. Șalăhauddin Satrkī.

(33) Ujiahuddīn Rāzì.

(35) M. Mirān Māriklah.

(37) M. Shamsuddīn Tum.

(39) M. 'Alăuddīn Lāhaurî.

(4I) Q. Shamsuddīn Gāžrūnī.

(43) M. Mu'inuddin Lunĩ.

(45) M. Mu'zuddin Andihnī.
(2) Q. Sharafuddīn Sarbāhī.

(4) M. Tãjuddin Maqdūm.

(6) Q. Mughișuddīn Biānah.

(8) M. Tãjuddīn Kalāhī.

(IO) Q. Muhyyiuddīn Kāshānī.

(12) Q. Ujiyāuddin Pailī.

(r4) M. Nizāmuddin Kalāhī.

(16) M. Naṣīruddīn Șābulī.

(18) M. Karìmuddin Jauharī.

(20) M. Hamīduddin Mukhlas.

(22) M. Iftikhāruddīn Barnī.

(24) M. Uhiduddīn Mulhū.

(26) M. Háasamuddīn ibn Shāāĩ.

(28) M. S Shahābuddīn Multānī.

(30) M. Fakhhruddin Shaqaāqil.

(32) Q. Zinuddīn Nāqlāh.

(34) M. 'Alāuddīn Șadr-ul-Shari'ah.

(36) M. Najibuddīn Sāwì.

(38) M. Șadruddin Gandhak.

(40) M. Shhamsuddin Bahī.

(42) M. Șadruddīn Tāwì.

(44) Q. Iftikhhāruddīn Rāzī.

(46) M. Najmuddin Intisḩār.

$$
\begin{aligned}
& { }^{2} Q=Q \bar{Z}=\bar{i} . \\
& { }^{2} \mathrm{M}=\text { Maulānā. }
\end{aligned}
$$




\section{THE KHILJI DYNASTY}

There were also M. 'Álimuddīn, Jamāluddīn Shāț̣ī, 'Alāuddīn Maqrī, Khwājah Zikī, the latter three being specialists in the Qur'an.

At this time in Delhi there were many famous men like Hindu Kathakas, such as M. 'Imāduddīn Hasan. They performed their Tazkirs once a week, and people flocked to hear them. M. Hamid and M. Latịif, and their sons, M. Ziyāuddin Sunnāmì and M. Shahābuddīn Khalīlī, were also noted for their ability in this sphere.

Amīr Arslān was a great historian, while Kabīruddīn was noted for his eloquence and proficiency in belles lettres in general. His Fath Nämahs are spoken of by Barnī as excellent works, with this defect that the darker aspects of 'Alāuddin were not touched at all in the book.

In the healing art, M. Badruddin Damashqi, M. Șadruddīn, Juwainī Țabīb, 'Âlimuddīn, etc., made themselves famous.

Barni mentions also a few noted astrologers, minstrels and musicians of the time.

Though there were so many famous learned men, 'Alāuddīn, as the historian says, did not appreciate their merit. ${ }^{1}$

It is indeed an irony of fate that the reign of an

1 For the above information (up to p. 37), vide Tärīkhi-FìrūzShāhī of Ziyāuddīn Barnī (Bibl. Indica), pp. 341-367; Niz̄āmuddīn Aḥmad also enumerates some learned men of 'Alāuddin's Court in his T. abaqāti-Akbarī, MS. in ASB, pp. 170 ff. (pp. 84 ff, N.K.T.). 
Emperor who did not like learned men and did many things, alike harmful and reprehensive, should form an important chapter in the literary history of Muhammadan India; but there are paradoxes in national as also in individual life.

An important fact should be noticed before we leave 'Alāuddīn's reign. Now that more than a century had elapsed since Muhammad Ghüri's arrival in India, there had already begun a racial intermixture, which was no doubt small, and a linguistic mingling and intercourse between the Hindus and the Muhammadans, brought about by the pressure of natural laws. The marriage of Dewal Devī, the daughter of the Rājā of Anhilpūr with prince Khiẓr Khān, the eldest son of Sulțān 'Alāuddinn, which inspired a poem of Amir Khusrau, shows that there had already been a breach in the social partition separating the Hindus from the Muhammadans; and it is superfluous to point out that linguistic intermingling had already commenced.

The reign of Mubārak Khiljī, the successor of Sulțān 'Aläuddīn, is another period of retrogression in literary history. We notice in many of his actions a repetition of the loathsome deeds of Kaiqubād. In Delhi, "Mubārak gave himself up to a course of the most degrading and odious debauchery." 1 From such a ruler it is futile to

1 Elphinstone (9th ed.) p. 392. 


\section{THE KHILJĪ DYNASTY}

expect any great attention to educational matters. There was, however, one bright feature in his reign. The Emperor restored the lands that had been confiscated by his predecessor, which no doubt meant the resuscitation of many a dead or moribund educational institution. 


\section{CHAPTER V. \\ The Tughlag Dynasty.}

THE short reign of Ghiyāṣuddin Tughlaq, the first Sulțān of the new dynasty, brought with it peace and order and served as a good prelude to an epoch remarkable for its educational improvements. Sulțān Ghiyāṣuddīn was fond of men of genius and learning, whom he used to invite to his Court. He constructed many public buildings and gave stipends to learned men, shaikhs and sayyids. $\mathrm{He}$ framed a code of laws founded upon the Qur'an and the ancient usages of the Delhi monarchy for guidance in the civil government of the country. ${ }^{1}$

The note struck in the short reign of this Sultān was taken up and prolonged through half a century, rising to its fullest pitch in the time of Fìrūz Shāh Tughlaq. But in the meantime the literary sphere was undergoing an eclipse. There was not now in

1 Tabaqāti-Nāșirī, Elliot ii, p. 318; and Ferishta vol. i, p. 402.

"A mile beyond the walls of the Tughlaqābād city is an isolated fortified little hill known as Nai's (or Barber's) Fort. This was apparently a college (Madrasah) or the retreat of some holy personage and was probably fortified as such against a possible Mughal attack."-Fanshawe's Delhi Past and Present, p. 291. 


\section{THE TUGHLAQ DYNASTY}

Delhi the same assemblage of learned men, whose presence in 'Alāuddīn's reign gave it its paradoxical nature. This made 'Abdul Haqq Haqqī speak in this lamentable vein-

"After the close of 'Alä's reign, the high standard of wisdom and erudition began to sink to an inferior level, and literature assumed quite another complexion; for although Sulțān Muhammad Tughlaq appreciated all sorts of learning, yet there was not such a number of learned men flourishing in his time as had congregated together under 'Alāuddīn's rule." ${ }^{1}$

This was due mainly to two causes. The first is the intervention of the barren and troublous reign of Mubārak Khiljī and the second the whimsical projects indulged in by Muhammad Tughlaq himself.

This Sulțān was, in the early part of his reign, a great friend of learned men. He was one of the most erudite sovereigns that ever sat upon the throne of Delhi. He was an accomplished writer and somewhat of a poet too. ${ }^{2} \mathrm{We}$ are told that in the ease of his composition, the play of his fancy and the sublimity of his style, he left the most accomplished teachers and professors far behind. $\mathrm{He}$ was an adept in the use of metaphors. He knew by heart a good deal of Persian poetry. In his epistles, which were in both Arabic and Persian,

1 Elliot vi, p. 486.

2 Barnīs Tärīkhi-Fīrüz-Shāhì, Elliot iii, pp. 235, 236; Ferishta vol. i, pp. 4Io, 41I ; and Voyages d'Ibn Batütah, by Defremery, tom. iii, p. 216. 


\section{Chapter}

The

Tughlaq

Dynasty :

Muhammad.

\section{PROMOTION OF LEARNING}

and were admired for their elegance, he showed himself skilled in metaphors, and frequently quoted Persian verses. He was fond of history and, his memory being very retentive, recollected almost every event he read of, along with its date. $\mathrm{He}$ was well acquainted with the Sikandar-Nämah, the Tärikhi-Mahmìì and the Bümi-Salim-Nämah. $\mathrm{He}$ was very eloquent and quite a master of debate. He could beat any literary man or scientist in his own weapon by his convincing arguments. In caligraphy, the Sultanan abashed the most accomplished scribes.

He was skilled also in the sciences of medicine, logic, astronomy and mathematics. He used to attend on patients afflicted with any extraordinary disease, in order to acquaint himself with its symptoms. He studied Greek philosophy, and after his accession to the throne held discussions with S'ad Mantaki the metaphysician, with 'Ubaid the poet, with Najmuddinn Intishār, Maulānā Zainuddīn Shīrāzī and several other learned men. Abul 'Abbās adds-

"The Sultann is noted for knowing the Holy Book by heart as also the law-book called Hidayah, which expounds the principles of the school of Abū Hanifah. . . . He is fond of reciting verses, composing them and hearing them read, when he readily seizes their most hidden allusions. He likes to converse with learned men and men of merit. He is also particularly fond of contending with poets in Persian-a language of which he is a master." 1

1 Masāilikul Absāar fí Mamālikil Amșār of Shahābuddin Abul 'Abbās Ahmad, Elliot iii, p. 580 . 


\section{THE TUGHLAQ DYNASTY}

$\mathrm{He}$, however, took no delight in works of fiction such as tales and romances. ${ }^{1}$

We do not hear much as to who had the charge of educating the Sultān in his infancy and youth, except that Qutlugh Khān was one of his preceptors, whom he appointed Governor of Daulatābād.²

Famous as he was for his intellectual accomplishments, he was not less so for his gallantry in the field and beneficence to the poor. He established hospitals for the sick and almshouses for widows and orphans on a very liberal scale. Besides, in the early part of his reign, he was very liberal to scholars, and his liberality attracted to Delhi some of the most learned men of Asia, who returned to their countries laden with honours and presents.

But he had two black traits in his character. $\mathrm{He}$ was of an irascible temper and visited with excessive cruelty those with whom he became angry. Under the influence of his rage, he even put to death quite a number of men, though they were learned and holy, for offences which never merited the extreme punishment. ${ }^{3}$ The other unwelcome trait was his whimsical temper, which had so chilling an effect on the literary cause. One

1-2 Defremery's Voyages d'Ibn Batūtah, tom. iii, p. 45 ; also Ferishta vol. i, p. 48o, and Ferishta vol. ii, p. 285. Another name of the preceptor was 'Álim-ul-Mulk.

3 Defremery's Voyages d'Ibn Bațuttah, tom. iii, pp. 290 ff. 
of the most absurd projects which entered his head was to make Deogir his capital as soon as possible, under the changed name of Daulatābād. To give effect to this whim, he at once ordered the people of Delhi to leave it on pain of death and to remove to Daulatābād. Some time after, however, they were allowed to return to the old capital, but were again compelled to leave it. These caprices of the Emperor not only caused the utmost misery to the people, but at the same time brought ruin upon Delhi as a great literary centre. The graphic description of Ziyā Barnī the historian, who lived at the Court of Sultān Fìrūz, depicting the utter ruin that fell upon the quondam capital, brings home to our mind the great loss that the country sustained at the time from the literary standpoint:-

"The second project of Muhammad Tughlaq was to make Deogir his capital. This brought ruin upon Delhi-that city which for 170 or 180 years had grown in prosperity and rivalled Baghdād and Cairo-with its sarais, its suburbs and villages spread out 4 or 5 kos. All was destroyed. So complete was the ruin that not a cat or a dog was left in its buildings, in its palaces or its suburbs. The Sultān brought learned men and gentlemen, tradesmen and landholders into the city and made them reside there. But this importation of strangers did not populate it ; many of them died there, and many more returned to their native houses." 1

Ibn Bațutah, the most energetic globe-trotter of Tangier, who visited India in $134 \mathrm{I}$ and was cordially received by the Emperor, also testifies to

1 Tārīkhi-Fìrūz-Shāhi, Elliot iii, p. 238. 


\section{THE TUGHLAQ DYNASTY}

the fact: Delhi, he says, one of the greatest and most magnificent cities in the world, was at the time like a desert and had the fewest inhabitants.

It was thus that the greatest centre of Muhammadan learning in India was deserted by the literate; its schools and colleges, so long the resort of thousands of students, were left with few or none of their alumni. Could the upstart capital of Daulatābād, raised to its high position by the irresistible caprice of a whimsical Sultān, create for it the literary reputation, tradition and atmosphere which were the invaluable assets of the deserted capital ?

However, as the Sulțann was of a literary disposition, he was never without a circle of learned men about him; but though the literary men whom he took with him to Daulatābād or who went there of their own accord could never make up for what had been lost, yet it must be admitted that the Royal Court throughout the reign of Sulțān Muhammad was marked by a high literary tone. What provisions he made for the education of his subjects in his new city we are not in a position to say; but it is not at all likely that the literary Sultān would build his capital without any suitable madrasah as its educational ornament, as Fīrūz Shāh his successor would do in his own Fìrūzābād. However, the early part of his reign will always be remembered for the large influx of 
learned men who were attracted to Delhi by the Emperor's liberality and literary taste. It was this fact that made Abūl 'Abbās Aḥmad burst forth into a high-flown statement which cannot perhaps be taken without a pinch of salt. He says that at the Royal Court at Delhi there were a thousand poets skilled in one of the three languages, Arabic, Persian or Indian, and twelve hundred physicians; and that at his private meals the Sultān received learned lawyers to the number of two hundred, who sat with him at the table and conversed on learned subjects. $\mathrm{He}$ also refers to an arrangement under which men of letters, whether native or foreign, were under the inspection of the Sadri-Jahān and some secretaries. ${ }^{\text {}}$ $\mathrm{Be}$ that as it may, the Sultān should be given his due share of praise for his encouragement of literary men in the first few years of his administration with a profusion reputed to have been without a parallel. Of the learned men who visited his Court at the time may be mentioned Nașiruddīn, 'Abdul 'Azīz, Shamsuddīn, 'Aẓududdīn, Majduddīn and Burhānuddin. ${ }^{2}$

One noteworthy fact is that the historian Barni, the author of the Tárikhi-Firiuz-Shähi, was called by the Sultān twice to give him advice on administration, but his advice fell on deaf ears. ${ }^{3}$

1 Masālikul Abṣār fī Mamālikil Amṣār of Shahābuddīn Abul 'Abbās Ahmmad, Elliot iii, pp. 575 and 579.

2 Defremery's Ibn Bațutah, tom. iii, pp. $250 \mathrm{ff}$.

3 Elliot iii, pp. 254, 255. 


\section{THE TUGHLAQ DYNASTY}

Had this Sultān been a little more steady in mind, he could have bestowed on Muhammadan India a full share of the educational benefits and literary encouragement that were expected from the personality of the monarch. But it was fated otherwise.

With the death of the monarch, Daulatābād lost its patron, and Delhi began to recoup itself. But it could not get back its former position, for Fìrūz Tughlaq came to the throne with the scheme of building a new capital; and no sooner did he wear the crown than we find him starting his building operations for the purpose. This capital, however, did not become like that of his predecessor a source of misery and oppression to the people of Delhi for the reasons that it was very near the latter and that the monarch did not cause any compulsory exodus. The contiguity of the old and the new capitals made them to some extent partners of the same lot; so that when Fìrūzābād rose in prosperity and fame as an educational centre, Delhi did not fail to rise pari passu. But the younger sister threw for a time the elder into the shade.

If peace hath her victories no less than war, Fìrūz Tughlaq stands in the forefront of Muhammadan rulers of India, anticipating in many ways the crowning work of Akbar.

Sulțān Fìrūz was as just and good an administrator as he was bountiful and liberal, and sought 


\section{PROMOTION OF LEARNING}

during his reign to contribute as much to the material prosperity of his subjects as to their education and culture.

In his youth he was trained in the art of government by his uncle Ghiyāșuddin Tughlaq, who in his long tour through his dominions took Fìrūz with him to acquaint him with political problems at first hand. When Muhammad Tughlaq came to the throne, Fìrūz was treated with the same care and attention; Muhammad made him Deputy of the Lord Chamberlain, with the title of Nä'ib Bārbak, and gave him the command of 12,000 horse. The Sulțān used to keep him constantly near his person, and explain to him all affairs of State that came up for consideration; and when the territory was divided into four parts by the Sultān, he was placed in charge of one, in order that he might acquire experience in the art of government. Thus Fìrūz was kept continually in touch with various matters concerning State which made him well versed in the duties of royalty and taught him to bring to bear on administration the good sense with which he was endowed. ${ }^{1}$

His literary education was equally satisfactory. He was himself the author of an elegant autobiography Futīhāti-Fìnüz-Sh $\bar{a} h \bar{i}{ }^{2}{ }^{2} \mathrm{He}$ was very

${ }^{1}$ Shamsi Sirāj 'Afif's Tārīkhhi-Fīrūz-Shāhī, Elliot iii, pp. 274, 275.

${ }^{2}$ Ferishta vol. i, p. 46 I. 


\section{THE TUGHLAQ DYNASTY}

fond of history, and among the historians who lived at his court were the famous Ziyãuddin Barnī and Sirāj 'Afíf. After Barnī's death, the Sulțān, it is said, expressed to every learned man he met, his great desire for an historical record of the events of his reign. But with the high standard by which he judged an historian, he did not find any one to his liking; and in despair he caused a few lines of his own composition bearing on his reign to be inscribed in letters of gold on the walls, domes and minarets of his two palaces Küshki-Shikār and Kūshki-Nuzūl at Fĩrūzābād. ${ }^{1}$

His high regard for learned men is manifested in the arrangement he made for their reception at the Court. He built three palaces, which he named (I) the Palace of Grapes, (2) the Palace of the Wooden Gallery, and (3) the Palace of the Public Court; the first of which was for the reception of the distinguished learned men as also of the noblemen of the country. The second was for the reception of his principal personal attendants, and the third for general receptions. ${ }^{2}$

The large sum of money he spent in encouraging the learned shows his zeal for education. He spent 136 lacs of tankas in pensions and gifts, of which 36 lacs were given to the learned and religious. ${ }^{3}$

1-2 'Afīf's Tārīkhi-Fīrüz-Shāhī, Elliot iii, pp. 316, 343.

3 Ibid., Elliot iii, p. 317. 


\section{PROMOTION OF LEARNING}

Fîrüz.

Fīrūz Shāh was perhaps the first Sulțān who took care to preserve those archaeological remains in the country that struck him as curious and worthy of his attention. The careful and expensive way in which the two Asoka columns, one in the village of Topra in the district Khizrãbãd in the hills, and the other in the vicinity of the town of Meerut, were brought to his capital, shows a taste for archaeology in the Sultān and a respect for Hindu monuments which were rare in those days. It was supposed that these columns had stood there from the time of the Panduavas, and the historian 'Afif was inclined to take them as the walkingsticks of the giant-like Bhima of the Mahäbhärata. One of the columns was erected in the palace at Fīrūzābād near the Jami' Masjid and called the Golden Column, ${ }^{1}$ while the other was placed in the Hunting Palace, ${ }^{2}$ with great labour and skill. ${ }^{3}$

The process of removal of the massive monuments in those days before the era of mechanical or electric locomotion is full of interest to us. Khizrābād, the place where one of the pillars stood, is

1 Minār-i-Zarrīn.

${ }^{2}$ Kūshhki-Shikār.

3 "The two Asoka pillars, which now stand near Delhi on the Kotila and the Ridge respectively were transported by Sultān Fìrūz Shāh, the one from Topra in the Umballa district now in the Punjab and the other from Meerut in the United Provinces." V. Smith's $A$ soka, 2nd ed., p. I 2 I. 


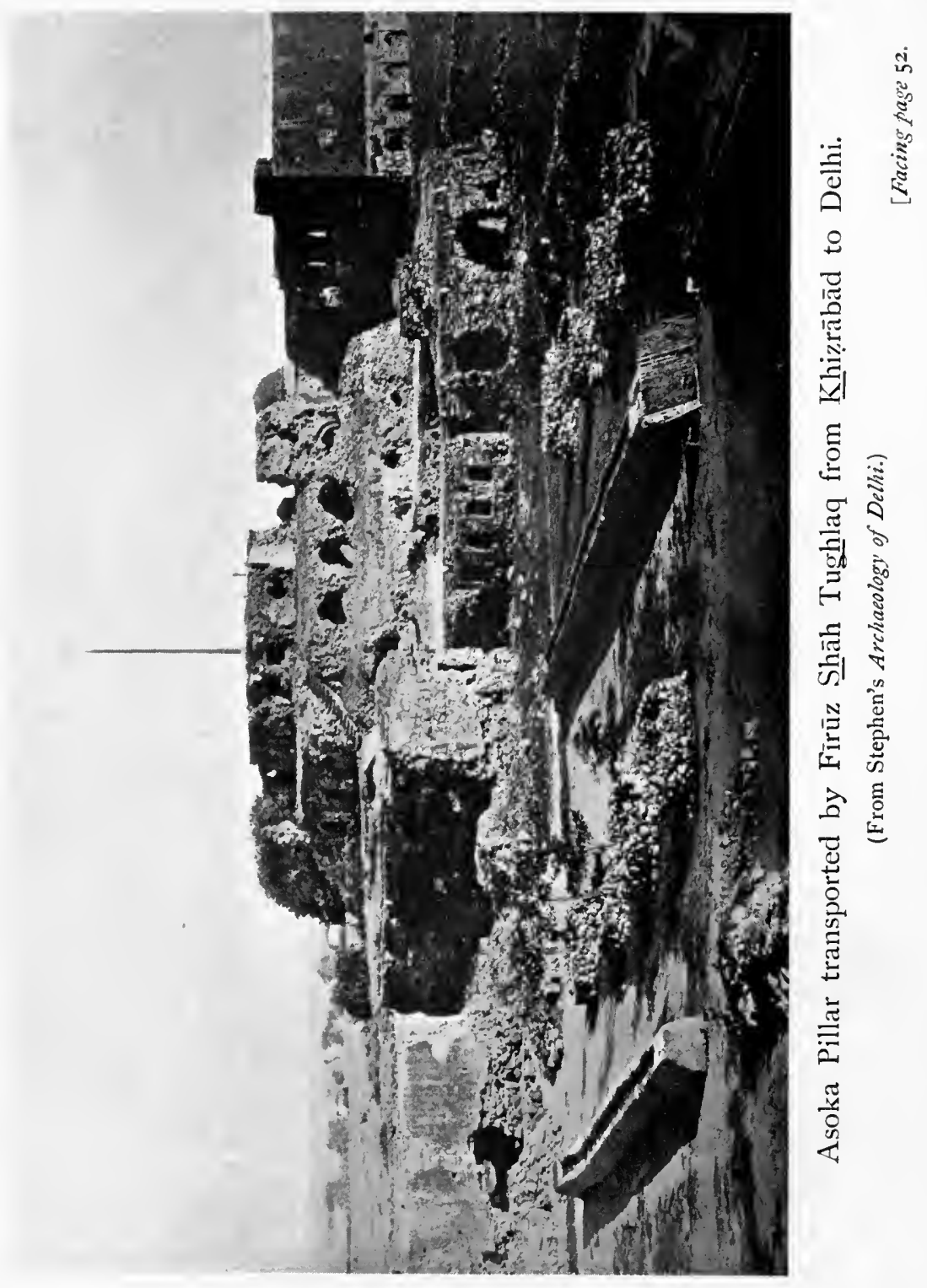




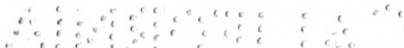




\section{THE TUGHLAQ DYNASTY}

about 90 kos from Fīrūzābād. When the Sulțān saw it, he resolved to remove and erect it as a memorial that should perpetuate his own memory and excite the admiration of future generations. Orders were issued to the people in the neighbourhood and also to the soldiers to bring implements and materials suitable for the work. Quantities of silk-cotton were placed round it ; so that, when the surrounding earth was removed, it fell gently on the bed prepared for it. It was encased in reeds and raw skins from top to bottom. A carriage with 42 wheels was constructed and ropes were attached to each wheel. The pillar was raised on the carriage, which was then hauled up to the banks of the Yamuna by thousands of people. A number of large boats, some of which could carry 7000 mans of grain, and the smallest of them 2000 mans, had been kept there to receive the column, which was now ingeniously transferred to its new vehicles and conducted to Fìrūzābād. It was set up with great skill in a building made for its reception, and many Brāhmañas and Hindu devotees were invited to decipher the characters on the monument, but were not successful. ${ }^{1}$

The other pillar was also removed by the Sultān

${ }^{1}$ Shamsi Sirāj 'Afif, Elliot iii, p. 350; V. Smith's Asoka (2nd ed.), pp. 121-I23, I25; also Cunningham's Archaeological Survey Report, vol. xiv, p. 78 ; and Carr Stephen's Archaeology of Delhi, p. I3I. 
with similar dexterity and erected in the Hunting Palace amid great feasting and rejoicing. ${ }^{1}$

Sulțān Fīrūz's taste for the fine arts was influenced by his religious ardour. It was usual with many previous Muslim monarchs to have painted chambers to gratify their eyes in retirement. But Fìrūz Shāh ordered that there should be no portraits anywhere in his palace, as it was contrary to Muslim Holy Law. But he allowed garden scenery to be painted. ${ }^{2}$

Every Friday after public service, parties of musicians from every quarter of Delhi, story-tellers and athletes amounting in all to about 3000 , used to attend at the palace to divert the Sulțān. ${ }^{3}$

A peculiar fancy of the Sultān was to have slaves, whom he educated and for whom he made good provision. When the Sultān prohibited the practice hitherto prevalent of taking presents from the chiefs, the latter, noticing his eagerness for slaves, began to present him with nothing but slaves in large numbers. The Sultān used to send them to the feudal dependencies when they were too many in number. But provision was always made for their support in a liberal manner.

Some of the slaves were to spend their time in reading and committing to memory the Holy Book, 


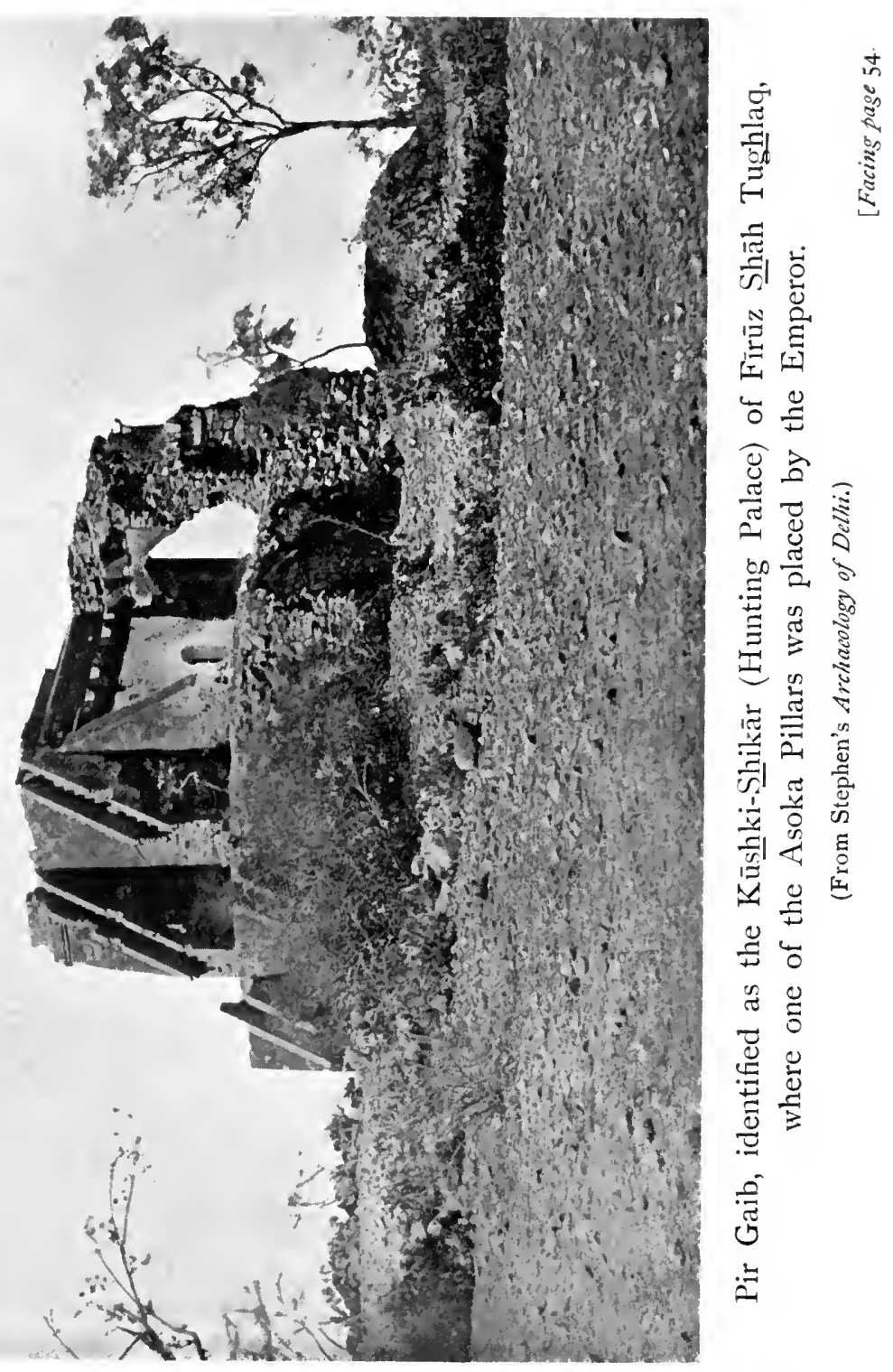




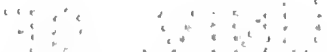

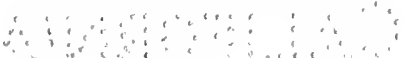




\section{THE TUGHLAQ DYNASTY}

others in religious studies or in copying books. Some were placed under tradesmen to be taught mechanical arts, so that about 12,000 slaves became artisans of various kinds working for the Sulțān. Altogether, in the city and in the various fiefs, there were 18,000 slaves for whose maintenance and comfort the Sultān used to take special care. To such an extent was this matter carried, that there were separate officers for looking after the slaves and a separate treasury for the payment of their allowances, directly under the Sultan himself and not under the Prime Minister. ${ }^{1}$

This was similar to Muhammad Ghūrīs hobby of educating slaves, as mentioned before.

The Sultāan's taste for art, a glimpse of which we have obtained in the careful preservation of the Asoka pillars, manifested itself also in the manner in which he utilized the products that the applied science of those days could turn out. It is needless to point out that the use of these things by the Emperor served as a stimulus to the craftsmen concerned.

Of the many wonderful things that were contrived at the instance of Sultạn Fìrūz, was the Țāsi-gharyāl (seven different uses of the Ṭās in marking time and making known the hours of prayer). ${ }^{2}$ It was placed on the top of the Darbār

1 'Afíf, Elliot iii, pp. 340, 34 I.

2 Clepsydra, or water-clock. 


\section{Chapter \\ The \\ Tughlaq \\ Firūz.}

\section{PROMOTION OF LEARNING}

Hall of the palace at Fìrūzābād, and people crowded to see it. ${ }^{1}$

In the long list of the preceding Muhammadan Emperors, there was none who tried so much for the diffusion of education among his subjects as Sulțān Fìrūz. He was the initiator of many important and excellent regulations in his reign, the most noteworthy of which was the one that related to the encouragement of learning. This regulation ${ }^{2}$ declared with the emphasis that a royal edict carries with it, that it was an important part of his State policy to encourage learned men whom he caused to reside in the different parts of his empire for imparting instructions to the people.

Another portion of the edict runs thus:-

"I have considered it my duty to repair every public edifice of utility constructed by my predecessors, such as caravansarais, masjids, wells, reservoirs of water, aqueducts, canals, hospitals, almshouses and schools, and have alienated considerable portions of the revenue for their support." 3

In the list of the works of public utility furnished by Ferishta, the educational institutions started by the Sulțān play not a small part :-

" 50 Dams across rivers to promote irrigation,

40 Mosques,

30 Colleges, with mosques attached,

1 'Afif, Elliot iii, p. 338.

2 Vide Nizāmuddīn A ḥmad, as quoted in Ferishta vol. i, p. 462.

3 Ferishtä vol. i, p. 464. 


\section{THE TUGHLAQ DYNASTY}

20 Palaces,

100 Caravansarais,

200 Towns,

30 Reservoirs or lakes for irrigating lands,

100 Hospitals,

5 Mausolea,

IOO Public Baths,

Io Monumental Pillars,

Io Public Wells,

I 50 Bridges;

besides numerous gardens and pleasure-houses. Lands were alienated at the same time for the maintenance of these public buildings in order to keep them in thorough repair." 1

It is interesting to hear from the Sultān himself some particulars about these building operations :-

"Among the gifts which God bestowed upon me, His humble servant, was a desire to erect public buildings. So I built many mosques, colleges and monasteries, that the learned and the elders, the devout and the holy, might worship God in these edifices, and aid the kind builder with their prayers. The digging of canals, the planting of trees and the endowing with lands are in accordance with the directions of the Law.

"Again, by the guidance of God, I was led to repair and

1 Ferishta vol. i, p. 465. It is not supported by N.K.T. See also Tabqāti-Akbarī by Nizzāmuddīn Aḥmad, MS. in ASB, p. 243.

Accounts vary as to the exact number of colleges built by Fìrūz. The $M a^{\prime}$ assiriri-Rahìmī by 'Abdul Bāqĩ (MS. in ASB, leaf 107) states that he built 50 Madrasahs; the Khulassatul-Tawārikh (MS. in ASB, leaf I $_{5}$ ) by Sūjan Rāi Khattrī gives the number as 30. According to $\mathcal{F} \bar{a} m i$ 'ul-Tawārikh by Faqī Muhammad (p. 310), the number is 40 , while the Tabaqäti-Akbari and Ferishta state it as 30. E. Thomas, the author of the Chronicles of the Pathan Kings of Delhi (p. 29I), mistrusts the totals given by the last two works. In the midst of this confusion, it is very difficult to find out the truth. 


\section{Chapter \\ The}

Tughlaq

Dynasty :

Fîrūz.

\section{PROMOTION OF LEARNING}

rebuild the edifices and structures of former kings and ancient nobles which had fallen into decay from lapse of time, giving the restoration of these buildings the priority over my own building works. The Jami' Masjid of old Delhi, which was built by Sultān Mu'izzuddin Sām, had fallen into decay from old age and needed repair and restoration. I so repaired it that it was quite renovated.

"The Madrasah (College) of Sultān Shamsuddin Altamash had been destroyed. I rebuilt it and furnished it with sandal-wood doors. The columns of the tomb, which had fallen down, I restored better than they had been before. ${ }^{1}$ When the tomb was built, its court had not been made curved; but I now made it so. I enlarged the hewn stone staircase of the dome and re-erected the fallen piers of the four towers. . . .

"I repaired the tomb of Sulțān 'Alāuddinn and furnished it with sandal-wood doors. I repaired the wall of the ābdār-khāna ${ }^{2}$ and the west wall of the mosque which is within the College, and I also made good the tesselated pavement. . . .

"I also repaired the doors of the dome and the lattice-work of the tomb of Shaikh-ul-Islām Nizām-ul-Haqq Wauddin, which were made of sandal-wood. I hung up the golden chandeliers with chains of gold in the four recesses of the dome, and I built a meeting-room, ${ }^{3}$ for before this there was none.

"The expense of repairing and renewing these tombs and colleges was provided from their ancient endowments. In those cases where no income had been settled on these foundations in former times for procuring carpets, lights and furniture for the use of travellers and pilgrims in the least of these places, I had villages

1 For identification of this Madrasah, see Arch. Survey Report, vol. $\mathrm{xx}, \mathrm{pp}$. I $45, \mathrm{I} 46$.

"Both the college and the ābdār-knhāna which, Fīrūz Shāan says, he repaired, were in the rooms in the eastern and western walls of the tomb."-Carr Stephen's Archaeology of Delhi, p. 89.

2 'Afíf, Elliot iii, p. 354 .

3 The meeting-rooms attached to tombs are not an uncommon feature of the sepulchral monuments. The tomb of Shaikh Salāhuddin, a man of piety and learning of the time of Muhammad Tughlaq, built in I353 A.D., near the village Khirki, possessed such M ajlis Khānas. (C. Stephen's Archaeology of Delhi, p. I2 I). 


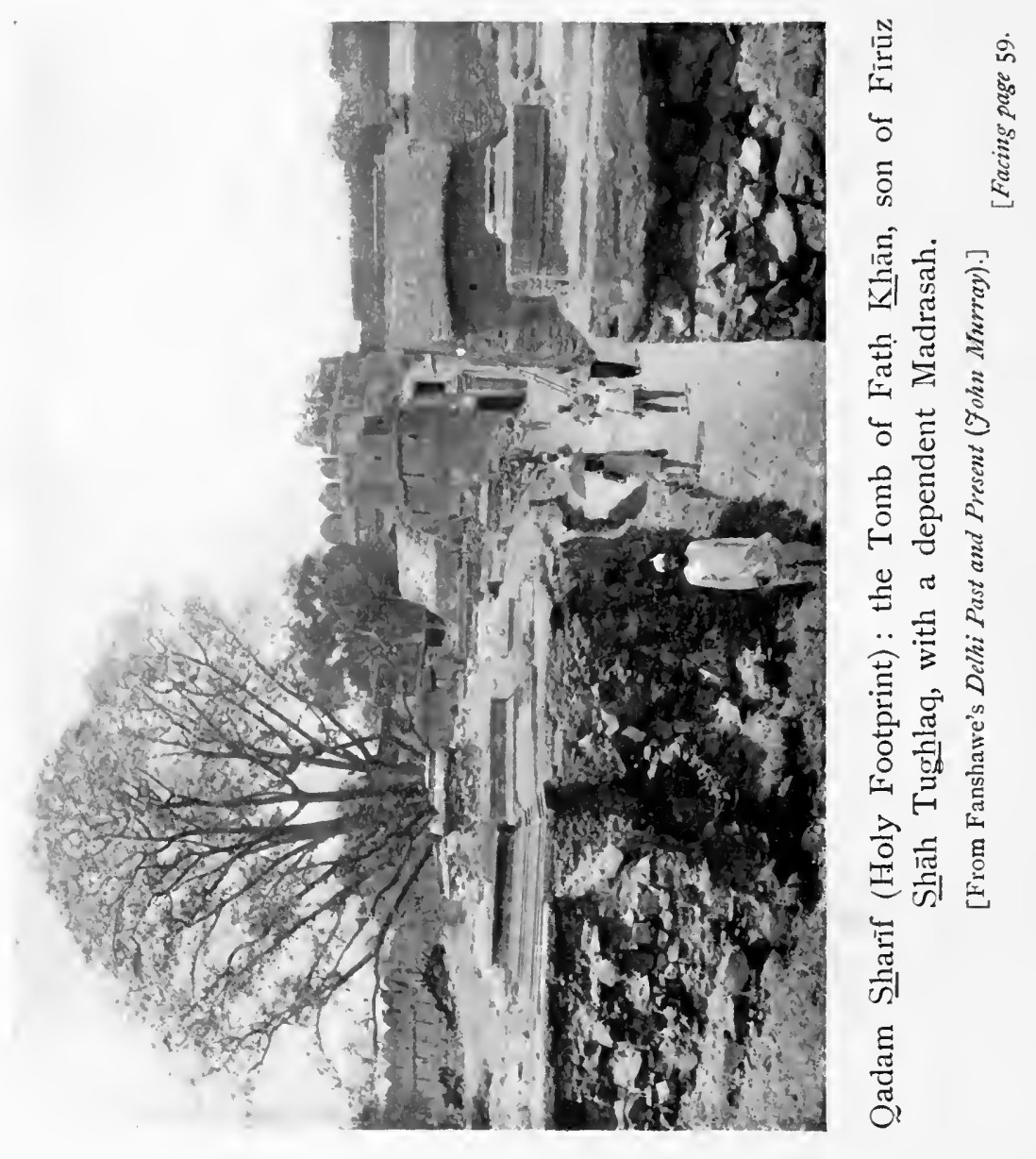




\section{THE TUGHLAQ DYNASTY}

assigned to them, the revenues of which would suffice for their expenditure in perpetuity." 1

These details heightened in their interest, coming as they do from the pen of the royal benefactor himself, acquaint us with two interesting facts, one regarding the college of Sultãn Altamash and the other about that of Sulțān 'Alāuddīn. We do not know who built the latter college, but as it is attached to 'Alāuddin's tomb, it was very likely constructed by his son as a memorial to the deceased Sulțān.

Of the colleges with masjids built by Fìrūz Shāh, one was near the tomb of Fath Khän, known as the Qadam Sharif, ${ }^{2}$ with an adjacent masjid and a reservoir to perpetuate the memory of Fath, the son and heir-apparent of the Sultăn, who died in $1374 .^{3}$

1 Futūhàti-Fìrūz-Shāhi, Elliot iii, pp. 382-384.

2 The inscription over the doorway of the inner enclosure of the Qadam Sharif is as follows:-

"The guide of those who have lost (their way), Muhammad!

"The preacher of preachers, Muhammad!

"Glorious is the Madrasah, the pulpit and the house. In the midst of which is read the praise of Muhammad!

"For broken hearts $\mathrm{He}$ is a (healing) balm!

"For the afflicted in the heart, Muhammad is a comfort! etc., etc."-Carr Stephen's Archaeology of Delhi, p. 147.

The Qadam Sharif is about a mile and a half to the south of the Lahore Gate of modern Delhi.

3 Vide Thomas's Chronicles of the Pathān Kings of Delhi, p. 298 ; Fournal Asiatique, 1860, p. 4 II ; Sayyid Ahmad, p. 37, and its translation by Garcin de Tassy, p. II 2. 


\section{PROMOTION OF LEARNING}

Another college was at Fīrūzābād and known as Fīrūz-Shāhì-Madrasah. Its brilliant description by Barni gives us to understand that both in literary reputation and in the beauty of its architecture and finish, it far surpassed all the other Indian madrasahs of the time. Indeed, it is no wonder that Fīrūz Shāh in his love for his new capital and his zeal for the cause of learning should gather up and use all the vast resources he could command as an Emperor to found a college in which nothing would be left to be desired either in external splendour or in the internal arrangements for its inmates.

The madrasah was a very commodious building embellished with lofty domes and situated in an extensive garden adorned with alleys and avenues and all that human art combined with nature could contribute to make the place fit for meditation. ${ }^{1}$ An adjacent tank mirrored in its shiny

${ }^{1}$ Carr Stephen describes a college built by Fìrūz Shāh on the side of the tank called Hauz 'Alā'í or Hauz Khāṣ. Says he : "This magnificent tank, covering over 70 acres of land, was built by Sulțān 'Alāuddīn Khiljī in the year 695 A.H. (I295 A.D.), and was enclosed by a stone and masonry wall. In the reign of Fìrūz Tughlaq (about 755 A.H., I 345 A.D.), it was filled up, and there was no water in it. People carried on cultivation in it and had dug wells, of which they sold the water. Fìrūz cleared it out. . . . The repairs then done to the tank were so extensive that Timür ascribes the tank itself to Fīrūz Shāh. 'This is a reservoir,' writes Tìmūr, 'which was constructed by Sultān Fīrūz Shāh, and is faced all round with cement. Each side of that reservoir is more than a bow-shot long, and there are buildings round it. This tank is filled up by the 


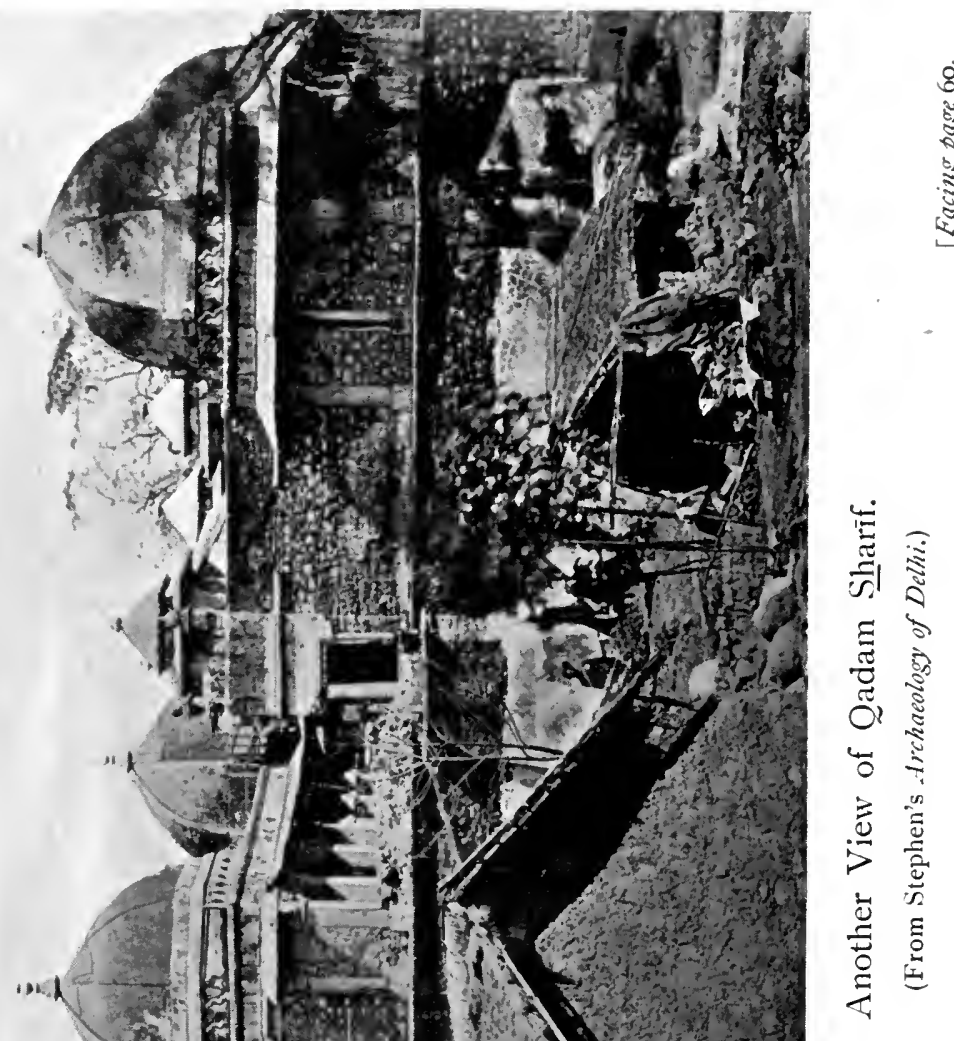


$\therefore$ $\because \vdots \vdots \vdots$ 


\section{THE TUGHLAQ DYNASTY}

and placid breast the high and massive house of study standing on its brink. What a charming sight was it when the madrasah hummed with hundreds of busy students walking its clean and smooth floors, diverting themselves on the side of the tank, or listening in attentive masses to the

rains in the rainy season, and it supplies the people of the city with water throughout the year.' "-Vide C. Stephen's Arch. of Delhi, p. 83; vide also Malfüzãti-Tìmürī, Elliot iii, p. 44I. Stephen says that Yazdī, who copies and not seldom distorts Malfüzāti-Tìmūri calls the Hauz "a deep and wide well, one of the works of Fìrūz Shāh." Here Stephen obviously misinterprets Yazdī, who uses the word درياح (dariāchah), which means a small river to which he compares the Ḥauz Khāạ. Now, "chāh," when separately used, means a well. Stephen confuses this meaning of the word with its signification as a diminutive particle (cf. dar, door, and darichah, small door). See Yazdī's Zafar-Nāmah, MS. in the Bohär Collection, leaves 246,247 .

Stephen further says: "In the year 753 A.H. (I352 A.D.) Fìrūz Shāh built a college (Madrasah) at the top of this tank (TārîkhiMubärak-Shāhin). Almost the entire length of the southern side of the Hauz consists of old buildings. The Madrasah of Fīrūz Shāh is a range of low masonry rooms and now partly in the occupation of villagers, who use them for the ordinary purposes of residence. The Mutwallī of the Madrasah, Sayyid Yūsuf bin Jamāl died in 790 A.H. (I388 A.D.) and was buried in the courtyard of the college."Carr Stephen's Archaeology of Delhi, p. 83 (1876).

It is difficult to say whether this college is the same as the Fìrūz-Shāhī-Madrasah described above. The tank mentioned by Stephen is not in a garden, and the buildings on its side are of a small height and have no lofty domes. The only common feature that strikes us is the adjacency of the tank to the college. This is, however, too flimsy a ground upon which to base any conclusion as to the identity of the two colleges. "The Hauz Khāṣ still exists with several buildings on its eastern side. Amongst them is the tomb of Fīūz Shāh with a masjid and a madrasah close by."Arch. Survey Report, vol. xx, p. I5 I (1882-1883). 


\section{PROMOTION OF LEARNING}

learned lectures of the professors from their respective seats ! ${ }^{1}$

Of the learned men to whom the responsible task of educating the young alumni of the college was entrusted, we hear only of two. There was Maulānā Jalāluddīn Rūmī, ${ }^{2}$ the renowned master of many subjects, who used to lecture on theology, explain to the students the Fiqh (jurisprudence) and the commentaries on the Qurann, and teach them the time-honoured traditions. The other professor was a great religious teacher, and had hailed from Samarqand.

Both the students and the professors had to reside within the college, and so there were the facilities that a constant communion among the students themselves as well as between the tutors and the taught could afford. The college was not, as can already be anticipated, a place for exclusively secular studies only, but in it was also carefully looked after the spiritual well-being of the students. There was a big masjid attached thereto, in which the five compulsory as well as the extra prayers were regularly said, the former being performed in gatherings conducted by the Șüfis, who at other times remained engaged in counting beads and praying for the well-being of the Sultān. The

1 The description of the beauty of the college building and reference to seats, smooth floor, etc., are found in Ziyāuddin Barnī.

2 Not the renowned poet of that name. 


\section{THE TUGHLAQ DYNASTY}

Hāfizes (those who learnt by heart the Qur'ān) had to recite the whole $Q u r^{\prime} \bar{a} n$ and pray for the Emperor and all the Musalmāns.

There were separate apartments in the college for the reception and accommodation of the travellers who, attracted by its reputation, paid it visits from distant countries.

The college was also noted for bounty and charity to the poor and the needy, for in its masjid they received the help they wanted.

There was a suitable provision for the bestowal of stipends and scholarships upon the successful students, and over and above these, every inmate of the madrasah, be he a student, professor or traveller lodging there, received a fixed daily allowance for his maintenance. All these expenses were defrayed out of the State endowments as well as, in this particular case, out of the sums of money that were set apart by the State for being given in charity, to contribute to the well-being of the Emperor.

Where is now this madrasah, the glory of its age, with which the colleges of Delhi, though famous, could never, according to Barnī, stand in rivalry? It is now buried, along with its beauty and grandeur, its students and professors, its masjid and all, in the deep abyss of time. ${ }^{1}$

1 For Fìrūz-Shāhī-Madrasah, vide Barnī's Tārīkhi-Fìrūz-Shāhī (Bibl. Indica), pp. 562-566. 


\section{Chapter \\ The}

Tughlaq

Dynasty:

Firūz.

\section{PROMOTION OF LEARNING}

We notice that all the colleges founded by Fìrūz Shāh had masjids attached to them, and were most probably of the type indicated by the Fīrūz-Shāhī-Madrasah; and religious training and pursuit of the Muslim faith were essentials of the academic life of the residents of those colleges. Consequently, the residence and education of a Hindu youth in these madrasahs were quite out of the question. However, we find that the Hindus were being appointed to important Government offices, as, for instance, the two singularly efficient Hindu administrators, Khāni-Jahān, father and son, to whom Fīrūz Shāh virtually abandoned all authority; and the performance of the duties of those offices required a knowledge of the foreign languages such as Persian and Arabic. Similarly, we find the Muhammadans attaining proficiency in the Indian languages, as the following fact will show: the Ràjā of Nagarkoṭ was conquered by Fìrūz Shāh in a battle, but was restored to his dominions. About this time, the people of the place told Finuz that the idol which the Hindus worshipped in the temple of Nagarkoṭ was the image of Naushābāh [the wife of Alexander the Great ?], and that the Greek conqueror had left the idol with them. The name by which the idol was known at the time of the contest was Jawālàmukhì. In the temple of this idol was a fine library of Hindu books consisting of I300 volumes. Fīrūz ordered that some learned 


\section{THE TUGHLAQ DYNASTY}

Hindus should be sent there for translating a few

books. A celebrated poet of the period, named

A'izzuddin Khalid Khānī, was ordered to translate one of these books from verse into Persian prose, and when it was finished the Sulțān gave it the title of Daläili-Fìrüz-Shähi.'.

So both the Hindus and the Muhammadans were gradually learning languages-the former, of the ruling race, and the latter, of the subject people. It is not, however, known whether the colleges of the Hindus or the Muhammadans made any provision for the teaching of the alien languages, or whether they had to learn them in private.

In the reign of Fìrūz, there flourished many learned men, philosophers and jurists, some of whom were ${ }^{2}$ :-

Maulānā 'Ālim Āndapathī, the author of a lengthy and copious work on law and religion ;

Maulānā Khwājagī, the preceptor of Qāzị Shahābuddīn Daulatābādī ;

Maulānā Aḥmad Thānīsvarī and Qāẓ̂̄ 'Abdul Muktādir Shanihī, the latter of whom, besides possesșing vast knowledge, could compose excellent poetry, his Arabic verses surpassing his Persian.

1 Tärïkhi-Firishtah, Elliot vi, p. 227 ; Tabaqäti-Akbari, MS. in ASB, p. 93 ; Arch. Survey Report, vol. v, pp. 166, 167.

${ }_{2}^{2}$ 'Abdul Haqqq Haqqī Dihlawī, Elliot vi, pp. 487 ff.

65 


\section{Chapter

'A'inul-Mulk was the author of a popular work named 'A'inul-Mulkì.'

A striking provision made by Sulțān Fīrūz is another proof of the generosity of the monarch. No age is without a few educated and learned men who feel painfully their eternal want of pence by being out of employ or otherwise. Some of them out of shame would not make their necessities known, and so the Sultan gave an order to the kutwāl and the district officers under him that they should bring before the Emperor, after making inquiries about them if necessary, such of them as were in want; and these men of letters were provided for in the Government establishments. ${ }^{2}$

The tomb of this distinguished monarch was built, according to Sayyid Aḥmad Khān, in the year 792 A.H. (I389 A.D.) by Nașiruddin Tughlaq Shāh, in the village of Hauz Khāṣ. At the side of its north recess is a narrow pointed arch which led into a madrasah. Adjoining this long range of buildings, to the north, are the remains of the coilege of Fīrūz Shāh on the southern side of the Hauz Khāṣ or Hauz 'Alā'ī, described by C. Stephen.

The brilliant reign of Fìrūz Tughlaq was

1 'Afif's Tärīkhi-Fìrūz-Shāhī, Elliot iii, p. 369. 'Abdul Qadìr adds a few other names, e.g. Maulānā Mazhar Karra, Qāzĩ 'Ābid, etc., pp. 339-34I ; Muntakhabul-Tawärīkh, vol. i, (Ranking).

${ }_{2}$ 'Afîf's Tärīkhi-Fìrūiz-Shāhi, Elliot ii, p. 355 . 


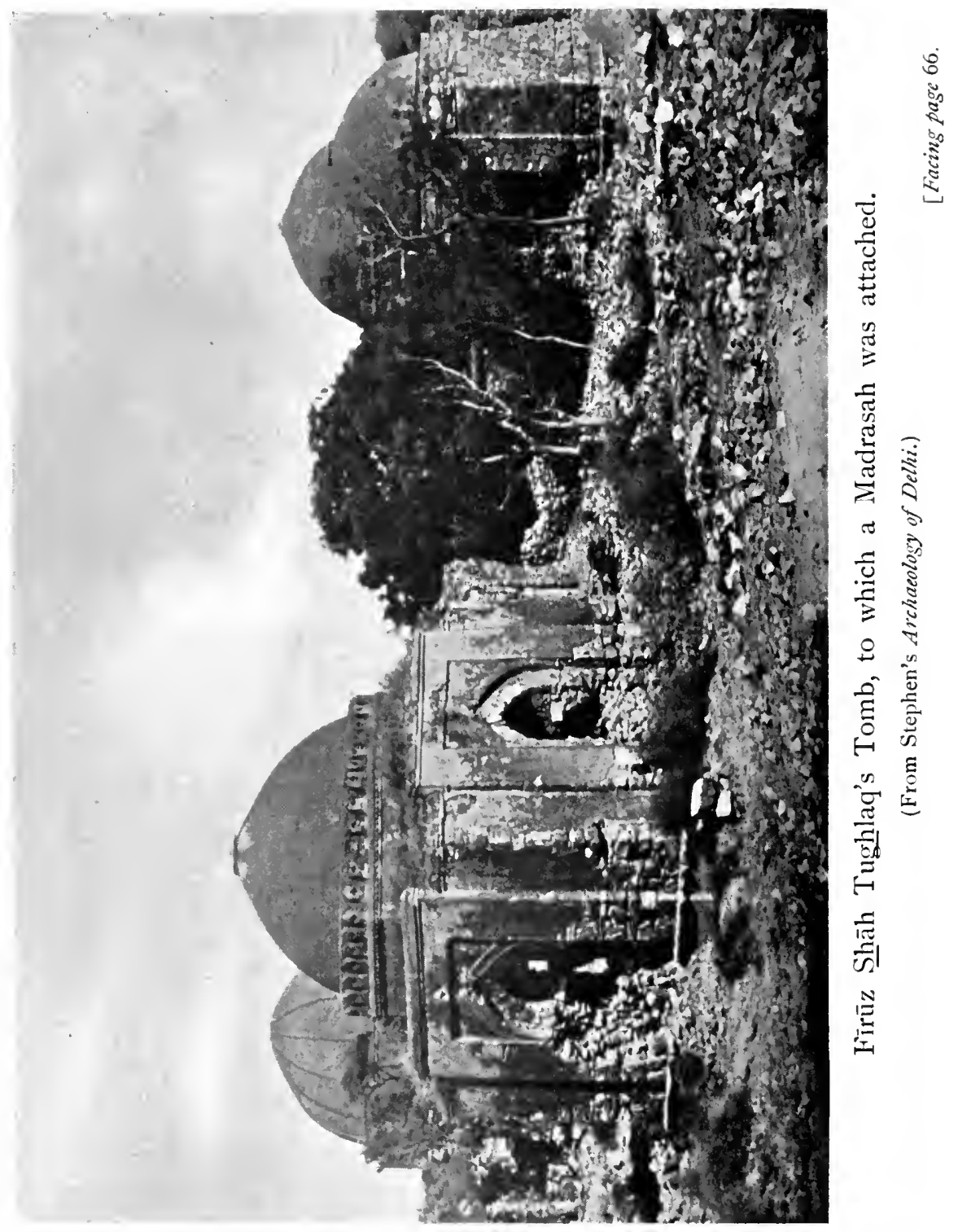




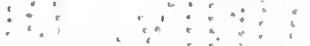

$\therefore \quad \vdots$\begin{tabular}{c}
0 \\
\hdashline
\end{tabular} 


\section{THE TUGHLAQ DYNASTY}

followed by the dark period covered by the three successive short reigns of Ghiyāșuddin II, Abu Bakr, ánd Nașīruddīn.

The next reign of Mahmüd Tughlaq was rendered gloomy by the formidable invasion of Tìmūr, who came as a tornado sweeping away all that fell in his way. Many a flourishing town was depopulated, and instead of the living inhabitants their dead corpses lay about in the streets. The people in alarm fled far away from their homes at the approach of this enemy of India, so that all the places through which he passed became deserts. Delhi, once the queen of Indian cities, was given up to sack and conflagration for five continuous days. The pillage extended even up to Hardwar.

Tīmūr, however, was not without some literary traits. During the siege of the town of Lonī, he ordered the houses of the Sayyids, Shaikhs, and learned Musalmāns to be preserved, and this was done, ${ }^{1-a}$ concession bespeaking the literary vein that ran through his stern Tartar character and also manifested itself in his practice of keeping company with learned men, even in his military expeditions. $^{2} \quad \mathrm{He}$ is the reputed author of an autobiography, Malfiuzäti-Timuivì, showing a partiality for writing memoirs, which characterized almost

1 Malfūzāti-Tìmūrì, Elliot iii, p. 433.

2 Ibid., Elliot iii, p. 390. 


\section{Chapter}

Timür.

\section{PROMOTION OF LEARNING}

all his descendants, e.g. Bābar, Jahāngīr and others.

The Memoirs gives us a description of Tïmūr's education in his infancy. When he attained his seventh year, his father took him by the hand and led him to a school, where he was placed under the charge of a tutor named Mullā 'Alī Beg. The Mullā wrote the Arabic alphabet on a plank and placed it before the infant Tīmūr, who considered the copying of it as an amusement. In his ninth year, Timūr was taught the daily service of the mosque. ${ }^{1}$

Tìmūr was thus far unlike his ancestor Changīz Khān, who scattered the Qur'ans found in the Jāmi' Masjid at Bukhārā and used the chests that contained them as troughs for his horses, compelling the scholars, Sayyids and priests to serve him as grooms by taking charge of the quadrupeds.2

It is said that Shāh Rukh, the son of Tĩmür, came by the Persian original of the Jämiul-Tawairikh belonging to Uljaitu Khān, the Sulțān of Persia.

1 Stewart's Malfūzāti-Tìmūin̄, p. 2 I.

2 Tārikhhi-Fahān-Kushāa, by 'Alāuddīn Juwainī, Elliot ii, pp. $387,388$.

An amusing story is related of Timūr, that he used to station the many learned men that accompanied him in his military expeditions behind the ladies in times of danger, for Timūr's opinion about the courage of literary men was not very complimentary to them.-

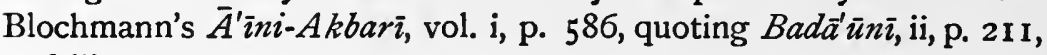
and iii, 312. 


\section{TĪMŨR}

The author of the work spent about 60,000 dinars in the transcription and binding of his writings and a considerable sum for copying and disseminating them both in Arabic and Persian in the most famous cities of the Muhammadan world. ${ }^{1}$ Shāh Rukh possessed a literary taste, and the story shows that a very large sum being spent on the transcription and get-up of a manuscript has its early precedents.

Tìmūr built a college in Samarqand, where he ordered one Sayyid Barakat to be buried after his death. ${ }^{2}$ Over and above this college

"he added richly endowed academies to the stately mosques of his erection, and for the encouragement of learning he established many libraries and pious foundations, which exist to the present day. That he knew how to value poets and scholars is proved by his dealings with Hāfiz and Ibn Khaldūn." ${ }^{3}$

Tìmūr's bodily remains after his death found their interment amid a literary environment, of which he was fond when alive.

"Muhammad Sulțān Mīrzā, the son of Jahāngīr Mìrzā and grandson of Tìmūr Beg, founded a college just as you go out of the stone fort of Samarqand. The tomb of Tìmūr Beg and the tombs of all such of the descendants of Timmūr Beg as have reigned in Samarqand are in that college." 4

After the death of Sulțān Fīrūz, the Royal Court almost ceased to be a centre of culture for more

1 Tārizkhi-Wassā $f$ and Rauzatul-Șafā, Elliot iii, p. 16.

2 Shāh-Fahän-Nāmah, by Ámin Qazwīnī, MS. in ASB, leaf 42.

${ }^{3}$ Noer's $A k b a r$, vol. i, p. 129.

${ }^{4}$ Erskine's Memoirs of Bābar, p. 50. 
than half a century. The political change introduced no change in this respect. Delhi and its surrounding provinces became scenes of war and bloodshed, and the commotion in the heart of the empire agitated the whole country. The places through which Tìmūr had passed sustained injuries which were not easy of reparation. Delhi and Fīrūzābād had most to lose, and they did lose much.

[NOTE.-With regard to the knowledge of Sanskrit among the Muhammadans of this period, Mr. Elliot says that in the library of Nawāb Jalāluddaulah at Lucknow, there is a work on astrology translated from Sanskrit into Persian in Fìrūz Shah's reign. There is also another work on the veterinary art called Kurrutul-Mulk, translated from the Sanskrit original styled Sălotar. Without any allusion to this work, another on the veterinary art entitled Sälotariz, the Sanskrit original of which is said to have comprised 16,000 slokas, was translated in the reign of Shāh Jahān by 'Abdullāh Khān Bahādur Fìrūz Jang. This work of Shāh Jahān's time is more than double the size of the other (see Elliot v. 573, 574).

Both Sälotar and Sälotarī are, I suppose, corrupt forms of Śälihotra, a Sanskrit treatise on the veterinary art.] 


\section{CHAPTER VI. \\ The Sayyid Dynasty.}

THE first two Sayyid kings, viz. Khiẓr Khān and Mubārak, following in the footsteps of the first three Tughlaqs, gave effect to their ambitious design of building towns. Khiẓr built Khizrābād after his own name, and adorned it with some beautiful edifices, while the latter did not live to complete his Mubārakābād, owing to his assassination. ${ }^{1} \quad$ The reigns of these two Sulțāns were short, as were also the two following. The last Sultān, Sayyid 'Alāuddīn, lived in Badā'ūn for about thirty years after Bahlül had wrested Delhi from him.

"In this ancient city of Badā'ūn, many princes of the Pathān Dynasty kept their Courts for a series of years during the reign of that dynasty of Hindustan. There, as in many parts of Cuttair, are to be seen the remains of magnificent edifices, palaces, gardens, mosques, colleges and mausoleums." ${ }^{2}$

So within roo miles of Delhi there had arisen another centre for diffusion of education, containing numerous colleges which supplemented the educational works of Delhi and Fĩrūzābād.

1 Garcin de Tassy's transl. of Sayyid Ahmad, pp. 29, 30.

2 Francklin's Shāh 'Älam, p. 57. 


\section{CHAPTER VII. \\ The Lūdí Dynasty.}

DelHi was the capital of the next Sultạn, Bahlūl, during whose reign a new city which was to play an important part in the future history of the Muslims in India came into being. Agra was at this time founded by Sultān Bahlūl ${ }^{1}$ and it made so rapid a progress that within four or five decades, it competed on equal footing with the ancient capitals. But to return to Bahlūl :

This Sultān was certainly not a man of great literary acquirements, but he was fond of the company of learned men, whom he rewarded according to their merits. ${ }^{2}$ It was with the advent of this Sulțān that there returned peace and order, and along with them greater cultivation and encouragement of letters by the State. It appears from the $M a^{\prime}$ assiriRahimi $\bar{\imath}$ that he built some colleges. ${ }^{3}$

The Sultān studied with much care the Muhammadan law, with which he made himself well

1 Calcutta Review (Keene's article, "Mediaeval India "), lxxix, p. 71 (1884).

${ }^{2}$ Ferishta vol. i, p. 562 ; and 'Abdullāh's Tärikhi-Dä'üdì, Elliot iv, p. 436 .

3 Md'àsiri-Rahimìi, MS. in ASB, leaf 133 . 


\section{THE LODI DYNASTY}

acquainted, as also the best institutes for the able conduct of his government, and was much helped in the practical dispensation of justice and the discharge of his royal duties by the knowledge thus acquired. The reputation which this monarch enjoyed for his impartial justice was no less due to his innate virtue than to these studies. ${ }^{1}$

Sultān Bahlūl was succeeded by his son Sikandar. A very important event of his reign is the transference of the capital from Delhi to Agra. ${ }^{2}$ This new city now became, with the acquisition of this dignity, an important place in every respect. It began to draw towards itself the centre of gravity of the learned world, which had hitherto been at Delhi and Fīrūzābād. Sulțān Sikandar was himself a poet, highly appreciated literary merit, and gave great encouragement to learning. ${ }^{3}$ He occasionally composed verses under the pen-name of Gulrukh. He used to submit his verses to Shaikh Jamãl, the author of the Siyarul-'Arifin for his opinion. His diwān is made up of eight or nine thousand couplets. ${ }^{4} \mathrm{He}$ insisted that all his military officers should be educated. This gave a new character to the profession of arms, in which

${ }^{1}$ Ferishta vol. i, p. 562; and 'Abdullāh's Tārizkhi-Dä'üdì, Elliot iv, p. 436.

${ }^{2}$ Calcutta Revierw, lxxix, p. 7 I.

${ }^{3}$ Ferishta vol. i, pp. 581, 587, 589.

4 Muntakhabul-Tawärikhh, vol. i (Ranking), 429. 
military virtues had to be combined with literary qualifications. ${ }^{1}$

Sikandar, though liberal in these respects, was a bigoted Musalmān. While at Narwār, he broke down many Hindu temples and built mosques in their place; and we hear of a college being established there at this time wherein he placed many holy and learned men. " "He entirely ruined the shrines of Mathurā, and turned the principal Hindu places of worship into caravansarais and colleges." 3

The Sultān was fond of hearing disputations on religious subjects, in which many learned men took part. One disputation, however, was marred by a most cruel exhibition of the Sultān's religious zeal, which, fanned by his learned co-religionists, led to the decapitation of the Hindu disputant who maintained the opposite side. This Hindu, named Budhan, professed the doctrine similar to that preached by Kabir, viz. that all religions, whether Hindu or Muslim, were equally acceptable to God, if followed in sincerity. The monarch ordered the most learned men in his empire to assemble and argue with the Brăhmana. The following learned men were brought to

1 Ferishta vol. i, pp. 581, 587, 589 .

2 Ibid.

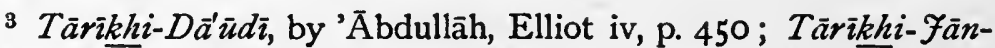

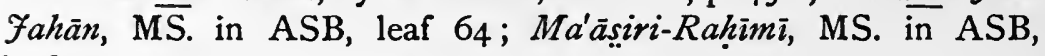
leaf I 32 . 


\section{THE LODI DYNASTY}

Sanbhal, where the discussion was held, and where the Sultān was present for the time being :-

Miyān Qādir bin Shaikh Rajū,

Miyān 'Abdul Ilyās and

Miyān Allāhdādī

\} of Tulumba,

Sayyid Muḥammad bin Sayyid Khān of Delhi, Mullā Quṭbuddīn and

Mullā Allāhdād Șālị̣

\} of Sarhind,

$\left.\begin{array}{l}\text { Sayyid Amān, } \\ \text { Sayyid Burhān and } \\ \text { Sayyid Ahsan }\end{array}\right\}$ of Qanauj.

Sayyid Aḥsan

Besides these, there were also present those erudite men who usually lived at the Sultaan's Court, such as Sayyid Sadruddin of Qanauj, Miyān 'Abdul Raḥmān of Sīkrī, Miyān 'Azīzullā of Sanbhal. ${ }^{1}$

The Hindu disputant boldly argued and refused to apostatize when his opponents in the discussion appealed to the King as their last argument, of which the only alternative was immediate execution. The brāhmana, who had the courage of his opinion, welcomed the latter.

Sikandar's reign is remarkable for the fact that " the Hindus for the first time applied themselves to the study of Persian," 2 and the origin of the

1 Ferishta vol. i, pp. 576, 577 ; see also Tärīkhi-Fän-Fahän, by Jān Jahān Khān, MS. in ASB, leaf 63 .

"Keene's "Mediaeval India," Calcutta Review, Ixxix, p. 7 I. Professor Blochmann remarks, in the Calcutta Review, civ, "A 


\section{PROMOTION OF LEARNING}

$\mathrm{Urdu}^{1}$ or Hindustani language, which dates from this period, tells us that there must have been intercourse between them and the Muslims. ${ }^{2}$ We have noticed that such intercourse began long ago, and there were not wanting stray cases of Hindus prosecuting studies of the Muhammadan languages. The present period marks a larger development of the movement which had before been only in its inception. Ferishta also records that " the Hindus, who had hitherto never learned Persian, commenced during this reign to study Muhammadan literature." 3

'Abdullāh records the following account of a peculiar habit of Sulțān Sikandar:-

"Seventeen accomplished and learned men of tried merit were constantly with him in his private apartment. After midnight, he

Chapter from Muhammadan History": "The Hindus from the sixteenth century took so zealously to Persian education that before another century had elapsed they had fully come up to the Muhammadans in point of literary acquirements."

1 "The name Urdu is of Turkish origin and means literally 'camp.' But the Mughals of India restricted its use to the precincts of the Imperial camp, so that Urdū-i-Mu'allā (high camp) came to be a synonym for new Delhi after Shāh Jahān had made it his permanent capital. The classical languages of Arabia and Persia were exclusively devoted to uses of State and religion; the Hindus cherished their Sanskrit and Hindī for their own purposes of business or worship; while the Emperor and his Mughal courtiers kept up their Turkish speech as a means of free intercourse in private life. Out of such elements was the rich and growing language of Hindustan formed, and it was yearly becoming more widely spread."-Keene's Mughal Empire, p. 6.

2 Keene's "Mediaeval India," Calcutta Review, lxxix, p. 74.

3 Ferishta vol. i, p. 587. 


\section{THE LODI DYNASTY}

was in the habit of calling for food, when these seventeen learned men, after washing their hands, seated themselves in front of the Sultān, who was himself seated on the couch. A large chair was then brought close to the bed and the different dishes placed on it, and the Sultan commenced eating. Food was also placed before his seventeen companions, who were, however, forbidden to partake of it in his presence. When the King had finished, they carried their plates away to their houses and ate there." 1

Under the auspices of Sikandar, the writing, translation, and compilation of a number of books took place under his orders; the Argar-mahäbedak (or the science of medicine and treatment of diseases) was translated and received the title of Tibbi-Sikandari. This book, 'Ābdullāh says, was the foundation of the practice of the physicians of Hind, and was thus brought into general use. ${ }^{2}$ The WäqiatiMushtāq $\bar{\imath}$ adds-

"Miyān Bhudh succeeded to the late Khawās Khān and was confirmed in the dignity. He got together fine caligraphists and learned men, and employed them in writing books on every science. $\mathrm{He}$ brought books from Khurāsān and gave them to learned and good men. Writers were continually engaged in this work. He assembled the physicians of Hind and Khurāsān, and, collecting books upon the science of medicine, he had a selection made. The book so compiled received the name of Tibbi-Sikandari, and there is no work of greater authority in India." 3

During Sikandar's reign, men of learning from Arabia, Persia, and Bukhārā, as well as those of India, were induced by the Sulțān's favours and

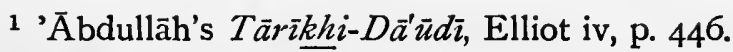

2 Ibid., Elliot iv, p. $45 \mathrm{I}$.

3 The Wāqiāati-Mushtāqī, by Rizqullah Mushtāqī, Elliot iv, p. 45 I $n$. 
encouragement to take their residence at Agra, the new capital, ${ }^{1}$ and the nobles who had the general direction of affairs in the Sultān's Government bestowed lands and other rewards upon them, pursuant to the Sultān's orders. The study of belles lettres was much encouraged by the monarch. ${ }^{2}$

While dwelling on the literary encouragement by the Emperor, we must not ignore the generosity of a particular noble of the time, named Masnād 'Alì Husain Khān. He was very charitable, and if any one getting allowance from him died, it was given to any relation of his that survived, and even if there were none but the wife, she was made to adopt a son, whom the noble sent to school and taught archery and riding. ${ }^{3}$

The daily routine of the theological study of another noble of Sikandar's throws light on the rigid way in which those studies were sometimes prosecuted. He used to read seventeen divisions of the Qur'an every day, all the while standing, until the task was finished. To read one of the takmilas of Ghauș-ul-Saqalin and the whole of Hiṣn-i-Hașin was also among his daily duties. ${ }^{4}$

Ibrāhīm Lūdì was not at all like his father

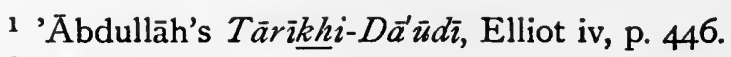

2 Ibid., Elliot iv, 450.

3 Wāqi'āti-Mushtāài, by Riẓqullah Mushtāqī, Elliot iv, p. 538.

4 Ibid., Elliot iv, p. 540. 


\section{THE LODI DYNASTY}

Sikandar. The fate of India reached a crisis in his reign, for the line of Sultanns under whom she would attain to the greatest prosperity would now commence. 


\section{CHAPTER VIII.}

The Minor Muslim Kingdoms.

WE have thus far dwelt upon the contributions made by the Pathān kings towards the progress of Muhammadan education and learning in India. But Muslim culture was not promoted by the Delhi kings alone. All over India there sprang up many a small kingdom which was making its own contribution to the general progress of Islāmic learning in the country; and an account of Muhammadan education of the period would be incomplete without a survey of the achievements of those smaller kingdoms apart from the work of the paramount power enthroned at Delhi.

\section{The Bahmanì Kingdom.}

$$
\text { (I 347-I } 526 \text { A.D.) }
$$

Some of the kings of the Bahmani kingdom were great patrons of letters, and one of them was 1347-58 A.D. almost as great in literary enterprise as Sultān Fìrūz Tughlaq of the Imperial dynasty. The founder of the Bahmani House, however, was not much noted either for his literary 


\section{THE MINOR MUSLIM KINGDOMS}

accomplishments or for his literary encouragement.

But he knew Persian, and took care for the education of his sons. We learn that the Bustann of Sa'di was a favourite book included in the course of study of the princes. ${ }^{1}$

At the time of Ferishta, it was the general belief that Hasan Gangu Bahmani was the first Brāhmaṇa who accepted service under a Muhammadan prince, and that before his time the study of the Vedas and the duties of religion were the Brāhmanas' only pursuit. Though as physicians, astronomers, metaphysicians or historians, they sometimes mixed with the rich and powerful, they never consented to take regular service. The acceptance of office by Gangu marks the period whence the management of the revenue was invariably entrusted to them by all the Deccan kings. ${ }^{2}$

Mujāḥid Shāh Bahmanī, who ruled some twenty years after Hasan Gangu, was noted for the fluency

1 Mahmund, the youngest prince, being questioned by his father one day, replied that it was the Bustann that he was then reading with his tutor (Ferishta vol. ii, p. 296). Silsilahi-Āșafiyah (vol. iii, p. I3I), quoting Mullā Dā'ūd Bīdarī's Tuhfatul-Salātīn gives an interesting account of a son of $D^{\prime} \bar{u}^{\prime} \mathrm{Sh}$ Sha, who used to teach students three days in the week, viz. on Monday, Wednesday and Saturday. He was very fond of these books: Zähidi, SharhiTazkirah and Tahriri-Uqlidas (Euclid) in mathematics; SharhiMaqāsid in theology; and Mutawwal in rhetoric; and made them the course of study of his pupils.

2 Fierishta vol. ii, p. 292. 
with which he could speak the Turkish language ${ }^{1}$ but his successor had a better literary equipment, 1375-78 A.D. and made himself famous by his literary 1378-97 A.D. encouragement. This prince named Mahmūd Shāh Bahmanī was himself a poet and wrote some elegant verses. $\mathrm{He}$ was also proficient in Persian and Arabic, which he spoke fluently. He was a patron of learning, and many poets of Arabia and Persia came to his Court and partook of his liberality. Mìr Faizullah Anjū, it is related, presented the King with an ode, for which he received a thousand pieces of gold, and, in appreciation of his poetic power, was loaded with wealth and distinction before his retirement to his native country. ${ }^{2}$ The Sultān founded a madrasah in the Deccan in 1378 A.D., for the education of orphans. They were provided with board and lodging at Government expense, and learned professors were engaged for their tuition in the college. $^{3}$

The fame of this prince for his patronage of learning spread far and wide, and on the assurance given by the aforesaid Mīr Faizullah Anjū to Hāfiz., the Shirāzi poet of world-wide renown, that he would have a cordial reception at the Court and a

1 Ferishta vol. ii, p. 328.

2 Ibid., p. 347.

3 Tärikhi-Qandhāri-Dakhan, by Munshī Muhammad Amìr Hamzah, p. 44 . 


\section{THE MINOR MUSLIM KINGDOMS}

handsome reward if he came thither and also a safe conduct back, Hāfiz distributed away the presents sent him by Mạ̣mūd Shāh Bahmanī and embarked on a royal vessel that had arrived at Ormuz from the Deccan. But no sooner did it weigh anchor than a gale arose and the ship had to return to the port. The poet suffered much owing to the storm and abandoned the voyage, but wrote a few stanzas which he sent to Faizullah. When these were read out to the King, he was much pleased, and as a reward for Hāfiz gave a thousand pieces of gold to Muḥammad Qāsim Mashhadi, a learned man of Gulburgah, to purchase for Hāfiz those products of Ind that would be most acceptable to the celebrated bard. ${ }^{1}$

This prince was the father of the poor and helpless, and for the education of orphans established schools in several cities of his dominion, viz. Gulbargah, Bīdar, Qandhār, Ellichpūr, Daulatābād, Chaul, Dabul, and in many other places; and supplied them with ample endowments for their maintenance. $^{2}$

This good prince was given the title of Aristotle by the Deccanese for his wise administration.

Ghiyāṣuddīn Shāh and Shamsuddīn Shāh next succeeded, and were followed in their turn by the great Bahmanī king named Fìrūz. It was this

1 Ferishta vol. ii, pp. 347-349.

${ }^{2}$ Ibid., pp. 349, 350. 
prince whose literary enterprise can well bear comparison with that of his namesake of the 1397-1422 Imperial Dynasty of Delhi. $\mathrm{He}$ was A.D. perhaps more learned than the erudite Muhammad Tughlaq: he was a good linguist, and Ferishta records that in his harem there were ladies of various races, such as. Arabians, Circassians, Georgians, Turks, Europeans, Chinese, Afghans, Rajputs, Bengalis, Gujrātīs, Telinganese, Marhattas and others, with each of whom he could converse in her own language. ${ }^{1}$

$\mathrm{He}$ also utilized his linguistic attainments in his conversation with the foreigners who came to his Court. He had a very retentive memory, which enabled him to acquire his many literary qualifications. On Saturdays, Mondays and Thursdays, he used to hear lectures on botany, geometry and logic, generally during the day, but, if business intervened, at night. He was a good poet, and often composed extempore verses. He was well versed in many sciences and very fond of natural philosophy. Every fourth day he used to copy sixteen pages of the Qur'an before engaging in public business. He spent most of his time in the society of divines, poets, reciters of history, readers

1 Ferishta vol. ii, pp. 369, 370: " $\mathrm{He}$ could read the Bible. From this, it is probable he learned Hebrew from the Jews who had been settled on the Malabar coast for many ages."-Scott's Deccan, vol. i, p. 74 . 


\section{THE MINOR MUSLIM KINGDOMS}

of the Shāh-Namah and the most learned and

witty among his courtiers. He took much pleasure in these pursuits; so that they were prolonged up to midnight. ${ }^{1}$

Fìrūz used to send ships every year from the ports of Goa and Chaul to different countries particularly to invite to his Court men celebrated for their learning. This is a feature of literary ardour quite peculiar to him. It was his opinion that kings should draw around them the most learned men, in order that they might help them with information and advice. Of the many learned men assembled at his Court, we hear of Mullā Isḥāq Sarhindi, who was famous for his wit and scholarship. ${ }^{2}$

Fìrūz was a great lover of astronomy, and for accurate stellar observations caused, in 1407 A.D., an observatory to be built on the summit of the pass near Daulatābād. The work was under the supervision of the astronomer Hakim Husain Gìlānī, whose death put a stop to its completion. ${ }^{3}$

Sayyid Muhammad Gīsū Darāz had a great fame for his vast learning, and Fìrūz went to meet him. The King, with his natural keenness, could see through his learned veneer and found him deficient. However, the King's brother, Khān Khānān, had unstinted reverence for this Sayyid,

1 Ferishta vol. ii, p. 365.

2 Ibid., p. 366.

${ }^{3}$ Ibid., p. 388. 
and not only built a magnificent palace for him, but also spent a great part of his time in hearing his lectures. ${ }^{1}$

Ahmad Shāh Bahmanī followed the footsteps of his worthy brother, Fīrūz Shāh, showed great 1422-35 A.D. deference to the learned and

The King gave several towns, villages and extensive lands near Gulbargah in perpetuity to Sayyid Muhammad Gīsū Darāz, and built for him a magnificent college near Gulbargah. ${ }^{2}$ But he was unfortunately not very well disposed towards the Hindus, and, when he attacked Bījāpūr, destroyed several colleges of the Brāhmanas ${ }^{3}$ in the open country near the town.

The succeeding kings were not much noted for their literary enterprise or learning, until we reach 1463-82 A.D. Muhammad Shāh Bahmanī II. The education of this prince was under the supervision of Khwājahi-Jahān, who appointed adri-Jahān Shūstarī, a celebrated scholar of that age, as his tutor. The prince made considerable progress in his studies, so that next to Fìrūz Bahmani, he was the most learned king that ever wielded the sceptre in the Bahmani kingdom. ${ }^{4}$

A noteworthy event of this reign is the literary munificence of Maḥmūd Gāwān, the minister. He
1 Ferishta vol. ii, p. 388.
2 Ibid., p. 398.
3 Ibid., p. 402.
4 Ibid., p. 477. 


\section{THE MINOR MUSLIM KINGDOMS}

was himself a very learned man, a good writer both in prose and verse, and had few equals in his

knowledge of mathematics. The Rauzatul-Inshā and some poems from his pen are still to be found in a few libraries of the Deccan. He used to send every year valuable presents to several learned men in Khurāsān and 'Irāq, for which the princes of those countries bestowed honours upon him. Maulānā 'Abdul Raḥmān's letters to Maḥmud Gãwān have been incorporated into the volumes of his works, and a poem by the Maulānā was written in praise of the minister. Maḥmūd Gāwān had the honour of having his biography written by Mullā 'Abdul Karīm Sindī. ${ }^{1}$

His literary beneficence was, it is related, so widespread that there was scarcely a town or a city the learned men of which had not derived advantage from him. There are in the Deccan many remains of public works accomplished by him with his own resources, amongst which may be mentioned the famous college at Bĩdar, built by him two years before his death. ${ }^{2}$ Says Meadows Taylor-

"The noble college of Mahimūd Gāwān in the city of Bīdar was perhaps the grandest completed work of the period. It consisted

1 Ferishta vol. ii, pp. 5 I0, 5 I 1.

2 Ibid., p. 5 I0; Muntakhabul-Lubāb, by Khāfī Khān (Bibl. Indica), pt. II., p. 452 , tells us a story as to how the Imām of the Masjid attached to the madrasah escaped being struck by a thunder-bolt. 


\section{PROMOTION OF LEARNING}

dom.

of a spacious square with arches all round it, of two storeys, divided into convenient rooms. The minarets at each corner of the front were upwards of 100 feet high, and also the front itself, covered with enamel tiles, on which were flowers on blue, yellow and red grounds and sentences of the Qur'ān in large kūfic letters, the effect of which was at once chaste and superb." 1

The college had a mosque attached to it in order that religion might go hand in hand with secular learning. At the time of Ferishta, the whole college was as entire as if just finished, but nowadays it has lost much of its beauty through mutilation by an explosion of gunpowder, which took place when Aurangzib used it as a magazine and a barrack. ${ }^{2}$

1 Meadows Taylor's Hist. of India, p. 185.

2 Briggs' note: "After the capture of Bïdar by Aurangzib, in the latter end of the seventeenth century, this splendid range of buildings was appropriated to the double purpose of a powdermagazine and barrack for a body of cavalry, when by accident, the powder, exploding, destroyed the greater part of the edifice, causing dreadful havoc around. Sufficient of the work remains, however, even at the present day, to afford some notion of its magnificence and beauty. The outline of the square, and some of the apartments, are yet entire and one of the minarets is still standing. It is more than 100 feet in height, ornamented with tablets, on which sentences of the Qur'an in white letters, 3 feet in length, standing forth on a ground of green and gold, still exhibits to the spectator a good sample of what this superb edifice once was. The college is one of the many beautiful remains of the grandeur of the Bahmani and Burìd dynasties, which flourished at Bìdar; and they render a visit to that city an object of lively interest to all travellers, but particularly to those who may peruse this history."-Ferishta vol. ii, p. 510.

The explosion of the powder-magazine is by some attributed to an exasperated soldier, who, in order to avenge himself upon a comrade with whom he was quarrelling, cast the burning guls from 


\section{THE MINOR MUSLIM KINGDOMS}

The college was equipped with a library for the use of its students, containing 3000 volumes. ${ }^{1}$

These works of Maḥmūd Gāwān stand out as a brilliant example of what a single individual with his own unaided resources could achieve. He was imbued with a spirit of such great self-sacrifice as is rarely met with in a man. His income was very large, "equalling that of many kings," but his beneficence was so great that after his death only a small sum was left in his treasury. He lived the life of an ascetic, sleeping on a bare mat and using earthen utensils, thus combining plain living with high thinking.

Maḥmūd Shāh Bahmanī II.'s reign is a good example of the great extent to which the vitiated

his chìlam into a powder cell. Thevenot the traveller gives a different account. According to him, a faithful commander of the place took his stand in the college along with his army, and refused to submit to Aurangzib. When, however, a breach was made in the wall and signal given for the assault, then suddenly by the fall of a rocket or by the order of the commander, who preferred death to subjection, the magazine blew up at a moment when the roof was covered with the garrison who had assembled there for selling themselves as dearly as possible [Oriental Annual (1840), by T. Bacon, pp. I89, 190; see also Fergusson's Architecture at Bïjäpiur, pp. I 3 ff., and Thevenot's Travels into the Levant]. There is a picture of Gāwān's college in the Archaeological Survey of Western India, vol. iii, by Burgess (1875-76), but the one from the Oriental Annual, sketched by Meadows Taylor, has been reproduced in this work (see Frontispiece).

1 Ferishta vol. ii, p. 5 I4. Murtazā Husain says, in his HadĩqatulAqālìm, a modern work (MS. in ASB, leaf 39) that from Maḥmūd Gāwān's house, 35,000 books were obtained. 
taste of a king can spread its infection broadcast, so as to affect even those who have made education $1482-1518$ their profession. The king was much adA.D. dicted to the baser pleasures, and his Court became the resort of magicians and dancers from Delhi, Lahore, Persia and Khurāsān. The only kind of pleasure that could lay a claim to greater refinement was that afforded by the story-tellers and reciters of the Shäh-Nämah. The people caught the royal malady, which became so widespread and virulent that even "holy teachers quitting colleges retired to taverns and presided over the wine-flask, and reverend sages pawned their very garments at the wine-cellars." 1

The succeeding kings are not noteworthy from our standpoint. We should note here that the Bahmanī kings had a library at Ahmadnagar, which Ferishta visited. ${ }^{2}$

We shall conclude this account of the Bahmani kingdom with the remarks of a European gentleman who had occasion and opportunities for gaining detailed information and first-hand knowledge about the vanished glories of the kings of the Bahmani Dynasty as well as their remnants that still survive in the ruined monuments they have left behind-

"If we cannot compare the Bahmani kings with their European contemporaries from Edward III to Henry VIII, yet there can be

1 Ferishta vol. ii, p. 535.

2 Ibid., p. 297 ; Scott's Deccan, vol. i, p. 226. 


\section{THE MINOR MUSLIM KINGDOMS}

no doubt that high civilization according to the standard of $\mathrm{Mu}$ hammadanism existed. ... Education in Persian and Arabic literature was extended as much as possible by village schools, which were attached to mosques and endowed with lands sufficient for their maintenance. . . . The system tended as well to the spread of literature as of the faith of the ruling power, and its effects are still distinctly traceable throughout the wide extent of their dominion." 1

\section{The Kingdom of Bījāpūr.}

The name Bījāpūr is looked upon by some as a euphonized corruption of Vijaya Pura (city of victory), but according to another theory it is a different form of Vidyāpur (city of learning). The latter name, it is said, owes its origin to an old college $^{2}$ still existing there, the original endowments of which by the Chalukya Dynasty of Kalyān are commemorated upon large stone pillars hard by. The inscriptions are not of very great antiquity, one being of the Chalukya Dynasty (I 192 A.D.), and the other of the Yàdava (I 249 A.D.). The local tradition says that a band of Muhammadan fanatics who preceded the main Muhammadan army in the second invasion of Malik Kāfūr ('Alāuddīn's general) killed or drove away the Brāhmanas of the college, and occupied it. The story is not improbable, since there are traces, as Mr. Fergusson says, of similar occupation in other parts of the Deccan. It was

1 Fergusson's Architecture at Bījāpūr, p. I2.

2 Fergusson interprets Agrahār as "college." It literally means a royal donation of land to Brāhmanas. 
probably converted into a mosque by the garrison left by Kāfūr in Bījāpūr.

The college building, made of granite, is very extensive and the most venerable in Bijjāpūr, consisting of an oblong, set out with rows. It is threestoried, and is still wonderfully perfect, though necessarily out of repair. ${ }^{1}$

With the disappearance of Hindu sovereignty, Bījāpūr did not cease to be a centre of learning. The Muhammadans took the place of the Hindus and kept up its literary reputation.

'Ádil Shāh, the founder of the Muhammadan kingdom of Bījāpūr, was educated at Sava and r480-55ro had a good literary outfit. He was eloA.D. quent in speech, a good judge of poetical composition, and wrote both prose and poetry with elegance. He had a great taste for music, and his skill in it was superior to that of many a mastermusician of the time whom he encouraged to attend his court by handsome rewards. He could perform admirably on two or three kinds of instruments, and in his delightful mood sang extempore compositions. Many learned men were invited to his court from Persia, Turkistan and Rūm, as also several eminent artists, all of whom lived under the king's patronage. ${ }^{2}$

1 Vide Fergusson's Architecture at Bījāpūr, pp. 58, 60, 65, 66, where a detailed description of the college premises is found.

${ }^{2}$ Ferishta vol. iii, pp. 8, 30, 31. 


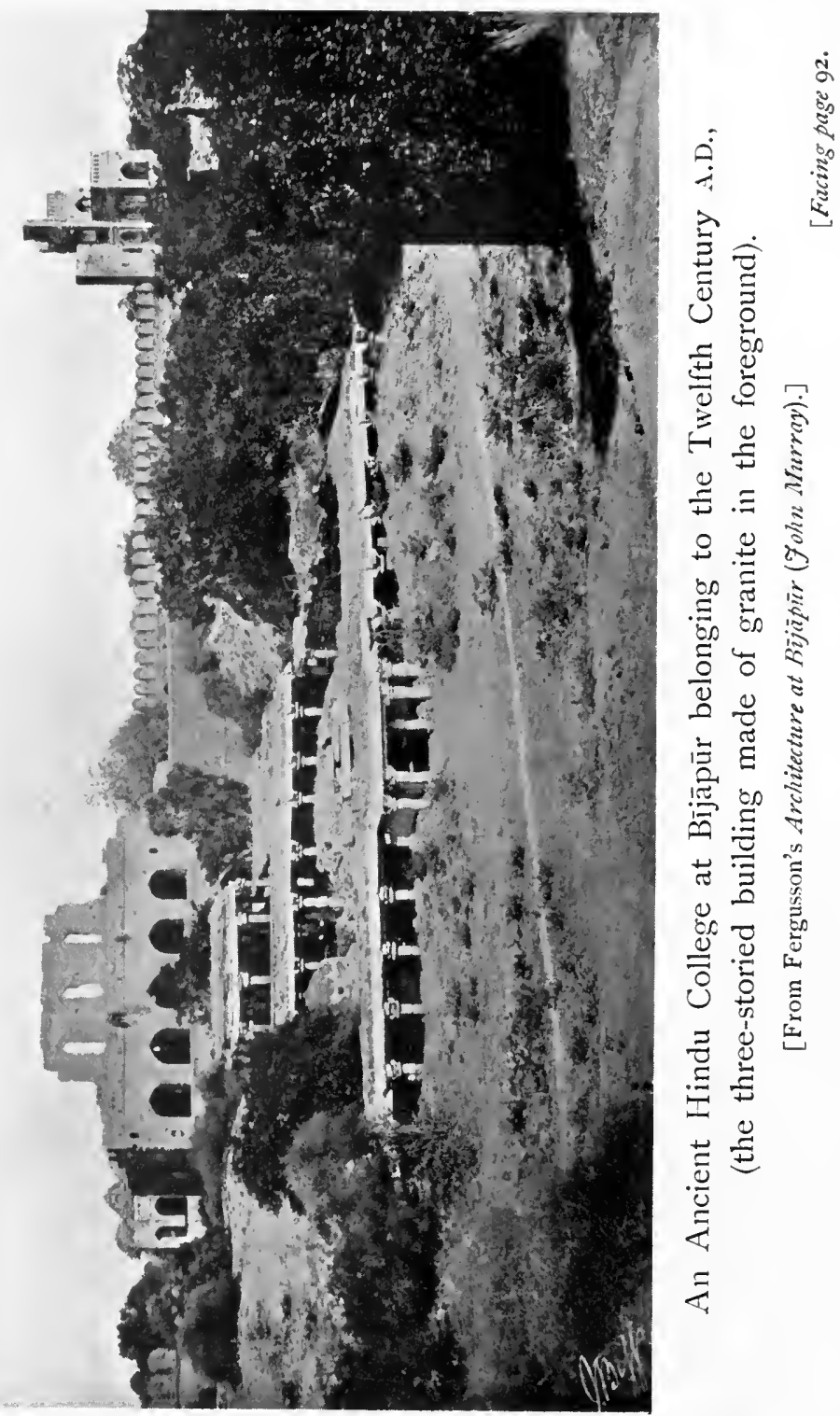


$\therefore \quad \therefore$ 


\section{THE MINOR MUSLIM KINGDOMS}

Ismā'il 'Ādil Shāh, the successor of 'Ádil, kept

up the reputation of his house by his literary refinements and proficiency in the fine arts. In music and poetry he was a great 1510-34 A.D. adept, and combined a skill in varnishing, arrowmaking and embroidering with his mastery in the art of painting. $\mathrm{He}$ was fond of the company of learned men and poets, a large number of whom was munificently supported at his court. He was a wit, and his brilliant humour often displayed itself in his conversation. He loved Turkish and Persian music and language more than the Deccanese. This bias was due to his being educated under the tuition of his aunt Dilshād, who by desire of his father kept him away from the company of the Deccanese. $^{1}$

One noteworthy fact of the reign of Ibrāhīm 'Ādil Shāh I. was that public accounts began to be kept in Hindi instead of in Persian, and many Brāhmanas were appointed in r534-57 A.D. charge of the accounts, so that they soon acquired a great influence in the government. ${ }^{2}$ In the reign of Yūsuf 'Ādil Shāh, the Hindus had also been admitted to the exercise of considerable powers in his revenue department. This was probably due to the fact of his having married a Hindu ladythe daughter of a Mahratta chieftain. ${ }^{3}$ This shows

${ }^{1}$ Ferishta vol. iii, p. $72 . \quad 2$ Ibid., p. 80. $\quad{ }^{3}$ Ibid., p. 31. 
how the Muhammadans while conquering the Hindus were at the same time being conquered themselves, and how the gradual linguistic intercourse was taking place.

A fact to be noticed in the reign of Ibrāhim 'Ádil Shāh II is that the great historian, Muham1579-96 A.D. mad Qāsim, the author of the TärikhiFirishtah, lived in his court.

A part of the royal 'Ādil Shāhì Library is still to be found at Bījāpūr in the Aș̣āri Maḥal. Mr. Fergusson tells us-

"Some of its books are curious and interesting to any one acquainted with Arabic and Persian literature. All the most valuable manuscripts were, it is said, taken away by Aurangzib in cart-loads, and what remain are literally only a remnant, but a precious one to the persons in charge of the building who show them with a mournful pride and regret." 1

3. The Kingdom of Aymadnagar.

Aḥmad Niẓām Shāh, the first King, was in his childhood taken prisoner by the army of Ahmad End of the Shāh Bahmani, who educated him with his r5th century. eldest son, Prince Mạmūd. The boycaptive was of exceptional ability, and with the facilities for study placed within his reach, he soon attained eminence in Persian and Arabic literature. ${ }^{2}$

1 Fergusson's Architecture at Bījäpiur, p. 75.

${ }^{2}$ Ferishta vol. iii, p. 190. 


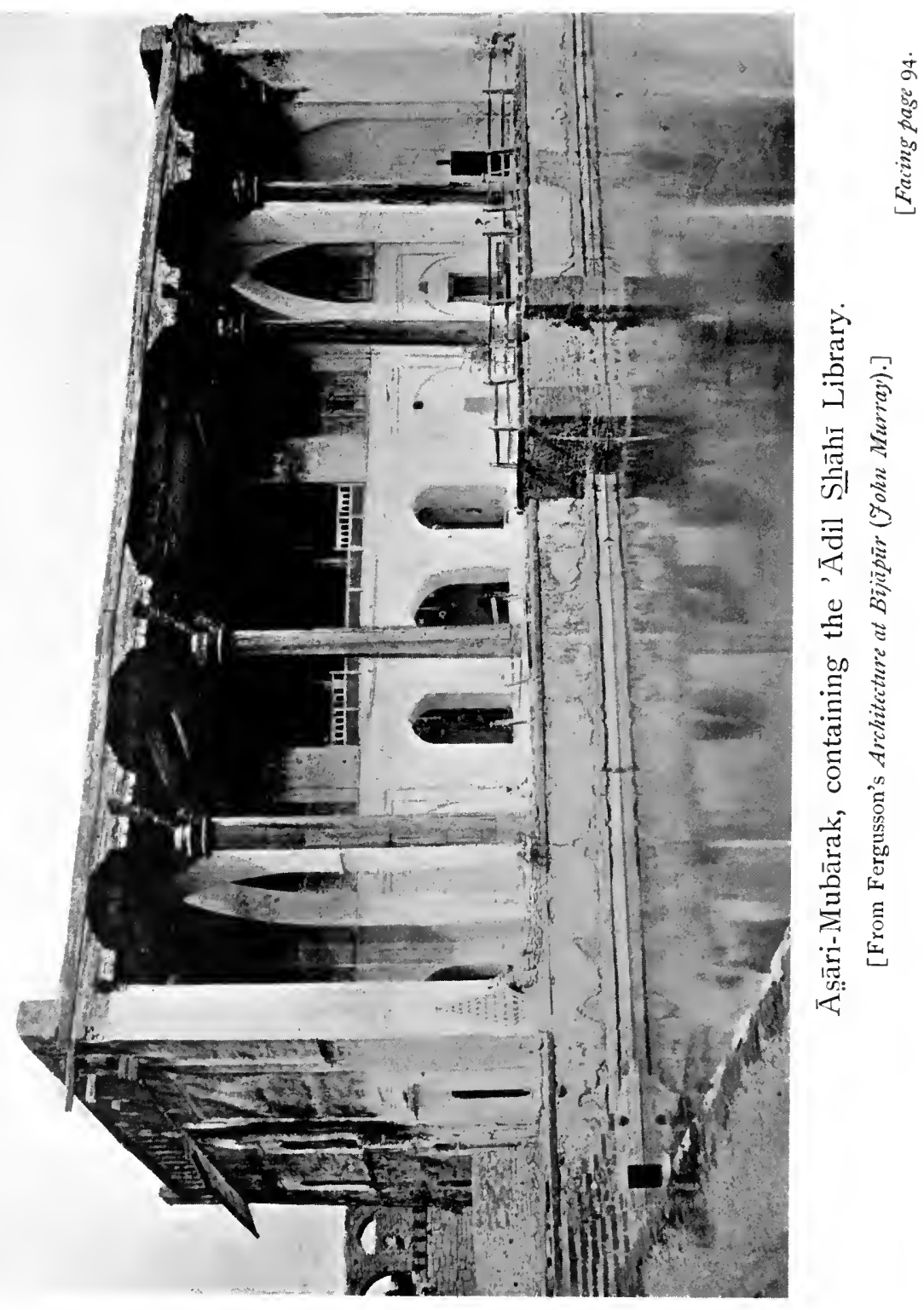




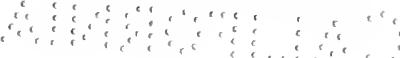




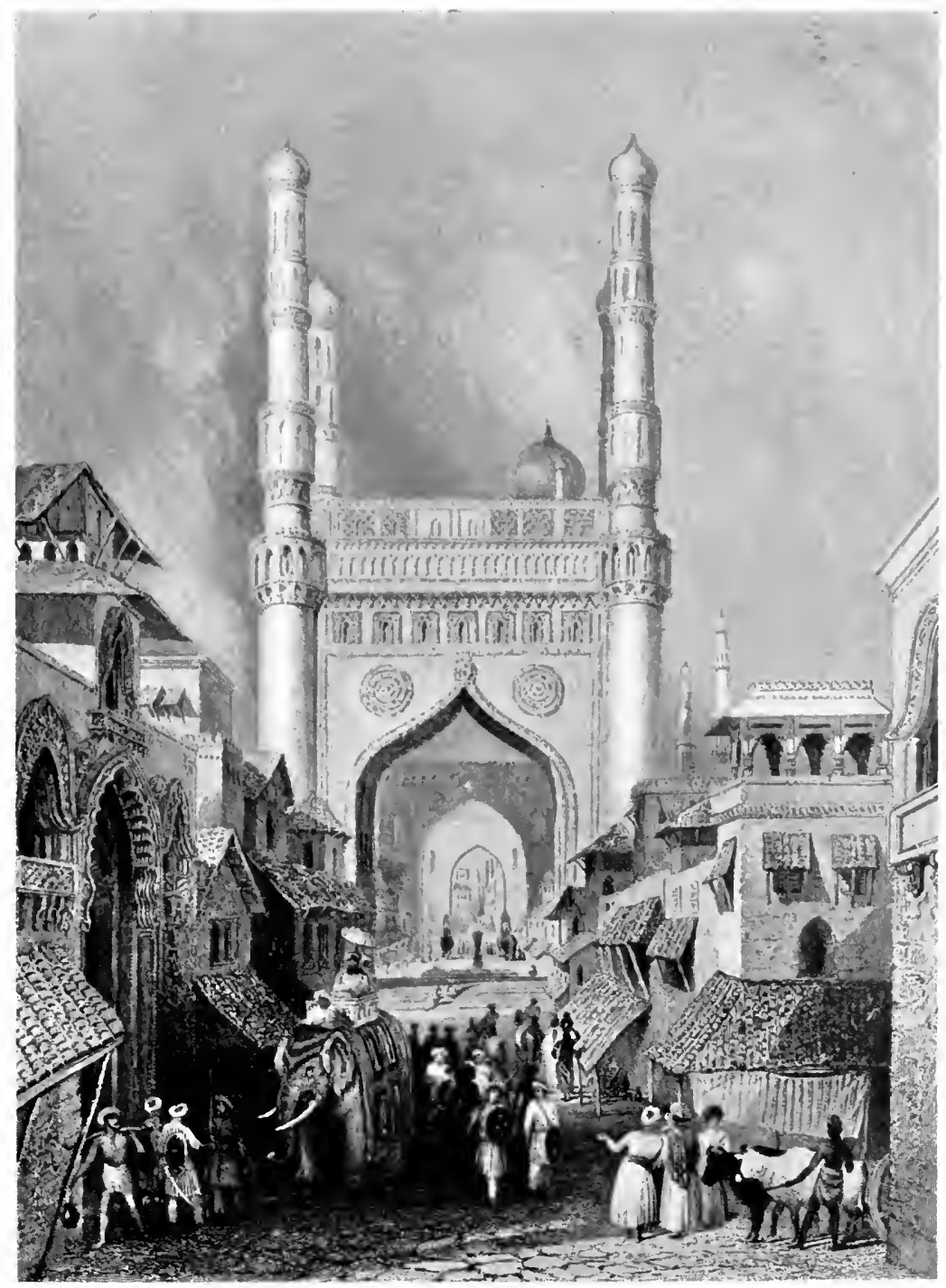

Chahār Minār at Hoaidarābād, containing a Madrasah, built I 59I A.D. (From the Oriental Annual, $18_{40}$.) 


\section{THE MINOR MUSLIM KINGDOMS}

In the reign of King Aḥmad Niẓām Shāh, the practice of single-stick was introduced by the king when a boy. He was much skilled in this Beginning of sort of sword play, and took much delight century. in the exercise. Accordingly, we are told, all men both high and low began to copy the prince, and " instead of colleges, as is usual in Muhammadan cities, schools for single-sword and wrestling were established in all quarters of the city of Ahmadnagar."

\section{The Kingdom of Gulkandah.}

In the royal dynasty of Gulkandah, the name of Muhammad Quli Quṭb Shāh stands high for his encouragement of education. In the End of the middle of Haidarābād, he built an elegant $\begin{gathered}\text { Ioth century } \\ \text { and begin- }\end{gathered}$ masjid and the Chahār Minār - the latter $\underset{\text { ning }}{\mathrm{r} \text { th. }}$. structure being a quadrangle with four arcades, each arch occupying the whole space between the minarets at its corners. Over the middle, there is a dome under which a fountain plays with its jets of clear water. Each minaret about 220 feet in height contains apartments for the use of the professors and students of the college there. It is one of the most splendid buildings in the city, and a brilliant specimen of Saracenic architecture. This college was seen by Thevenot the traveller, who visited India about I666 A.D., and has admired it in his

\section{${ }^{1}$ Ferishta vol. iii, pp. 206, 207.}


work. ${ }^{1}$ Besides this madrasah the king built several other colleges and public seminaries, all of which were properly furnished, and for which learned professors with liberal remunerations for their services were appointed. ${ }^{2}$ One of the colleges stood in the vicinity of Haidarābād. ${ }^{3}$

Over and above the bigger colleges, there were in Southern India the primary schools which were held in the houses of the masters. Shoberl gives some graphic details of these institutions :-

"The pupils sit cross-legged on a bench or on the floor. They write on paper with reed pens, or with tubes of some other kind. The paper mostly imported from China is not so good as that of Europe. It is smooth, very thin and easily tears.

"The Qur'ann," he further informs us, "is chiefly read by the Musalmāns who also study the Persian language. TTipū Șāhib, the last sovereign of Mysore, understood several oriental languages, and possessed a library enriched with all sorts of European and Eastern works." 4

\section{The Kingdom of Mālwa.}

Sulțān Maḥmūd Khiljī of the royal dynasty of Mālwa was a great promoter of learning and

1 Thevenot's Travels into the Levant, Part iii, p. 95.

2 Ferishta vol. iii, p. 452 ; Caine's Picturesque India, p. 464; Maulawī 'Abdul 'Aziz's 'Azizi-Dakhan, p. 20, gives the date of the establishment of Chahār Minār as 998 A.H. (I59I A.D.); see also Oriental Annual (1840), by T. Bacon, p. I68; and Fergusson's Architecture at Bījāpūr, p. 48.

${ }^{3}$ Ferishta vol. iii, p. 483 .

${ }^{4}$ Shoberl's Hindustan in Miniature, vol. iv, pp. 21 5, 216. 


\section{THE MINOR MUSLIM KINGDOMS}

literature. During the whole of his long rule for

over thirty years, he gave encouragement to learned men, so that Mālwa rose to be a great resort of literary men resort of literary men. Many distin- middle of the guished philosophers and maulānās not only came from other countries to the place but were also turned out by the many colleges that Maḥmùd founded in the different parts of his dominions. Mālwa, according to Ferishta, could bear a fair comparison with Shīrāz or Samarqand in literary excellence. ${ }^{1}$

One of the many colleges that owed their existence to this ruler stood in Mandu opposite to the Masjid of Sulțān Hüshang. It was in front of this college that he built a beautiful pillar seven storeys high after his return from a combat with Rānā Kumbha of Chitor. ${ }^{2}$

A very learned man of this time in Mālwa was Shaikh Chānd. ${ }^{3}$

Mahmūd was of literary tastes. He used to devote his leisure hours to hearing histories, and memoirs of kings of the world. ${ }^{4}$

In the reign of Grhiyãșuddin of Mālwa, we find that the education of the ladies in his harem was cared for. "Schoolmistresses" were ap- ${ }_{\text {}}{ }_{\text {A.D. }}^{60-1500}$ pointed to instruct them. ${ }^{5}$
1 Ferishta vol. iv, pp. 196, 197.
${ }^{3}$ Ibid., vol. iv, p. 213. N.K.T. has S. Jā'ilda.
4 Ibid., p. 234 .
5 Ibid., pp. 236, 237. 
The doms of Mālwa and Khāndīsh.

\section{PROMOTION OF LEARNING}

This king was "righteous and religious," but at the same time enjoyed much the pleasures of the world. It was his practice, we are told, to sleep every night with some thousand gold mohars under his pillow, which in the day he gave away to deserving people. ${ }^{1}$ In his harem there were seventy women who knew the Qur'an by heart and had to recite it while the Sultān was putting on his clothes, and continue it until he finished dressing. ${ }^{2}$

Bàz Bahādur of Mālwa, the contemporary of Akbar, was noted for his taste for music. In Mālwa, this art reached its height at this time and the king devoted himself entirely to its cultivation and encouragement, to the neglect of State affairs. This ardent follower of Orpheus had to pay the penalty for this neglect by losing his kingdom, which was conquered by Akbar. ${ }^{3}$

\section{The KingdoM OF KHĀNDİsh.}

Nāṣir Khān, the second sovereign of Khāndīsh, was fortunate in having Shaikh Zainuddin, the Last quarter disciple and successor of Burhānuddin, as $\begin{aligned} & \text { of the s4th } \\ & \text { century and } \\ & \text { begininging of }\end{aligned}$
his priest. They were men of great the 15 th.

repute in learning, being principals of the Madrasah at Daulatābäd. ${ }^{4}$ Burhānpür the capital

1 N.K.T. has " Ioo gold mohars."

2 Wäqi'äti-Mushtāqì, Elliot iv, p. 554.

3 Ferishta vol. iv, pp. 277, 278.

4 Oriental Annual (1840), by T. Bacon, pp. I I 8, I 19. 


\section{THE MINOR MUSLIM KINGDOMS}

of Khāndīsh had at least one madrasah. The city stands on the bank of the river Tāpti and the remains of the college were seen by the compiler of the Oriental Annual (1840). ${ }^{1}$

The kingdom of Khāndish during its existence as an independent principality found a patron of letters in Nāṣir Khān Fārūqī who influenced its destiny for about forty years. He invited learned men from many countries and gave great encouragement to the promotion of literature. ${ }^{2}$

7. The Kingdom of Jaunpūr.

While Khāndīsh was being thus raised to a high position in the literary world, Jaunpūr was becoming at the same time a great seat of learning under its famous king Ibrāhīm Sharqi i. ${ }^{3}$ About this time under the Sayyids, Western Hindustan was passing through an era of confusion and anarchy. It is therefore gratifying to notice that Jaunpūr reared its head as a tower of light, shedding its lustre far and wide in spite of the successive waves of tumult and disorder that threatened to engulf it every moment. It was here that Farid, afterwards called Shīr Shāh, received his education at one of its colleges about a century later, when Jaunpūr continued to be an educational centre. Farīd in a letter

1 Oriental Annual (1840), p. I12. ${ }^{2}$ Ferishta vol. iv, p. 286.

3 Ibid., p. 363. 
The

Kingdom

Jaunpür.

\section{PROMOTION OF LEARNING}

to his father wrote that it was a better place of instruction than Sasarām. ${ }^{1}$

Ibrāhīm Sharqī was a famous patron of literature and learning, to whom several books were dedicated by various authors. ${ }^{2}$ In his time, there flourished many learned men such as Qāzị Shahābuddīn Daulatābādī, who was called the "king of sages" by his contemporaries. After his demise, Maulānā Shaikh Ilāhdād Jaunpūrī made himself famous by his literary compositions. Another distinguished literary man was Zāhir Dihlawī, to whom a noble of the time of Sikandar Lūdi had given the title of $Z \bar{a}$ hir on account of his freshness of style. Maulānā Hasan Naqșhī, Maulānā 'Alī Aḥmad Nishānī and Nūrul Haqq were other famous literary magnates. ${ }^{3}$ Many books were written for him, e.g. Fatāwa-Ibrāhìm-Shāhì, Irshād, etc. ${ }^{4}$

“During Ibrāhīm's reign (I402-4O A.D.), the Court of Jaunpūr far outshone that of Delhi, and was the resort of all the learned men of the East." 5

During the reign of Fīrūz Tughlaq, the founder of the city, ${ }^{6}$ there lived in it many learned men

1 Ferishta vol. ii, p. 100.

2 Ibid., vol. iv, p. 363.

3 'Abdul Haqq Dihlawi, Elliot vi, pp. 487 ff.

- Ma'āsiri-Rahimmī. MS. in ASB, leaf $2 \mathrm{I}$.

5 Lethbridge's Topography of the Mughal Empire (transl. from the Latin of Laët), p. $53 \mathrm{n}$.

6 Jaunpūr was founded by Fīrūz Tughlaq (Gladwin's $\bar{A}^{\prime} i n i-$ Akbari, p. 321).

The date of its foundation according to the Tazkiratul-'Ulamā, IOO 


\section{THE MINOR MUSLIM KINGDOMS}

and professors for whom Fīrūz fixed liberal stipends. ${ }^{1}$

Sulțān Sikandar Lūdi was very cruel to the learned men of the city. After his conquest of Jaunpūr, he ordered the destruction of all the buildings of the Sharqi Nawābs of the place. At this, the learned men came to him and prayed for the cancellation of the order on the ground that there were many mosques which would be affected by his order. They expected that the reason shown by them would achieve their object and the whole order would be withdrawn. Sikandar, however, spared only the mosques, and the order remained in force in regard to the other buildings, including the madrasahs. ${ }^{2}$

About the middle of the I $5^{\text {th }}$ century, Bìbi Rājī, the wife of Maḥmūd Shāh (son of Sulțān Ibrāhīm) built a Jāmi' Masjid, a college and a monastery, and gave them the name of Namāzgāh. She also allotted stipends for students and professors. ${ }^{3}$

by Khairuddīn Ilāhābādī, MS. in ASB, leaf 3, is 772 A.H. (137 I A.D.). See J.I., p. 5.

1 Faunpūr-Nämah, by Khairuddīn Ilāhābādī, MS. in ASB, leaf 4 .

2 Ibid., leaf 30.

${ }^{3}$ Ibid., leaf 33. In this MS. as well as in its translation by Pogson whom Cunningham quotes, the date of erection of the buildings is 806 A.H. (1403 A.D.), which is evidently an error. The true date according to Cunningham is either 846 or 856 A.H., i.e. during the period of her husband's reign (vide Arch. Survey Report, vol. xi, p. I16). See J.I., p. 52. 
It is related of Mun'im Khān, Khān Khānān, that for the residence and tuition-work of the learned man Shaikhū, he built apartments near the big Jaunpūr Bridge, the inner portions of which were used by his pupils and the outer were let out. The rents thus derived met the expenses of the students. ${ }^{1}$

The Tazkiratul-'Ulamā and the Siyarul-Mulk as quoted in the Tazkira give us interesting details about this university-city, which throw a flood of light not only on the inner life of the learned men and students who lived there, but also on many other points. We learn that from the time of the foundation of the city, people from all districts of Hindustan, specially from the Subahs of Oudh and Ilāhābād, used to flock thereto for education. In the time of Sultān Ibrāhìm Sharqī, it was his capital, and here hundreds of madrasahs and masjids lay scattered, and scholars and teachers were granted altamgahs and jägirs in order that they might devote themselves to learning in complete freedom from material needs and anxieties. ${ }^{2}$ During Humāyūn's reign, Jaunpūr continued to enjoy its

1 Faunpūr-Nāmah, MS. in ASB, leaf 43. J.I., pp. $60 \mathrm{ff}$.

2 This feature is also noticeable in some of the Muslim Universities outside India, e.g. the Azhar University at Cairo, as also those at Baghdād, Cordova, Damascus, Nishāpūr, etc. (vide Encyclopaedia Britannica, I Ith ed.). The Mediaeval Universities of the Europeans seem to have differed from the Muslim Universities on this point (vide R. S. Rait's Life in the Mediaeval University). 


\section{THE MINOR MUSLIM KINGDOMS}

high reputation as a centre of learning, and re-

mained so through Jahāngir's reign up to the time of Shāh Jahān, who gave it the name of ShīrāziHind. It appears that up to the reign of $\mathrm{Mu}-$ hammad Shāh, it was the usual practice of Delhi emperors to send farmans to the hakims of Jaunpür in order that they might never be amiss in their duties towards the many students and professors in the city. Reports (Wäqiai-Nigar) ${ }^{1}$ had to be sent to them by the Reporter stationed at Jaunpür after carefully inquiring into the state of every madrasah. Fresh grants were made if any madrasah appeared from the report to require them. Princes and Amirs while passing by the city used to pay visits to its madrasahs and make donations to please thereby the Delhi Sultāns. About I 47 A.H. (I735 A.D.) Nawāb Sa'ādat Khān Nishāpūrī was appointed Subādār of Oudh, Benares and Jaunpūr. On one occasion he visited the city but felt insulted for the reason that the learned men of the place did not come to see him. To avenge this wrong, he gave orders for the confiscation of their stipends and jägirs. The orders were carried out, and a bad time set in for Jaunpūr. The students and professors were scattered and the madrasahs became empty. ${ }^{2}$ In I I87 A.H. (I774) Nawāb Āṣafuddaulah, at the instance of Mukhtaruddaulah,

1 Tazkiratul-'Ulamā, MS. in ASB, leaves $3 \mathrm{ff}$.

2 Ibid., leaves $3 \mathrm{ff}$. 
ordered the jägirs to be restored to their former holders, but one Ilāj Khān protested. Jaunpūr about this time came into the hands of the British. ${ }^{1}$

"Warren Hastings may have visited the city, Sir Eyre Coote certainly did, while Duncan's visit in 1788 is recorded in those volumes of Proceedings which are mouldering unnoticed on the record-shelves of the Commissioner and Collector of Benares. $\mathrm{He}$ writes too favourably of the site and laments the decay of the town, telling how it once was the seat of all Muhammadan learning, and the residence of many of their learned men in so much that it was known by the appellation of the Shirāz of India. Though no trace be now left of the schools but the story of their past fame, we have better ground than Mr. Duncan's for saying that this city was the Shìrāz or the mediaeval Paris of India. Fìrūz determined to make it a seat of learning worthy of his cousin's fame. Each of the princes of Jaunpurr prided himself on patronizing science, and the troubles which in the early part of the fourteenth century scattered the doctors of the ancient imperial city were eminently favourable to the rise of a school of learning in the peaceful and secure Jaunpūr. Even in Muhammad Shhāh's time, 20 famous schools existed in Jaunpurr of which now but the names are known-the founder of one having died in the middle of the fifteenth century, and another in the middle of the seventeenth century. Nor was scholastic learning only cultivated. Of the successful cultivation of the arts, let the noble masjids of Ibrāhim and Husain bear witness." 2

Like Jaunpūr, many a great Muslim University has now ceased to exist, leaving behind only a memory of its former glory. The days are past when the Indian Musalmān universities, as also those of Dimashq, Baghdād, Nishāpūr, Cairo, Kairawān, Seville, Cordova were thronged by thousands of

1 Tazkiratul-'Ulamā, MS. in ASB, leaves $3 \mathrm{ff}$.

2 Archaeological Survey of India (New Series), vol. i, (Sharqi Architecture of Faunpür), by Führer (1889), pp. 21, 22. 


\section{THE MINOR MUSLIM KINGDOMS}

students, when a professor had often hundreds of hearers, and when vast estates set apart for the purpose maintained both students and professors.

\section{Multān.}

Of the kings of Multān, the name of Husain Langā will be remembered for the impetus he gave to education by erecting many col- Third leges, in which were appointed the most quarter of the distinguished scholars of the time. This prince was himself a learned man, and manifested his love of learning by the patronage of learned authors. ${ }^{1}$

It is stated in Hadiqatul-Aqãlim (MS. in ASB, leaf 69) that the Sulțān once sent a man to Gujrāt to inspect its splendid buildings. When the person reported that with all his wealth, the Sultān could not erect similar buildings in Multān, he was much disappointed. But the Wazir to console him said that though Gujrāt was noted for its buildings, Multān was superior to it in learning.

9. Sindh, Kashmīr and GujRĀt.

Of the royal house of Sindh, Shāh Beg Arghūn was exceedingly well read, and is men- Third detioned by many authors as a great promoter $\begin{gathered}\text { cade of the } \\ \mathbf{1} \text { th century. }\end{gathered}$ of literature, ${ }^{2}$ while Kashmīr could about 50 years ago boast of its ruler Zainul 'Ābidin, who had equally encouraged literature and fine arts. Under the latter many treatises on music were written, and a

1 Ferishta vol. iv, p. 385 .

${ }^{2}$ Ibid., p. 432. 
code of laws was framed, engraved on copper-plates, and placed in public markets and halls of justice in order to give it currency. ${ }^{1}$

We learn that during Akbar's reign, Husain Khān, Walī of Kashminr, built madrasahs there, and gave as endowment pergana Āsāpūr (974 A.H., I 567 A.D.). ${ }^{2}$

Muzaffar Shāh II was a royal Maecenas of Gujrāt. He promoted learning with great zeal, and men of letters from Persia, Arabia and Turkey found it worth while to settle in Gujrāt in his liberal reign. ${ }^{3}$

\section{IO. BENGAI.}

The colleges built by Bakhtiyār Khiljī have been referred to in another connection.

Governor Ghiyāṣuddīn (1212-27 A.D.) built a superb mosque, a college and a caravansarai at Lucknauti soon after his election to the masnad of Bengal. $\mathrm{He}$ was a liberal encourager of arts and literature, and bestowed ample pensions upon the learned. ${ }^{4}$ Rajah Kãnis (1385-92) granted pensions to the learned Muhammadans during the short time that he ruled Bengal. His motive

1 Ferishta vol. iv, pp. 469, 470; Ma'ásiri-Rahīmī, MS. in ASB, leaf 59.

${ }^{2} M a^{\prime} a$ șiri-Rahimiñ, MS. in ASB, leaf 7r. N.K.T., p. 363, mentions Husain Chak giving pergana Zainpūr for madrasah, etc.

${ }^{3}$ Ferishta vol. iv, p. 97.

4 Stewart's History of Bengal, pp. 56, 57. 


\section{THE MINOR MUSLIM KINGDOMS}

for the bestowal of such stipends was not, however, the promotion of learning pure and simple, but was mixed up with an ulterior political purpose. ${ }^{1}$

The efforts of the rulers of Bengal were not confined to the promotion of Muhammadan learning alone, for they also directed their fostering care for the advancement of letters into a new channel, which is of particular interest to the Bengali-speaking people. It may seem to them an anomaly that their language should owe its elevation to a literary status not to themselves but to the Muhammadans, whose interest in it was at first evoked by merely a sense of the curious, and was indirectly roused by its connection with Sanskrit, which formed a most cherished treasure of the vast Hindu population with whom they had to come into frequent contact. It was the epics-the Ramäyãna and the Mahäbhärata-that first attracted the notice of the Muhammadan rulers of Bengal, at whose instance they were translated into Bengali-the language of their domicile. The first Bengali rendering of the Mahābārata was ordered by Nāșir Shāh of Bengal (I 282-I325 A.D.), who was a great patron of the vernacular of the province, and whom the great poet Vidyāpati has immortalized by dedicating to him one of his songs. Vidyāpati also makes a respectful reference to Sulțān Ghiyāșuddīn, most probably Sulțān Ghiyāṣuddīn II 
of Bengal (1367-73 A.D.). [See Stewart's list of independent Kings of Bengal.]

Moreover, we learn from the Riyäzul-Salätin that this Sulțān was himself a poet, and once composed a verse which no one in his Court could make into a couplet. It was then sent to the famous poet Hāfiz, at Shīrāz, who, at the very sight of it, supplied the complementary verse. ${ }^{1}$ Sulțān Ghiyāsuddin's tutor of theology was Hamiduddin of Nagore. The only fellow-student with whom he studied was the saint Qutbul 'A lam. ${ }^{2}$ It is doubtful whether a Muslim ruler of Bengal or the Hindu Rājā Kansa Nārãyaṇa appointed Kīrttivāsa to translate the Ramäyana into Bengali; even if the latter story be true, it is undoubted that Muslim precedents influenced the action of the Rājā. ${ }^{3}$

Near the village of 'Umārpür there is a spot called Darasbäri, or the College. A very large inscription of the time of Yüsuf Shăh (dated 1479 A.D.), found at the place, refers to the building of a Masjid. "It is, however, very probable that the Masjid may have been attached to the college, as the stone is much too heavy to have been moved from its original site." ${ }^{4}$ Many a madrasah like

1 English translation of Riyāzul-Salāțin by 'Abdul Salām (Bibl. Indica), p. 109 ; Stewart's History of Bengal, pp. 92, 93.

2 Stewart's History of Bengal, p. I I I.

3 For the above information (p. 107 also), see Mr. Dinesh Chandra Sen's History of Bengali Literature (I91 I), pp. 10-12, I40, and 222.

4 Archaeological Survey Report, vol. xv, p. 76. 


\section{THE MINOR MUSLIM KINGDOMS}

the present one is fast losing all its marks by which it can be identified as such. The madrasah, for instance, which was built by the Musalmãns at Asthipura (Place of Bones), where, it is said, the bodies of all the slain in the eighteen days' battle between the Kauravas and the Panduavas were collected and burnt, has already disappeared, leaving but a mound which can be recognized as the remnant of a college only by its name of MadrasahTilā. $^{1}$

Emperor Husain Shāh was a great patron of Bengali. Mālādhar Basu was appointed by him to translate the Bhägavata Purāna into Bengali. ${ }^{2}$ We also learn that he founded a college as a memorial to the famous saint Qutbul 'Ālam, as will be found from the following extract:-

"Amongst the numerous instances of his piety, he settled a grant of lands for the support of the tomb, college and hospital of the celebrated saint Qutbul 'A lam, which are continued to this day, and every year made a pilgrimage on foot from Akḍālā to Pānduyà to visit the holy shrine of the saint." 3

There were ruins of a quadrangular building on the north bank of the Sägar Dīghi (a reservoir) in Gour, which are said to have been a madrasah probably built by Husain Shāh. From the ruins it

1 Archaeological Survey Report, vol. xiv, p. 98.

2 Mr. Dinesh Chandra Sen's Hist. of Bengali Litr. (I9I I), pp. I4-1 2 and 222.

3 Stewart's History of Bengal, p. I 3. 


\section{PROMOTION OF LEARNING}

can be seen that the madrasah was of elegant shape and considerable size, and built of marble and granite different in character from those found in any other part of Gour. ${ }^{1}$

In his Khurshìd-fahān-Numāh, Ilāhī Bakhshal-Ḥusainī mentions a madrasah in Ghūrāshāāid, a quarter in Gour, in the neighbourhood of the residence of Ghulām Husain, the well-known author of the Riyāzul-Salätin. ${ }^{2}$ An inscription ascribed to the madrasah mentions the founder as Husain Shäh. ${ }^{3}$

Parāgal Khān, a general of Husain Shāh, and Parāgal's son Chhuṭi Khān, have made themselves immortal by associating their names with the Bengali translation of a portion of the Mahäbhärata. ${ }^{4}$

Parāgal Khān used to invite his courtiers every evening to his palace at Parāgalpūr in Feni, to hear

1 Ravenshaw's Gour, p. 34; and Blochmann's contribution to F.A.S.B., vol. xliii, pt. I, p. 303.

${ }^{2}$ Khurshīd-Fahān-Numāh, by Sayyid Ilāhī Bakhshh-al-Husainī Āngrezābādī, MS. in ASB, pp. I30, 131. This madrasah is also mentioned in Khurshìd-Fahān-Numāh (translation of its fragments in F.A.S.B., 1895, p. 198).

3 The inscription is as follows :- " The Prophet (God's blessings on him) has said, 'Search after knowledge and if it were in China.' This excellent Madrasah was ordered to be built by the great and generous King, the Sayyid of the Sayyids, the source of auspiciousness. . . . 'Alā'uddunyā Wauddīn Abul Muzaffar Husain Shāh the King, the Husaini-may God perpetuate his kingdom, for the teaching of the sciences of religion and instruction in those orders which alone are true ... On the Ist Ramazān, 907 A.H. (10th March, I 502 A.D.)."-Ravenshaw's Gour, p. 80.

4 Mr. Dinesh Chandra Sen's Hist. of Bengali Litr., p. 12. 


\section{THE MINOR MUSLIM KINGDOMS}

the recitation of the Bengali Mahäbhärata by the translator Kavindra Paramesंvara. Under Parāgal, the epic was translated up to the Stri Parva, but Chhuți Khān, who succeeded Parāgal in the governorship of Chittagong, followed up the work by appointing a poet named Srikarana Nandi, whom he ordered to translate the Asvamedha Parva.

Examples of Bengali translation of Sanskrit and Persian books at the instance of Musalmān chiefs are not rare. They served to remove the supercilious spirit in which Bengali was looked upon by the Sanskrit-loving Brāhmanas and the Hindu Rājās. The latter imitated the Muhammadan rulers and chiefs in giving their patronage to Bengali writers, and the institution of keeping "Bengali court-poets" grew into a fashion. Many distinguished Bengali poets and writers have since adorned the Courts of Hindu Rājās, which raised Bengali to a high place in the estimation of the people and made it a rival of the languages that had already established their footing, ${ }^{1}$

Nawāb Murshid Qulī Ja'far Khān (I704-25 A.D.) "possessed very extensive learning and paid great respect to men who were eminent for their piety or erudition : he wrote with great elegance, and was a remarkably fine penman." ${ }^{2}$ Every morning

1 Mr. Dinesh Chandra Sen's Hist. of Bengali Litr., p. I4.

2 Stewart's History of Bengal, p. 408. 


\section{PROMOTION OF LEARNING}

he spent some time in copying the Qur'ān, so that every year he sent Qur'ans of his own writing with valuable offerings to Mecca, Medina and other holy places. "He maintained above two thousand readers, bards and chanters, who were constantly employed in reading the Qur'an and in other acts of devotion." 1

About this time there was a very liberal Zemindar at Birbhum named Asadullāh. He dedicated half of his income to the support of the learned and other charitable purposes. ${ }^{2}$

The Siyarul-Mutaakhkhirin says that 'Alīwardi Khān was a lover of learning, and on quitting 'Āzimābād, invited to his Court men of learning, whom he requested to live in Murshidābād his capital, and for whom he fixed large stipends. One of them was Mìr Muhammad 'Alī, another was Husain Khān. Tākī Qulī Khān, 'Alī Ibrāhīm Kh hān, Hājī Muḥammad Khān, were also of the number. ${ }^{3}$ Mìr Muhammad 'Alī possessed a library of two thousand volumes. ${ }^{4}$

Mīr Qāsim, it appears, encouraged a few learned

1 Stewart's History of Bengal, p. 406 ; vide also 'Abdul Salām's Riyāzul-Salātīn, p. 279.

2 Stewart's History of Bengal, p. 37 I ; 'Abdul Salām's RiyāzulSalātīn, p. 257.

3 'Siyarul-Mutaakhkhirinn, by Sayyid Ghulām Husain Khān (English transl.), vol. ii, pp. 69, 70 and $165 \mathrm{ff}$.

4 Ibid., p. 63 n. 


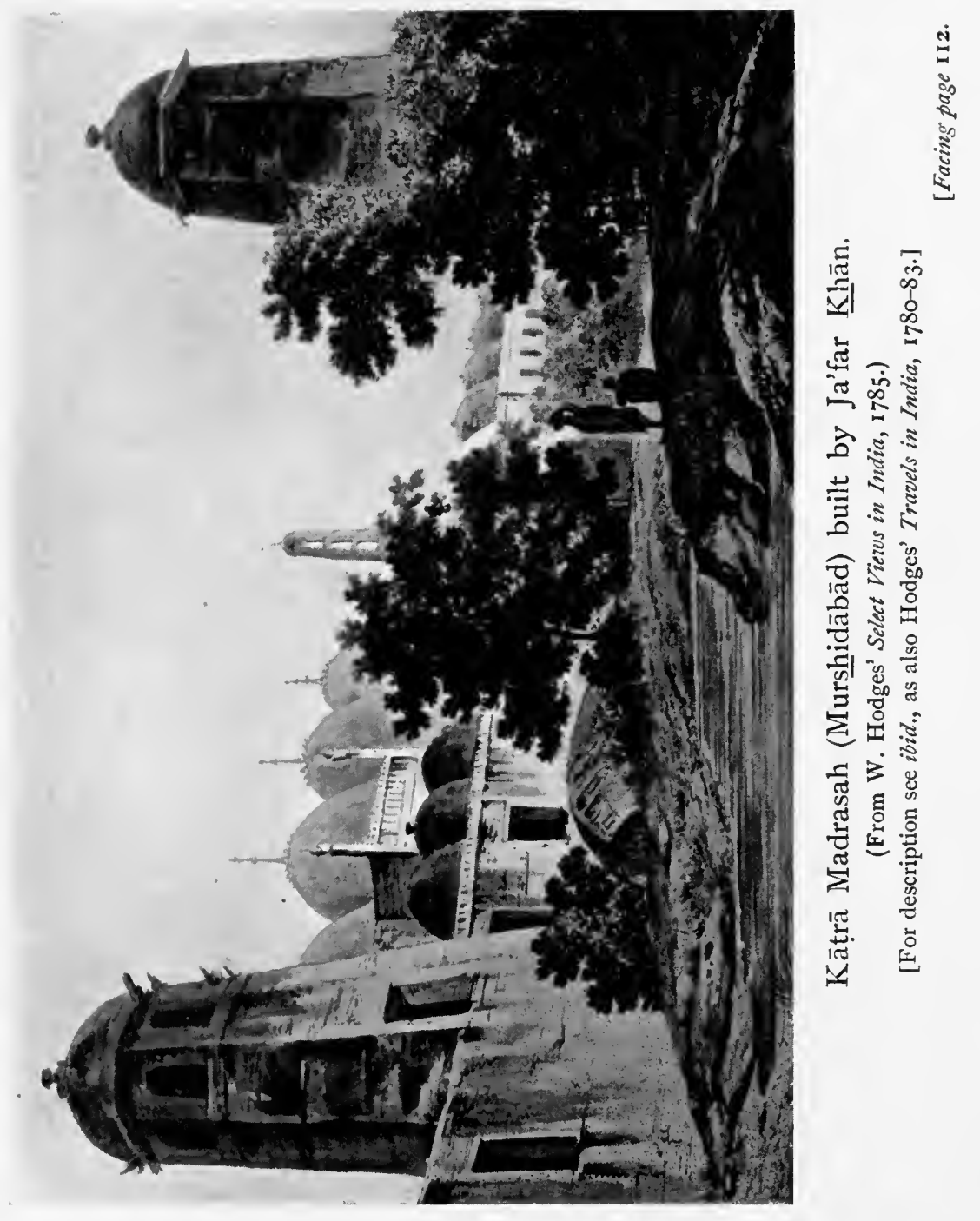


$\because: \therefore$

$\therefore: y^{2}$ 


\section{THE MINOR MUSLIM KINGDOMS}

men, and some instances of his patronage are recorded in the Siyar. ${ }^{1}$

Towards the end of the eighteenth century, there were some small educational institutions at Silāpūr in Bengal. Here both Hindus and Muhammadans were taught Persian and Arabic. ${ }^{2}$

1 Siyarul-Mutaakhkhirīn, by Sayyid Ghulām Husain Khān (English transl.), vol. ii, pp. 432-434.

${ }^{2}$ Khurshīi-Fahān-Numäh, MS. in ASB, p. 169.

[Note.-Regarding Chahār Minār at p. 95, this chapter, we learn from Major T. W. Haig's Historical Landmarks of the Deccan, p. 210, that it is represented on the obverse of the modern Haidarābād rupee.] 
RETROSPECT.

WE have now surveyed the progress of education under the Pathān rulers of India. It is now clear that their contributions to that cause should be sufficient to weaken the popular opinion which associates the Pațhān Dynasty exclusively with battle and bloodshed through which it rose to power, and not with any of the triumphs of peace by which the newly-conquered territories were being consolidated. The Paṭhān Dynasty, as we have seen, can count among its members a few rulers who have contributed a good deal towards this work of consolidation,- - towards the diffusion of education in the country. In the forefront of this band of workers, stands the great Fìrūz Tughlaq, whose educational zeal and enterprise constitute a record, of which the best monarch of any nation in the world might justly be proud. The reign of 'Alāuddin again marks a period of literary and educational efflorescence which bespeaks the activities of the preceding rulers strengthened by those of the people-the chiefs, the nobility and the gentry. The encouragement of 


\section{THE PRE-MUGHAL PERIOD}

literary men and literature, which gives a strong stimulus to literary and educational progress, was with a few Paṭhān rulers, and princes an important item of their life's programme. The most prominent of those were Balban and his worthy son Muḥammad, Nașīruddīn, and Muḥammad Tughlaq. While summing up the educational works of the Paṭhān Dynasty, we should not omit to take note of the educational work done by some of the small independent kingdoms. The name of Fìrūz Bahmanī, whose encouragement of literary men and education has secured for him a high place among the benefactors of Musalmān education, was a name to conjure with in the literary world of his day, and his practice of sending ships annually to different countries in search of learned men was an institution that stands out as quite a unique feature of his reign. The Bahmani Dynasty, indeed, did not possess a second such ruler but could boast of a few others who also distinguished themselves by their services to the cause of learning. The dynasty of Gulkandah has been glorified by King Quțb Shāh, who gave a great impetus to education by the foundation of colleges and public seminaries, and by his patronage of learned men. The other principalities such as Khāndish also blessed with their own royal Maecenases who have left behind a good record of their educational and literary enterprise. 


\section{PROMOTION OF LEARNING}

While recounting the achievements of these rulers, we should also remember that private enterprise was also active in the cause of education. There were gentlemen in whom "power" and "goodness" were combined in equal proportions. Maḥmūd Gāwān, the nobleman of Bìdar, was liberal to prodigality, and the best of the colleges founded by him still stands in a mutilated state to testify to the beneficence of the donor. The generosity of some nobles in the reigns of 'Alāuddin and Sikandar has already been mentioned. Indeed, the cause of education had its friends among the nobility and the gentry, whose patronage was a potent factor in its furtherance.

We have also seen how Delhi rose to its high position as a seat of learning through so many vicissitudes of fortune, and became both the intellectual and political capital of Muhammadan India. We have also noticed how Fīrūzābād eclipsed Delhi, and after a time was itself eclipsed by other literary centres, and how there were multiplied other centres of learning in the country, such as those at Agra, Jaunpūr, Bīdar, Haidarābād, Badā'ūn, etc.

Some of these centres of Muhammadan learning, as we learn from the accounts given of them, were in no way inferior to Samarqand or Bukhārā, Baghdād, Cairo or Damascus. The influx of learned men from countries outside India shows the 


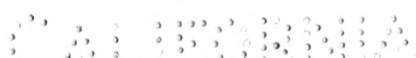




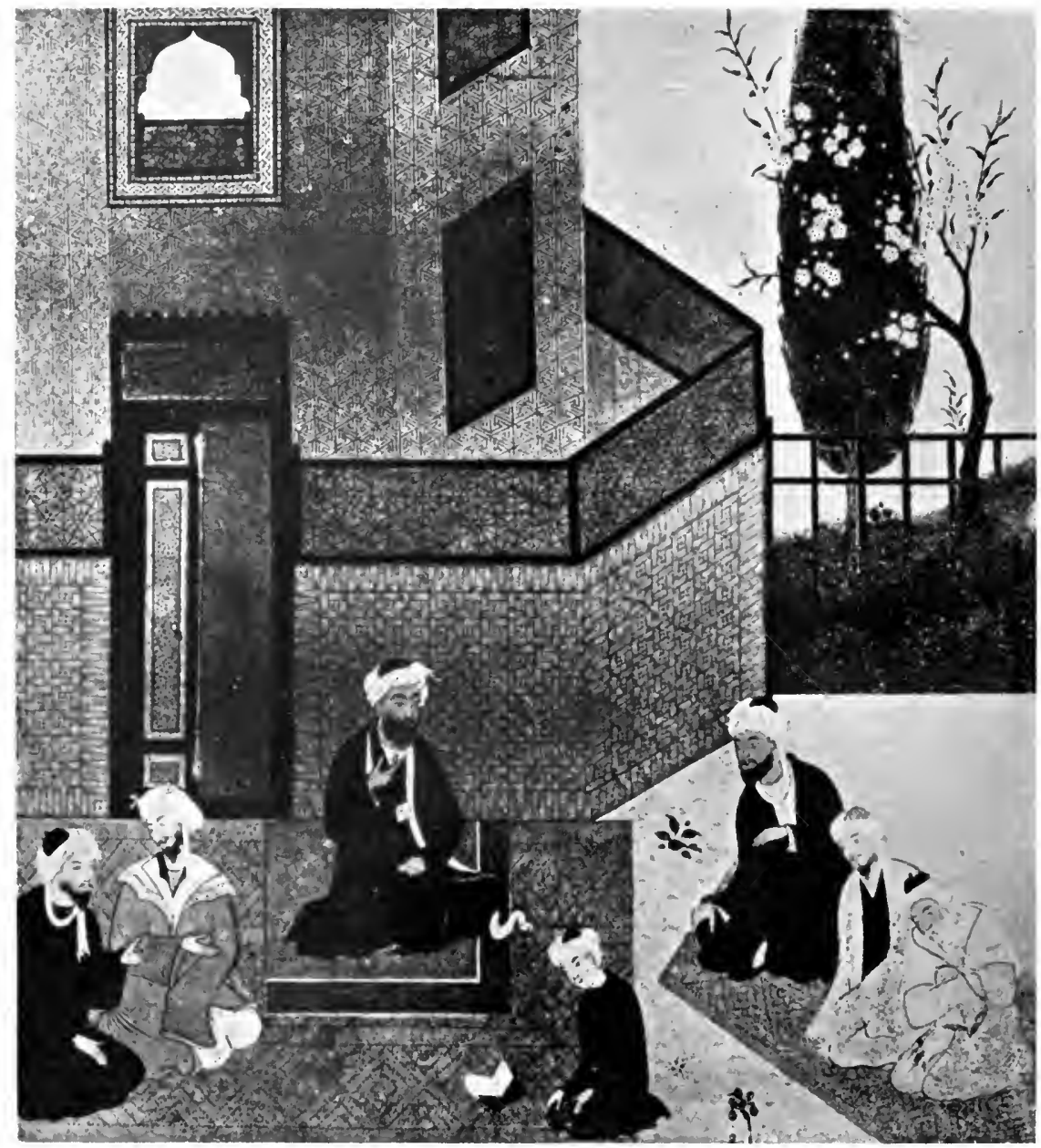

Domestic System of Teaching among the Muhammadans. A Teacher with his Pupils. By Bihzād, the famous Persian Painter. [Preserved in the Imperial Library, St. Petersburg (Petrograd).]

[From Martin's Miniature Painting and Painters of Persia, India and Turkey (Bernard Quaritch).] 


\section{THE PRE-MUGHAL PERIOD}

superior literary life which India afforded them in those days.

While speaking of the schools and colleges as centres of instruction, we should not allow our attention to be engrossed by them and them alone. We should take note of the unobtrusive but useful educational works done by the unconventional domestic system of teaching. It made the house of a learned man a centre of instruction, which sometimes supplied the students with both board and lodging. Thus to quote a single instance, we find the author of the Tärikh-Tähiri studying in the house of his preceptor Maulānā Isḥāq, and perusing Sa'dī, Jāmī, Khāqānī and Anwarī. ${ }^{1}$ Such educational centres, small but numerous, not only provided a field for post-collegiate studies, but were also in many cases the only means by which instruction in some subjects was imparted. The schools and colleges did not generally provide for such a training; it was for this reason that we find a learner of music or painting, for instance, taking his lessons from his chosen ustäd in the latter's house. The technical education was diffused by the system of apprenticeship. We notice, in the provision made by Fìrūz Tughlaq for the technical education of the slaves he brought up, that they were placed under master-craftsmen in their shops or manufactories, to learn the different arts. 
3

$\because$ 


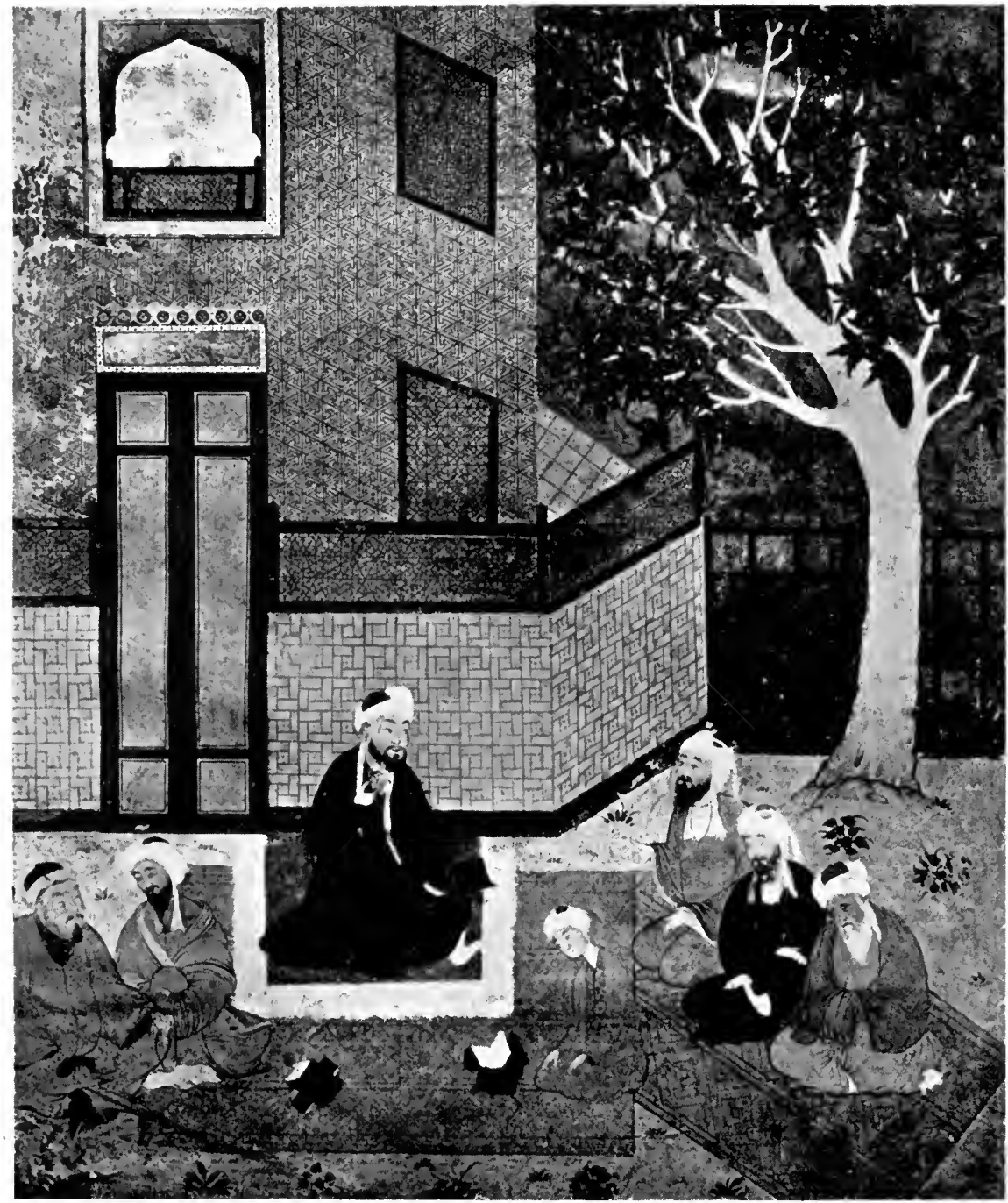

A Teacher with his Pupils. By Bihzād.

[From Martin's Miniature Painting and Painters of Persia, India and Turkey (Bernard Quaritch).]

[Facing page I18. 


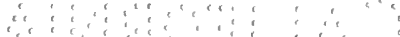

$\therefore$

$\because$ 


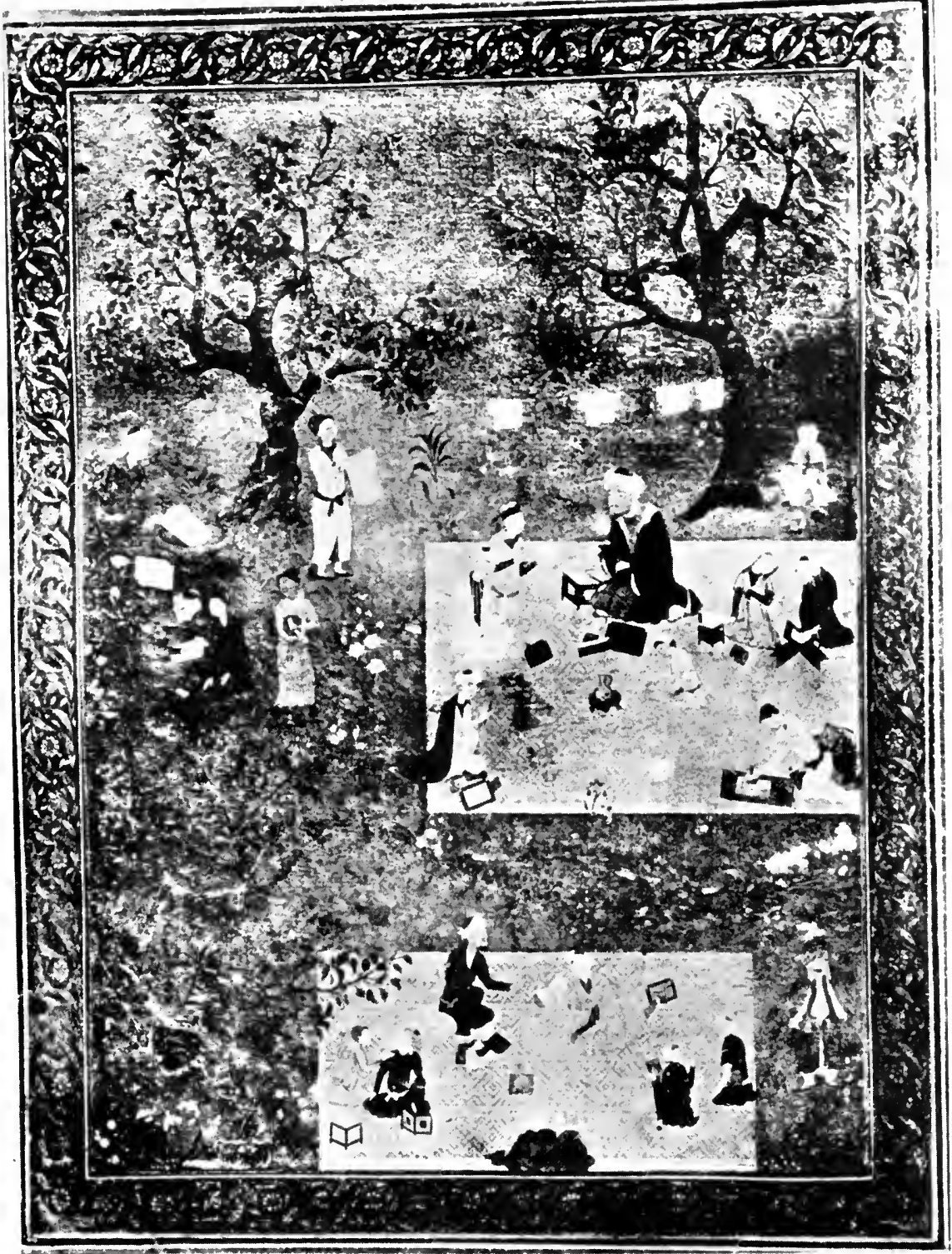

Teachers and their Pupils. By Bihzăd.

[Preserved in the Imperial Library, St. Petersburg (Petrograd).]

[From Martin's Miniature Painting ant Puinters of Persia, India and Turkey (Bernard Quaritch).] 
$\because \vdots \quad \because \cdots \cdots$

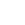




\section{BOOK II. \\ THE MUGHAL PERIOD.}




\section{,}




\title{
CHAPTER I. \\ The Mughal Dynasty.
}

\author{
I. BĀBAR.
}

BÄBAR had some of the sturdier qualities that characterized his ancestor Tìmür; but he was more refined and accomplished than that monarch. The high encomiums showered by Mr. Erskine on this Sultān have not been misplaced :-

"Upon the whole, if we review with impartiality the history of Asia, we shall find few princes who are entitled to rank higher than Bābar in genius and accomplishments. His grandson Akbar may perhaps be placed above him for profound and benevolent policy. The crooked artifice of Aurangzib is not entitled to the same distinction. The merit of Changiz Khān and Tamerlaine (Tìmür-i-Lang) terminated in their splendid conquests, which far excelled the achievements of Bābar, but in activity of mind, in his gay equanimity and in the possession of manly and social virtues, we shall probably find no other Asiatic prince who can justly be placed beside him." 1

To these qualities should, however, be added his literary accomplishments. He was a great scholar in Arabic, Persian and Turkì, and a fastidious critic. ${ }^{2}$ He cultivated the art of poetry from his early years and is mentioned as the author

1 Erskine's Memoirs of Bäbar, p. 432.

2 Tüzaki-Bābari, Elliot iv, p. 219. 
of a collection of Turki poems, many of which are quoted in his Memoirs. Abul Fazl speaks of a Persian Mașnawi of his composition, which had a large circulation. He was also the author of a work on prosody and a few other smaller books. But the greatest of all his works is his Memoirs, ${ }^{1}$ written in the Turkish language. ${ }^{2} \mathrm{He}$ also transposed into poetry the work of Khwājah Ahrār. He was an adept both in prose and verse, and his skill in music on which he wrote a treatise was also of a high order. ${ }^{3}$ Mìrzā Muhammad Haidar, the author of the Tärikhi-Rashidi, says-

"In the composition of Turki poetry he was second only to Amìr 'Alī Shìr. . . . He invented a style of verse called Mubaiyan, and was the author of a most useful treatise on Jurisprudence, which has been adopted generally. $\mathrm{He}$ also wrote a tract on Turkish prosody, superior in elegance to any other, and put into verse the Risallah-i-Walidiyah of his Holiness." "4

We also learn from the Tärikhi-Muzaffari that he versified a small religious tract written in honour of 'Ubaidullāh's parents. He also composed a book on prosody, entitled Mufașal.

1 Bābar's Memoirs was translated into Persian by Khān Khānān at the instance of Akbar; vide Mir'atul-'Alam MS. in the Boh. Coll., leaf 179 .

2 Erskine's Memoirs of Bābar, p. 43I; also Ferishta vol. ii, pp. 61 and 65.

3 Ibid.

4 Translation by E. D. Ross and N. Elias, pp. 173, 174. See also Muntakhabul-Tawārikhh, vol. i, (Ranking), p. 449.

5 Tärīhhi-Muzaffarī, by Muhammad 'Alī Khāan Anșārī, MS. in ASB, pp. I4, I 5 . 


\section{THE MUGHAL DYNASTY}

In 1504 A.D., he initiated a kind of handwriting called the Bābari hand. ${ }^{1}$ He indited a copy of the Qur'an in that script and sent it to Mecca. ${ }^{2}$

Regarding Bābar's education, Mr. Lanepoole says-

"At the age of five the child (Bābar) was taken on a visit to Samarqand. . . . The next six years must have been spent in education and well spent, for he had little leisure (later on) to improve himself, and his remarkable attainments in the two languages he wrote imply steady application. Of his early training we hear nothing, but it is reasonable to suppose that an important part of it was due to the women of his family." 3

A jovial man as he was, he used to hold frequent parties, in which extempore verses and recitations in Turkish and Persian often came as a ballast to the coarseness that at times tainted them. However, many literary men were his companions, and his Memoirs describes a party of literary men on a boat in which they and Bābar amused themselves by making verses. ${ }^{4}$

Some of the literary men who came into contact with Bābar and received reward and encouragement were Khundamir, grandson of the illustrious Mirkhund and the author of the Habibul-Siyar, Maulānā Shahābuddīn the enigmatist, and Mīrzā Ibrāhīm of Hirāt. They were directed by the

1 Talbot's Memoirs of Bābar, p. 97.

2 Muntakhabul-Tawärikh, vol. i, (Ranking), p. 449.

${ }^{3}$ Lanepoole's Bābar, p. 22 ; p. 30 mentions "Sk. Mazīd" as Bābar's tutor.

${ }^{4}$ Erskine's Memoirs of Bābar, p. $29 \mathrm{I}$. 
Sulțān to live at his court. Khundamir had to leave Hirāt owing to troubles raging there, and came to Hindustan, where he was introduced to Emperor Bābar at Agra. He accompanied the Emperor to Bengal in his expedition, and upon his death was favoured by Humāyūn, in whose name he wrote the Qanuini-Humàyun, quoted by Abul Fazl in the Akbar-Nāmah. He accompanied Humāyūn to Gujrāt, where he died (I534-35 A.D.), and his body was buried in Delhi by the side of Nizāmuddin Auliyā and Amīr Khusrau. ${ }^{1}$

In his early career as an author, he had been much helped by the learned minister of Sulțān Husain of Hirāt, who collected a valuable library of the most esteemed works of the time, and placed him in charge of it. $^{2}$

However great might be the reputation of Bābar's Memoirs for accuracy of statement, it certainly fails in this respect, when it says that Hindustan had no college in it. The passage runs thus: "The people of Hindustan have no good horses, no good flesh, no grapes or musk-melons, no good fruits, no ice or cold water, no good food or bread in their bāzārs, no baths or colleges, no candles, no torches, not a candle-stick." The statement will, of course, be taken for what it is worth. ${ }^{3}$

1 Elliot iv, pp. 14I, 143.

I Ibid.

3 Bäbar's Memoirs, p. 333 (or Talbot's Memoirs of Bābar, p. 190). 


\section{THE MUGHAL DYNASTY}

Regarding the Hindu astronomical science as cultivated in India, and the calculations made under it, Bābar makes the following remarks in his Memoirs in connection with the observatory which existed at that time in Samarqand, the calculations of which were followed by the Muhammadans in India.

"By means of this observatory, Ulugh Beg Mirzā composed the Kürkānī Astronomical Tables, which are followed at the present time, scarcely any other being used. Before they were published, the İlkhāni Astronomical Tables were in general use, constructed by Khwājah Nașr in the time of Halākū, in an observatory built at Marāghha. Halākū Khān was also denominated Īlkhānī. Not more than seven or eight observatories have been constructed in the world. Among these, one was erected by Khalif Māmūn, in which the Astronomical Tables entitled ' $Z \bar{i} c h$ Māmūnī' were drawn up. Another was built by Baṭlmīus (Ptolemy). Another was the observatory erected in Hindustan in the time of Rājah Vikramājit, a Hindu, in Ujjain and Dhar in the kingdom of Mālwa, now known as the kingdom of Mandu. The Hindus still follow the Tables that were then constructed. These Tables are, however, more imperfect than any of the others. Since the building of that observatory till the present time is 1584 years." ${ }^{1}$

Ghāzì Khān, the Afghān noble of the Punjāb, who invited Bābar to deliver the Afghāns from the Emperor Ibrāhim, had a good library, containing a number of valuable books. Bābar imprisoned him for treachery, and after his escape, examined the library in I525 A.D., and sent some of its books to

${ }^{1}$ Erskine's Memoirs of Bābar, pp. 50, 51. The task of framing the Tables was given by Ulugh Beg Mìrzā first to Qāzịzāāah Rūmĩ, and on his death to Maulānā Ghiyāsuddīn Jamshịid, and then to Ibn 'Alì Muhammad Koshjī. 


\section{PROMOTION OF LEARNING}

Humāyūn and Kāmrān for their use. The library had in it a few theological books which also attracted the notice of the Sultān. However, Bābar was not satisfied with the collection, for says he: "I did not on the whole find so many books of value as, from their appearance, I had expected." 1

The practice of making a book more lucid and interesting by the insertion of illustrations in it, is at least as old in Muhammadan India as the time of Bābar. His Memoirs was embellished with coloured representations of animals described therein, which formed an attractive feature of the book. Jahāngìr, however, finds fault with them, for most probably the painters did not draw them from life. This defect he avoided in his own Jahängir Nämah. ${ }^{2}$

Bābar was interested in painting and took with him to India all the specimens he could collect from the library of his ancestors (the Timurides), some of which were taken back to Persia by Nādir Shāh after the conquest of Delhi. These manuscripts exercised the greatest influence on the art of India. ${ }^{3}$

We learn from the Tawairikh of Sayyid Maqbar 'Alī, a minister of Bābar, that the Public Works

1 Talbot's Memoirs of Bäbar, p. 176; also Tazkiratul-Salātīn, MS. in Boh. Coll., leaf ro4.

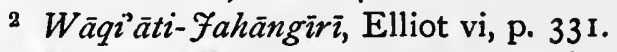

3 Martin's Miniature Painting and Painters of India, Persia and Turkey, vol. i, p. 79. 


\section{THE MUGHAL DYNASTY}

Department (Shuhrati 'Ām) of the time, which continued through the reigns of the succeeding Mughal emperors, was entrusted, among other duties, with that of conducting postal service, the publication of a Gazette, and the building of schools and colleges. That the educational works received attention of Government, appears from their being made into an item of duty of a state department.'

Of the learned men of Bābar's time may be mentioned Shaikh Zain Khwāfi, who translated the Wāqiāti-Bābarì, Maulānā Baqā'ì and Maulānā Shahābuddīn, the enigmatist. ${ }^{2}$

\section{HUMĀYŪN.}

Humāyūn followed up the traditions of his father and used to spend his time in social intercourse and amusements, in State duties and studies. He loved to study astronomy and geography, and wrote dissertations on the nature of the elements. For his own use, he caused to be constructed both terrestrial and celestial globes. ${ }^{3} \mathrm{He}$ was fond of

i G. Sāstrì's article in the Navya Bharata, I 305 B.S., p. 7 I.

2 Muntakhabul-Tawärikh, vol. i, (Ranking), p. 449; A.N., I., pp. $280 \mathrm{ff}$,

3 Ferishta vol. ii, pp. 70, $7 \mathbf{1}$; Tärikhhi-Akbarï, MS. in ASB, leaf 19; Tārikhi-Salätīni-Afäghinah, $\overline{\mathrm{MS}}$. in ASB, by Ahmad Yādgār, leaf $20 \overline{8}$; Abul Faẓl, in his $A k b a r-N a \overline{m a h}$, vol. i, p. 287 (Beveridge), says: "His noble nature was marked by the combination of the energy of Alexander and the learning of Aristotle." 


\section{PROMOTION OF LEARNING}

the company of learned men, poets and philosophers, and used to discuss literary subjects with them. He was fond of poetry, and himself composed good verses. $^{1}$

When Humāyūn was four years, four months and four days old, a ceremony was gone through for celebrating the occasion of his being first put under tutors. The child Sultān was seated in the school-house and formally made over to the care of the tutors. ${ }^{2}$ Shäh-Jahãn-Nämah calls it "maktab ceremony." ${ }^{3}$

Mr. L. F. Smith saw this ceremony in I80 I among the Muhammadans in N.W.P., and in a letter, gives the following details of the same:"When the boy is four years, four months, four days old, for him a silver slate is made, and they write on it the Sürahi-Iqra', a chapter of the Qur'an, and make him repeat it; at this time, a master is kept for him." 4

This Sulțān was fond of magnificence in his court, and made classifications of the inhabitants of his empire, created gradations of rank, built several halls for the receptions of the separate classes, and had fixed days for giving them

1 Muntakhabul-Tawärikh, vol. i, (Ranking), p. 602; Ferishta vol. ii, pp. 178-180.

2 Tazkiratul-Salätīn, MS. in Boh. Coll., vol. i, leaf 169.

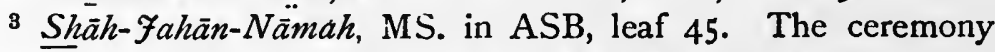
looks very much like the Hâte Khadı ( शाতত থড়ি) of the Hindus.

${ }^{4}$ L. F. Smith's A ppendix to Chahār Darwish p. 253. 


\section{THE MUGHAL DYNASTY}

audience. In this arrangement it is interesting to notice how the literary men were treated, and what place was assigned to them.

The people of his empire were divided into three classes :-

(i) The holy men, the literati, the law-officers and scientists formed a class called Ahli-Sa'ādat, because to associate with such men, to honour and regard them would bring eternal prosperity.

(ii) The relations of the Sultān, the nobles and ministers as well as the military, formed the group called Ahli-Daulat, for no wealth could be attained without them.

(iii) Those who possessed beauty and elegance, were young and lovely, as also the musicians and singers, formed another class to which the appellation of Ahli-Murād (people of pleasure) was given. ${ }^{1}$

The king also divided the days of the week and appointed two days for each of these three classes. Saturdays and Thursdays were allotted to class (i), the reason being that Saturday is ascribed to Saturn, and Thursday to Jupiter-the planets that protect and preserve the men comprised in the class. Sundays and Tuesdays were fixed for class (ii), for Sunday belongs to the Sun, to which is attached the fate of all rulers, and

1 Humāyūın-Nāmah, Elliot v, pp. I I9, 120. 
Tuesday to Mars, the patron of warriors and brave men. Mondays and Wednesdays were set apart for class (iii), because Monday is the day of the Moon and Wednesday of Mercury, and it was thought reasonable that the king should keep company on those days with "young men beautiful as the moon, and hear sweet songs and delightful music."

On Fridays, as the name (Jamu'ah) signifies, he called together all the three classes, and sat with them as long as his leisure allowed. ${ }^{1}$

The above three classes do not show the place that men of letters occupied in his estimation, but the subdivisions that he introduced leave no doubt on the point. He distributed arrows of gold with different proportions of alloy to indicate the ranks of their possessors. The three classes were divided into twelve sub-classes of Arrows. The twelfth arrow, which was made of the purest gold, was put in the quiver of the king himself, giving him the highest rank. The eleventh arrow belonged to $\mathrm{His}$ Majesty's relations and all the "Sultans" in the government employ. The tenth to the learned and religious, the ninth to the great nobles, the eighth to the courtiers and some of the king's personal attendants, the seventh to the attendants in general, the sixth to the harems and well-behaved female

1 Humäyūn-Nāmah, Elliot v, pp. I21, 122. 


\section{THE MUGHAL DYNASTY}

attendants, the fifth to young maid-servants, the fourth to the treasurers and stewards, the third to the soldiers, the second to the menial servants, and the first to the palace-guards, camel-drivers and the like.

Each of these arrows or orders had, moreover, three grades, the highest, the middle and the lowest. ${ }^{1}$

Ferishta records that the Sulțān built seven halls of audience, in which he received distinct classes of persons. The seven halls were respectively named after the seven planets. In the Palace of the Moon he gave audience to travellers, ambassadors, etc. The Palace of 'Utārid or Mercury was for civil officers, and so on. The learned men were received in the Saturn and Jupiter halls. He gave public audience according to the planet of the day, and the furniture and paintings, as also the dresses of the attendants, bore symbols emblematic of the planet. In each of these palaces he transacted business one day in the week by rotation. ${ }^{2}$

Mir 'Abdul Latif, the author of the LubbulTawārikh, was invited by the Sulțān, but he

$1 H u m a \bar{y} u \bar{u} n-N a \bar{m}$ ah, Elliot v, p. I23.

${ }^{2}$ Ferishta vol. ii, p. 7 I. Briggs' note: "Among the Hindus, cities are usually subdivided into puras (wards) called after each day of the week, by which markets are regulated and equally distributed throughout the town; palaces sometimes derive their names from these wards." N.K.T. does not mention seven halls, but seven receptions. 


\section{PROMOTION OF LEARNING}

reached the royal court after Humāyun's death. As he was a great philosopher, theologian and historian, he was appointed a preceptor to Akbar in the second year of his reign. ${ }^{1}$

The distinguished Persian historian, Khundamir, who died in the Emperor's camp in Gujrāt, was one of his literary associates.

Jauhar, the well-known author of the Tazkiratul-Wäqi'ät (Private Memoirs of Humäyün) was a menial servant of the Emperor, in which position he had the opportunity of observing all that he recorded. ${ }^{2}$

Humāyūn was fond of books, and even during expedition carried a select library with him. While fleeing as a fugitive, Count Noer says, he took with him his librarian and a few of his favourite books. ${ }^{3}$ While he was encamped at Cambay he had with him several books, among which was a remarkable copy of the History of Tamerlane, which was taken away by a body of Qulis, a forest tribe, in a night attack upon his camp. This book, however, was subsequently recovered. ${ }^{4}$ Nizāam, father of Lāla Beg, styled Bãz Bahādur, was a librarian to the Sultān. ${ }^{5}$

1 Elliot iv, p. 294.

2 Elliot v, p. I 36.

3 Noer's Akbar, p. 136 (transl. by Annette S. Beveridge).

4 Elphinstone, vol. ii, p. 126 (ed. I84I). Tazkiratul-Salätīn, MS. in Boh. Coll., vol. i., leaf I25, adds that the Timür-Nämah was copied by one Mullā Sultān 'Alī; Akbar-Nämah, vol. i, p. 309 (Beveridge), informs us that it was illustrated by Ustād Bihzād.

5 Tüzaki-Fahāngìrī, by Rogers and Beveridge, p. $2 \mathrm{I}$. 
3
$\vdots$

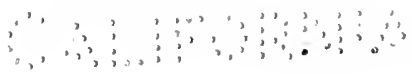




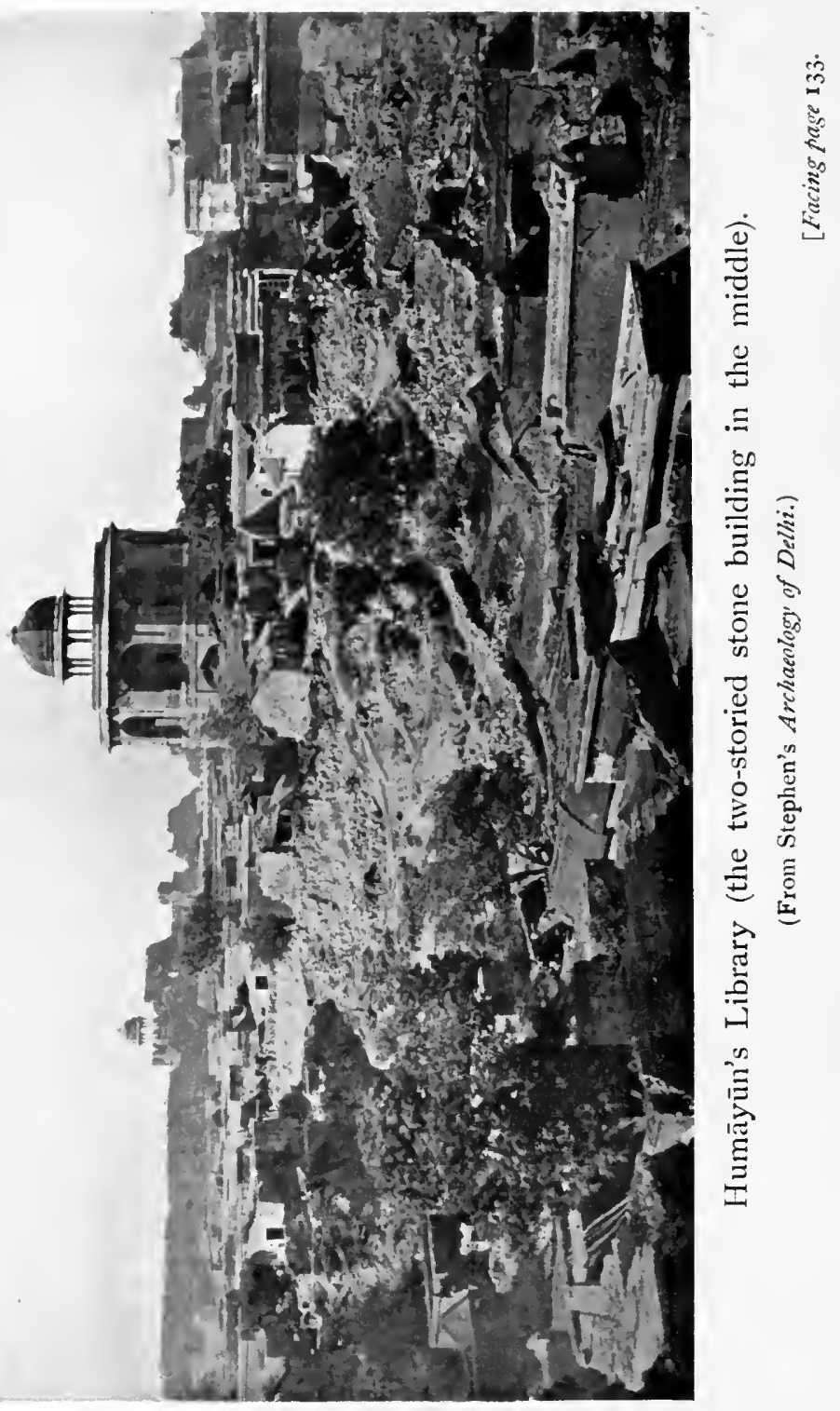




\section{THE MUGHAL DYNASTY}

Humāyūn's literary turn of mind is further manifested by the use he made of the Shir Mandal. It was built by Shīr Shāh in the Purāna Qil'ah, and used as a house of pleasure. But when Humāyūn came to the throne of Delhi the second time, he transformed it into a library. It was here that he met with his death.

"One day," says the author of the Siyarul-Mutaakhkhirin, "there was a conjecture that Venus would rise somewhat later. In the evening, in order that he (Humāyūn) might see that planet, ${ }^{1}$ he went on the top of the roof of his library. There, standing for a moment, he wished to descend. The mi'azzan called to prayers. Humāyūn, in order to show respect to the $a \underline{z} a \bar{a}$, desired to sit down on the second step. The steps of the staircase, by reason of their cleanliness, were very slippery. The ferrule of his staff slipped, and Humāyūn, falling headlong, rolled downstairs on to the ground. ${ }^{2}$ His limbs and joints were much hurt, and the right side of his head received a great blow. He became altogether insensible" ${ }^{3}$ and died some time after (Jan. 1556 A.D.).

We hear of a madrasah built by Humāyūn

1 Sayyid Ahmad (Garcin's Transl., p. 129) confirms the story, but Ferishta differs, and says that the Emperor went there for an airing. See also Ferishta vol. ii, pp. 177, 178. Hearn says, "His death was due to his astrological studies. One evening he was told that Venus ought to be visible, and he determined, if he saw the planet, to promote certain nobles, as it would be fortunate to do so."-Hearn's Seven Cities of Delhi, p. 218.

2 The fact of Humāyūn's "rolling downstairs on to the ground" has been taken as improbable by some writers, e.g. Elphinstone, Marshman, etc., though that is the story told by Ferishta, Muntakhabul-Tawārīkh, Tabaqāti-Akbarī, Mir'ātul-'Alam, Shāh-FahānNämah, etc. That Humāyūn fell headlong over the parapet is taken by them as more likely.

${ }^{3}$ Siyarul-Mutaakhkhirin, as quoted in C. Stephen's Archaeology of Delhi, p. 194. 


\section{PROMOTION OF LEARNING}

yūn.

at Delhi, of which Shaikh Husain was a professor. ${ }^{1}$

Shaikh Zainuddīn Khāfī, who "was unapproachable in his age in the construction of enigmas and chronograms, in extempore versification and in all the minutiae of poetry and prose," died in I534 A.D. near Chinhar (Chunar), and was buried within the precincts of a college founded by him. ${ }^{2} A$ school was built on the side of the Jumna, opposite to Agra, to perpetuate his memory. ${ }^{3}$ These are two examples of educational institutions founded by private individuals during Humāyūn's reign.

It is not generally known that the famous Humāyūn's Tomb, in the vicinity of New Delhi, was at one time used as a place of instruction. That it has not always been a mere tenement beautiful and imposing for sheltering the sarcophagus of the Emperor, and that it housed a madrasah in its bosom, fulfilling a task in addition to the one for which it was built, is testified to by C. Stephen :-

"The college, which is on the roof of the tomb, was at one time an institution of some importance, and men of learning and influence used to be appointed to the charge of the place. It has, however, long ceased to maintain its reputation, and for the last 150

1 Blochmann's $\bar{A}^{\prime}$ ìni-Akbarī, vol. i, p. 538.

2 Muntakhabul-Tawārikh, vol. i, (Ranking), pp. 610, 61 I.

3 Ibid., p. 6ro. 


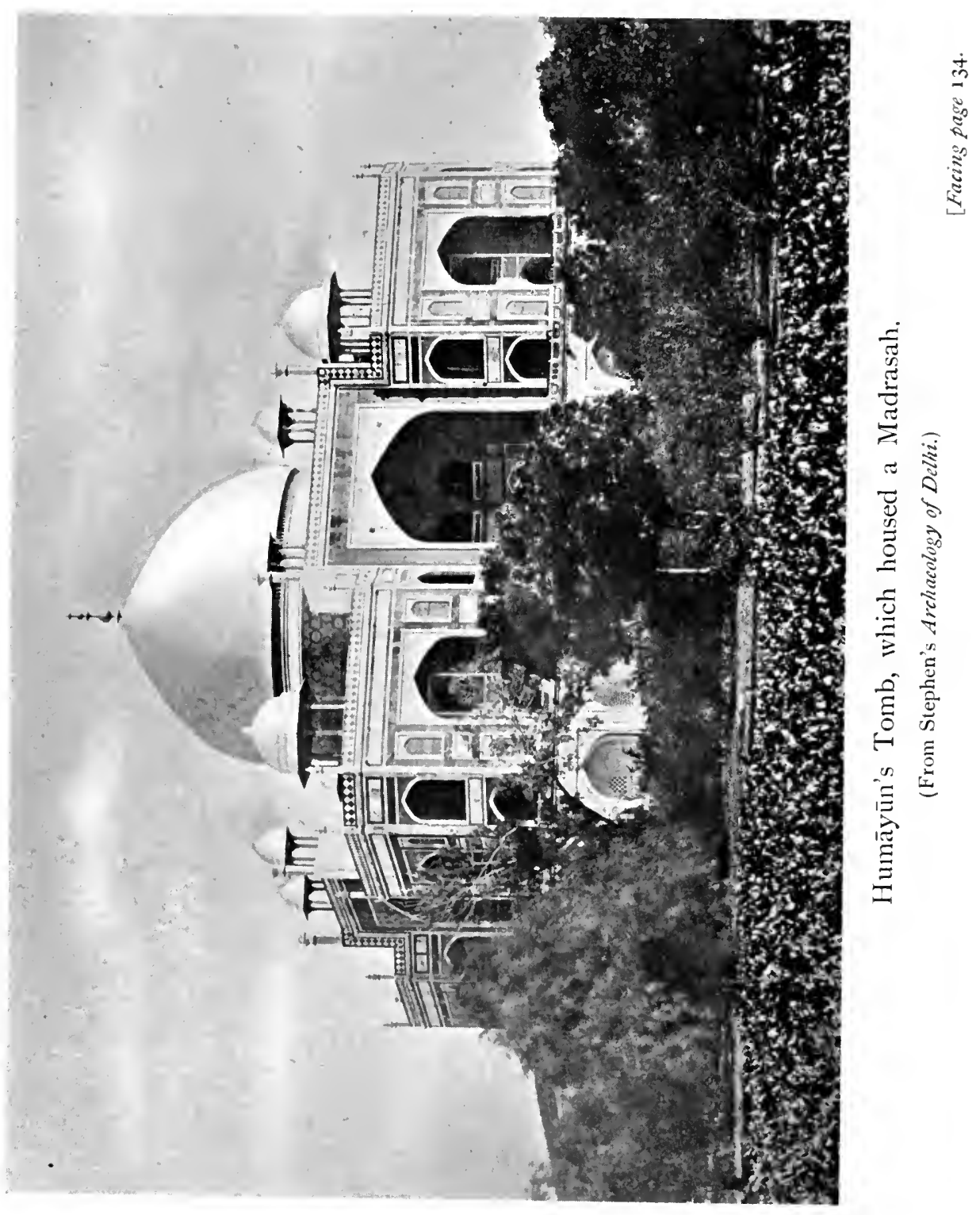


."

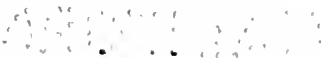




\section{THE MUGHAL DYNASTY}

years, the once probably well-filled rooms have been completely abandoned." 1

1 C. Stephen's Archaeology of Delhi, p. 207; also Fanshawe's Delhi Past and Present, p. 232: "On the top of the building, round the drum below the dome, are a number of rooms and pavilions once occupied by a college attached to the mausoleum, and reminding one of the colony of St. Peter's Dome." 


\section{CHAPTER II.}

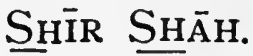

SHIir SHĀH, whose public works have made his reign so very illustrious in spite of its shortness, has left us in the dark about many an interesting point of his rule. But we learn that he used to mix with the learned ('ulamās), with whom he used to take his meals. ${ }^{1}$

About Shīr Shāh's education we learn the following details :-

Hasan, Shīr Shāh's father, had eight sons. Farīd (afterwards Shīr Shāh) and Niz̄ām were born of one mother of a Paṭhān family; the other sons were born of slaves. Hasan neglected his sons. Farid upon this left his father's house and took service as a soldier under Jamāl, the Governor of Jaunpūr. Hasan wrote from Sasarām to Jamāl requesting him to send back his son in order that he might be educated at the former place. Farid could not be persuaded to do so, as he wanted to remain at Jaunpūr which, as he tells

1 Tārīkhi-Shìr-Shāhī of 'Abbās Khān, Elliot iv, p. 413 (Ibid., Garcin de Tassy's transl., p. 143); Wäqi'äti-Mushtāqī, Elliot iv, p. $53^{8}$; and Tärikhi- $\mathcal{F} \bar{a} n-\mathcal{F} a \bar{a} \bar{n}, \mathrm{MS}$. in ASB, leaf 98. 


\section{SHITR SHĀH}

us, was a better place of instruction than Sasarām; but he gave assurance that he would study hard. He soon made much progress in his studies, so that within a short time he could repeat the works of Sa'di. He devoted most of his time to history and poetry, being supported by the generosity of the Governor. ${ }^{1}$ He got by heart the SikandarNämah, the Gulistān, the Bustān, etc., and studied philosophy also. During his reign, whenever learned men came to ask for a maintenance (muddat-māsh), he used to question them about the $H \bar{a}$ shiya-Hindi, for even then he had much liking for books of history and lives of ancient kings. ${ }^{2}$ He learnt Arabic and studied thoroughly the Kafiyāh (a grammatical work) with the commentaries of Qāzī Shahābuddīn and also the biographies of the kings of former times. He used to visit monasteries and colleges, associating with the learned doctors and Shaikhs for self-improvement. ${ }^{3}$

A madrasah was built by this monarch at Nārnaul, ${ }^{4}$ thirty-two miles due west of Bawal, a station on the railway between Hissar and Jaypür. The college is located in one of the greatest buildings of the city. Here stands the tomb of "Hasan

1 Stewart's Hist. of Bengal, pp. 127, 128; also Ferishta vol. ii, p. 100.

2 Muntakhabul-Tawārikh, vol. i, (Ranking), p. 466; and TārikhiShìr-Shāhi, Elliot iv, p. 31 I.

${ }_{3}$ Ibid.

4 In the Patiala State. 


\section{PROMOTION OF LEARNING}

Sive," great-grandfather of Shir Shāh. The tomb

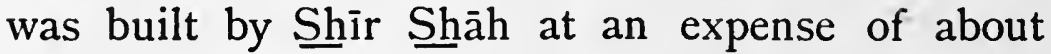
a lac of rupees. An inscription fixes the date of the erection of the madrasah as 927 A.H. (I 520 A.D.). ${ }^{1}$

Shīr Shāh's son had also love of learning. He could compose extempore verses. Two learned men with whom he used to mix often were Shaikh 'Abdul Hasan Kambū and Shaikh 'Abdullāh Sulțānpurī Maqdūm-ul-Mulk. ${ }^{2}$ Shaikh 'Alā'î was a very learned man of the time. He acted as if, as Badā'ūnì says, his motto were-

"Continual learning is requisite with application and exertion; Always by day argument and by night repetition." 3

1 Arch. Survey Report, vol. xxiii, p. 27.

2 Tärïkhi-Fān-Fahān, MS. in ASB, leaf 103.

8 Muntakhabul-Tawärikh, vol. i, (Ranking), pp. 507, 508.

[Note.-For the connection of Shir Shäh's father with "Simla in the province of Närnaul," see Dorn's Annotations on the first part of the History of the Afghans, pp. I00, 10I.] 


\section{CHAPTER III. \\ The Mughal Dynasty (resumed).}

Akbar the Great.

WE are now approaching the reign of the monarch who is justly regarded as one of the greatest sovereigns India has ever seen. Akbar is as much noted for his statesmanship as for his encouragement of letters. He is, however, described by some writers as utterly unlettered. Noer, ${ }^{1}$ for instance, on the authority of a Goanese writer, credits him with no literary education. The Tüzaki-Jahanginir makes the following statements on the subject:-

“My (Jahāngīr's) father used to hold discourse with learned men of all persuasions, particularly with the Pandits and the intelligent persons of Hindustan. Though he was illiterate, yet from constantly conversing with learned and clever persons, his language was so polished that no one could discover from his conversation that he was entirely uneducated. He understood even the elegances of poetry and prose so well that it is impossible to conceive of any one more proficient." ${ }^{2}$

Here, the Emperor is described by his son Jahāngīr, of whom the Tüzak professes to be an

1 Noer's Akbar, vol. ii, pp. 56, 243.

2 Tüzaki-Fahāngīin, by Rogers and Beveridge, p. 33 ; TüzakiFahāngììi, translated by Lowe, p. 26, Fasc. i, (Bibl. Indica). 
autobiography, to be "entirely uneducated." On the other hand, the Wäqi'äti-Jahāngìri, which also styles itself to be an autobiography of the same royal personage, only says that though Akbar was not profoundly learned, yet his conversation with the learned might lead one to believe that he was profoundly learned in every branch of science. It does not say that he was utterly unlettered. The description is as follows :-

"With these Pandits my father (Akbar) was in constant habit of familiar conversation on every subject. He associated, indeed, with the learned among the Hindus of every description; and although he might not have derived any particular advantage from the attainment, he had acquired such a knowledge of the elegance of composition both in prose and verse that a person not acquainted with the circumstances of his elevated character and station might have set him down as profoundly learned in every branch of science." 1

The above two quotations are typical of the two divergent views on the point, the one or the other of which may be found in several other books that profess themselves to be autobiographies of Jahāngīr, e.g. Iqbāl-Nāmah, Tärīkhi-Salìm-Shāhì, Jahāngìr-Nämah, etc., as also in other historical records. The position that Akbar was unlettered cannot however be accepted for various reasons. The fact of Humāyūn's appointment of 'Abdul Lațif as tutor to his son, who, however, did not arrive at the Court till after the death of the Emperor, proves

1 Wäqi'āti-fahāngìrī, Price's transl. (1829), pp. 44, 45 . 
II.]

\section{THE MUGHAL DYNASTY}

the solicitude of the latter for his son's education, and it is not at all likely that he, and after his death, Bairām the guardian, should have left the education of the future monarch in a precarious state. Bairām, it appears, chose 'Abdul Lațif as Akbar's tutor later on. ${ }^{1} \quad$ Moreover, there is distinct record that Pīr Muhammad Khān ${ }^{2}$ and Hājī Muhammad Khān ${ }^{3}$ were also his tutors. Besides, an "entirely uneducated" or "illiterate" person is not in a position to appreciate conversations on learned topics, enjoy abstruse controversies or take part in discussions with learned men, much less to appreciate the elegances of literary compositions. This inference is supported, at any rate, by Abul Fazl who makes some positive remarks about Akbar's education. He says that when the Emperor was four years, four months, four days old ${ }^{4}$ on the 2oth November, I547, he was put to school and Maulānā A'ẓamuddin was charged with the responsible task of educating him. ${ }^{5}$

1 Noer's Akbar, vol. i, p. 127.

${ }^{2}$ Ferishta vol. ii, pp. 193, 20 I ; Elphinstone, vol. ii, (ed. 1841), p. 262.

3 Ferishta vol. ii, p. I94.

4 Humāyūn also went through the same ceremony as noticed above.

5 Akbar-Nämah, vol. i, (Beveridge), ch. xliv, p. 518 . The remarks of Mr. Beveridge are important in this connection, as they are directed towards the solution of this perplexing question: "The truth as far as it can be seen through the maze of Abul Fazl's rhetoric seems to be that Akbar was an idle boy, fond of animals 


\section{PROMOTION OF LEARNING}

Humãyūn himself by his knowledge of astrology fixed the lucky moment; but when the hour came, Akbar concealed himself in a frolic and was nowhere to be found. A'zamuddin did not remain long as tutor, and was dismissed owing to his addiction to pigeon-flying, Maulānã Bāyazīd being appointed in his place. Later on, Muni'm Khān was selected for giving him a training in the military art. ${ }^{1}$

In view of these evidences, we cannot easily accept the view that Akbar lived and died in ignorance of the alphabet. On the other hand, we find some historians describing him as well read in history, and able to compose poetry ${ }^{2}$ and recite several odes of Hāfiz.. ${ }^{3}$

He took much pleasure in Indian fables, and caused the Stories of Mir Hamzah consisting of 360 fables to be written in a beautiful hand and embellished with appropriate pictures affixed to each

and out-door amusements, and that he would not learn his lessons. This is corroborated by Jahāngīr's description of him as an unlettered man, and one who in his youth was fond of the pleasures of the table. It seems probable, too, that Akbar never knew how to read and write. This seems extraordinary in the son of so learned a man as Humāyun, but apparently the latter was not to blame for this. We are told that A'zamuddin, the first teacher, was removed for his addiction to pigeon-flying. This was a taste he communicated to his pupil, if indeed the boy did not inherit it from his great-grandfather 'Umar Shaikh."-Akbar-Nämah, vol. i, (Beveridge), p. $518 \mathrm{n}$.

1 Noer's Akbar (transl. by Annette S. Beveridge), vol. i, p. 125. 2.3 Elliot iv, p. 294; and Ferishta vol. ii, p. 28o. See Addendum. 


\section{THE MUGHAL DYNASTY}

fable. ${ }^{1}$ He kept up his studies throughout his life.

Every day some competent person read to him books which he used to hear from the beginning to the end. He marked with dates the places where he left off, and paid the reader according to the number of pages read. This steady progress in study made him acquainted with many works on different subjects; and Abul Fazl says that there was "hardly a work of science, of genius or of history but was read to His Majesty; and he was not tired with hearing them repeated, but always listened with great avidity." ${ }^{2}$ The following works were repeatedly read by him :-

A khläq-i-Nāsirin,

Kimiyā-i-Sa'ädat,

Qäbüs-Nāmah,

Works of Sharf of Munair,

Gulistān,

Hadìqah of Hakīm Sanā'î̀,

Mașnawi-i-Ma'nawi,

$\mathcal{F} \bar{a} m-i-\mathcal{F} \bar{a} m$,

Bustãn,

Shäh-Nämah,

Mașnawis of Shaikh Nizūmī,

Works of Khusrau and Maulānā Jāmī,

Dïwāns of Khāqānī, Anwarī

and several works on history. ${ }^{3}$

${ }^{1}$ Ferishta vol. ii, p. 280.

2-3 For the above information, vide Blochmann's $\bar{A}^{\prime} \bar{i} n i-A k b a r i$, 
The royal duties being heavy and exacting, a part of the night had to be devoted to them; but the king, with his uncommon thirst for knowledge, had always the patience to devote some time to communion with philosophers, Șūfĩs, and historians, who entertained him with wise discourses. $\mathrm{He}$ always took delight in the society of learned men, and called meetings in which he listened to their discussions on nice points of science, on ancient and modern history, on religions and sects, -in short, "on all matters of worldly interest." It was this love of knowledge that prompted him to build the famous 'Ibādat Khāna in his newly built city of Fathpūr Sìkrī. It stood in the garden of the royal palace with its four halls, the western of which was occupied by Sayyids or descendants of the prophet, the southern by the learned ('ulamās), the northern by Shaikhs and men subject to ecstasy, and the eastern by the nobles and officers of the court, whose tastes tallied with those of one or other of the above three classes. The allotment of separate halls was to remove the ill-feeling that had arisen on one occasion in the assembly for seats and

p. IO3; and Gladwin, p. 85. 'Abdul Qādir, in his MuntakhabulTawärikh, tells us that Naqib Khān often used to read before the Emperor the book called Hayāt-ul-Haiwān. [MuntakhabulTawärikh, by 'Abdul Qadir, vol. ii, p. 207, translated by W. H. Lowe $(\overrightarrow{B i b l}$. Indica).] 


\section{THE MUGHAL DYNASTY}

order of precedence. On Fridays and Sundays, as well as on holy nights, the "Șūfis, doctors, preachers, lawyers, Sunnīs, Shī'as, Brāhmanas, Jains, Buddhists, Chārbāks, Christians, Jews, Zoroastrians and learned men of every belief " 1 were invited to the royal assembly, and each fearlessly brought forward his assertions and arguments. "Profound points of science, the curiosities of history, the wonders of nature, were ever spoken of." Sometimes the discussions grew very hot, ${ }^{2}$ and gave rise to such noise and tumult as exhausted the patience of the royal listener; so that, on one occasion, he proposed to the author of the Tärikhi-Bada'inin the adoption of a repressive measure, which, however, was not carried into effect. Though in this meeting-room much serious discussion was done, yet sometimes the Emperor cut practical jokes, to the annoyance of a certain learned man, Maulānā 'Abdullāh Sulțānpurī, against whom he used to set up Hājī Ibrāhīm and Abul Fazl to argue. Akbar interrupted the Maulānā in the course of his altercation, and hinted to his companions to interfere with interjections and queer observations. But the discussions took a serious turn on such occasions as when Pädri Radalf

1 The accounts differ as to the days on which the meetings took place. For the quotation, see Elliot vi, p. 59. A.N., III, 365, is slightly different.

${ }^{2}$ Specimens of the discussions are given in the Persian work Dabistān. 
(i.e. Rodolpho Aquaviva ${ }^{1}$ ), a missionary from Goa, who by his intelligence and learning occupied a very high place among the Christian doctors, came there to "try a fall" with the Indian savants in an intellectual wrestle. The Emperor was very liberal in his views, and always kept his mind open to any new light that any man, irrespective of his creed or nationality, might bring. This is manifested not only by the admittance of the heterogeneous assembly into the hall to take part in the debate, but also by many other acts of the Emperor. The missionaries of Europe, for instance, came to him and advanced proofs of the truth of their religious principles. The King ordered Prince Murād to learn a few lessons from the Gospel and treat it with due respect, and directed Abul Fazl to translate it. ${ }^{2}$

It was in this 'Ibādat Khāna that a proposal was made one Thursday evening that the King should be recognized as the only temporal and spiritual guide. This proposal raised a storm of opposition, but a compromise was come to, by the bestowal of the title of Mujtahid (the highest authority in jurisprudence) upon the Emperor. ${ }^{3}$

In the 'Ibādat Khāna the Emperor used to

1 Vide Blochmann's $\bar{A}^{\prime}$ ini-Akbari, vol. i, p. I67; and Murray's Discoveries and Travels in Asia, vol. ii.

2 Blochmann's $\bar{A}^{\prime}$ inni-Akbari, pp. 182, 183.

${ }^{3}$ Gladwin, p. 559, f.n. 


\section{THE MUGHAL DYNASTY}

reward those who were declared by the assembly

as the most worthy by giving them handfuls of ashrafis and rupees. Those, however, who did not receive any remuneration on the occasion were given sums of money by handfuls on Friday mornings.

The discussions in the 'Ibādat Khāna often lasted beyond midnight, and sometimes the morning sun peeped into the debating-hall before the rapt assembly, with the Emperor as President, was dissolved. ${ }^{1}$

Great as was the Emperor's zeal for extending the bounds of his knowledge by participating in such learned discourses, no less was his earnestness to foster literature which feeds such knowledge and becomes a valuable asset to the country at large.

Many translations into Persian or Hindī were made of books in Sanskrit and other languages by the Emperor's order.

The Mahäbhärata was ordered to be translated into Persian in $\mathbf{I}^{82}$ A.D. The Emperor assembled some learned Hindus and gave them directions to write an explanation of the work; and for several nights, he himself devoted his attention to explaining the meaning to Naqīb Khān. He also ordered

1 For all the above information $r e$ 'Ibādat Khāna, vide ṬabaqätiAkbarī, Elliot v, pp. 390-391 ; Tärîkhhi-Badā'innī (or MuntakhabulTawärikh), Elliot v, pp. 517-519 and 526-529; Abul Fazl's Akbar-Nãmah, Elliot vi, pp. 59, 60. 


\section{PROMOTION OF LEARNING}

'Abdul Qãdir, the author of the Tärihki-Badä'uni, to help Naqib in his work. In three or four months, two out of the eighteen sections of the work were translated. Mullā Sheri and Naqīb Khān then accomplished another portion, while Sulțān Hảjī Thāneswarī did also some other portion. Shaikh Faizị was directed to translate the rough translation into prose and verse, but he did not finish more than two sections. Hājī then revised Faizin's work, but was dismissed before he finished a hundred sheets.

This translation, which was a sort of abstract of the voluminous work, was called Razm-Nämah (Book of War) ; and after being neatly engrossed, it was embellished with pictures. Abul Fazl wrote a preface covering two sheets. The nobles were ordered to take copies. ${ }^{1}$

The translation of the Rämäyana into Persian was completed by 'Abdul Qādir in I 589 A.D., after a labour of four years. ${ }^{2}$

The Atharva Veda ${ }^{3}$ was translated into Persian by Hạjjī Ibrāhìm Sarhindī, the Lilãvati by Faizị,

1 Gladwin's $\bar{A}^{\prime} \bar{i} n i-A k b a r \bar{i}$, p. 85 ; and Tārīkhhi-Badä'īnī, Elliot v, pp. 537,538 .

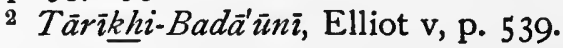

3 'Abdul Qãdir says that the work of translation was first entrusted to a learned Brāhmana convert to Muhammadanism, who came from the Deccan, and to 'Abdul Qādir himself They failed, and then the task was imposed on Shaikh Faizịi, and next on Hājī Ibrāhìm.-Lowe's Muntakhabul-Tawärīkh, vol. ii, p. 216. 


\section{THE MUGHAL DYNASTY}

the $T \overline{a j a k}$, a treatise on astronomy, by Mukammal Khān Gujrātī, the Wäqiäti-Bäbari in Turkish by Rahīm Khān Khānān, and the History of Kashmìr in Sanskrit by Maulānā Shāh Muḥammad Shähābādī. ${ }^{1}$ The Jämïul-Rashīdì was translated by 'Abdul Qãdir. The Majma'ul-Buldān, a geographical work in Arabic, was rendered into Persian by several scholars such as Mullā Ahmad T'hat'hah, Qāsim Beg, Shaikh Munawwar and 'Abdul Qādir. ${ }^{2}$ The Haribanisa was also translated into Persian, while Naṣrullah Muștafā and Maulānā Husiani Wä'iz had made a Persian rendering of the Pañchatantra, which was called Kalilah-Damnah. The translation of the last-named work was difficult, and so an easier adaptation under the title of 'AyärDänish was also made.

The work delineating the love of Nala and Damayantī was translated into Persian verse after the model of Layalā and Majnūn.

While the Court was at Shirgarh, otherwise

1 "'Abdul Qādir made an abridgment of the history of Kașhmir, which is said to have been translated from 'Hindī' (Sanskrit) by Mullā Shāh Muhammad Shāhābādī, and was called Rauzahi-Ṭāhirin, but apparently not the Rajjataraingin $\bar{i}$, for the translation of that work is usually attributed to Maulānā Imāmuddin. According to Professor Wilson there were frequent remodellings or translations of the same work, but among those he notices he does not mention the one by Mullā Shāh Muhammad Shāhābādī."-Elliot v, p. 478 ; Asiatic Researches, vol. xv, p. 2 ; and Blochmann's $\bar{A}^{\prime}$ iniAkbari, vol. i, p. 106.

2 Tärīkhi-Badā'ūnī, Elliot v, p. 478. 
called Qanauj, 'Abdul Qādir was given instructions by the Emperor to translate the Sinhäsana Battisi into prose and verse. A learned Brāhmana was appointed to interpret the work to Qãdir. When the translation was finished it was called KhiradAfz $\bar{a}-N \bar{a} m a h$, a name which contains the date of its composition. It was then placed in the royal library. ${ }^{1}$ The Shăh-Namah was turned into prose, and the Hayatul-Haiwān was also translated. ${ }^{2}$ Abul Fazl, we have noticed before, was charged with the task of translating the Gospel.

A part of the Astronomical Tables of Ulugh Beg which we have noticed in Bābar's reign was translated under the supervision of Amīr Fathullāh Shìrāzì, as also the Sanskrit works,-the Kishn Foshi, the Gangādhar, and the Mahes-Mahananda under Abul Fazl. ${ }^{3}$ Bäbar's Memoirs was translated from Turkish into Persian by 'Abdul-Rahịm Khān Khānān in 1590 A.D. ${ }^{4}$

The Tarikhi-Alfi, ${ }^{5}$ or the history of 1000 years,

1-2 Tärīkhi-Badā'uñi, Elliot v, pp. 483, 484 and 513 .

s Blochmann's $\bar{A}^{\prime} \overline{i n i}$-Akbari, p. IO4.

4 Elliot iv, p. 2 I 8.

5 "The literary circle which followed the Imperial Court appears to have been peculiarly active during its sojourn at Lahore. It was here that the voluminous history of Muhammadanism from the earliest period up to the thousandth year of the Hijri era compiled by the order of the Emperor was finished and revised; and it was here that the translation of the Mahäbhärata and the Rājataraingin̄ into Persian was undertaken," p. 10, A Brief Account of the History and Antiquities of Lahore, I873 (author not mentioned) - [in the Calcutta Imperial Library]. 
was begun by Naqīb Khān and others; Maulānā Ahmad T'hat'hahwi had a great share in the compilation. Ja'far Beg and Aș̣af Khāan finished it.'

The descendants of Tīmūr seem to have had a great partiality for writing their memoirs, e.g. Bābar and Jahāngīr. But those who did not write their own biographies provided for a record of their lives and actions to be written. This was done in the case of Akbar. The Wāqi'navīs used to make a ta'liqah of the daily actions of the Emperor; for instance, what he ate or drank, what books were read to him, and so forth. The diary had to be approved by Akbar and several other officers before it could be taken as an authentic record fit for preservation. This office of Wāqi'navīs also existed in former reigns, but, according to Abul Fazl, it was not turned to any useful purpose. ${ }^{2}$

The Emperor took much delight in the collection of books in his library, a feeling natural to all bibliophiles. Some of the books in the royal library were kept in the harem and the rest in the outer apartments. He made several provisions for the good management of his library, and its books were classed under sciences and histories. ${ }^{3}$

${ }^{1}$ For the above information, vide Gladwin's $\bar{A}$ 'ini-Akbarī, pp. $85,86$.

${ }^{2}$ Gladwin, pp. 177, 178.

${ }^{3}$ Ibid., pp. 84, 85; Mullā Pîr Muhammad was at one time the superintendent of the library (Târi $\underline{k} h i$-Akbari, MS. in ASB, leaf 42 ). 


\section{PROMOTION OF LEARNING}

The Emperor acquired a library belonging to I'timād Khān Gujrātī during the conquest of Gujrāt. It contained many fine books which were placed in the royal library, but were subsequently distributed by the Emperor among learned and pious men. 'Abdul Qādir was presented with a copy of the Anwarul-Mishkat. ${ }^{1}$

When Faizi $\overline{1}^{2}$ died, he left a library containing 4600 volumes, some of which were exquisitely copied with extravagant care and expense. Most of them were autographs of their respective authors or were at least copied by their contemporaries. They were all removed to the King's Library, and catalogued and numbered in three different sections. The first section included poetry, medicine, astrology and music; the second, philology, philosophy, Șüfĩism, astronomy and geometry; and the third, commentaries, traditions, theology and law. There were Ior copies of the poem Nal-Daman in Faizị’'s collection. ${ }^{3}$

1 Tārikhhi Badā'ünī, Elliot v, p. 519; Tärīkhi-Akbarī, MS. in $\mathrm{ASB}$, leaf 58 .

2 It is gratifying to learn that the houses at Fathpūr Sikrī of both Faizị and Abul Fazl, which stand very near each other, are now being used as a Zilla School, and have not been appropriated to some other purpose (vide Smith's Fathpiur Sikri, pt. iii, p. 29).

3 Tärikhi-Badä'üni, Elliot v, p. 548. Though we learn that there was an Imperial Library, which grew richer in its collection by additions made by the Emperor, we are quite in the dark as to the number of volumes in it, and hence unable to compare it with the libraries established at such centres of Muslim learning as 


\section{THE MUGHAL DYNASTY}

In the Agra Fort there is a room which is pointed out as the place where a library was located. Mr. Havell thus describes its situation :-

"Passing through these [i.e. the small rooms known as Akbar's apartments adjoining the Samman Burj] we enter a long room known as the Library, in which a not very successful attempt was made some years ago to restore the painted decoration." 1

While dwelling on libraries, we should not omit to notice how painting was laid under contribution to beautify and illustrate the books in the royal library. Persian books in prose and verse were richly illuminated by eminent artists. The Qișah Hamzah in twelve volumes was profusely illustrated by so many as 1400 paintings; and similarly, among many others, the following works were embellished, viz. : Changīz-Nämah, Zafar-Nämah, Iqbäl-Nämah,Razm-Nämah² (i.e.theMahäbhärata), Ràmàyana, Nala-Damayantī, Kalïlah-Damnah (Pañchatantra) and the 'Ayär-Dänish which was an easy Persian version of the Pañchatantra. ${ }^{3}$ Ingenious artists were employed to embellish the

Cordova, Cairo, Merv, Bukhārā, Baghdād, etc. For an account of these libraries see Justice Khudā Bakhsh Khān's Islämic Libraries.

${ }^{1}$ E. B. Havell's Handbook to Agra and the Taj, Sikandra, Fathpuir-Sikri and the Neighbourhood, p. 66.

${ }^{2}$ The famous manuscript of Razm-Nâmah is said to have cost Akbar about $£ 40,000-$ a sum which in our days would be much greater. It is now at Jaipür (see Martin's Miniature Painting and Painters of India, Persia, and Turkey, vol. i, p. 127).

${ }^{3}$ Gladwin's $\bar{A}^{\prime}$ ini-Akbarī, p. 87. 


\section{PROMOTION OF LEARNING}

margins of books, and much labour was expended upon the bindings. ${ }^{1}$

Akbar's taste for the fine arts was no less than his love of learning. From the very commencement of his reign, he encouraged painting, and in order that a number of painters might by emulation among themselves be more and more proficient in their art, he established a painting gallery in which they might assemble and ply their art. Every week, the Däroghäs brought to His Majesty the performance of every artist, and the Emperor rewarded him with bonuses and increase of salary in proportion to his merit. The most eminent painters attached to the royal Court were :-

Mīr Sayyid 'Alī Tabrīzì,

Khwājah 'Abdul Șamad Shīrīnqalam Shīrāzī,

Daswant, the son of a pälki-bearer,

Basāwan,

Kesū,

Làl,

Mukund,

Mushkin,

Farrukh the Qalmāq,

Mādhū,

Jagan,

Mahes,

1 Blochmann's $\bar{A}^{\prime}$ ini-Akbarī, pp. $96 \mathrm{ff}$; Gladwin, p. 89. For a list of painters in Akbar's Court, and their paintings still preserved, see Martin's Miniature Painting, etc., vol. i, pp. I27-131. 


\section{THE MUGHAL DYNASTY}

Khemkaran,

Tārā,

Sāṇwlah,

Haribans

and Rām.

The portraits of all the principal officers of the Court were made by the Court painters, and were bound up into a thick volume. ${ }^{1}$

The sister art of music obtained also a great encouragement from the Emperor and reached a high excellence in his reign. There were numerous musicians at his Court, Hindus, Irānīs, Turānis, Kāshmīrīs, both men and women. These were divided into seven classes, one for each day in the week. $^{2}$ The world-renowned singer, Miyān Tānsen, a Hindu convert to Islām, whose tomb at Gwalior has become a place of pilgrimage to the Indian musicians, was a Court singer of Akbar. There flourished at the time, the great singer Hari Dās the master of Tānsen, and Rām Dās the second Tānsen, who hailed from Lucknow and received, it is said, on one occasion, a present of a lac of rupees from Khhān Khānān. ${ }^{3}$ Besides Tānsen and Rām Dās there were at Akbar's Court the following other singers ${ }^{4}$ :-

1 For the above information, vide Blochmann, pp. 107, 108.

2 Ibid., p. 612.

3 Tārikhhi-Badä'ūni, Elliot v, p. 482 ; and N. A. Willard's Treatise on Hindu Music, p. 214.

4 Willard, pp. 2 I 3 ff., and Blochmann's $\bar{A}^{\prime} \bar{i} n i-A k b a r \bar{i}$, pp. 61 2, 6 1 3. 


\section{PROMOTION OF LEARNING}

\section{Subhān Khān, \\ Srigyān Khān, $\}$ of Gwalior, \\ Miyān Chānd,}

Bichitr Khān, brother of Subhān Khān,

Muḥammad Khān Ḍhārī,

Dā'ūd Ḍhārị,

Sarud Khān,

Miyān Lāl, $\}$ of Gwalior,

Tāntarang Khān, son of Tānsen,

Bilās, another son of Tānsen mentioned by the Bädshāh-Nämah, ${ }^{1}$

Mullā Isḥāq Ḍārī,

Nānak Jarjū of Gwalior,

Sūr Dās, son of Rām Dās,

Chānd Khān of Gwalior,

Rangsen of Agra,

Raḥmatullah, brother of Mullā Isḥāq, and

Pīrzādah.

The following were the noted players on different musical instruments :-

Bīr Maṇal Khān, of Gwalior, player on the sarmandal;

Shihāb Khān and Purbīn Khān, performers on the bin;

Ustā Dost, of Mashhad, player on the flute (nai);

Shaikh Dāwan Dhārī, performer on the karanā;

$1 B \bar{a} \underline{\text { sh }} \bar{a} h-N a \bar{m}$ ah, by 'Abdul Ḥāmid Lāhaurī, vol. ii, p. 5 . 
Ustā Yūsuf of Hirāt,
Sulțān Hāshim of Mashhad, | players on the Ustā Muḥammad Aminn and tambuirah;

Ustā Muḥammad Husain

Mìr Sayyid 'Alī of Mashhad and players on Bahrām Qulī of Hirāt, $\quad$ the ghichak; Tāsh Beg, of Qipchāq, player on the qübüz;

Qāsim, who invented an instrument intermediate between qübüz and rubäb;

Ustā Shāh Muhammad, performer on the Surnā, and Mir 'Abdullāh, on the qänün.

At the time of Akbar, the art of music reached its noon-day splendour. The vocal music with its various rāgs and räginiss, many of which have now been forgotten for want of cultivation, received a good deal of attention, while instrumental music with its various musical instruments was equally cared for. ${ }^{1}$

In the domain of music, it is very perceptible how the Hindus and the Muhammadans were horrowing from one another, each community enriching the other with the precious store it possessed. This process of intermixture was not new in the time of Akbar, but dated from a long time back. The history of Indian music, after the advent of the Muhammadans, unfolds a chapter of co-operation and intercourse between the two communities socially and politically. Khiyäl, for instance, which is associated with the name of

1 Vide Willard, pp. IoI ff. 


\section{PROMOTION OF LEARNING}

Sulțān Husain Sharqī, of Jaunpūr, as its inventor, has become an important limb of Hindu music, while Dhrupad has engrafted itself on Muhammadan music ${ }^{1}$ the state of Indian music in former times, no less than its present eclectic condition, testifies a good deal to this intermixture taking place through centuries.

Music was at this time cultivated in different parts of the country. We have already seen how Bãz Bahādur, of Mālwa, devoted himself to its improvement and encouragement. In Kashimir, according to Abul Fazl, there were now many delightful singers."

It was not merely the Emperor or the chiefs of the provinces who turned their attention to this fine art, but the nobles also entertained themselves and their families by this means of diversion. ${ }^{3}$

Caligraphy as a branch of fine art was long cultivated by the Muhammadan rulers, and at the time of Akbar the following modes of writing were prevalent $^{4}:-$

Suls,

Tauqi,

Muḥaqqaq,

Naskh,

Raihān,

attributed to Ibni-Muqlah,

920 A.D.

Riqā', and

Ghubār,

1 Vide Willard, pp. ror ff.

${ }^{3}$ Gladwin, p. 735 .

${ }^{4}$ Blochmann's $\bar{A}^{\prime} \overline{i n} i-A k b a r \bar{i}$, p. 99. 
II.]

\section{THE MUGHAL DYNASTY}

Some, however, look upon Yākūt Musta'șamī as the inventor of the Naskh character. Ta'liq is another mode of writing, and attributed to Tàji Salmānī. Ashhraf Khān, Mīr Munshī to Emperor Akbar, was very proficient in this sort of handwriting. The well-known Nasta'lī character which is all curve and said to have been composed from the Naskh and Ta'līq by Khwājah Mìr 'Alī Tabrīzì in the time of Tìmūr, had existed, according to Abul Fazl, before the time of that monarch, and so Mìr 'Ali could not be the composer of the character.

Akbar gave great encouragement to good penmanship, particularly to the Nasta'liq hand. Before the invention of printing, clear and neat handwriting was a necessity; and this was the principal reason why so much stress was laid upon this art. The most excellent penmen attached to Akbar's Court wereMuhammad Husain Kashmīī Zarrīnqalam, Mullā Mīr 'Alī, and his son, Maulānā Bāqir, Muhammad Amīn Mashhadí,

Mìr Husainī Kulankī,

Maulānā 'Abdulḥayy,

Maulānā Daurī,

Maulānā 'Abdul-Rahịim,

Mīr 'Abdullāh,

Nizāmīì Qazwīnī,

'Alī Chaman Kashmīrī,

Nūrullah Qāsim Arrslān. ${ }^{1}$

1 Blochmann, p. 103. 
Emperor Akbar paid very great attention to the education of his sons and grandsons, and appointed learned men of very high reputation to superintend their studies. Quṭbuddīn Khān and 'Abdul-Rahīm Mīrzā were Salīm's tutors ; Faizī and Sharīf Khān, Murād's; and Sayyid Khān Chāghtāīî, Dāniyāl's ; Murād received instruction in Christian doctrine, and read the New Testament with some of the Jesuit Fathers. The Emperor placed one of his grandsons under the tuition of Abul Fazl and a Brāhmana. ${ }^{1}$

Akbar's reign marks a new epoch for the system introduced for imparting education in schools and colleges. The innovations and improvements that were introduced were the outcome of the liberal heart of the Emperor, which made its influence felt in so many other directions. We see in Akbar, perhaps for the first time in Muhammadan history, a Muslim monarch sincerely eager to further the education of the Hindus and the Muhammadans alike. We also notice, for the first time, the Hindus and the Muhammadans studying in the same schools

1 Noer's Akbar, vol. ii, p. 247.

Faiẓī was once appointed Dāniyāl's tutor [vide MuntakhabulTawärikh, vol. ii, (Lowe), p. 297]. "Akbar committed the education of his favourite son Murād to Father Monserrat to be instructed in the sciences and religion of Europe. One day the young prince began his lesson in the Emperor's presence with these words, 'In the name of Almighty God.' 'Add, my son,' said Akbar, 'and of Jesus Christ, the true Prophet.' "-Hough's Christianity in India, p. 270. 


\section{THE MUGHAL DYNASTY}

and colleges. Besides this reform, the monarch introduced some other changes in the modes of study, in the curriculum, etc., the good results of which made Abul Fazl pride himself on the fact that "all civilized nations have schools for the education of youths; but Hindustan is particularly famous for its seminaries." 1

The boys were first taught the Persian alphabet along with accents and marks of punctuation. As soon as this was mastered, which did not take more than two days, they were taught the combinations of two letters. After a week, they had to read short lines of prose or verse containing religious or moral sentiment, in which those combinations frequently occurred. They must strive to read these themselves with occasional assistance from the tutor. Then, for a few days, the master proceeded with teaching a new hemistich, and in a very short time, the boys could read with fluency. The teacher gave the young students four exercises daily, viz. the alphabet, the combinations, a new hemistich or distich, and repetition of what they had read before. This method proved very successful, so that what usually took them years was now accomplished in a few months. The sciences were taught in the following order:morality, arithmetic, accounts, agriculture, geometry, longimetry, astronomy, geomancy, economics, the

1 Gladwin, pp. 192, 193. 
art of government, physic, logic, natural philosophy, abstract mathematics, divinity and history. The Hindus read the following books on their subjects of learning, viz.: Vyäkarana, Vedänta and Patañjali, every one being educated according to his particular views of life and his own circumstances. These regulations, says Abul Fazl, gave a new form to the schools, and made the colleges lights and ornaments of the empire. ${ }^{1}$

The Emperor was not satisfied with these healthy educational changes alone, but multiplied the number of educational institutions in his empire by " continually giving employment to a number of hands in erecting fortifications and palaces, colleges and masjids." 2

A big college was founded by Akbar at Fathpūr Sìkrī, " on the hill, the like of which few travellers can name." ${ }^{3}$ Lālā Sīlchānd perhaps means this madrasah when he says, "Akbar on his return from Ajmere made Fatḥpūr his capital, and built many buildings there, including madrasah, khānqah, etc." 4 Besides this college, it appears that

1 Blochmann's Á'ini-Akbari, pp. 278, 279; Gladwin, pp. 192, I93.

2 Gladwin, p. 146.

${ }^{3} \bar{A}^{\prime}$ ini-Akbarī, vol. ii, (Jarrett), p. I80.

4 Tafrīhul-'Imārāt, by Lālā Sìlchānd, MS. in ASB, leaf 243. The Persian MS. 'Imārätul-Akbar, by Chahtar Mal, which gives a detailed account of the edifices built by Akbar, and which has been so highly spoken of by Mr. Beale in Proc. A.S.B. (1875), pp. I17, 


\section{THE MUGHAL DYNASTY}

there were several other madrasahs in the city, founded at the instance of Akbar. ${ }^{1}$

In Agra also there were several madrasahs, where several professors brought from Shirrāz, the famous centre of Muslim learning, used to teach. ${ }^{2}$ Silchānd records that a very big madrasah existed even up to his time in Agra. Akbar engaged a philosopher of Shīrãz for this institution. ${ }^{3}$

It should be remarked that the colleges in Delhi were not all residential. The learned scholar Shaikh 'Abdul Haqq, who at twenty years of age mastered most of the customary branches of knowledge and learnt the whole of the Qur'an by heart, ${ }^{4}$ informs us that he used to go twice a day to a college in Delhi, morning and evening, during the heat of one season and the cold of another, returning to his own house for his meal only for a short time. His lodging was two miles away from the college, and

I I 8, very probably mentions the Sìkrī College. I regret I could not use this rare MS., as the one belonging to ASB procured by Prof. Blochmann is missing.

1 Vide Khuläsatul-Tawärikh, as quoted in J. Sarkar's Topography of the Mughal Empire, p. 24, corresponding to KhulāsatulTawārikh, MS. in ASB, leaf 25.

In Gujrāt there was a madrasah built by Șādiq Khān. Shaikh Wajīhuddin Ahmad used to teach here, and when he died he was buried within this college (I589 A.D.).-Mir'äti-Ahmadi, vol. ii, p. 45.

2 Tafrìhul'Imārāt, MS. in ASB, leaves 39, 4I.

${ }^{3}$ Ibid., leaf $4 \mathrm{I}$.

4 Bādshāh-Nāmah of 'Abdul Hāamid Lāhaurī, Elliot vi, p. I76. 


\section{PROMOTION OF LEARNING}

so he had to travel eight miles a day-indicating indeed a great ardour for learning on his part. ${ }^{1}$

While speaking of the schools and colleges of these days, we should not lose sight of the educational work done by distinguished learned men, teaching pupils in their houses. They supplemented, as already pointed out, the educational work done by the literary institutions, and provided a field for post-collegiate studies. It was thus that 'Abdul Qãdir, the author of the Tärikhi-Badā'uni completed his education at Agra, where he went with that purpose, leaving his house at Basāwar; and there he lived and studied in the house of his preceptor, Mìhr 'Alī Beg. ${ }^{2}$ This system of imparting education has been in vogue from remote times, specially for those branches of arts and sciences for which schools or colleges generally made no provision, e.g. music, painting and other arts, the various industries, studies in the higher branches of a subject, and so forth.

The Emperor Akbar, like Fīrūz Shāh, was always ready to encourage art and reward the ingenuity of those who produced mechanical works of curious contrivance. The ingenious works which he is said to have rewarded were such as would

1 Akhbārul-Akhyār, by 'Abdul Haqq, Elliot vi, p. 176, corresponding to its lithographed ed., p. 357.

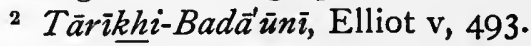




\section{THE MUGHAL DYNASTY}

have done credit even to an artisan of the twentieth century. ${ }^{1}$

In Akbar's reign, as also during the reigns of his predecessors, the promotion of education found its supporters, not in the Emperor alone, but also in private individuals belonging to the nobility or the middle class. The Madrasah, about which I shall speak presently, was built by Māham Anaga (the wet-nurse of Emperor Akbar, and the mother

1 "One of the wonders of art which was exhibited this year, 1003 A.H. (I 594 A.D.), was the work of Sayyid Husain Shìrāzì. He used to stand with a box in his hand, and when any one gave him a rupee, he threw it into the box, and it kept on rolling until it fell to the bottom. Upon this a parrot. which was chained to it, began to speak and two fowls began also to cackle at one another. Then a small window opened, at which a panther put out its head and let a small shell fall from its mouth into a dish which was placed on a lion's head, and the shell then came out of the lion's mouth. A short time elapsed when another window opened and another lion came forth, took the shell into its mouth and retired, and the windows again closed. Two elephants then appeared with perfect trunks, and there were also two figures of men who sounded drums. A rope then thrust itself forward and again retreated of its own accord. Two other men then advanced and made obeisance. Shortly after, another window opened and a puppet came forth with an ode of Hāfiz in its hand, and when the ode was taken away from the puppet, it retired and the window was closed. In short, whenever a piece of money was placed in the hands of Husain Shīrāzi, all these marvels were exhibited. The King first gave a gold mohar with his own hand and witnessed the sight. He then ordered his attendants to give a rupee each. The odes which were presented were given by the King to Naqib Khān, by whom they were read out. The exhibition lasted for several nights." $-Z u b d a t u l-T a w \bar{a}-$ rikh, by Shaikh Nūrul Haqq, Elliot vi, p. 192.

\section{I65}


of Adham-Khān) in the year 969 A.H. (I56r A.D.). ${ }^{1}$

It is certainly remarkable and creditable that she should think of promoting the cause of education in this way. The masjid attached to this Madrasah was very fine, as the following description will show. It was built of

"rubble and plaster, with the ornamented parts painted by the use of red dressed stone and granite; the gate, now partly ruined, must have once been very fine. The masjid inside was profusely ornamented with coloured plaster and glazed tiles, though now most of it has been stripped. The façade of the masjid and gateway was also ornamented with coloured medallions and carved stone flowers ; the colours used were blue, yellow, red, purple, white, green, black, grey. It has one central dome on a low neck and very peculiar pinnacle, greatly resembling that of Qil'ah Konā Masjid. The walls of the masjid are plumb, but the towers slope, and it has projecting eaves in front as in Moti-ki-Masjid. A peculiarity of this masjid was its cloisters." ${ }^{2}$

Picturesque as the Madrasah looked with its ornamented mosque, it is an irony of fate that its name should ever afterwards be associated with an incident that marred its stainless beauty. In the eighth year of the reign of Akbar, an attempt was made on the life of the Emperor Akbar from the roof of the college, which the author of the TabaqatiAkbari ${ }^{3}$ describes as follows :-

1 C. Stephen's Archaeology of Delhi, pp. 199 ff.; also $\bar{A}$ särulȘanādìd, by Sayyid Aḥmad, 3rd chap., p. 54. A.N., I, $134 n$. takes Māham as dry-nurse.

${ }^{2}$ Beglar, quoted in C. Stephen's Archaeology of Delhi, pp. 199, 200.

3 Tabaqāti-Akbari, MS. in ASB, pp. $260 \mathrm{ff}$. 


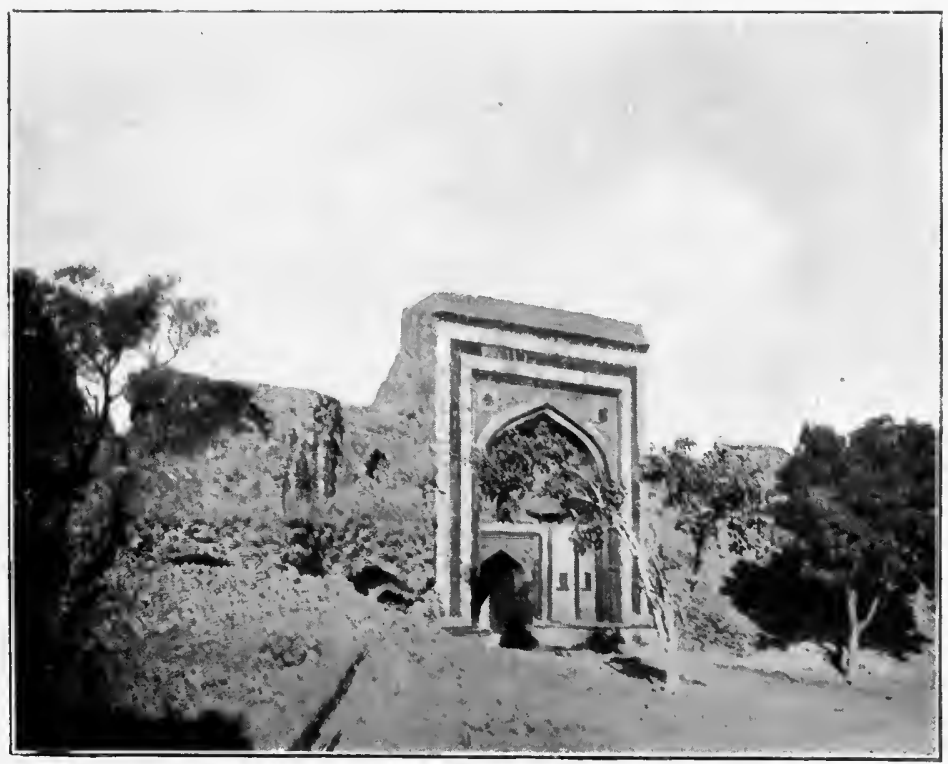

Madrasah of Māham Anaga (Akbar's Wet-Nurse). [From Hearn's Seven Cities of Delhi (Thacker, Spink \& Co.).]

[Facing page 166. 
$\therefore \because \quad \because \quad+\because \vdots \%$

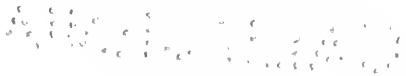




\section{THE MUGHAL DYNASTY}

"When Sharafuddin Husain fled from Court to Nagor, he had a slave, by name Kukah Fūläd, one of the slaves of his father, who at all times secretly did everything in his power to injure the Emperor. This wretched man came into the royal camp and was constantly on the watch for an opportunity. When the Emperor returned from his hunting excursion, and passing through the bazar of Delhi came near the Madrasah of Māham Anaga, this bloodthirsty fellow shot an arrow at His Majesty, but by the mercy of God, who watched over the Emperor's safety, it did not inflict a severe wound, but merely grazed the skin. The attendants of the Emperor instantly fell upon the traitor, and with strokes of sword and dagger, sent him to hell." 1

This reminds one of what had happened to the Emperor Humāyūn a few years before. Like Akbar, he narrowly escaped being shot while reposing in a garden near Fathpūr Sìkrī during a brief halt. $^{2}$

The Madrasah is now in ruins, but the dilapidated cloisters are still to be seen here and there. It stands almost in front of the western gate of Purāna Qil'ah, and near the supposed site of the western gate of the Delhi of Shìr Shāh. ${ }^{3}$

${ }^{\prime}$ C. Stephen's Archaeology of Delhi, p. 200; Akbar-Nämah, vol. ii, (Beveridge), p. 3 I2.

Khāfi Khān, in his Muntakhabul-Lubāb (Bibl. Indica), Pt. i, p. 164, mentions the incident, but not the madrasah.

${ }^{2}$ See Jauhar's Tagakiratul-Wäqi'āt, transl. by Stewart, p. 24 .

${ }^{3}$ C. Stephen's Archaeology of Delhi, p. 199. The inscription on the mosque is to the following effect:- "In the time of Jaläluddin Muhammad, who is Great Akbar among the just kings, Māham Begam, the root of purity, laid the foundation of this house for good men : but the building of this gracious house was helped by Shahāābuddīn Ahmad Khān Bāzil ; what blessings there are in this auspicious building that its date is found in the words, KhairulMandzil, i.e. 'Blessed among Houses'!" See also S. Ahmad. 


\section{PROMOTION OF LEARNING}

Besides this college of Māham Anaga, we notice another college of one Khwājah Mu'in. Here Mìrzā Muflis Samarqandì taught for three years from I57 I A.D. ${ }^{1}$

Akbar used to encourage the learned by giving them rewards and stipends. When he conquered Kashmir, he showed some learned men of Kashmir this liberality. ${ }^{2}$ His fame spread far and wide throughout his dominions for his literary encouragement in various ways, for which he was revered not only by the Muhammadans, but also by men of other persuasions. To quote an instance : Madhavāchāryya, a Bengali poet of Triveṇi, contemporary with the Emperor, speaks of him in his Chandi-Maingal in terms of very high regard. ${ }^{3}$

The Tabaqäti-Akbari ${ }^{4}$ gives a list of a number of learned men and poets, some of whom received encouragement from the Emperor. Here are the names of a few of them :-

1 Muntakhab-Tabaqâti-Akbari (bound up in the same volume with Muntakhabül-Mir'ät-ul-'Alam), MS. in Boh. Coll.,p. 20. The work only mentions that the madrasah was in Hindustan.

2 Tärikhi-Kashmir (or Gauhar-i-'Alam), by Muhammad Aslam, 5 th Tabaqah.

3 Mr. Dinesh Ch. Sen's Hist. of Bengali Literature, pp. 335, 336 (new ed.).

4 Tabaqāti-Akbari, MS. in ASB, pp. 769-799. In Blochmann's $\bar{A}^{\prime}$ ini-Akbari, pp. $537 \mathrm{ff}$., a list is given of names of the literati of this time, culled from the Tabaqātī-Akbari, Mir'ätul-'Álam and Badā'ūni. 
II.]

THE MUGHAL DYNASTY

(I) Amìr Mìr Taqi Sharîfi,

(2) Mullā Sayyid Samarqandī,

(3) Shaikh Abul Fazl,

(4) Mullā 'Alāuddīn Hindī,

(5) Mullā Șādiq Halwā'î,

(6) Mīrzā Muflis,

(7) Ḥāiz Tāshhqandī,

(8) Mullā 'Abdullāh Sulțānpūrī,

(9) Shaikh 'Abdul Nabì Dihlawī,

(Io) Qāẓi Jalāluddīn Hindī,

etc., etc.

The list contains ninety-five names altogether. The Tabaqät has a list of names of about ninetythree poets of the time.

'Abdul Rahìm, the son of Bairām Khān, was a great patron of letters. He could write volubly Persian, Turkish, Arabic and Hindi. He was a poet too, and as such, known as Rahim. He presented to Akbar a Persian translation of the Memoirs of Bābar in I 590. ${ }^{1}$ Bairām was educated at Balkh, a centre of Persian scholarship. ${ }^{2}$ Before his arrival in India, he had opened tutorial relations with Maulānā Zainuddīn Mạ̣mūd Kāmāngarh, finishing Yüsuf and Zulaikhā, and other books under his tuition. ${ }^{3}$

Mīrzā Iraj, son of 'Abdul-Rahịim Khān Khānān

1 Noer's Akbar, vol. ii, p. 89.

2 Ibid., vol. i, p. 126.

3 Muntakhabul-Tawärikh, vol. i, (Ranking), p. 588. 
was also well educated. Maulānā Khairuddīn Rūmī, a pupil of Mīrzā Jān Shīrāzī, ${ }^{1}$ was once his tutor. He was also under another preceptor who had taught for twenty-three years in a madrasah at Aḥmadābād. ${ }^{2}$

'Abdul-Rahìm had a library to which many learned men used to come for study and self-improvement. $^{3}$ We are left in the dark as to how big his library was. Pictures of old libraries of Muhammadan gentlemen of India or of any other place are very rare. I append hereto a representation of an ancient library at Hulwān, in Persia, a country very near to Rahīm's father's birthplace, Badakshan. It satisfies our curiosity as to several points regarding the internal arrangement of the library. ${ }^{4}$

Many people used to come to Khān Khānān to become his pupils. ${ }^{5}$ The Ma'așiri-Rahìmī mentions the names of about ninety-five learned men who were favoured with his patronage in various ways. ${ }^{6}$

We have now seen from the variety of evidence and information adduced above that Akbar occupied

$1 M a^{\prime} a \bar{s}$ siri-Rahimìi, MS. in ASB, leaf 467 .

2 Ibid., leaf 487.

3 Ibid., leaf 480.

4 'Abdul Bāqi proposes, in the Table of Contents of his $M a^{\prime}$ 'assiriRahìmī (MS. in ASB), to speak of 'Abdul-Rahīm Khān Khānān's Madrasahs in the third book, but, much to my disappointment, he omits the subject altogether.

${ }^{5} M a^{\prime}$ assiriri-Rahìimì, MS. in ASB, leaf 480.

${ }^{6}$ Ibid., leaves $488 \mathrm{ff}$. 


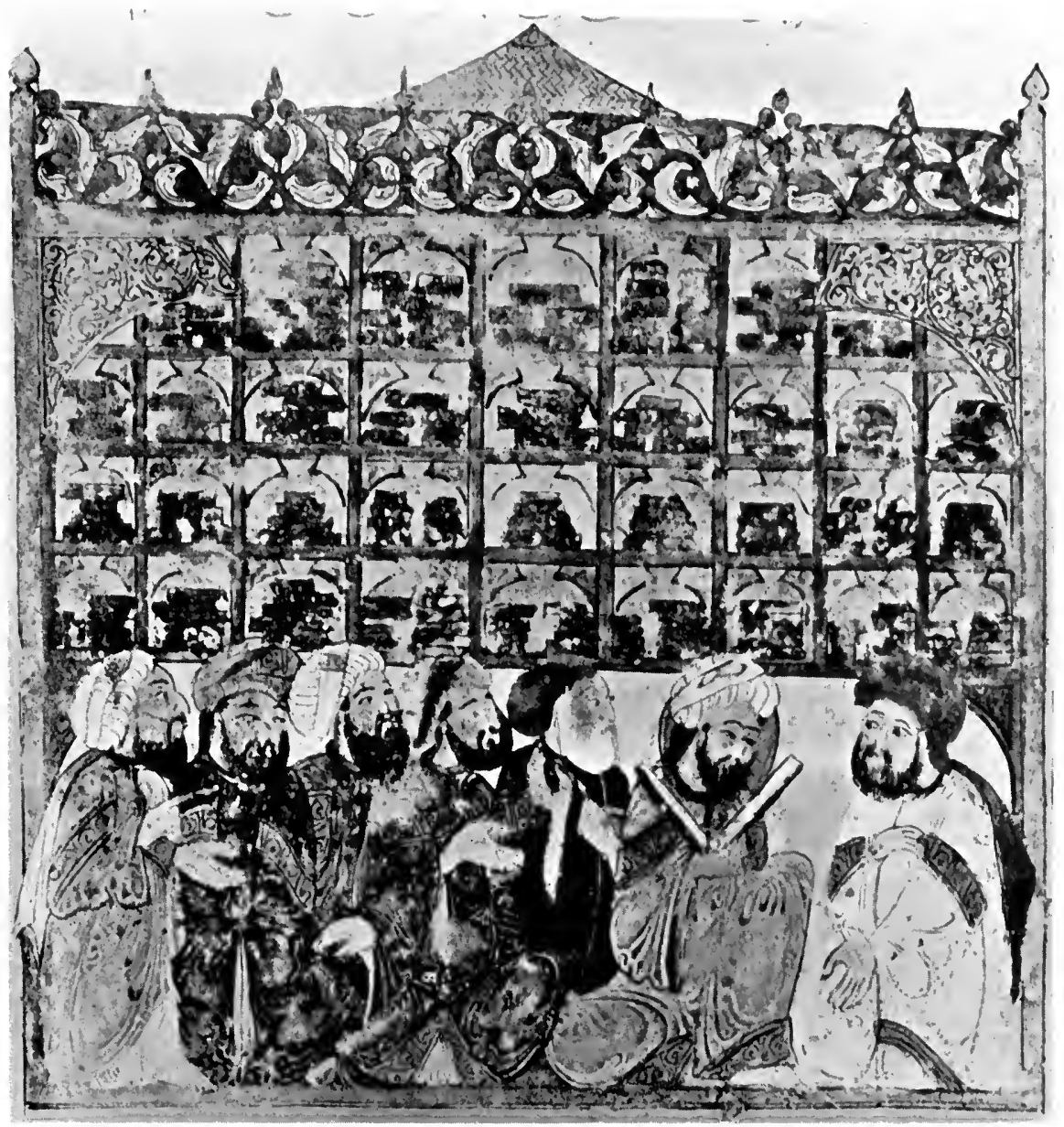

A Library at Hulwān in Persia. A person reading a book to an attentive audience. (From the "Schefer" Manuscript of Harīin, dated A.D. I 237.)

[From Martin's Miniature Painting and Painters of Persia, India and Turkey (Bernard Puaritch).]

[Facing page 170. 
$\because y^{\prime} \quad \because \cdots$

$\therefore \quad \vdots \because \vdots, \quad \vdots \quad \cdots \cdots$ 


\section{THE MUGHAL DYNASTY}

a unique position in the Indian literary world of his times. His reign is distinguished from that of other Muhammadan sovereigns who preceded or succeeded him by the broad principles of toleration and catholicity which governed every branch of his administration, political, religious, or literary. His complete identification with the interests of his subject peoples, irrespective of their faith or creed, was very well demonstrated in the entirely new attitude which he took up towards the learning and culture of the Hindus - an attitude of which the first early signs were seen in Fīrūz Shāh Tughlaq, who in some instances replaced 'Alāuddin's vandalism by the care he bestowed on such monuments of ancient civilization as the Library at Jawālāmukhì and the Asoka pillars transported from their original locations. ${ }^{1}$ Akbar's, however, was a systematic and deliberate policy of protection of Hindu learning, which showed itself, as we have already seen, in the generous provisions he made for the education of Hindu youths in their own culture in the madrasahs, along with the Muhammadan boys; in the discussions, which he initiated in the 'Ibādat Khāna with the orthodox Hindu learned men; in the translations of Hindu classics and scriptures exhibiting his profound appreciation of the value of Hindu culture as well as his zeal for its propagation; and

1 See chap. on Fìrūz Tughlaq, supra. 


\section{PROMOTION OF LEARNING}

finally, in the State patronage bestowed on distinguished Hindus for their proficiency in such fine arts as music and painting. We have also seen how Akbar was qualified to exercise his potent and beneficent influence on the literary world by his intellectual tastes (with which he must be credited to the rejection of the theory of his illiteracy) which led him to associate largely with learned men, some of whom, like Abul Faẓl, Faiz̄ī, 'Abdul Qādir and others, were even his best friends, thus establishing the difficult concord between wealth and learning. To the same intellectual tastes we also owe the debates and discussions in the 'Ibādat Khāna, which was Akbar's special innovation, and where representatives of the different religions of the land - Hindus, Buddhists, Jains, Christians and Muhammadans-met on a common platform, inaugurating a new era of religious toleration, and quickening the intellectual life of the country. Among other notable features of Akbar's reign should also be remembered the lavish patronage of learned men by stipends and rewards, the foundation of educational institutions and the creation of educational endowments, and, lastly, the abundance of literary men who were drawn to the capital by these educational facilities as also by the favourable imperial influence, so that the seats of Government became also centres of culture and enlightenment. 


\section{CHAPTER IV. \\ The Mughal Dynasty (continued). \\ I. JAHĀNGīR.}

JAHĀNGIR, though far inferior to his great father, was not without some literary taste. His education was, as we can anticipate, well cared for, but certain bad traits in his character vitiated his career. Of his preceptors, we hear of Maulānā Mīr Kalān Muhaddiṣ, who had come to Hindustan from Hirăt in the reign of $\mathrm{Akbar}^{1}$ and 'Abdul-Rahịm Mìrzā, whom we have noticed before. ${ }^{2}$ We also learn that Quṭbuddīn Muhammad Khān was appointed as his tutor (987 A.H., I579 A.D.) and a great levee was held in celebration of this event. The tutor presented the Emperor, as is customary on such occasions, with rich presents, such as elephants, etc., worthy of his post, and, taking the prince upon his shoulders, ordered dishfuls of gold and jewels to be scattered to the people. ${ }^{3}$ Over and above his knowledge of Persian, the Emperor himself tells us, he

1 Muntakhabul-Mir'ätul-'Álam, MS. in Boh. Coll., p. 29 ; Elliot viii, p. I 59.

2 Noer's Akbar, vol. ii, p. 247.

3 Muntakhhabul-Tawārīkh, vol. ii, (Lowe), p. 278. 
was not deficient in reading and writing Turkish, though he was brought up in Hindustan. Hawkins, who knew Turkish, found the Emperor well versed in that language. ${ }^{1}$ This knowledge enabled him to read the Memoirs of Bābar (Wäqia âti-Bäbari) in the original. The copy that Jahāngir possessed was written with Bābar's own hand, but four sections of it were wanting. Jahāngīr copied these portions himself and added them to the book, writing therein a few lines in Turkish to show that the addition was made by him. ${ }^{2}$ He had a taste for history and had, in common with the other Mughal Emperors, a desire to leave behind a record of the events of his reign. With this object in view, he wrote his memoirs with his own hand, but two historians had a hand in the work, viz. Muhammad Hādi and Mu'tamad Khān. When it was completed, he ordered the mutașaddis (scribes) of his library to prepare copies to be distributed among the chief government officers, and to be sent to great and influential men in all parts of the country. The first copy was presented to Shāh Jahān. ${ }^{3}$

Jahāngīr's name is associated with a regulation which he promulgated in all his dominions and by which he ordained that whenever a well-to-do man or a rich traveller died without any heir, his property

1 Elphinstone (9th ed.), p. 548.

2 Wãqi'āti-Fahāngììi, Elliot vi, p. 315.

3 Ibid., Elliot vi, p. 360. 
would escheat to the Crown and be utilized for building and repairing madrasahs, monasteries, etc. ${ }^{1}$

It is recorded in the Tärikhi-Jān-Jahän that after his accession to the throne, Jahāngir repaired even those madrasahs that had for thirty years been the druelling-places of birds and beasts, and filled them with students and professors. ${ }^{2}$

Agra, which in Akbar's time rose high as a centre of education, continued, it seems, in the same state during Jahāngīr's reign. It is thus described in the Tuzak:- "The inhabitants of Agra exert themselves greatly in the acquirement of crafts and the search after learning. Various professors of every religion and creed have taken up their abode in the city." 3

During Jahāngīr's reign, Maktūb Khān was a superintendent of the Royal Library and the Picture Gallery. ${ }^{4}$ When Jahāngīr went to Gujrāt, he took a library with him, which shows that love of books which was so marked a trait in his father's character was inherited by him. To the Shaikhs of Gujrāt, he

1 Khāfī Khān's Muntakhabul-Lubāb (Bibl. Indica), Pt. i, p. 249; Tärikhi-Akbari, MS. in A $\overline{S B}$, leaf 66.

${ }_{2} \bar{T} \bar{a} \bar{\imath} \underline{k} h i-\mathcal{F} \bar{n} n-\mathcal{F} a \bar{a} \bar{n}$ by Jān Jahān Khān, MS. in ASB. We learn that in I623 A.D. Muhammad Șafi, Diwan of the Subah of Gujrāt founded madrasahs at Fubbalpiur in front of the gate of the fort Irk, and beside Sayif Khān's madrasah (Mir'äti-Ahmadī by 'Alī Muḥammad Khān, vol. i, p. 209).

3 Tüzaki-Fahāngīin, by Rogers and Beveridge, p. 7 .

1 Ibid., p. 12. 
presented from this library such books as the TafsiriHusaini, the Tafsiri-Kashshä and the Rauzatul$A h b \bar{a} b$; and on the back of each of the books, he wrote the day of his arrival in Gujrāt and the date of presentation. ${ }^{1}$

Jahāngīr was a great lover of books. Mr. Martin says-

"Collectors (of books) complain of the exorbitant prices they are called upon to pay for Persian munuscripts, and yet the highest prices now paid are small in comparison with the sums they cost their former owners. The manuscript for which Jahāngīr paid 3000 gold rupees-a sum equivalent to $£$ to,000-would not fetch $£ 2000$ at a sale in Paris to-day. From notes and calculations I have made, miniatures by Bihzād (the famous Persian painter) were worth hundreds of pounds each, and certain of his manuscripts were then worth ten times more than now. Some decades ago, when bibliophiles still existed in the East, far higher prices were paid there than in London or Paris to-day. Through the following centuries, the same love for old books prevailed, and ridiculous prices were paid for them, as high in proportion as Americans now pay for Rembrandts and Van Dycks. The Mongols, the Timurides, the Mughals, Emperors and Amirs, all paid prices which we hardly understand, and it was not unusual for a celebrated manuscript of the $Q u r^{\prime} \bar{a} n$ to realize a sum that would be equivalent to about a million francs in modern currency." ${ }^{2}$

Jahāngīr was a lover of paintings, and gave much encouragement to painters. Farrukh Beg was the greatest painter of the time. ${ }^{3}$ Abul Hasan, a great painter of the time, presented the Emperor

1 Tüzaki-Fahāngīì̄, by Rogers and Beveridge, pp. 439, 440.

2 Martin's Miniature Painting and Painters of Persia, India and Turkey. vol. i, p. 58.

3 Tüzaki-Fahāngìri, by Rogers and Beveridge, p. 159. 
with a picture of his Court, which he used as frontispiece to his Fahāngìr-Nämah. Hasan was also a good hand at drawing portraits. Manșūr was another great painter, who was invested with the title of Nädir-ul-Asr. ${ }^{1}$

Painting in Jahāngīr's reign reached a great excellence. Says Catrou: "In this time, there were found in the Indies native painters who copied the finest of our European pictures with a fidelity that might vie with the originals." 2

Sir Thomas Roe, during his stay in Jahāngīr's Court, presented the king with a picture. Jahāngìr's chief painter, who was sent for to see it, said that he could paint like it. After some time, the Emperor showed Sir Thomas six pictures, five of which were painted by his own painter. They were so very similar that by candle-light one could not be distinguished from the other. It was only after a close and minute scrutiny that Roe could make out the picture presented by himself. The ambassador says that he did not expect that the painter could perform so well. ${ }^{3}$

1 Wāqi'āti-Fahāngīrī, Elliot vi, p. 359. "Jahāngīr was a great lover of birds, and had a painter Manșūr who portrayed his favourites (birds) in a way often worthy of Dürer."-Martin's Miniature Painting and Painters of Persia, India and Turkey, vol. i, p. 88.

For an account of the painters of Jahängīr and their paintings existing in the British Museum and other places, see ibid., pp. I 3 I, I32.

2 Catrou's History of the Mughal Dynasty, p. I78.

3 Purchas His Pilgrims, vol. iv, pp. 344 ff. 
Jahāngìr employed painters to illustrate his Fahangir-Namah with pictures of the animals that were brought to him from the seaport of Goa by Muqarrab Khān, with the object that their "actual likeness might afford a greater surprise to the reader than mere description." 1

The Iqbäl-Nämah mentions the following singers of Jahāngīr's Court: Jahāngīrdād, Chatar Khān, Parwīzdād, Khurramdād, Makhū and Hamzah.

Among the learned men of his Court may be mentioned Mĩrā Ghiyāṣ Beg, unrivalled in elegant composition and arithmetic. ${ }^{2}$ Naqỉb Khān was noted for his knowledge of history-a subject on which he wrote much. Mu'tamad Khān, whom we have noticed above, and Ni'matullah were Jahāngīr's historiographers. ${ }^{3}$ Under Jahāngīr's patronage, Ni'matullah systematized into a book the materials collected by Haibat Khān of Sāmāna regarding the history of the Afghāns. ${ }^{4}$ 'Abdul Haqq Dihlawi, one of the most learned men of the time, came to wait upon Jahāngīr and presented him with a book upon the lives of the Shaikhs of India. ${ }^{5}$

1 Wāqi'āti-Fahāngīrī, Elliot vi, p. 331 .

2 Price's Fahāngìr, p. 26.

${ }^{3}$ Elliot v, p. 67, and vi, p. 28o. For Naqib, see B. p. 449.

4 See Dorn's Preface to Makhzani-Afghāni.

5 Wāqiāti-Fahāngìì, Elliot vi, p. 366. 


\section{THE MUGHAL DYNASTY}

Jahāngìr tells us in the Tüzak that on Friday evenings he used to associate with learned men, darwishes and recluses. ${ }^{1}$

The Iqbāl-Nàmah-i-Zahāngìri gives us a list of some learned men and poets contemporary with the sovereign.

The learned men were-

(I) Mullā Rūzbahān Shirāzī,

(2) ", Shukarullāh Shirāzī,

(3) „ Tuqyai Shūstarī,

(4) Mīr Abul Qāsim Gīlānī,

(5) A'mī A'marì,

(6) Mullā Baqar Kashmīini,

(7) , , "Tuhta'ì,

(8) ", Maqșūd 'Alī,

(9) Qàzị Nūrullāh,

(Io) Mullā Fāzil Kābulī,

(I I) ", 'Abdul Ḥakīm Siyālkūṭī,

(12) " , Muțțālib Sulțānpūrī,

(13) " , Raḥmān Bhurah Gujrātī,

(I4) " Hasan Farāghī Gujrātī,

(I5) , Husain Gujrātī,

(I6) Khwājah 'Ușmān Hiṣārī,

(I 7) Mullā Muḥammad Jaunpūrī. ${ }^{2}$

Of the poets the work mentions-

(I) Bābā Ṭālib Ișpahānī,

(2) Mullā Hayātī Gīlānī,

1 Tüzaki-Fahāngīri, by Rogers and Beveridge, p. 2 I.

2 Iqbāl-Nämah-i-Fahāngìrì (Bibl. Indica), p. 308. 
Chapter

Shäh Jahān and Dārā

Shikūh.

\section{PROMOTION OF LEARNING}

(3) Mullā Naẓîrī Nishāpūrī,

(4) „ Muḥammad Șūfî Māzandrānī,

(5) Malik-ul- Shu'arā Ṭālibaī Āmlī,

(6) Sa'īdāi Gìlānī,

(7) Mìr Ma'șūm Kāshī,

(8) Fasūnī Kāshīī,

(9) Mullā Haidar Khașālī, and

(Io) Sha'īdā. ${ }^{1}$

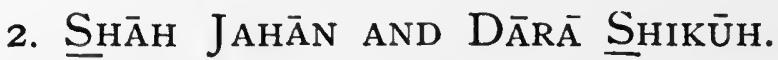

Though Shāh Jahān is better known for his magnificence,-for the superb structures with which he beautified his Shāh-Jahānābād or set up as memorials to his dear and near relations,- than for his zeal for the promotion of education or for extending the bounds of learning of himself and his subjects, yet it appears that he did nothing to undo the educational works of his father and grandfather; on the other hand, there is evidence to show, as the Tafrihul-'Imārät ${ }^{2}$ states, that he followed in Akbar's footsteps.

The renowned traveller Bernier, who visited India about this time, draws a melancholy picture of the state of education in Hindustan, which seems to be a little overdone. He says-

"A gross and profound ignorance reigns in those states. For how is it possible there should be academies and colleges well

1 Iqbāl-Nämah (Bibl. Indica), p. 308.

2 Tafrị̀ul'Imārāt, by Sīlchānd, MS. in ASB, leaf $4 \mathrm{I}$.

180 


\section{THE MUGHAL DYNASTY}

founded? Where are such founders to be met with? And if there were any, whence were the scholars to be had? Where are those that have means sufficient to maintain their children in colleges ? And if there were, who would appear to be so rich? And if they would, where are those benefices, preferments and dignities that require knowledge and abilities, and that may animate young men to study?" 1

Though Shāh Jahān's reign may not be distinguished for any special educational progress, yet Bernier's statement does not seem to express the real state of things. That he was by no means a reactionary is proved by the fact that all the educational institutions, with their rich endowments made by the previous Emperors, nobles and private gentlemen, continued in unabated prosperity in his time. On the other hand, to Shāh Jahān is traced a distinct and important contribution to educational works, viz. the foundation of an Imperial College at Delhi in the vicinity of the famous Jāmi' Masjid. As recorded by Carr Stephen-

"To the north of the Jāmi' Masjid (of Delhi) was the Imperial Dispensary, and to the south was the Imperial College; both these buildings fell into ruin long before the rebellion of 1857 , and were levelled with the ground soon after that event. They were built with the mosque in 1060 A.H. (1650 A.D.)." ${ }^{2}$

Sayyid Ahmad further adds that Maulawī Muhạmmad Sadruddīn Khān Bahādur, Șadr-ul-Șudūr of Shāh-Jahānābād, had the madrasah transferred to him later on from the then reigning Delhi

1 Bernier, p. 210 (Ouldinburgh's edition).

2 C. Stephen's Archaeology of Delhi, p. 255.

I8I 
Emperor, repaired and made additions to the building, and by his energy put new life into it. ${ }^{1}$ Shāh Jahān repaired the college named Dār-ulBaqā (Abode of Eternity), which had been entirely ruined. The Emperor repaired the buildings and appointed a few distinguished learned men as professors of the college. Maulānā Muḥammad Șadruddin Khān Bahādur, the chief justice of Delhi, was nominated by the monarch as the director of the institution with a view to make it flourishing. Near it were two large reservoirs, a mosque, a hospital and a big bazar. ${ }^{2}$

It appears from Shāh Jahān's routine of daily work that some time was set apart at night for studies.

"At about 8.30 p.m. he retired to harem. Two and sometimes three hours were here spent in listening to songs by women. Then His Majesty retired to bed and was read to sleep. Good readers sat behind a pardah which separated them from the royal bedchamber, and read aloud books on travel, lives of saints and prophets and histories of former kings-all rich in instruction. Among them, the Life of Timür and the Autobiography of Bābar ${ }^{3}$ were his special favourites." 4

$1 \bar{A}$ särul-Sanādìd, by Sayyid Ahmmad, 3rd chap., p. 69.

2 Garcin de Tassy's transl. of Sayyid Ahmad, p. I52, corresponding to $\bar{A}$ särul-Șanädìd, 3rd chap., p. 69.

3 It appears from Shäh-Fahān-Nämah, by Muhammad Amin-iQazwīni (MS. in ASB, leaf 34), that a copy of the Memoirs in Bābar's handwriting was in Shhāh Jahān's Library.

4 J. Sarkar's Anecdotes of Aurangzib and Historical Essays, p. I74. 


\section{THE MUGHAL DYNASTY}

Shāh Jahān was a great patron of music, and, it seems, could himself sing well. ${ }^{1}$ His two great singers were Rām Dās and Mahāpāttar. ${ }^{2}$

Shāh Jahān encouraged painting also. Muhammad Nādir Samarqandi was one of the best painters at his Court. ${ }^{3}$ The Shāh Jahānī style of painting is almost the same as the Jahängīin, though, of course, both of them are different from the Akbarī style. ${ }^{4}$

The name of Shāh Jahān will always be associated with the well-known historical work $P \bar{a} d s h \bar{a} h$ Nämah, which was written by Muhammad Amīn-iQazwīin, by the Emperor's order. ${ }^{5}$

Shāh Jahān encouraged learned men by rewards. and stipends. ${ }^{6}$ Some of the learned men and poets of his reign were-

(I) Sayyid Bukhārī Gujrātī,

(2) , Jamāluddīn,

1 Mir'ātul-'Alam, MS. in Boh. Coll., leaf 181 ; also J. Sarkar's Anecdotes of Aurangzib and Historical Essays, pp. 173, I74.

2 Willard's Treatise on Hindu Music, p. 2 I 3.

3 See Martin's Miniature Painting and Painters, etc., vol. i, p. 132. For an account of the paintings executed by the painters of Shāh Jahān's Court, see pp. I3I, I 32 (ibid.).

${ }^{4}$ Ibid., p. 82.

5 Elliot vii, p. I.

6 For an account regarding this point, see $B \bar{a} d \underline{s h} \bar{a} h-N a \bar{m} a h$, by 'Abdul Hamīd Lāhaurī, vol. i, pp. 106, 3 18, 364, and vol. ii, pp. 127, I 38, I 84 and 309 ; also Mir'âtul-'Álam, MS. in Boh. Coll., leaf 190. 'Abdul Hakīm Siyālkūṭī was on one occasion given his weight in silver. 


\section{PROMOTION OF LEARNING}

Shikūh.

(3) Shaikh Mìr Lāhuarī,

(4) Khwājah Khwānd Maḥmūd, daughter's son of 'Alāuddin Attar,

(5) Shaikh Bahlūl Qādirī,

(6) Mĩrzā Ziyāuddīn,

(7) Maulānā Muhib’ali Sayyidī,

(8) Shaikh Nàzīini,

(9) Mullā Shukullāh Shīrāzī,

(Io) Mīr 'Abdul Qāsim İrānī,

(I I) Mullā Muḥammad Fāẓil Badakhsh shīi, etc., etc.

The royal family got a scholar in Prince Dārā, who mastered both Arabic and Persian and was proficient in Sanskrit, translating into Persian some of the best Sanskrit works. One of his tutors was Shaikh Hirwī of Khurāsān, a pupil of Maulānā 'Abdul Salīm, a very learned man. ${ }^{2}$ Prince Dārā, in his later days, showed great leanings for the religion and institutions of the Hindus, was constantly seen in the company of Brāhmanas, Jogīs and Sannyāsīs, and had great respect for Hindu learning. The Vedas inspired him with reverence; and he collected learned Hindus from all parts of the country to translate them. The religious love of the Hindus made a deep impression upon him; he imbibed its doctrines, and

1 Shäh-Fahān-Nāmah, MS. in ASB, leaves $574 \mathrm{ff}$.

2 Elliot viii, p. I59 (from Fāmi'-Fahān-Nüma of Muzaffar Husain). 
engraved in Hindi letters the word Prabhu upon his rings of diamond, ruby, etc. ${ }^{1}$

$\mathrm{He}$ was a voluminous writer, being the author of the following books :-

(i) Sirr-ul-Asrär (Secret of Secrets). It is sometimes called Sirr-ul-Akbar, "The Great Secret." It is a Persian translation of the Upanishads. During his stay in Kashmir, as we learn from the preface to his work, the Prince became a disciple of a great Șūfī, Mullā Shāh. He read a number of standard works on Șúfiism, but found that pantheism was nowhere more satisfactorily taught than in the Vedas, and especially in the Upanishads. So he summoned a few Pandits from Benares, which was now under his administration, and with their help went on with the work. It was finished in I657 A.D. ${ }^{2}$

(ii) A translation of the Bhägavadgitta.

(iii) A translation of the Jog-Väsishtha Rämayana. There are two other translations of this work, one by an unknown author and the other by some learned Hindus at the instance of Akbar the Great. Faizi had a hand in the latter work.

(iv) The Mukälamah-i-Bäba Làl Dās - an account of the dialogue between the Prince and

1 'Ālamgīr-Nāmah, Elliot vii, p. I79.

2 It was rendered into Latin by Anquetil-Duperron, and published by him at Paris in I80I. (See Constable's Bernier, p. 323 n.) 


\section{PROMOTION OF LEARNING}

Jahān

Bābā Lāl Dās on the life and doctrines of Hindu ascetics.

(v) Safinat-ul-Auliyā-Biographies of Saints from the beginning of Islām to the author's time (completed in I640 A.D.).

(vi) The Sakinat-ul-Auliya - a notice of an Indian saint, Miyān Mīr, and his disciples (completed in 1642 A.D.).

(vii) The Nädir-ul-Nukāt,

(viii) The Hasanat-ul-'Arifin,

(ix) The Risälah-i-Haqnumā

works on

Șūfîism ;

(x) The Majma'-ul-Bahrain-a treatise ${ }^{1}$ on the technical terms of Hindu Pantheism and their equivalents in Sūfī phraseology. It was written to reconcile the two systems (completed in I654 A.D.).

Had Dārā Shikūh been successful in counteracting the machinations of Aurangzib, the character of the education of the people would have received a different form. Lieut.-Col. Sleeman, who visited the grave of this Prince, deplores-

" Here, under a marble slab, lies the head of poor Dārā Shikūh, who, but for a little infirmity of temper had, perhaps, changed the destinies of India, by changing the character of education. While looking upon the slab under which his head reposes, I thought of the slight accidents by flood and field, the still slighter thought of the brain and feeling of the heart on which the destinies of nations and of empires often depend." 2

${ }^{1}$ For some of my information regarding Dārā Shikūh, I am indebted to Prof. Hidāyat Husain.

${ }^{2}$ Sleeman's Rambles and Recollections, vol. ii, pp. 270, $27 \mathrm{I}$. 


\section{THE MUGHAL DYNASTY}

\section{Aurangzib.}

The next reign we have to consider is that of Aurangzib, the last of the great Mughals, whose educational policy took after that of his general policy in governing the empire in the interests of his co-religionists, to which the interests of the subject people of other faiths were carefully and deliberately subordinated. Unlike Akbar, he cared very little for the promotion of Hindu learning. In April, 1669, for instance, he ordered the provincial governors to destroy the Hindu schools and temples and to put down their teachings and religious practices. ${ }^{1} \mathrm{He}$, however, tried earnestly to foster the education of Muhammadan youths and diffuse Muslim learning in his dominions. He appointed professors in the different parts of his empire for educating Muslim youths. Stipends were also given to students in proportion to their progress in education. ${ }^{2}$

Mr. Keene, in his Mughal Empire, thus sums up his educational works along with his other good deeds: "Aurangzib abolished capital punishment, encouraged agriculture, founded numberless colleges and schools, and systematically constructed roads

1 J. Sarkar's Anecdotes of Aurangzib and Historical Essays, p. I I.

2 Mir'ätul-'Alam, by Bakhtāwar Khān, MS. in the Boh. Coll., leaf 257 ; 'Alamgìr-Nämah, by Maulawī Munshī Muhammad Kāzim (Bibl. Indica), p. 1085; Ma'áșiri-'Álamgìrī, by Muhammad Säqī Musta'id Khān (Bibl. Indica), p. 529 ; Tabșiratul-Näzirīn, MS. in ASB, p. 158. 


\section{PROMOTION OF LEARNING}

and bridges." 1 Of these educational institutions, very few are known at this distant date, but there is evidence to show that he once confiscated the buildings belonging to the Dutch in Firinghi Mahal (Franks' quarter), a ward of the city of Lucknow, and made them over to a Musalman for a madrasah. ${ }^{2}$ He sent orders to Makramat Khān, Diwan of Gujrāt, as he did to other Diwans in his dominions, that all students from the lowest to the highest form, those who read the Mizann as well as those who read the Kashshäf, be given pecuniary help from the State Treasury with the sanction of the professors of colleges and of the Sadr of the place. Orders were also sent that three professors in Aḥmadābād, Pațan and Surat, and forty-five students in Aḥmadābād, be added to the existing number. ${ }^{3}$ In 1678 he sanctioned a sum of money to repair madrasahs in Gujrāt. ${ }^{4}$ It also appears that Akramuddin Khān Șadr built a college in A.D. 1697 in Aḥmadābād, at an expense of Rs. I 24,000, and asked Aurangzib for pecuniary help. In response, the Emperor gave as jagirs village

1 Keene's Mughal Empire, p. 23.

2 Constable's Bernier, p. 292 n.

3 Mir'āti-Ahınadī, by Alī Muhammad Khān, vol. i, p. 272. "Aurangzib assisted students, in proportion to their proficiency, with daily stipends, viz. students of Mizzann received I anna, of Munsha'ib 2 annas, and up to Sharhi-Wiqãyah and Figh 8 annas per diem."-Tärikhi-Farh-Bakhsh of Muhammad Faiz Bakhsh, translated by W. Hoey, p. 104

4 Mir'äti-Aḥmadì, p. 309. 
II.]

\section{THE MUGHAL DYNASTY}

Sūndra (in Pergana Sānoly) and village Sīha (in Pergana Karīi). ${ }^{1}$

Aurangzib took steps to educate the Bohras of Gujrāt by appointing teachers for them and by monthly examinations, the results of which were reported to the Emperor. As a penalty, however, for the troublesome conduct of some of them, the Emperor ordered that the expense of their education, which was made compulsory, should be borne by the community. ${ }^{2}$ Besides the college of Akramuddīn Khān Sadr, there were other madrasahs established by private individuals. Qāẓi Rafi'uddīn Muhammad founded a college in Biānāh close to Qāzịun-ki-Masjid. It bears an inscription dated IO80 A.H. (I670 A.D.). ${ }^{3}$

During Aurangzib's reign Siyālkūt was a great seat of Muslim learning. Learned men from various parts of the country resorted to this place. Maulawī 'Abdullāh taught in a school in this town set up by his father Maulawi Abul Hakìm who was himself an eminent teacher. It should be observed here that the reputation of Siyālkūt as a place of learning dates back to the time of Akbar. ${ }^{4}$ It was perhaps due to the fact that it was a seat of

1 Mir'äti-Aḥmadī, by 'Alī Muhammad Khān, vol. i, p. 363, and vol. ii, p. 37 .

2 Ibid., vol. i, pp. $377,378$.

3 Archaeological Survey Report, vol. xx, pp. 76, 77.

4 Khulāsatul-Tawārikkh, MS. in ASB, leaf 47; see also J. Sarkar's Topography of the Mughal Empire, p. 96. 


\section{PROMOTION OF LEARNING}

learning where papers were extensively used that Siyālkūt also became distinguished for that commodity, especially the Mānsinghi and the silk paper which were good in texture, clean and durable. They were manufactured in three hamlets forming suburbs of the city, exported to other parts of the country and largely used in the courts of the Delhi Emperors. ${ }^{1}$

We have already seen that almost all the Mughal Emperors took much interest in the education of the people and the diffusion of learning. This was no doubt due to the love of learning which was infused into them by their education received by them from an early age. It was generally the practice, according to Niccolao Manucci, that when the princes attained the age of five, they were taught to read and write their mother-tongue, which was Tartar, or the old language of the Turks. Afterwards, they were placed under learned men and eunuchs to teach them the liberal and the military arts. The teachers took care to regulate their amusements in such a way as would afford them facility in acquiring knowledge of the world and lead to refined habit and taste. ${ }^{2}$ Like other princes Aurangzib

1 J. Sarkar's Topography of the Mughal Empire, p. 95, and Imp. Gazetteer, xii. As Siyālkūt (Sealkot) was famous for paper manufacture, so was Kashmir for its ink (ibid., p. I12).

2 Storia do Mogor, by Niccolao Manucci, vol. ii, pp. 346, 347. 
received his education at an early age. His first teacher was Sa'dullah Khān, who afterwards became one of the ministers of Shāh Jahān. Another teacher of his was Mir Muhammad Hashim. The Prince had a keen intelligence and learnt quickly what he read. He got by heart the Qur'an and the Hadis, could read and write Arabic and Persian with great facility, and had a mastery over Chāghtā' 1 Turki , the language of his remote ancestors. He had a proclivity for theological works, such as the commentaries on the Qur'än, the Hadiss, Islāmic Law, Imām Muḥammad Ghazzālī's works, etc. This early taste for theological writings made him an orthodox of the orthodox Muhammadans and gave him a Puritanic taste, which made him despise painting, music, ${ }^{1}$ and poetry in general except that which contained a moral, ${ }^{2}$ which also accounts for his hatred for everything Non-Islāmic in character. Aurangzib, however, was not satisfied with the

1 Storia do Mogor, by Niccolao Manucci, vol. ii, pp. 346, 347 . Aurangzib's excessive orthodoxy caused him to suppress music. Thus the profession of the musicians was almost gone. It is said that about a hundred of them consulted together and brought out twenty biers with loud cries and lamentations, in order to excite the pity of the Emperor on their condition, while he was on his way to the mosque. On Aurangzib's inquiry, he was told that the musicians were going to bury Music, who was killed by his order. The Emperor calmly remarked that they should pray for her soul and see that she was well buried.-Manucci's Storia do Mogor, vol. ii, p. 8.

${ }^{2}$ J. Sarkar's Hist. of Aurangzib, vol. i, pp. 4 ff. ; Lanepoole's Aurangzib, p. 27. 
instruction that had been imparted to him by his teacher, ${ }^{1}$ whom he gave that celebrated rebuke recorded by Bernier, which embodies in itself his views upon the education which a Prince of the Royal House ought to receive :

"Was it not incumbent upon my preceptor," he said, " to make me acquainted with the distinguishing features of every nation of the earth ; its resources and strength, its mode of warfare, its manners, religions, form of government, and wherein its interests principally consist, and by a regular course of historical reading, to render me familiar with the origin of states, their progress and decline, the events, accidents or errors, owing to which such great changes and mighty revolutions have been effected ?" 2

Aurangzib, like his father Shāh Jahān, made a division of his time from a sense of duty. He used to read the Qur'a $n$ in the morning between 5 and 7 , and in the afternoon between 2.30 and 5.30 he used to read and copy the Qur'an and study the works of the pious men of Isläm. He devoted the whole evening of every Thursday to reading sacred books and to prayer. $^{3}$ From his last will, it appears that he used to sell the copies of the Qur'an transcribed by himself for his personal expenses, and that at

1 Both Bernier and Manucci give the name of this teacher as Mullā Șālih (Bernier's Travels, Constable's ed., p. I 54 ; Manucci's Storia do Mogor, vol. ii, p. 30) ; but Prof. J. Sarkar denies that Mullā Șālih was the teacher of Aurangzib (Hist. of Aurangzib, vol. i, p. 4).

2 Bernier's Travels, p. I 56.

3 J. Sarkar's Anecdotes of Aurangzib and Historical Essays, p. 177 . 


\section{THE MUGHAL DYNASTY}

the time of his death, there was a balance of Rs. 305 in his purse. ${ }^{1}$ It is recorded in the Mir'atul'Alam that 'Allamgīr studied with Muhammad Qanauji three days in the week the Ihyä-ul-'Ulüm and other books. ${ }^{2}$ The Emperor, as we have stated, was fond of reading Islämic laws, and collected the eminent jurists of his kingdom and caused them to compile the Fatäwa-i-'Alamgiri $\bar{i}$ under the supervision of Mullā Nizạam, spending a considerable amount for the purpose. ${ }^{3}$

Aurangzib's love of theology led him to collect Tafsirss, works on Hadiss, Fiqh, etc. The collection in the Imperial Library was thus augmented. ${ }^{4}$

1 J. Sarkar's Anecdotes of Aurangzib and Historical Essays, p. 52; Asiatic Annual Register, vol. iii, p. 94.

2 Muntakhabul-Mir'ätul.'A Alam, MS. in Boh. Coll., p. 3.

${ }^{3} M a^{\prime} a$ siri-'Alamgìì (Bibl. Indica), p. 530.

${ }^{4}$ Mir'ätul-'Alam, MS. in Boh. Coll., leaf 258. 


\section{CHAPTER V.}

The Mughal Dynasty (continued).

I. BAHĀDUR ShĀH (I707-I7I2).

THE glory of the Muhammadan rule began to decline with the death of Aurangzib. Works of public utility of Emperors and private individuals became few and fewer since Bahãdur Shāh came to the throne. He was well-educated and fond of the society of learned men $;{ }^{1}$ yet during his reign we have two instances of colleges being established in Delhi. The first was the college founded by Ghāzīuddinn, and the second by Khān Fīrūz Jang who was buried in his own madrasah in II2O A.H. (I7 I I A.D.). ${ }^{2}$ Ghāziuddinn, the father of Așaf Jāh the founder of the Nizanam Dynasty in the Deccan, was a favourite officer of Aurangzib and was one of the principal Amīrs in the court of Bahādur Shāh. Near the Ajmere Gate of Delhi, he constructed a college and also his own mausoleum and a mosque -all situated within the same enclosure. These

1 Zubdatul-Tawārikh, by 'Abdul Karìm, p. 70.

2 Mir'äti-Aḥmadì, vol. i, p. 410. 


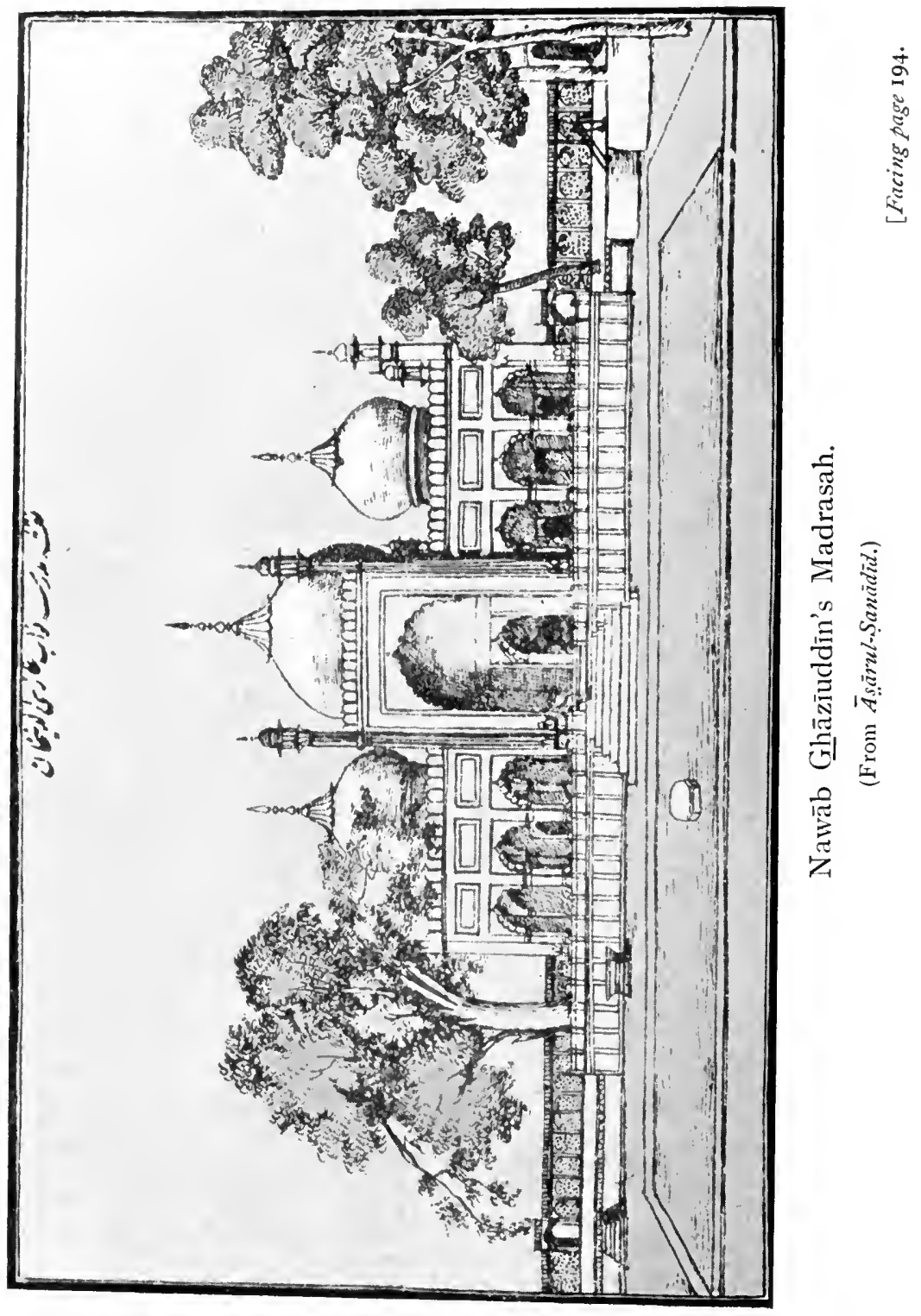


$\therefore \quad \because$ 


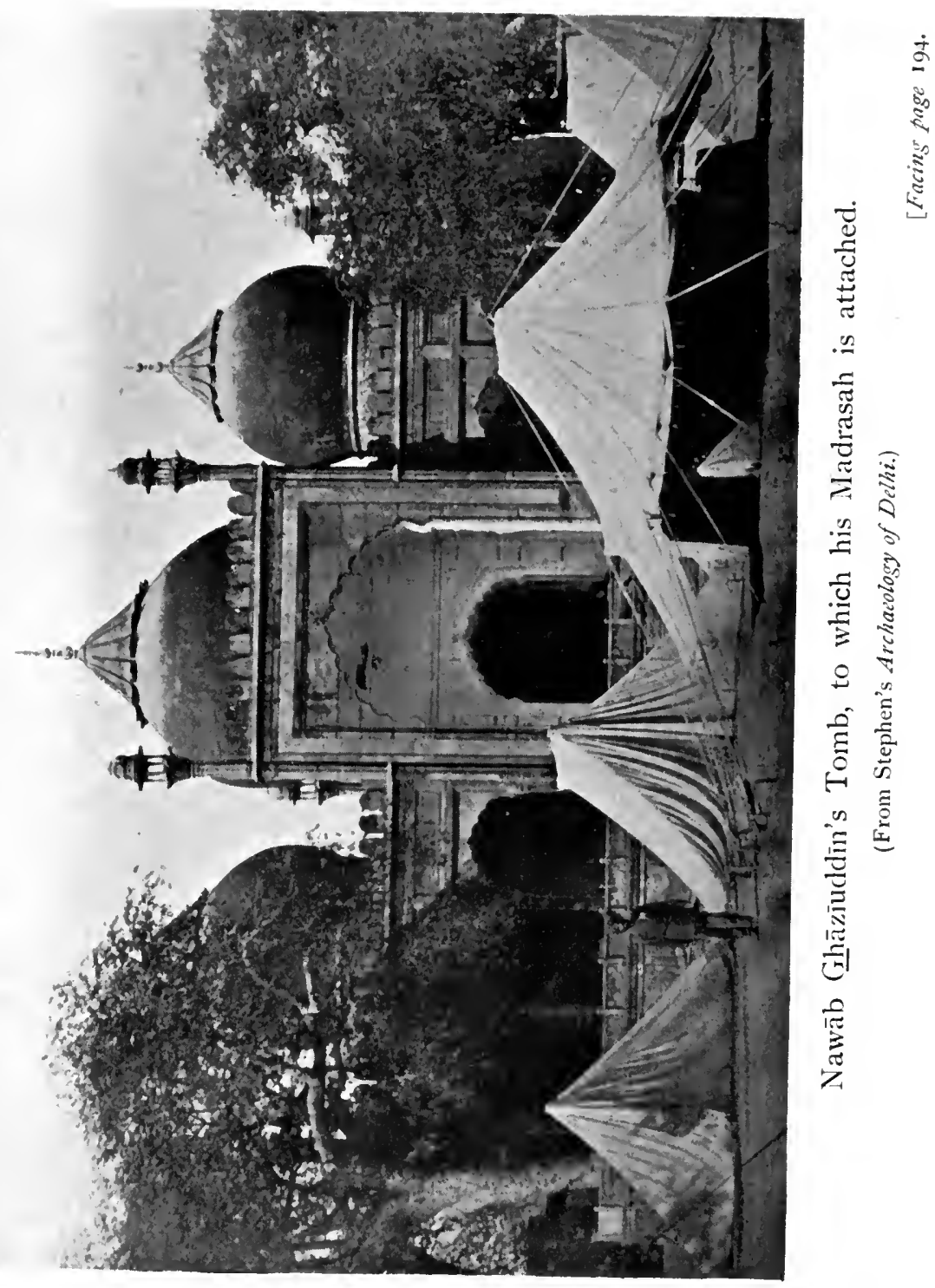


1.

$\because \cdots$ 
superb structures were originally outside ShāhJahãnābād, but were included within the modern Delhi when the walls were repaired by the British Government in 1803 . A handsome gateway leads into the enclosure. There are arched rooms in the outer wall of the gateway which are supposed to have been the kitchen of the students of the madrasah. The college was closed in 1793 for want of funds. ${ }^{1}$ The college, the mausoleum and the mosque of Ghāziuddin within the same enclosure form one of the few remaining specimens of religious endowment similar to those of the middle ages in Europe, combining in one spot a place of worship, a tomb of the founder, and a residence and place of instruction for those who were to have charge of them,- - all built during his lifetime. ${ }^{2}$ The college is now uninhabited. ${ }^{3}$

During the reign of this monarch, another college existed at Qanauj. This madrasah was called Fakhrul-Marābi'. Maulawī 'Ālimuddīn and Maulawī Na'īmuddīn completed their education in this institution. ${ }^{4}$ This madrasah should not be confounded with the one of almost the same name, viz. Fakhrul-Marābi' Rub'ul Mafākhir, which was

${ }^{1}$ Stephen's Archaeology of Delhi, p. 264; Hearn's Seven Cities of Delhi, p. 44 ; Francklin's Shāh 'Álam, p. 200.

${ }^{2}$ Fanshawe's Delhi Past and Present, p. 64.

3 Francklin's $\underline{S h} \bar{a} h$ 'Alam, p. 200.

$4 T \bar{a} r \bar{k} k h i-F a r r u k h a \bar{a} b \bar{a} d \bar{z}$, MS. in ASB, leaf 227. 
founded afterwards in Farrukhābād by Muhammad Wali-ullāh, the author of the Tärikhi-Farrukhāāädi. ${ }^{1}$

\section{Mup̣ammad ShāH (I719-I748).}

Notwithstanding the confusion that followed in the administration of the country since the accession of Muhammad Shāh to the throne of Delhi created by the conduct of the two Sayyid brothers and the subsequent invasion of Nādir Shāh, there was yet a brilliant feature upon which the mind delights to dwell, namely the impetus that was given to scientific education, especially to its astronomical branch by the genius of Sewai Jai Singh, Rājā of Amber and founder of the principality of Jaipur. He constructed observatories not only in Jaipur, Ujjain, Mathurā and Benares, but also in Delhi. His observatory in the capital of the Mughal empire was built in 1724, in the fifth year of the reign of Muhammad Shāh, at the instance of the Emperor. This monument of his genius still exists outside the walls of Delhi. Though it was never completed, and was badly damaged by the Jāt marauders within fifty years of its erection, yet it had sufficiently advanced to fulfil the purpose for which it was constructed. ${ }^{2}$ From

1 Tärikhhi-Farrukhābōà, MS. in ASB, leaf 295.

${ }^{2}$ Stephen's Arch. of Delhi, p. 269; Fanshawe's Delhi Past and Present, p. 247. 


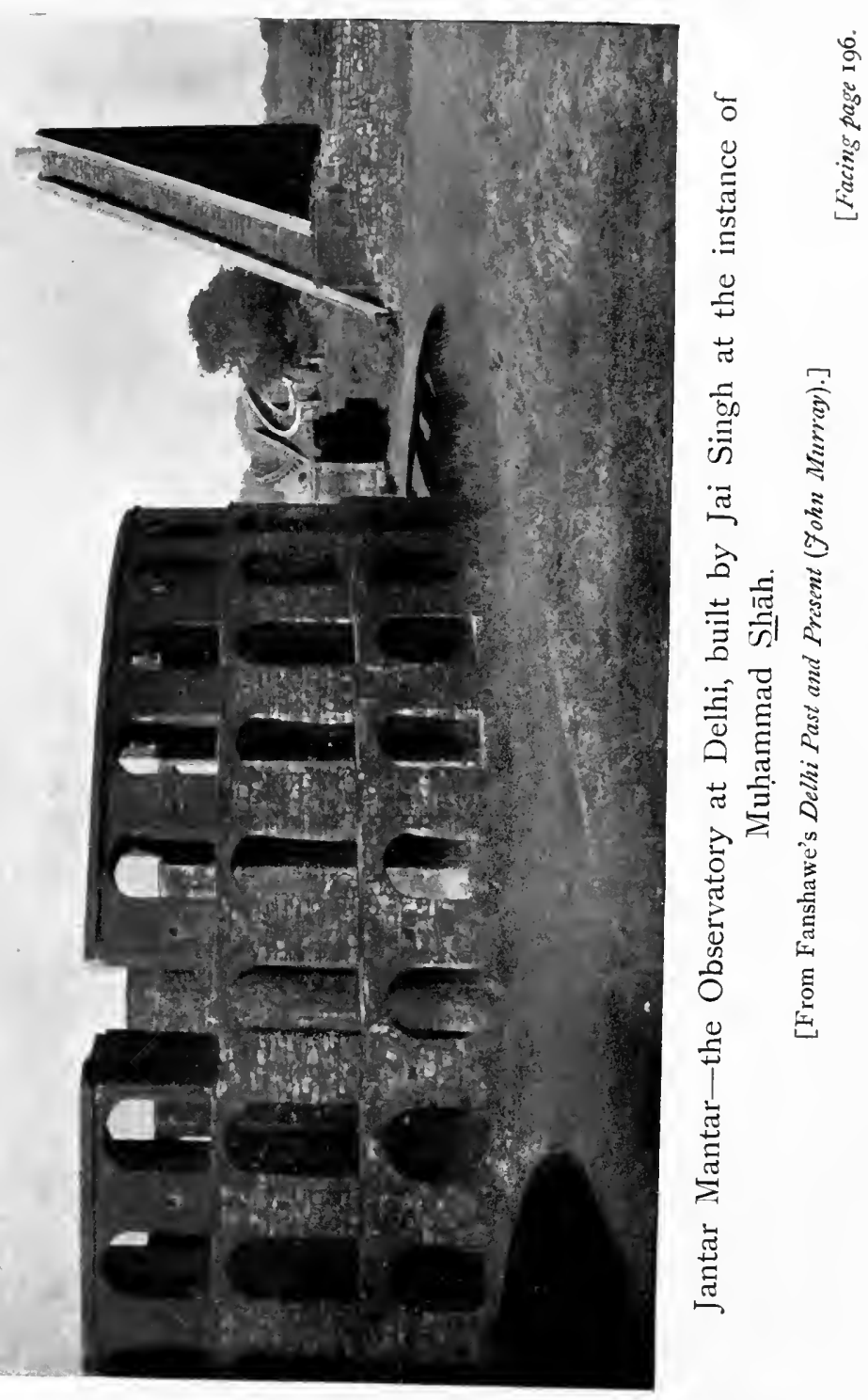


○.

a 


$$
\begin{aligned}
& 1 \\
& 3 \\
& 3
\end{aligned}
$$




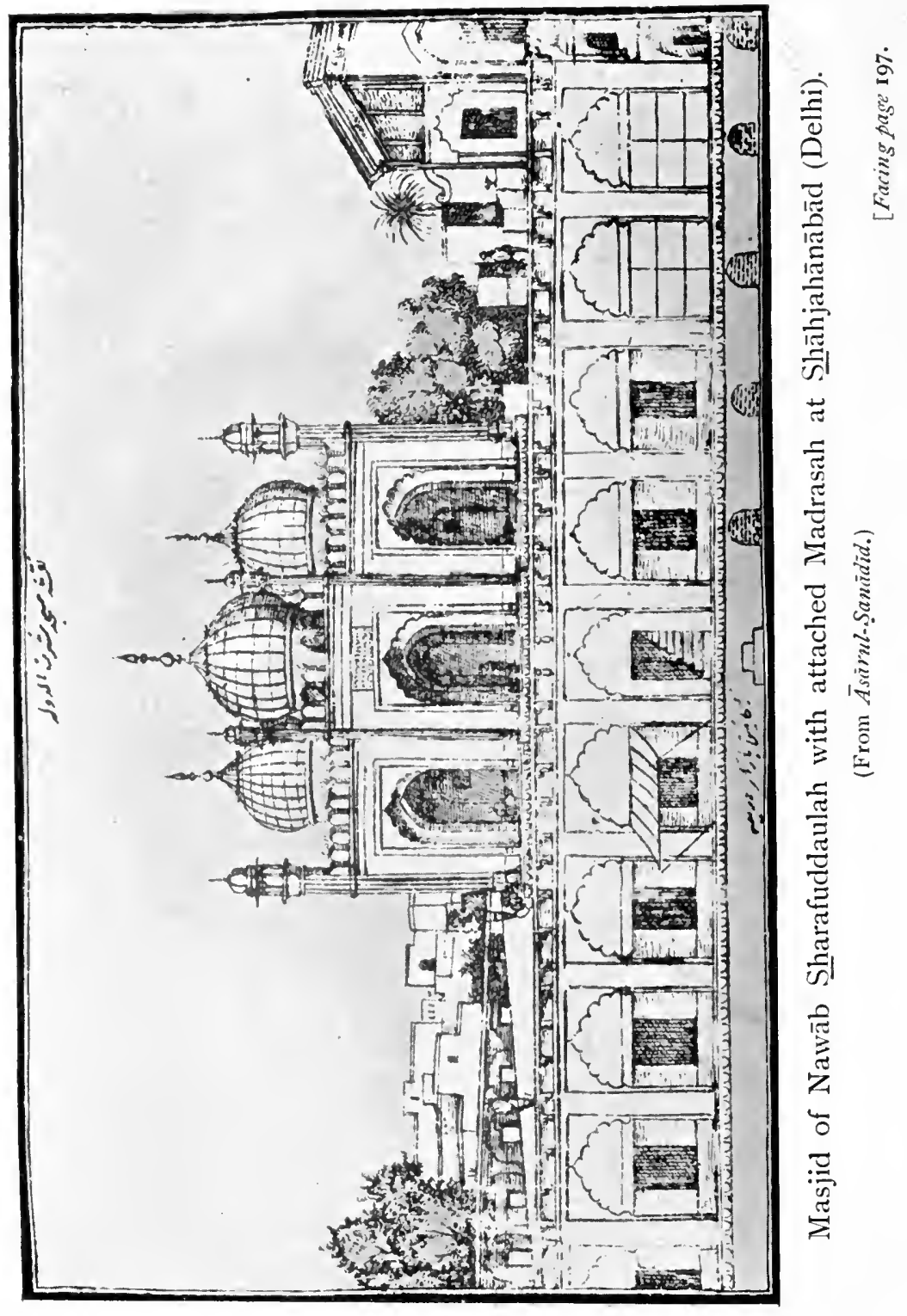




\section{THE MUGHAL DYNASTY}

the observations made in this observatory, the celebrated Astronomical Tables, known by the name of Muhammad Shāhī, were drawn up by Mīrzā Khairullāh and Shaikh Muhammad Muhaddiș, under the supervision of Jai Singh, and the accuracy of the Tables was proved by the conjunction of two planets in I I54 A.H. (I74I A.D.) as recorded therein. ${ }^{1}$ In the observatory at Delhi there is a big equatorial dial which for its accuracy and magnitude was called Samrāt Jantra by Jai Singh himself. The gnomons and the periphery of the circle are marked with degrees for determining altitudes and azimuths of the heavenly bodies. Besides this, there are two circular buildings open at the top and a small altitude-meter. ${ }^{2}$

In 1722, during the reign of Emperor Muhammad Shāh, Nawāb Sharafuddaulah constructed a madrasah and a mosque close to each other. ${ }^{3}$

When Nādir Shāh invaded India during the reign of the Emperor, he gave up Delhi to pillage, plunder and massacre. In the Tabșivätul-Näzi$\operatorname{rin}^{4}{ }^{4}$ it is mentioned that he passed this order while

1 Tärikhhi-Farrukhābādi, MS. in ASB, leaf 56; SiyarulMutaakhkhirin, vol. iii, p. 220.

2 Hearn's Seven Cities of Delhi, p. 45; Stephen's Arch. of Delhi, pp. 269 ff. ; Garcin de Tassey's Sayyid Ahmad, pp. 167-174; and Fanshawe's Delhi Past and Present, p. 247.

3 Asārul-Sanādìd, by Sayyid Ahmad, ch. iii, p. 8 r.

4 Tábsirātul-Nāzirin, MS. in ASB, by Sayyid Muhammad Bilgrāmī, p. 443. 


\section{PROMOTION OF LEARNING}

he was seated within the "Madrasah of Raushanuddaulah." 1 However, other writers state that Nàdir ordered the massacre of Delhi while he was seated in the Mosque of Raushanuddaulah, without referring to the madrasah. Be that as it may, Naddir carried away with him the celebrated Imperial Library of Delhi along with an enormous treasure on his return to Persia. This Library had been preserved by the Mughal Emperors as their most precious possession. ${ }^{2}$ By an irony of fate, some of these valuable books were afterwards sold in Persia at ridiculously low prices.

\section{3. $\underline{S} \vec{A} \vec{A} H$ 'Álam II.}

It appears that the royal family, after they had been deprived of their valuable library by the rapacity of Nädir, continued collecting books, which, in the reign of Shāh 'Ālam II (I759-I806), served to form a decent library, for it is mentioned in the 'Ibrat-Nämah that Ghulàm Qãdir, the fiend in human shape, who had most wantonly deprived the monarch of his eyes only three days before, went into the Jewel-house and took out a chest and a box of jewels, several copies of the Qur'an

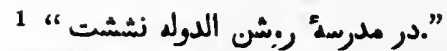

2 Martin's Miniature Painting and Painters of India, Persia and Turkey, vol. i, pp. 58, 77 . 
II.]

\section{THE MUGHAL DYNASTY}

and eight large baskets of books out of the Library. ${ }^{1}$

Hasan Razā Khān, the minister of Āṣafuddaulah of Oudh, founded a madrasah at Farrukhābād during Shāh 'Ālam's reign ; Maulānā 'Abdul Wahịid Khairābādī was a professor of that college. ${ }^{2}$

1 'Ibrat-Nāmah, by Faqīr Khairuddin Muhammad, Elliot viii, p. 249.

${ }_{2}$ Tärikhi-Farrukhābādi, MS. in ASB, leaf 124. 


\section{CHAPTER VI. \\ Female Education.}

WE have some evidence proving that female education was also cared for in Muhammadan India. No doubt the education of females was greatly restricted by the pardah system which stood in the way of females beyond a certain age being sent to schools, but there was no such obstacle so far as the young girls were concerned. Thus we learn from Ja'far Sharif that girls were taught in schools. He describes minutely in his Qanuini-Isläm ${ }^{1}$ the custom how a boy or a girl after having finished reading the Qur'ann makes presents to the teacher in an assembly invited for the purpose. The author further says that when a boy or a girl goes to school, it is the usual practice for the teacher to write an 'İdi (a verse of something relating to the 'Id) or a blessing for the child on a coloured or zarafshanni (illuminated) paper which is read by the child to the parents who make presents to the tutor. Whenever the pupil commences a new book, it is customary to entertain the teacher, to observe what is called

1 Qànüni-Isläm, pp. 47-50. 


\section{FEMALE EDUCATION}

Hadyah, and present him with money sent by the parents, on which occasion a half-holiday is given to the school. There can be no doubt, therefore, that young girls as well were regularly taught in schools. Besides this evidence of custom of sending girls to school, we have as an historical fact noticed before, that Raziyah, who succeeded Altamash on the throne of Delhi, was an educated princess. It appears also that Sulțān Ghiyāṣuddin, who reigned in Mālwa from 1469 to 1500 , established within his seraglio all the separate offices of the court, and had at one time, we are told, fifteen thousand women within his palace. "Among these were schoolmistresses, musicians, women to read prayers, and persons of all professions and trades." 1 The very fact that he retained schoolmistresses in the harem indicates that the ladies in the palace were taught by them.

At the time of the Mughal Emperors also, we have some examples at least of princesses being given a liberal education, and there is no reason to suppose that they lived and died in ignorance.

Gul-Badan Begam, the daughter of Bābar, wrote the Humainin-Namah as a contribution to the Akbar-Namah. Though there is no record to show how she was educated, yet there can be no doubt that she must have been a learned lady. It appears also that Gul-Badan used to collect books

${ }^{1}$ Ferishta vol. iv, p. 236. 
for a library of her own. ${ }^{1}$ Salima Sultāna, the niece of Humāyūn, being the daughter of his sister GulRukh, was a learned lady. She wrote many Persian poems under the nom de plume of Makhfī² (concealed). She became Akbar's wife after the death of her first husband Bairām Khān. We have already seen that Akbar's wet-nurse Māham Anaga was well educated, and founded a college in Delhi.

In Akbar's time, it seems, that regular training was given to the ladies of the royal household; for in his palace at Fatḥpūr Sìkrī, Akbar set apart certain chambers as a school for their education. I have given here a plan to show the relative position of the premises of the female school. ${ }^{3}$

Nūr Jahān, the celebrated wife of Jahāngīr, was thoroughly versed in Persian and Arabic literature, ${ }^{4}$ and it was she who carried on the administration of government during the lifetime of her husband, which indicates that she was intelligent and educated enough to understand the intricacies of affairs of all the departments of the State. Mumtāz Mahal, the beloved wife of Shāh Jahān, was well versed in Persian, and could compose poems in that language.

1 Humāyùn-Nämah of Gul-Badan Begam, by Mrs. Beveridge, p. 76.

${ }^{2}$ Malleson's $A k b a r$, p. 185 ; Blochmann's $\bar{A}^{\prime}$ ini-Akbari, p. 309.

3 Smith's Fathpür Sìkri, Pt. i, p. 8. Mr. Havell has also given a plan in his Handbook to Agra, etc., where the school also appears.

4 The Nineteenth Century, 1899, p. 756 (article by Justice Amìr 'Alì). 
II.]

\section{FEMALE EDUCATION}

Female

Educa -

tion.

Shāh Jahān's eldest daughter Jahānārā Begam was also educated, and encouraged the learned men of

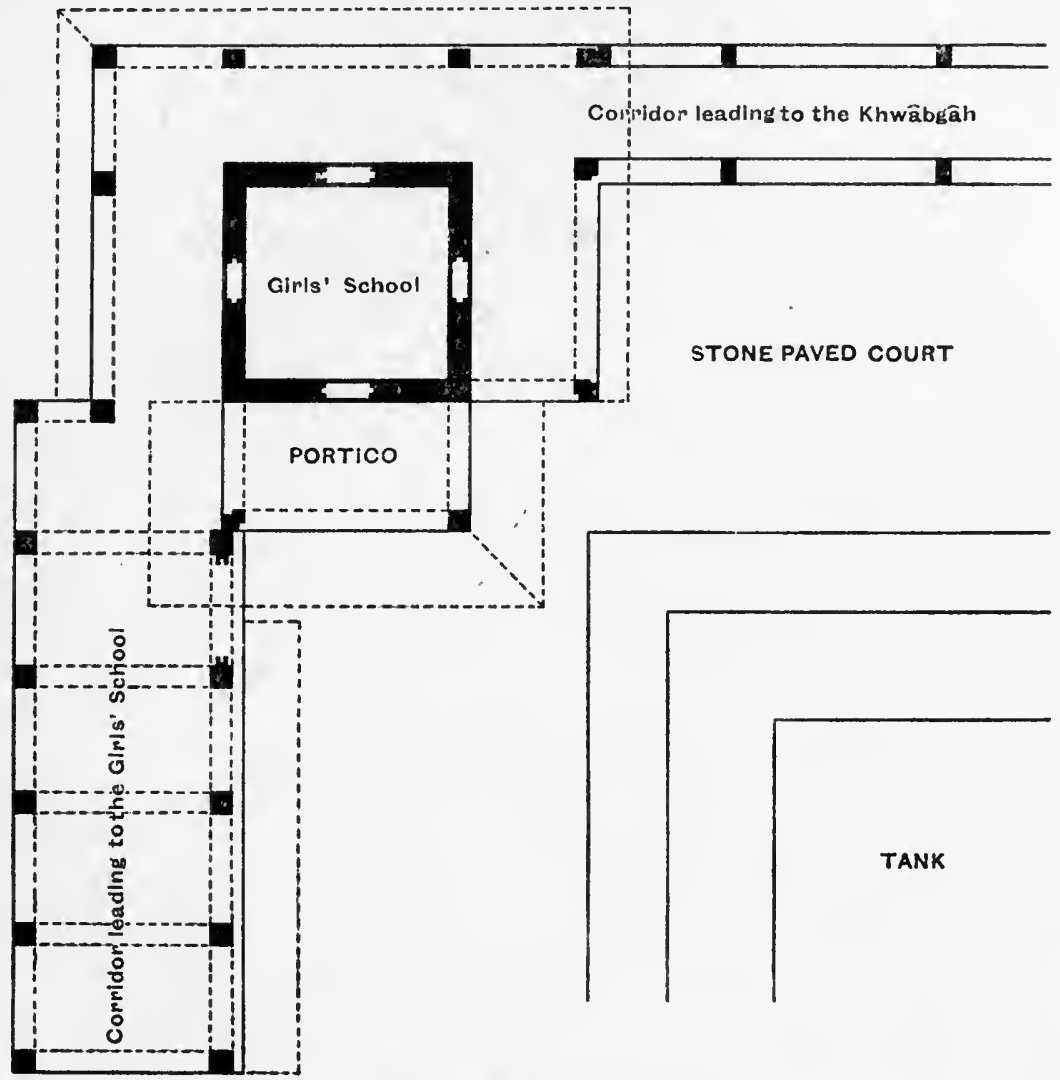

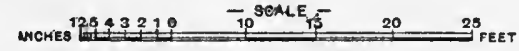

Plan of Girls' School in Akbar's Palace at Fathpūr Sīkrĩ.

(From Smith's Architecture at Fathpīir Sïkrï.)

the time with rewards and allowances. She wrote her own epitaph, which is characterized by deep humility and stern simplicity. The inscription runs thus :-

"Except with grass and green things let not my tomb be 203 


\section{PROMOTION OF LEARNING}

covered ; for grass is an all-sufficient pall for the graves of the poor." 1 The faqīr, the transitory one, Jahānārā Begam, disciple of the saintly family of Chistī, daughter of Shāh Jahān,-may God make her proof sure!

She ordered it to be placed on her own tomb, which is near that of Nizēamuddin Auliyā. Satiunnisā, a learned lady, was the tutoress of Jahānārā Begam. She could recite the Qurian and had a good knowledge of Persian. She was the female Nāzir to Mumtāz Maḥal, at whose recommendation the Empress gave pensions and donations to the daughters of poor scholars, theologians and pious men. $^{2}$ Zìbunnisā Begam, the eldest of the five daughters of Aurangzib, was an educated princess: she was taught by her own father, and was thoroughly proficient in the knowledge of the Qur'an. She knew Persian and Arabic, and was well skilled in the art of caligraphy. She employed many learned men, poets and writers, and to her were dedicated numerous compilations and original works. Aurangzib's third daughter, Badrunnisā, though she knew the Qur'an by heart, was not so well educated as her eldest sister. ${ }^{3}$

Though the Indian ladies and princesses did not attain to that degree of literary education as the Muslim ladies in Spain, e.g. Zainab, Hamda,

1 Hearn's Seven Cities of Delhi, p. I16. Also S. Ahmad.

2 Prof. J. Sarkar's Anecdotes of Aurangzib, pp. I 5 I, 173.

3 Ma'ásiri-'Álamgìrī (Bibl. Indica), pp. $538 \mathrm{ff}$. 


\section{FEMALE EDUCATION}

Fātimah, 'Āishah, Maryam, etc., ${ }^{1}$ yet it will be observed from the examples we have cited that the education of the Muhammadan princesses of India was not neglected; and sometimes they did show some progress which was indeed creditable, considering the comparative seclusion in which they were placed. These examples must have been followed by the nobility and the higher classes of Muhammadans in India. Hence we are justified in the conclusion that the Muhammadan ladies during the Muhammadan rule could not have been so ignorant as it is generally supposed.

1 Justice Amir 'Alì's Short Hist. of the Saracens, p. 569; Condé's Arabs in Spain, vol. i, p. 484. 
$\because$ 
THE following pictures are reproductions of old paintings in the collection of Mr. G. C. Manuk, Bar-at-Law, Bankipore, whose notes thereon are thus given :-

(I.) The first picture shows a Mughal princess having her lesson. The painter is unknown, but the quality of the picture shows its time to be that of Akbar.

(II.) The second picture shows a group of Muhammadan saints and maulawis. The painter is unknown, but it probably belongs to the time of Shāh Jahān.

(III.) In the third picture is represented the story of Haqiqat Rāi of Lahore, about two hundred years old. Haqiqat Rāi was a Hindu student in the school of a bigoted Maulawi. In the illustration, he is undergoing a severe punishment amounting almost to torture for his suspected insult to the Muhammadan religion. 



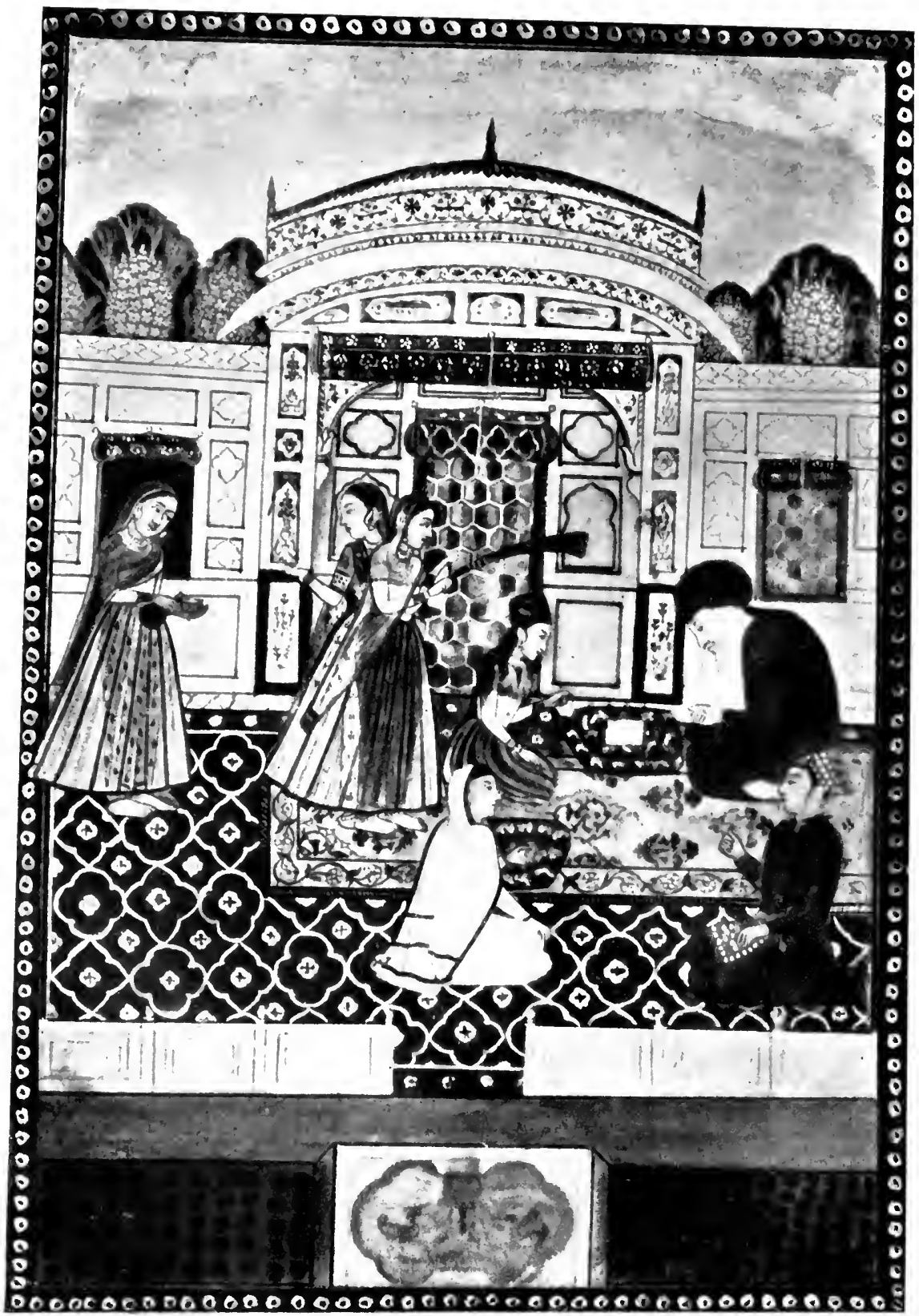

(I.)

A Mughal Princess having her Lesson.

(From the collection of Mr. G. C. Manuk, Bar-at-Law, Bankipore.) 


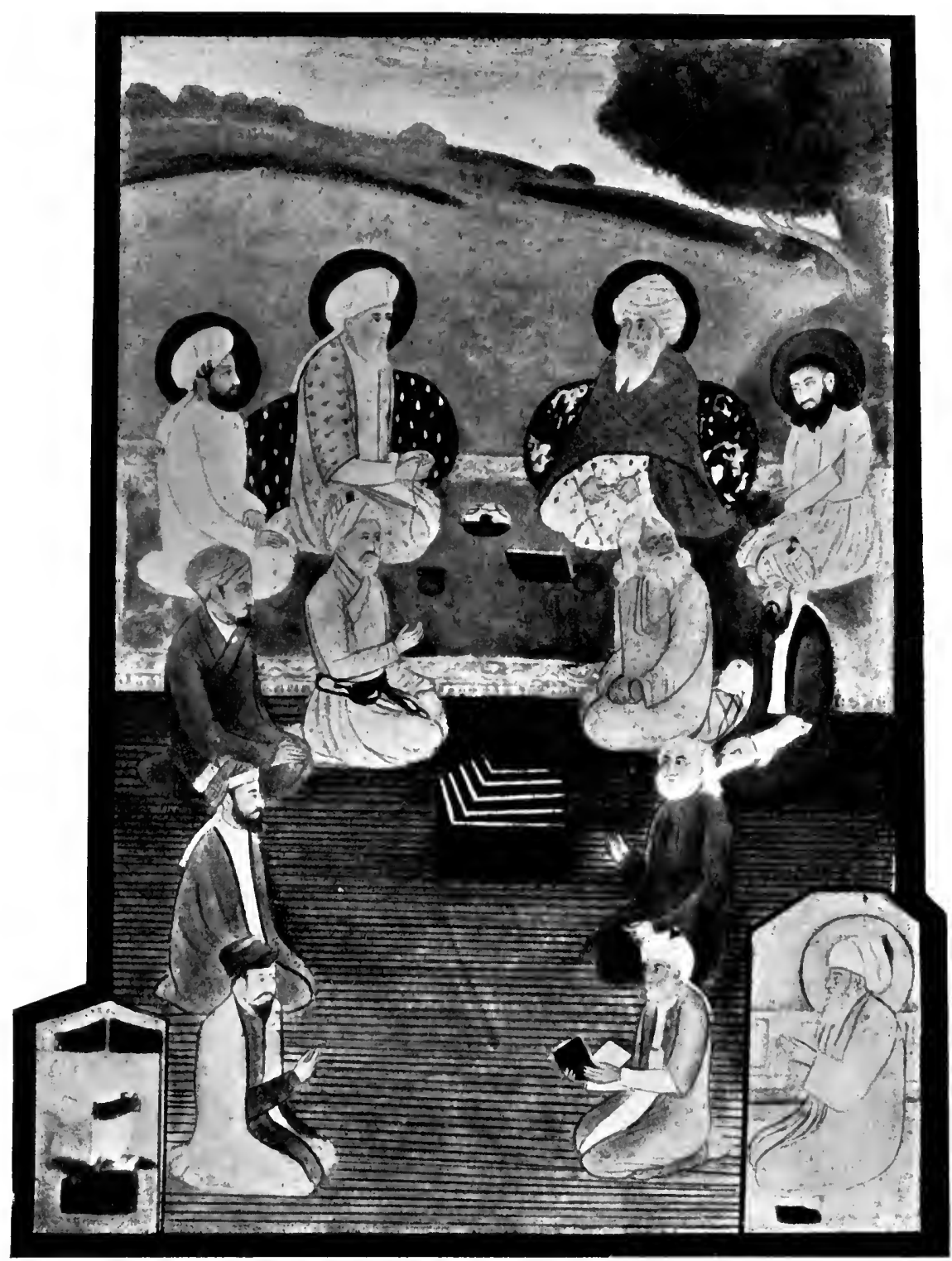

(II.)

A Group of Muhammadan Saints and Maulawīs, probably of Sḥ̄̄h Jahān's time.

(From the collection of Mr, G. C. Manuk, Bar-at-Law, Bankipore.) 
$\because$

( ' : '

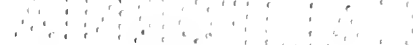




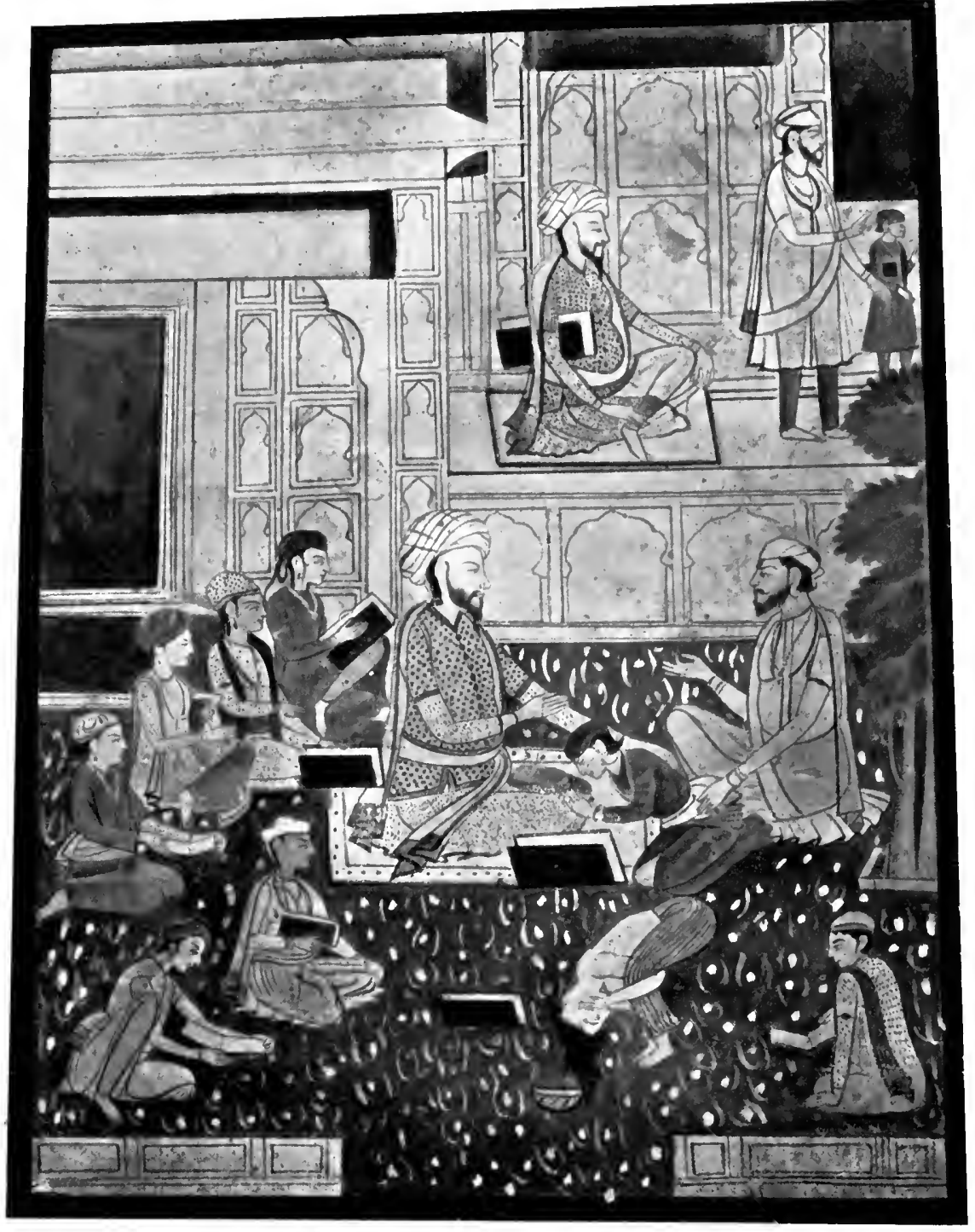

\section{(III.)}

IJlustration of the Story of Haqiqat Rāi of Lahore. (From the collection of Mr. G. C. Manuk, Bar-at-Law, Bankipore.) 
\begin{tabular}{c}
$\vdots$ \\
$\vdots$ \\
\hdashline
\end{tabular}

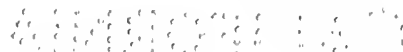




\section{ADDENDUM ON THE QUESTION OF AKBAR'S ILLITERACY}

IN continuation of Book II, Chap. III, pp. I39-I42 of this work, I should like to add a few remarks on the question whether or not Akbar could read or write the alphabet or the numerals. My erudite friend, Mr. Beveridge, who holds the opposite view, relies on the statements of Catholic missionaries as set forth below :-

(I.) A Monserrat: " $\mathrm{He}$ (Akbar) can neither read nor write, but he is very curious, and has always men of letters about him, whom he gets to discuss on sundry topics and tell him various stories." ["Father A. Monserrate's Account of Akbar (26th Nov., 1 582)," edited and translated from Portuguese by Rev. H. Hosten, S.J, in F.A.S.B., 1912, p. 194. See also Memoirs of A.S.B. (edited by Rev. H. Hosten, S.J.), vol. iii. No. 9, p. 643, for the Latin text of the passage. Cf. J. B. Peruschi, S.J., Informatione del Regno e stato del gran Re di Mogor . . ., Brescia, P. M. Morchetti (1597), which contains extracts from various letters, and is based for the greater part on Monserrate's Relaçam do Equebar, Rei dos Mogores (see Memoirs of A.S.B., vol. iii., No. 9, p. 540). The Asiatic Review, July I, I915, p. 52, gives from this compilation a passage bearing on Akbar.]

(II.) Jerome X'avier: "The king (Akbar) is gifted with a wonderful memory, so that, although he can neither read nor write, he knows whatever he has heard learned men discoursing about, or whatever has been read to him." ["Father Ferome X'avier," by Mr. H. Beveridge, in F.A.S.B., 1888, p. 37, giving an extract from a letter of Father Jerome X'avier, dated 1598 A.D. It has been utilized by E. D. Maclagen in F.A.S.B., I 896, p. 77. I 


\section{ADDENDUM}

consulted Rev. H. Hosten, S.J., St. X'avier College, Calcutta, about this point. He kindly supplied me with many of the references quoted here.]

Monserrat was at Akbar's Court from 1580 to 1582 , and Jerome X'avier was also there for a few years; and statements proceeding from such personages are no doubt worthy of belief and respect. But should any remarks be found in their works or letters, which are found to be contradicted by the cumulative evidence of quite a number of facts and circumstances, the force of which is strong enough, the precise value of the aforesaid kind of evidence has to be carefully weighed.

In this connection I should like to point out how the evidence of the Greek "observers" of India is valued by the critical methods of historical research. As an instance, Professors Macdonell and Keith, while treating of the position of the king in regard to land in those times, refers to the Greek notices on the subject as those "in which unhappily it would be dangerous to put much trust, since they were collected by observers who were probably little used to accurate investigations (of such matters), and whose statements were based on inadequate information." [Vedic Index of Names and Subjects, vol. ii, p. 214 ; cf. Professor Hopkins, Fournal of the American Oriental Society, xiii, pp. $87,88 \mathrm{f} . \mathrm{n}$., for an example of the way in which Megasthenes' description of the "seven social orders" has to be taken for historical use,]

In the present case, to get at a correct knowledge of the truth or degree of the Emperor's literacy or illiteracy was not very easy for foreign missionaries in the environment of distrust and suspicion in which they lived and moved in the Court of a Mughal monarch surrounded with his peculiar "pomp and circumstance," which did not at all favour curious inquiries into a personal question of the present kind relative to the Emperor. At best, remarks on such a question would be based on hearsay evidence, and not at all on first-hand, and would be valued as such. In holding this opinion on the present point, I am but following Monserrat himself, who does not say that all the information garnered in his work is first-hand. Says he: "As to the particulars concerning Cinguiscan, Temurbeg, the Scythians and the Mongols 


\section{ADDENDUM}

(i.e. Mughals), which I have, so to say, borrowed and inserted after my narrative, at the end of this first book, I learned them, in the first place, from King Zelaldin himself ; then from a journal containing an account of the travels of a certain ambassador of Henry IV, King of Castille, to Temur ; finally, from many writers of no mean authority." [Memoirs of A.S.B., vol. iii, No. 9 (also quoted above), p. 520.]

Besides, it should be noted that observations in the accounts left by the Catholic missionaries are not always absolutely flawless. Rev. H. Hosten points out several inaccuracies in Monserrat's account; e.g. (I) his speaking of persons kissing (instead of putting their heads on) the Emperor's foot (F.A.S.B., I912, p. 202, f.n. 4); (2) his mention of the river Narbada passing through Aḥmadābād (Ibid., p. 206, f.n. 4) ; (3) his mention of the Chambal as an affluent of the Indus (Ibid., p. 206, f.n. 5) ; (4) his reference to the rule of Christian kings at Delhi in Timur's time (Ibid., p. 207 , f.n. II) ; (5) his mention of commands of 12,000 or 14,000 in Akbar's military organization (Ibid., p. 210, f.n. 3).

The evidence quoted below, on the other hand, has every reason to be regarded as first-hand, coming as it does from one who was the Emperor's co-religionist and personal favourite, and had greater facility for observing his habits and movements in his informal hours. Abul Fazl, in his $A^{\prime}$ ini-Akbari (Bibl. Indica edition, Bk. I, $A^{\prime}$ in , 34, p. I15, lines I I, I2), mentions that Akbar used to listen daily to the perusal of books by paid readers, their remuneration depending on the number of leaves read; and that on the last of the leaves perused, Akbar wrote daily with his own pen in numerals the number of leaves gone through, on the basis of which the remuneration was calculated and paid in cash to the readers there and then. The passage runs thus: "Wa har ruz ke badān jā rasad, ba shumārah-i-ān, hindisah baqalam gauharbār naqsh kunand. Wa ba'adad awrāq khwānandah rā naqd az surkh wa sufaid bakhshish shawad." ["Whatever place (of the book, the reader) daily reached, he (Akbar) wrote with his own jewelled pen numerical figures according to the number of leaves (read). He paid the readers cash in gold orl silver according to the number of leaves (read)."] Blochmann's rendering of this passage is not explicit, owing to his omission to take note of the 


\section{ADDENDUM}

word "hindisah (numerical figures)." [See Blochmann's $\overline{A^{\prime}}$ ini$A k b a r \overline{,}$ p. 103 ; cf. Gladwin's $\bar{A}^{\prime} \bar{i} n i-A k b a r \bar{i}$, p. 85 , which mentions Akbar's practice of writing the date of the month on the page where the reader stopped.] The passage plainly attributes to Akbar a knowledge of the numerical figures and their daily transcription with his own hand and pen on the pages of the books. It is a common practice to make a boy learn and write the numerical figures along with or even subsequent to the letters of the alphabet, and I do not think that Akbar had been in his boyhood an exception to this rule. Be that as it may, the passage testifies to Akbar's ability to write, and read at least the numerical figures.

There are also a few facts worthy of mention in this connection. Akbar was the son of a learned father who was remarkable for his literary tastes, and as became such a father and the responsible head of the imperial household, the education of the heir-apparent came to be the care of the State at the earliest possible moment. As soon as "consciousness" dawned upon the child, there was appointed a regular tutor to take charge of his training. Maulānā A'zamuddin was engaged in 1547 when Akbar was only four years, four months, four days old-the customary age with the Muhammadans for beginning education. He was succeeded in his office by Maulānā Bāyazìd, who was again followed by a number of teachers. Mīr 'Abdul Lațif, Pīr Muḥammad Khān and Hājī Muhammad Khān were some of his tutors at different times, whose names we know. There were, besides, the military tutors, e.g. Muni'm Khān charged with the duty of training up the future Emperor in the art of war to which he owed his extensive conquests. [For the references, see pp. 140-142 of this work. The Urdu work, Darbār-Akbari (by Maulānā Muhammad Husain Azad, Professor of Arabic, Government College, Lahore) mentions, at pp. I I2, I I3, the first four of the aforesaid tutors, and adds one, Maulānā 'Abdul Qādir. As no references are found in it to the authorities upon which the statements are based, it cannot be of much help to me for the present purpose.]

Thus we see that care for Akbar's literary education commenced from 1547, when he was only about five years old, and 


\section{ADDENDUM}

continued up to 1555 , the year of Humāyūn's death, and a few years beyond it, even assuming that no teachers were engaged for him after the last of the aforesaid five. Of this period of training, even though limited by the above assumption, no less than eight years (1547 to 1555) belonged to the period of Humāyūn's fatherly solicitude for his son's training, the remaining years being passed under Bairam's guardianship. In 1555, Akbar was still a boy of about thirteen years of age. He was under the stern Bairam's guardianship for about five years. The many dismissals of tutors indicate that both Humāyūn and Bairam paid attention to his education. Even granting that he was idle and fond of sports, I do not understand how a boy, however recalcitrant he might be, could so systematically resist all attempts at training him for at least ten or twelve years on the part of his guardians so as to come out at the end of the period without the modicum of capacity for reading and writing the few letters of the alphabet. Nor can it be believed that the child of five or the boy of fourteen and still in tutelage could insist on his own peculiar mode of training himself so as to enjoy the luxury of having books read out to him in order to make himself educated by the use of his ear alone. Akbar was very intelligent, and a month or two snatched out for studies out of the whole period of his training, or devoted to them under the fear of his guardians, could, no doubt, have enabled him to read and write the alphabet, which even the dullest boy does not take long to master.

As regards the passage in the Tiuzaki-Fahängirin, on which Mr. Beveridge relies, I now notice that it is capable of a different interpretation. The word "ummi" in the text has been taken to mean "unable to read or write," but the Muhitu'l-Muhit (vol. i. p. 40) includes among the meanings of the said word that of "taciturn" (al-qalīlu'l-kalām), and this meaning will be quite in accord with the context of the aforesaid passage. The passage thus interpreted would run as follows:-

"My father (Akbar) often kept company with the learned men of all persuasions, particularly with the Pandits and learned men of Hindustan. Though he was taciturn, yet from his constant association with the learned and wise, nobody could discover in his conversation that he was a man of taciturn disposition. In 


\section{ADDENDUM}

regard to the elegances of prose and poetry, there was nobody more proficient than he."

Had Akbar been actually illiterate, he could have certainly, by dint of his genius, managed as satisfactorily the State affairs as other distinguished Eastern administrators devoid of literary equipment had done. But as things stand, he does not appear to belong to this class.

I should also remark, at the risk of repetition, that Akbar appreciated abstruse controversies and elegances of literary compositions, took part in discussions with learned men, composed poetry, recited odes of Hāfiz, and was well-read in history. These as well as the learning they imply come as more natural corollaries to his knowledge of the alphabet than to his ignorance thereof. [For the references, see pp. 139-142 of this work.]

In concluding this note, I may state that Mr. Beveridge himself has not felt positive about the subject under discussion. In his translation of the $A k b a r-N a \overline{m a h}$ (vol. i. p. 518 n.), he writes, "It seems probable, too, that Akbar never knew how to read and write." 


\section{INDEX I.-SUBJECTS}

Abbreviations, Table of, xxxi.

Accounts, 93, 16I

Actors, 24

Afghāns, 125, 178

Agra :

Bahlūl's foundation, 72

Capital transferred to, by Sikandar, 73

Colleges at, in Akbar's time, 163

Famous centre of learning under Mughals, 175

Agriculture, 16I

Ahli-Daulat, Ahli-Murād, and Ahli-Sa'ādat, I29

Aḥmad Nizām Shāh, of Aḥmadnagar :

Educated in captivity, 94

Introduces single-stick, 95

Akbar the Great :

Christianity taught to his son, 160

Co-education of Hindus and Muhammadans first organized in his reign, $160,17 \mathrm{I}$

Colleges of his foundation, $162-163$, I 71

Diary, official, I 5 I

Educational improvements of his promotion, 160

Encouragement of mechanical arts and sciences, 164, 165 (note)

Evidence as to his literacy, xix., $139-142,207-212$

Fondness for books and learning, 142-144, I 5 I

Friendliness to Christianity, 146, 160

Given title of Mujtahid, 146

'Ibādat Khāna and the famous assemblies therein, I44-I 47, $17 \mathrm{I}$

Illustrations of books, his fancy for, 153

Interest in Hindu literature, $147-150,171$

Jesus Christ, his reverence for, 160 (note)

Liberality of his views, 146,172 


\section{INDEX I}

Akbar the Great-continued.

Library, the royal, I 5 I-I 52

Life attempted from college roof, I66-167

Music and musicians, his patronage of, I $55^{-1} 57$, I 72

Painting, encouragement of, $154-155,172$

Persian, improved method of teaching, $16 \mathrm{I}$

Practical jocularity, I 45

Rewards and stipends to the learned, $168-169,172$

Salient features of his reign, I70-172

Science teaching, order of, in his reign, $16 \mathrm{r}$

Systematic protection of Hindu learning, I 7 I

Translations made by his order, 147-1 50, I7 I

Unique position in Indian literary world, I7I

'Alāuddīn Khiljī, Sulțān :

Arrogant though uneducated, 32

Benefits to poets and historians, 36

Capricious favours to the learned, 33, 34

Confiscates endowments, etc., xlvii., 35

Generous nobles of his reign, 37,116

Learns privately to read Persian, 33

Neglects his sons' education, 32

Paradoxical importance of his reign in literary history, 39-40

Prominence of literature in his reign due to activities of preceding rulers, etc., xlvii., II 4

Question of his literacy discussed by Mr. Beveridge, xix.-xxi. Allusions and references, value of, in historical research, ix.

Almshouses, 28, 32, 45

Alphabet, Persian, how taught in Akbar's time, I6I

Altamash, Sulțān, liberal patron of Muhammadan learning, xviii., 20-2 I

Amirs, 176, 194

Arabic language :

Kalīlah-Damnah translated into, 15

Knowledge of, necessary to administrators, 64

Known to learned Hindus under Fìrūz Shāh Tughlaq, 64-65

Taught at Nishāpūr, I9

Translations of Indian works into, 13

Archæology, Fīrūz Shhāh Tughlaq's taste for, 52

Architecture, Saracenic, 95

Arithmetic, 161

Artists, encouraged by 'Adil Shhāh, 92

Asoka Columns :

Legendary lore of, 52

Removal of, by Fīrūz Shāh Tughlaq to his capital, 52-54, I7 I 


\section{INDEX I}

Assassinations, attempted, of Emperors, 166-167

Astrologers, 39

Astrology :

Classed in Akbar's Library with poetry, medicine, and music, 152

Indian, studied by Muhammadans, 13, 70 (note)

Practical applications of, by Humāyūn, I29, I 3 I, I42

Study of, leads to Humāyūn's death, I 33

Astronomers, 12, 81, 85, 197

Astronomy :

Astronomical Tables, 125, I50, 197

Classed with Șúfiism and philosophy in Akbar's Library, 152

Fīrūz Shāh Bahmanī's fondness for, 85

Indian, studied by Muhammadans, 13

Instruments of, in Delhi Observatory, 197

Observatories, 85, 125, 196

Taught at colleges in Akbar's time, I6I

Athletes, 54

Aurangzib, Emperor :

An anti-Hindu monarch, I 87

Assists students according to proficiency, 188 (note)

Captures Bĩdar, with disastrous results to the college, 88

Despiser of the arts, 19 I

Despoils library at Bỉjāpūr, 94

Division of his time, I92

Early education, his, 190-19I

Educates his daughters, 204

Fosters Muslim education and learning, 187

Founds numberless schools and colleges, 187

His grants to education, $188-189$

Love of theology, 193

Meets personal expenses by his penmanship, 192-193

Orders destruction of Hindu schools and temples, 187

Orthodox and Puritanical, I9I

Progressive, apart from anti-Hindu bias, 187

Provides education for the Bohras of Gujrāt, 188

Turns Dutch buildings into college for Muslims, 188

Views on the education of Princes, 192

Writer of letters, xxvii.

Autobiographies, royal :

Bābar's, I22, I23, I 24, 126, 147, I 50, 15 I

Fīrūz Shhāh Tughlaq's, 50

Jahāngïr's, I 39, I 5 I

Tìmūr's, 67,68 


\section{INDEX I}

BĀBAR, Emperor :

Author, poet, and musician, I 2 I -I 22

Critical knowledge of Arabic, Persian, and Turkī, I 2 I

Dislike of Mughals, xxiv.

Education, 123

Generosity to the learned, 123

Hindustan, his criticism of, xxv., 124

Illustrations in his Memoirs, 126

Initiator in penmanship, 123

Literary companions and parties, 123

On colleges in India, xxiv., 124

On Indian observatories and astronomical tables, 125

On the library of Ghāzi Khān, 125-126

Painting, interest in, 126

Public Works Department, postal and educational duties of, I26-I 27

Verse, style of, invented by him, I 22

Writings on prosody, music, jurisprudence, and religion, 122

Bahādur Shhāh, Emperor :

Colleges of his reign, 194-195

Diminishing glory of Muhammadan rule, 194

Bahlūl, Sulțān :

Founder of Agra, 72

Student of Muhammadan law, 72-73

Bahmani Dynasty, education under, 90-9 I

Kingdom, 80-9I

Bairām bin Mas'ūd, Sulțān :

His thirst for knowledge, 14

Translations to his order, I 5

Balban, Sultān :

Advises Prince Muhammad, 27

Entertains refugee princes, 23

Friend of literature and learning, 23

Influence of his sons, 24-26

Visits learned men at their homes, 27

Belles Lettres:

Encouraged by Sulțān Sikandar, 74

Kabīruddīn, 39

Bengal, Kingdom of :

'Alīwardī Khān, hospitable and liberal to the learned, I I 2

College ruins of Yūsuf Shāh's time, 108

Ghiyāșuddīn, Governor, encourages art and letters, and builds a college at Lucknauti. I06

Ghiyāșuddin II., Sulțān, poet, 108 


\section{INDEX I}

Bengal, Kingdom of-continued.

Husain Shäh, Emperor, great patron of Bengali, and founds college in memory of Quttbul 'Alam, I09

Mīr Qāsim, patron of learning, I I2-I I3

Murshid Quli Ja'far Khān, learned, religious, and skilled with the pen, I I I-I I 2

Nāsir Shāh orders translation of Mahābhärata into Bengali, I07

Rājah Kānis bestows pensions on the learned from motives partly political, 106-107

Ruins of madrasahs attributed to Husain Shāh, IO9-1 IO

Bengali language :

Affinity to Sanskrit, 107

Attracts notice of Muslim rulers, 107

Bhāgavata Purāna translated into, by Mālādhar Basu, I09

Mahābhärata translated into, by Kïrttivāsa, 108

Parāgal Khān and his son promote translation, I ro-I I I

Patronage of, by Muslim monarchs copied by Hindu rājahs, I I I

Rāmāyana translated into, 107

Sanskrit and Persian books ditto, I I I

Bibliography, xxxvii.

Bibliophiles, I76

Bīdar, Maḥmūd Gāwān's College at :

Described by Meadows Taylor, 87

Desecrated by Aurangzib, 88

Library, 89

Mosque, 88

Partially destroyed by explosion, 88

Splendid ruins, 88 (note)

Various accounts of its destruction, 88 (note)

Bījāpūr :

Ancient city of Hindu learning, 9 I

Conquered by Muhammadans, 91

Derivation of the name, 9 I

Reputation maintained under Muhammadans, 92

Ruins of its Hindu college, 92

Bījāpūr, Kingdom of :

'Ádil Shāh, skilled in music and kind to musicians, 92

Ibrāhīm 'Âdil Shāh I., placed Brāhmanas in charge of the public accounts, which began to be kept in Hindi instead of Persian, 93

Ibrāhīm 'Ädil Shāh II., maintained at his court the great historian, Muhammad Qāsim, 94

Ismā'îl 'Ādil Shāh, adept in fine arts, preferring Turkish and Persian, 93 


\section{INDEX I}

Bījāpūr, Kingdom of-continued.

Yūsuf 'Ādil Shāh, married a Mahratta wife and admitted Hindus to his revenue department, 93

Biographers :

Abdul Haqq Dihlawi, 178

Mullā 'Abdul Karīm Sindī, 87

Prince Dārā Shikūh, I86

Bohras of Gujrăt compulsorily educated under Aurangzib, I 89

Book illustration :

As old as the time of Bābar, 126

Bābar's Memoirs, 126

Fahängì-Nämah, I26, 178

Works in Akbar's library, 153

Botany, lectures on, 84

Brāhmaṇas, 74, 75, 81, 86, 91, 93, 145, 146, 184 :

Acquire influence in Bījappūr, 93

Colleges of, destroyed by Aḥmad Shhāh Bahmanī, 86

Contempt of, for Bengali mitigated by example of Muslims, I I I

Courage of, in controversy, 74-75

Occupations pursued by, 8I

Specialize in the revenue department, 93

Take office under Muslims, $8 \mathrm{I}$

Buddhists, I9, I45, I 72

CALIGRaphists (fine penmen):

Attached to Akbar's court, I 59

Employed on scientific works under Sikandar, 77

Royal, 14, 22, 44, 84, I I I, I23, 192

Caligraphy (fine penmanship):

Akbar's encouragement of, I 59

Bābarī hand, designed by Bābar, I 23

Cultivated by Muhammadan Emperors, I4, I 58

Indian Fables in, to Akbar's order, 142

Large sums paid for, 69

Modes of, in Akbar's time, 158

Muhammad Tughlaq's mastery of, 44

Nașiruddīn, Sulțān, earns his food by, 22

Prices, high, for MSS., I76

Razm-Nâmah MS., said to have cost Akbar $£ 40,000,153$ (note)

Caprice, a Sultān's, ruinous effects of, 46-47

Censors of literature, $5,7,48$

Chahār Minār, College at Haidarābād:

Founded by Muhammad Quli Quțb Shāh, 95

Visited and described by Thevenot, 95 


\section{INDEX I}

Chāghtā'ì Turkī, language, I9 I

Chārbāks, 145

Christianity :

Abul Fazl commanded to translate the Gospel, 146, I 50

Akbar's liberal attitude to, 146

Akbar's son instructed in, 146,160

Christians, $145,146,172$

Classification of people, Humāyūn's, 129

Clepsydra, or water-clock, xxiii., 55

Colleges (Madrasahs), I2, 18, 20, 2 I, 22, 23, 47, 57, 58, 59, 69, 7 r, $74,82,86,87-89,91-92,95-96,97,98,99$, 101-104, 105, 106, 108, 109, 1 10, 124, 1 33, 1 34, 137, 163, 165-167, 168, 175, I81, 182, 187, 188, I 89, 194-195, 196, 197, 198, 199

Alleged deficiency of, in Hindustan, xxiv., 124

Day colleges in Delhi, 163

Denominational character of Fìrūz Shāh's foundation, 64

Destruction of, by Sikandar Lūdī at Jaunpūr, IOI

Fìrūz-Shāhī-Madrasah, 6o-63, 64

Inspection under Delhi Emperors, I03

Copper, public notices engraved on, 105-106

Copyists, Indian, 177

Court of Women in Mālwa, 20I

DANCERS, 24, 90

Dārā Shikūh, Prince :

Conversion to Șüfïism, I 85

Learning, I 84

Reverence for the $V e d a s$, I 84

Translations from Sanskrit, 185

Writings, 186

Darwishes, I79

Deccanese, 83, 93

Delhi :

Asylum and resort of learned men, 20, 23, 27

Attacked by heretics, 22

Capital of Muhammadan India, I 16

Compared with Bukhārā, 28

Rich in literary societies, 24

Ruined by Sultān's whim, 46, 47

Sacks of, 67, 197

Discussions in Akbar's famous 'Ibādat Khāna, I44-147

Divinity, 162

Dutch buildings confiscated by Aurangzib, I 88 


\section{INDEX I}

EATING, court etiquette of, under Sikandar, 76-77

Economics, I6I

Education, compulsory, 189

Education, Hindu :

Independence of, under first Muhammadan rulers, xlvi.

Loses State patronage after Muhammadan invasions, xlv.

Not encouraged under Maḥmūd, 3

Not practicable at Muslim colleges, 64

Progress of, checked by profligate Sulțān's example, 28-29

State patronage of, restored by Akbar, I60, I7 I

Technical improvements under Akbar, I6I

With Muhammadans, 160

Education, Indian, state of, under Shāh Jahān, I80-I 8I

Education of Princes, 190-192

Education of Women :

Princesses, 20I -205

Details of school customs proving prevalence of education of young girls, 200

Examples of educated Muslim Princesses show female education under Muhammadans to be less neglected than is generally supposed, 205

Female school in Akbar's palace, 202-203

Instances of educated ladies in Mughal times, 20I-205

$P$ ardah system an obstacle, 200

Schoolmistresses appointed for the harem by Sulțān Ghiyāșuddin of Mālwa, 97, 201

Education, technical :

Diffused by apprenticeship, I I 7

In arts and crafts, Fìrūz Shāh Tughlaq's provision of, for slaves, 55, I I 7

In government, Fìrūz Shāh Tughlaq's training, 50 Muhammad Ghüri's slave protégés, I 8

Emperor as literary barometer, xlvii.

Endowments of learning :

Academies, by Tīmūr, 69

Aurangzib's assistance to Akramuddin Khān Șadr, I 88

College of Ghāziuddinn, 194-195

Qututbul 'Allam, by Ḥusain Shāh, 109

Colleges, etc., by Fìrūz Shāh Tughlaq, 56, 57, 58, 63

Confiscated by 'Alāuddīn Khiljī, restored by his successor, $35,4 \mathrm{I}$

Ghaznī University, by Mahmūd, 5

Influenced by royal example, xlvi.

Madrasahs, by Ḥusain Khān, Walī of Kashmīr, 106 


\section{INDEX I}

Endowments of learning-continued.

Schools and colleges, by Mas'üd, 12

for orphans, by Maḥmūd Shhāh Bahmani, 83

Enigmatists, I 23, 127, 134

Epitaph of Jahānārā Begam, 203

Example, bad, in high places, effects of, xlvii., 28-29, 90

Extempore verse-making, 7, 8, 84, 108, I23, I 38

FENCING :

Introduced by Aḥmad Nizām Shāh, 95

Schools for, founded in Ahmadnagar, 95

Fiction :

Indian Fables of Mīr Hamzah, Akbar's fancy for, ${ }^{4}{ }^{2}$

Indian, translated into Arabic and Persian, 13

Muhammad Tughlaq's indifference to, 45

Firdausī :

Approves himself a poet, 8

Completes Shäh-Nämah, 8, 9

Is meanly paid by Mahmüd, xvi., xvii., 9

Lampoons the Sulțān, xvi., 9

Reparation made too late, Io

Fìrūz Shāh Bahmañ̄ :

Accomplished in languages and science, 84

Astronomy, his love of, 85

His harem of many nations, 84

Observatory, builds an, 85

Poetical and literary pursuits, $84-85$

Sees through a pretender to learning, 85

Sends ships abroad for learned men, 85 , I 15

Fīrūz-Shāhī-Madrasah :

Described by Barnī, 60-63

Exclusively for Muhammadans, 64

Question of identity with college on side of Hauz Khāṣ, 60-6I (note)

Fìrūz Shāh Tughlaq, Sultān :

Administrator, a good, 49

Archæology, first Sulțān to show taste for, 52

Art, liking for, 54,55

Autobiography, 50

Builds a palace for scholars and noblemen, $5 \mathrm{I}$

Builds himself a capital, 49

Colleges of his foundation, $57,59,60-64$

Digs canals, xxiii., 57

Diversions, 54

Educational zeal, 5 I, 56, I I7 


\section{INDEX I}

Fìrūz Shāh Tughlaq, Sulțān-continued.

Education and training in Government, 50

Fīrūz-Shāhī-Madrasah, $60-63$

Founder of Jaunpūr, xxiii., 100-10I

Hindu monuments, care for, 52-54, 58

History, fondness for, $5 \mathrm{I}$

Orders translation of Hindu books into Persian, $64-65$

Parentage, xxii.

Provides for poor scholars, 66

Public works, maintenance of, 56

Religious ardour, 54 of his reign, $56-57$

Science, interest in, 55

character of his colleges, 64

Slaves, fancy for, $54-55$, I I 7

Translations from Sanskrit into Persian in his reign, 70 (note)

Firūzābād :

A famous city of learning, 49

Eclipses Delhi, to be itself eclipsed, I I6

GAZETTE, publication of, an affair of State, I 27

Geomancy, I6I

Geometry :

Lectures on, before Fīrūz Shhāh Bahmanī, 84

Order in which studied at colleges, I6I

Ghazni, city of :

Becomes famous for learning, 6

Devastated by 'Alāuddīn Ghūrī, I 7

Mahmund's love for, xv.

University at, founded by Mahimūd, 5

Globes, terrestrial and celestial, ordered by Humāyūn, 127

Golden arrows of rank, Humāyūn's, I 30-1 3 I

Government :

Brāhmanas first take part in, under Muhammadans, 8I

Fìrūz Sh̆̄āh Tughlaq's early training in, 50

Hindus admitted to, under Fīrūz Sh

Muhammad Ghūrī's slave protégés trained in, 18

Order of, among sciences taught in Akbar's time, 162

Grammar (Nahw), 38

Grammarians, 38

Grants to students according to proficiency, an idea of Aurangzib, I 87, I 88 (note) 


\section{INDEX I}

Gulkandah, Kingdom of :

Quțb Shāh, founder of the splendid Chahār Minār and other colleges and schools, 95-96, I I 5

HADİ, I9I, I93

Hāfiz :

Attempts visit to Maḥmūd Shāh Bahmanī, 82-83

Caps verse of Ghiyāșuddin II. of Bengal, I08

Timūr's respect for, 69

Handwriting :

Importance of, before invention of printing, I 59

Styles of, and their inventors, $158-159$

Harem of many nations, Fìrūz Shāh Bahmanīs, 84

Hebrew supposed to be known to Fìrūz Shāh Bahmanī, 84 (note)

Hindī language :

Bābar's scholarship in, I2 I

Bairām Khān's knowledge of, I69

Cherished by Hindus, 76 (note)

Prince Dārā's rings, 185

Supersedes Persian in Bijāpūr for public accounts, 93

Translations into, by Akbar's order, 147

Hindus, $3,40,64,65,74,75,76,86,93,94$, I I 2 , I I 3, I 25, I 47, I 57 , I 7 I, I72, 184,185

Admitted to revenue department of Bījāpūr by Yūsuf 'Ādil Shhāh, 93

Appointed to Government offices by Fìrūz Shāh Tughlaq, 64

Co-educated with Muhammadans, 160

Intermix with Muhammadans, 40

Reach Muhammadan standard in Persian learning, 76 (note)

Study Persian in reign of Sikandar, 75, 76

Hindustān, Bābar's criticism of, xxv., 124

Hindustani language (Urdu) :

Elements of, 76 (note)

Origin of, in Sikandar's reign, 75-76

Historians, 36, 38, 39, 5 I, 8 I, 94, I 32, I 5 I, 178, I 83

Historical works, Muhammadan :

Allusions in, perhaps more reliable than direct accounts, ix.

How used and compared, viii.

Mix facts with fiction, viii.

History (Badī' and Bayān):

Fondness of Sulțāns for, 44, 5 I, 97, I 32, I 37, I43, I44

Last of the sciences to be studied at colleges, I62 


\section{INDEX I}

Humāyūn, Emperor:

Astrological interests, I29, I 3 I, I 33, I42

Astronomy and geography, love of, 127

Books, fondness for, ${ }^{3} 32$

Ceremony of Maktab in childhood, 128

Classifies his subjects, 128

Days allotted for reception of each class, I 29

Distinguishes rank by golden arrows, I30

Halls of the Seven Planets, I 3 I

Madrasah built by him at Delhi, I 33

Meets death through a fall, I33

Tomb used as a college, 134

'IBĀDAT Khāna, I44-I47, I 7 I

Ibrāhīm, Sulțān :

Religious in disposition, 14

Skilled in penmanship, 14

Illiteracy not necessarily a disadvantage to rulers, $\mathbf{x x}$.

Ink, made in Kashmir, I90 (note)

Intestacy, Jāhāngī's law of, I74-175

JÄGIRS, I02, I03, 104, 188

Jahāngī, Emperor :

Education of, 173

Illustration of his Fahāngìr-Nāmah, I77, I78

Intestacy, his law of, 174

Love of books, I75-176

Memoirs, 174

Nūr Jahän, his learned wife and representative, 202

Patronage of painters, 176

Recreations with learned men, I 79

Restorer of ruined colleges, I75

Well versed in Turkish, 174

Jains, 145, 172

Jai Singh, Sewai, Rājā of Amber:

Builder of observatories, 196

His equatorial dial at Delhi, 197

Superintends preparation of astronomical table called Muhammad Shāhī, 197

Jami' Masjids, 22, 52, 58, 62, 68, 87 (note), 95, I0I, I04, I66-167,

Jāṭs, 196 $\mathrm{I} 8 \mathrm{I}, \mathrm{I} 89$

Jaunpūr, Kingdom of:

Husain Sharqì, Sultān, inventor of Khiyāl, I 57-I 58 


\section{INDEX I}

Jaunpūr, Kingdom of-continued.

Ibrāhīm Sharqī, Sultān, patron of learning and letters, 99, 100

Wife of Mahmūd Shāh builds and endows a college, IOI

Jaunpūr, University City of :

Called the Shìrāz of India, IO4

Conquered and crushed by Sikandar Lüdi, IOI

Famous centre of learning under Ibrähîm Sharqī, 99, 100

Founded (I37I) by Fìrūz Shāh Tughlaq, IOO-IOI

Government inspection of and grants to colleges, IO3

inspector confiscates stipends and jägirs, IO3

Origin of name, xxiii.-xxiv.

Students' expenses met by letting apartments, 102

Visited by Duncan and Sir Eyre Coote, 104

Jesuit Fathers, 160

Jews, 145

Jogīs, 184

Jurisprudence (Fiqh), 38, 62, 122, 193 :

Treatise on, by Emperor Bābar, 122

Jurists, 36, 38, 65, I93

KAIQUBĀD, Sultāan, deplorable effect of his example, 28-29

Kalīlah-Damnah:

A book of Indian tales, I 5

Translated into Pahlawi, Arabic, and Persian, 15

Kashmir, Kingdom of :

Husain Khān, builder and endower of colleges, 106

Zainul 'Ábidin, patron of letters and the arts, 105

Kathakas, 39

Khāndīsh, Kings of, 98-99, I 15

Khusrau, Amir :

'Ārizi-Mamālik under Sulțān Kaiqubād, 3 I

Honoured by Sulțān Jalāluddīn, 3 I

Imperial librarian at Delhi, 31

Keeper of the Qur'än, 3 I

Pensioned by 'Alāuddīn Khiljī, 36

Praises Delhi in verse, 28

President of the Prince's literary society, 24, 26

Taken prisoner in battle, 26

Tutor of Prince Muhammad, 24, 25

LANGUAGES :

Question of provision for their teaching at early colleges, 65

Scope and use of, among Muslims and Hindus, 76 (note)

Various, spoken in the harem of Fìrūz Shāh Bahmanī, 84 


\section{INDEX I}

Law :

Abū Hanifah, school of, 44

Code engraved on copper plates, 105-106

framed by Sulțān Ghiyāṣuddīn Tughlaq, 42

Studied by Sulțān Bahlūl, 72-73

Sulțān Muhammad Tughlaq's interest in, 44, 48

Value of the study to a monarch, 73

Lawyers, 48, 145

Learning, Hindu :

Disendowed and persecuted by Muhammadans, xlv.

Maintained by its own votaries under first Muslim rulers, xlvi.

Prince Dārā Shikūh's interest in, I 84-1 86

Studied by Muhammadan scholars, I 3, 64-65

Learning, Muhammadan, in India :

Centres of, not inferior to those outside India, I I 6

Credit due to efforts to promote, viii.

Decadence following 'Alāuddin Khiljī's reign, 43

Efforts to promote, this book a history of, viii.

Inferior in type to that of older Muslim centres, vii.

Not hitherto treated systematically, ix.

Paradoxical progress of, under a hater of learning, 39-40

Promotion of, more abidingly valuable than political conquest, vii.

Quality of, not the subject of this book, vii.

Librarians, 31, I 32, I 5 I (note), 175

Libraries, classification in, I 5 I-I 52

Libraries, Hindu :

Nagarkot Temple, 64

Old Hindu, looted by Muhammadans, xlvi.

Libraries, Muhammadan, I4, 20, 31, 37, 69, 87, 89, 90, 94, 96, I 12 , I 24, I 25, I 26, I 5 I, I 52, I 53, I70, I98, I99, 20I-202 :

Akbar's, I 5 I, I 52

Ghāzī Khān's, criticized by Bābar, 125-126

Imperial, at Delhi, I 52 (note), I98-I99

Life in a Muhammadan University, IO2-103

Literary parties of the Sulțāns, 30, 3 I, I 23

production, sumptuous, 69

societies in Delhi, 24

Literature, Arabic, enriched by Sanskrit and Greek studies, I 3

Greek, studied by Muhammadans, I 3

Literature, Hindu (Sanskrit) :

Independence of, under first Muhammadan rulers, xlvi. 


\section{INDEX I}

Literature, Hindu (Sanskrit)-continued.

Translated into Arabic and Persian under Maḥmūd and Mas'ūd, I 3

Persian under Akbar, I47-I 50

Fīrūz Shāh Tughlaq, 65, 70 (note)

Translations from, by Prince Dārā Shikūh, I 85

Literature, Persian :

Enriched by Sanskrit and Greek studies, 13

Kalīlah-Damnah translated into, I 5

Nașiruddīn, Sultān, a patron of, 23

Studied by Hindus under Sikandar, 75-76

Logic (Ușūli-Fiqh), 38, 44, 84, I62

Lectures on, before Fīrūz Shāh Bahmanī, 84

Muhammad Tughlaq's mastery of, 44

Order of its study at colleges, 162

Longimetry, $16 \mathrm{I}$

Madrasaus. See Colleges

Magicians, 90

Maḥmūd, Sulțān :

Alberuni, relations with, xvii., 13

Curiously rewards 'Unșurī, 7

Cuts off a woman's hair, 7

Founds University of Ghaznī, 5

Iconoclast and bigot, xiv., 3

Illiberal treatment of Firdausī, xiv., xvi., 9

Munificence, 4

Pacified by a poem, I I

Patronage of learned men, 3, 4, 5, 6, 7, I I

Ravages of, in India, 3

Traditions maintained by his son, I 2

Ugliness, 4

Zeal for education bequeathed to successors, I I

Maḥmūd Gāwān, patron of letters :

A learned and famous minister to Muhammad Shāh Bahmanī II., 86

Beneficence to literature and learning, 87

Builds a magnificent college at Bīdar, 87

His riches and self-sacrifice, 89

Literary work and poems, 87

Remains of his public works, 87

Victim of ungrateful master, xxiv.

Maḥmūd Shāh Bahmanī :

Accomplished and a poet, 82 


\section{INDEX I}

Maḥmūd Shāh Bahmani-continued.

Founds a college and schools for orphans, 82,83

Generosity to poets, 82,83

Renown as a patron of learning, 82

Styled Aristotle for his wisdom, 83

Maktab ceremony, the, I28, I4I

Mālwa, city of, a great literary resort, 97

Mālwa, Kingdom of :

Bāz Bahādur, Sulțān, loses his throne through over-devotion to music, 98

Ghiyāșuddīn, Sulțān (I469-I 500), appoints schoolmistresses to instruct the ladies of his harem, 97, 20I

Mahmūd Khiljī, Sulțān, great promoter of learning, founder of colleges and lover of history, 96-97

Mathematics :

Abstract, order in which studied at colleges, 162

Indian, studied by Muhammadans, 13

Text-books in, 8I (note)

Maulā, Sayyid :

Assassinated for treason, 32

Founds academy and almshouse at Delhi, 28, 32

Visited by Sulțān's son, 32

Mechanical art :

Akbar's encouragement of, 164

Automatic slot machine of Sayyid Husain Shirāzī, 165 (note)

Removal of massive monuments by Fìrūz Shāh Tughlaq, 52-53

Water-clock, xxiii., 55

Medicine :

Indian, studied by Muhammadans, 13,77

Indian work on, translated into Persian, 77

Muhammad Tughlaq, Sulțān, skilled in, 44

Meeting-rooms attached to tombs, 58 (note)

Memory, retentive, of Sulțān Muhạmmad Tughlaq, 44

Minstrels, 39

Mongols, 176

Monuments, Hindu, Sulțān Fīrūz Shhāh Tughlaq's respect for, 52

Morality, first science to be studied at Muslim colleges, I6I

Muḥammad Ghūūī, Sulțān :

Combines literary education with training in Government, I 8

Educates Turkish slaves, 18

Famous in warfare, 17

Founds college at Ajmere, I 8 


\section{INDEX I}

Muhammad, Prince, son of Sultān Balban :

Founder of literary societies, 24

Literary tastes, 24-25

Offers to learned men, 26

Patron of poets, 25

Premature death in war, 26

Muhammad Shah, Emperor:

Friend to astronomy, 196-197

Imperial Library pillaged by Nādir Shhāh, 198

Sack of Delhi ordered by Nādir Shāh from a college, 197-198

Muhammad Shāh Bahmanī II. :

Education and learning, 86

Maḥmūd Gāwān, his famous minister, 86-89

Muhammad Tughlaq, Sulțān :

Accomplished and erudite, 43,44

Irascible and cruel, xxii., 45

Literary splendour of his court, 48

Munificent at first to scholars, 45,48

Whimsical, $43,45,46$

Muhammadan invasions of India :

Mark beginning of momentous changes, xlv.

Transfer State patronage from non-Islāmic to Islāmic learning, xlvi.

Muhammadans (Muslims, Musalmāns), 36, 40, 64, 65, 76, 94, I06, 107, I13, 126, 1 57, 168, 17 I, 172, 205

Co-education of, with Hindus, 160

Intermix with Hindus, 40

Learn Hindu languages, 64

Multān, Kingdom of :

Husain Langāa, learned king and builder of colleges, 105

Music :

Multān compared with Gujrāt, I05

Akbar's encouragement of, 155,157

Cultivation of, under Akbar, 158

Dhrupad, I 58

Hindu and Muhammadan, intermixture of, I 57

Khiyäl, 157

Royal proficiency in, 92, 93, 98, 122, 183

Splendour of, in Akbar's time, I 57

Studied privately, 117

Treatise on, by Emperor Bābar, 122

Treatises on, written in Kashmīr, 105

Musical instruments and famous players, $156-157$

Musicians, 24, 39, 54, 92, 93, 98, I 56-1 57, I 83

Royal patronage of, 92, I 55-157, 183 


\section{INDEX I}

Musicians and singers classed as "People of Pleasure" (Ahli Murād), 129

Mutașaddīs (Scribes), I 74

Muz̃affar Shāh II., of Gujrāt, a royal Mæcenas, I06

NAṢ̄̄RUdDīn, Sulțān :

Expert penman, 22

Patron of Persian literature, 23

Student and hermit, 22

Nūr Jahān, wife of Jahāngīr, a learned woman and a capable administratrix, 202

OBSERVATORIES, 15, 125, 196-197

Orphans, institutions for, $45,82,83$

PAINTERS :

Eminent, at Akbar's court, 154

Patronage of, by Sultāns, 92, I 54, I76, I 83

Painting :

'Âdil Shāh's skill in, 93

Akbar's encouragement of, I 53-I 55

Animal, 126, 178

Excellence of, in Jahāngīir's time, I77

Painting gallery, Akbar's, I 54

Persian, influence on Indian painting, 126

Portraits of Akbar's court officials, I 55 tabooed by Fìrūz Shāh Tughlaq, 54

Studied privately, I I 7

Styles of, under the Mughal Dynasty, 183

Paper :

Chinese inferior to European, 96

Manufactured at Siyālkūț, I90

Paṭhān Dynasty:

Tribute to its services to learning, I I4-I I 5

Triumphant in peace as well as war, I 14

Pens, reed, used at Muslim schools, 96

Persian language :

Difficulty of reading, xxi.

Kalìlah-Damnah translated into, 15

Knowledge of, necessary to Government officials, 64

Known to learned Hindus, $64-65,76$

Mastery of, by Sulțān Muhammad Tughlaq, 44

Studied by Sulțān 'Alāuddīn Khiljī, 33

Studied first by Hindus under Sultān Sikandar, 75-76 


\section{INDEX I}

Persian language-continued.

Taught at Nishāpūr, I9

Teaching, improved methods of, under Akbar, I6I

Translations into, from Turkish, Kashmirian and Arabic, in Akbar's reign, 149-I 50

Translations of Indian works into, 13-14, 65, 147, 148, I 49, I 50

Pharmacology, Indian, studied by Muhammadans, 13

Philosophers, 27, 36, 65, 97, 144

Philosophy :

Greek, studied by Muhammad Tughlaq, 44

Indian, studied by Muhammadans, 13

Muhammadan, studied zealously under 'Alāuddin Khiljī, 37

Natural, order of its study at Muslim colleges, I62

Physic, 162

Physicians, 39,48

Pigeon-flying, tutor of Akbar dismissed for, $\mathrm{I}_{42}$

Poetesses, 202

Poetry :

Pacific effect of, on Sulțān Mahmü̃d, I I

Proficiency in, by Sultạn Muhammad Tughlaq, 44

Poets, 6, 7, 8, 9, 20, 24, 26, 36, 48, 65, 73, 82, 84, 87, 92, 93, 107, 108, 1 22, 128, 168, 169, 179, 180, 204

Poets, royal rewards to, $6,7,9$, I0, I I, 82,83, I 83 (note)

Portrait Painting :

Forbidden by Fīrūz Shāh Tughlaq, 54

Permitted by Akbar, I 55

Precedence, problem of, Akbar's solution, I44

Pretender to learning, a successful, 85-86

Private Benefactors of Learning :

'Abdul Rahīm, Khāan Khānān, I69-I70

Akramuddin Khān Șadr, I88-189

Assadullāh of Birbhum, II 2

Biānah, lords of, 37

Gardiz, noblemen of, 37

Ghāzīuddīn, 194

Hasan Razā Khān, I99

Janjar family, 37

Khān Fìrūz Jang, 194

Māham Anaga, I65

Maḥmūd Gāwān of Bīdar, 86-89, I I6

Mas'ūd 'Alì Husain Khān, 78

Maulā, Sayyid, 27, 28, 32

Muḥammad Walì-ullāh, 196 


\section{INDEX I}

Private Benefactors of Learning-continued.

Nauhattah, nobles of, 37

Rafi'uddin Muhammad, Qāạī, 189:

Zainuddīn Khāin, Shaikh, I 34

Private tuition :

A means for special and advanced instruction, 117,164

Prevalence and scope of, I 17

Text-books used by son of $\mathrm{Da}^{\prime} \mathbf{u} \mathrm{d}$ Shāh, 8I (note)

Private tuition, instances of :

'Abdul Qādir studies with Mīhr 'Alī Beg, I64

'Aläuddīn Khiljī's private studies, 33

Ishāâ, Maulānā, as preceptor, I 17

Prosody, Emperor Bābar's treatise on, 122

Public Works Department (Shurati 'Ām), literary duties of I 26-127

Qulis, a forest tribe, 132

Quțbuddin, Sulțān, ruthless enemy to Hindu religion and learning, 19-20

RANK of learned men, next to royalty and governors, I30

Raziyah, Sulțāna, a gifted woman-ruler and friend to learning, xviii., xxviii., $21-22,201$

Reading, difficulty of, in mediæval times, xxi.

improved method of teaching, introduced under Akbar, I6I

Reciters, 90,98

Recluses, 179

References and allusions, value of, in historical research, ix.

Relations of Hindus with Muhammadans, 40, 64, 65, 94, II 3, I 57, I7 I, I72

Religion, Akbar's catholic attitude to, 145, 146

Religions, equality of, Kabir's doctrine, 74 various, represented at Akbar's assemblies, 145

Reservoir of 'Alāuddin Khiljī (Hauz Khāṣ), 60 (note)

Rhetoric, text-book of, $8 \mathrm{I}$ (note)

ȘADRI-JAHĀN (a Muslim official), 48

Sannyāsīs, I 84

Sanskrit :

Cherished language of the Hindus, 76 (note)

Prince Dārā Sh̆ikūh's proficiency in, 184

Translations from, into Persian by order of Akbar, 147-I 50

Sayyids (descendants of the Prophet), I44 


\section{INDEX I}

Scholars :

Buddhist, massacre of, at Bihār, 20

Hindu and Buddhist persecuted by Muhammadans, xlvi.

Islāmic, inferior in India to those outside, vii. royal generosity to, $4,12,13$

Tīmūr's opinion of their courage, 68

Schools :

Agra, in memory of Shaikh Zainuddīn Khāiī, I 34

Delhi, Sayyid Maulā's academy, 28

Fatḥpūr Sīkrī, houses of Abul Faẓl and Faizịi, 152 (note)

Founded by Mas'ūd, 12

Musalmān Primary, in South India, 96

Nishāpūr, 19

Repaired by Fīrūz Shāh Tughlaq, 56

Silāpūr, for Hindus and Muhammadans, I I 3

Science, royal patrons of, 77, 104, 196

Sciences, order of teaching, in Akbar's time, 16I-162

Seven Halls of Audience, Humāyūn's, I 3 I

Shah 'Âlam II., Emperor :

College founded at Farrukhābād, 199

New Imperial Library pillaged by Ghulām Qādir, 198

Shāh Beg Arghūn, of Sindh, great promoter of letters, I05

Shāh Jahān, Emperor :

Encourages music, painting, and learning, I 83

Founder of Imperial College, Delhi, I 8 I

Jahānārā Begam, his eldest daughter, 203-204

Magnificent buildings a main feature of his reign, I80

Maintains educational progress, I 8 I

Nightly studies, 182

Patron of history, 183

Repairs college buildings, 182

Shaikhs, 42, 67, I37, I44, I75, I78

Shi'as, 145

Shīr Shāh, Emperor :

A great prince in spite of his perfidies, xxvi.

A neglected child and self-made man, 136

Lover of history and poetry and the company of scholars, 137

Madrasah built by him at Nārnaul, I 37

Sikandar Lūdī, Sulțān :

Bigotry of, 74

Conquers Jaunpür and destroys its colleges, IOI

Cruelly terminates a religious argument, $74-75$

Encourages learning and belles lettres, $73,77-78$

Fond of religious disputation, 74 


\section{INDEX I}

Sikandar Lūdi, Sulțān-contimued.

Founds a college at Narwār, 74

Makes verses under a pen-name, 73

Midnight repasts of, $76-77$

Pioneer of literary education of military men, 73-74

Turns Hindu temples into Muslim colleges, 74

Singers, famous, $31,155,156,178,183$

Sivaliks, fossils of, xxiii.

Siyālkūt (Sealkot), famous seat of learning and of the paper manufacture, I89-190

Slave Dynasty (Qutbuddin, a slave, and his successors), 19-29

Slaves educated by Sulțāns, I 8,54

State encouragement of learning :

Edict of Fīrūz Shāh Tughlaq, 56

Emperor's literary tastes reflected by his court and serving as a barometer of the literary atmosphere, xlvi.-xlvii.

Exception proving this rule, xlvii.

Importance of observing the literary tastes, etc., of Muhammadan rulers, xlviii.

Story-tellers (Qișșāhgus), 24, 54, 90

Subjects taught:

At Fīrüz-Shāhi-Madrasah, 62

Nishāpūr, 19

By a I4th-century tutor, 8I (note)

In Akbar's time, $161-162$

Șūfïism, I 52, I 85

Sưfiss, 62, 144, 185

Sunnīs, 145

TAFsīrs (Commentaries on the Qur'än), 38, 176, 193

Tartar language, I90

Țāsi-gharỵāl at Fīrūzābād, xxiii., 55

Tazkirs, performers of, 39

Theologians, 38, 75, 108:

Disputation under Sikandar Lūdī, 74-75

Qur'àn specialists, 38, 39, 62

Theology :

Hindu, studied by Prince Dārā Shikūh, I 84 -1 85

Muhammadan, instance of rigid study of, under Sikandar, 78

Tìmür Beg, Emperor : studied zealously under 'Alāuddīn Khiljī, 37 text-book of, $8 \mathbf{I}$ (note)

Autobiography, 67

Conquest of India, 67 


\section{INDEX I}

Tīmūr Beg, Emperor-continued.

Early education, 68

Founds a college, academies, and libraries, 69

Respect for learning, 67

Tomb in his college at Samarqand, 69

Timurides, 126,176

Tombs, 36, 58, 59, 6I (note), 66, 69, I09, I 34, I 38, 194, 203

Transliteration, Table of, xxix.

Transportation of massive columns, how effected, 53

Turkī language, $x x v .-x x v i ., 122$

Turkish language, 76 (note), I22, I23, I 50, 174

UNIVERSITIES :

Bihār, destroyed by Bakhhtiyār, 19-20

Ghaznī, founded by Maḥmūd, 5

Old Hindu, broken up by Muhammadans, xlvi.

Rise of, under 'Alāuddīn Khiljī, 35

Universities, Muslim, etc. :

Azhar, at Cairo, 102 (note)

Expenses of students met by letting apartments, IO2

Government aid to, 103

Inspection of, from Delhi, 103

Jaunpūr, 102-105

University life in Jaunpūr, 102-103

'Unșurī :

Censor of literature, 5,7

Greatest poet of his age, 5, 6

Panegyrist of Mahmūd, 6

Poet-laureate, 7

Professor at Ghaznī, 5, 7

Urdu (Hindustani language), origin of, 75-76

Veterinary art, Hindu works on, translated into Persian, 70 (note)

WĀQI'NAVīs, or court diarists, I 5 I

Wards of Hindu cities called after days of the week, I 3 I (note)

Water-clock, invention of, xxiii.

Patronage of by Fīrūz Shäh Tughlaq, 55

Weight in silver, a poet's, 183 (note)

Whims, a sulțān's, 45-47

White garments, Muhammadan honour of wearing, 3 I 


\section{INDEX I}

Women, learned, instances of :

Badrunnisā, third daughter of Aurangzib, 204

Chānd Bībī, xxviii.

Durgāvatī, xxviii.

Gul-Badan Begam, daughter of Bābar, 201

Jahānārā Begam, daughter of Shāh Jahān, xxvii., 203-204

Māham Anaga, Akbar's wet-nurse, 165, 167-168, 202

Māh Malik, xxviii.

Mumtaz Mahal, wife of Shāh Jahān, poetess, 202

Nūr Jahān, wife of Jahāngīr, 202

Raziyah, Sulțāna, daughter and successor to Altamash, xviii., xxviii., 21, 22, 201

Salima Sulțāna, niece of Humāyūn, poetess, xxvii., 202

Sattiunnisā, learned governess of Jahānārā Begam, 204

Zỉbunnisā Begam, eldest daughter of Aurangzib, taught by her father, xxvii., 204

Women recite the $Q u r^{\prime} \bar{a} n$ to Sultāan Ghiyāṣuddin of Mālwa, 98

Women-Rulers :

Rażiyah, Sulțāna, xviii., xxviii., 21-22, 201

Nür Jahān, wife of Jahāngīr, 202

Wrestling-schools founded in Ahmadnagar. 95

Writing materials, 96

Writing, styles of, I 23, I 58-1 59

ZEMINDAR, a liberal, I I2

Zỉbunnisā Begam, cultured daughter of Aurangzib and patroness of learning, 204

Zoroastrians, 145 


\section{INDEX II.-PROPER NAMES AND LITERARY REFERENCES}

'Abdul Aḥad, Maulawī, x.

- 'Aziz, 48 Hakim, 36

I83 (note)

Siyālkūṭī, Mullā, I79,

- Haqq, Shaikh, I63

—Dihlawī, I78

- Haqqī, 43

- Hasan Kambū, Shaikh, I 38

- Karìm Sindī, Mullā, 87

— Ilyās, Miyān, 75

— Muktādir Shanihī, Qāzì, 65 179

Mutțālib Sulțānpürī, Mullā,

- Nabì Dihlawi, Shaikh, I69 I64. I72

'Abdul-Rahīim, Maulānā, 159

- Mirzà, 160, I69. I70, 173

'Abdul Raḥmān, Miyān, 75

I79 Bhurah Gujrātī, Mullā,

- Salìm, Maulānā, I 84

— Wahīe Khairābādī, 199

— Walì, Kh̆ān Șāhib, x.

'Abdulhayy, Maulānā, I 59

'Abdullāh, 76, 77

—, Maulawī, I89

- Sulțānpurī, Maulānā, I45, 169

Shaikh I38

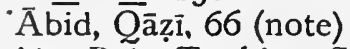

Abū Bakr Tughhlaq, Sulțān, 67
Abū Hanīfah, I2, 44 Muhammad Nasāhī, 12 Rihàn, xvii., I 2

Abul 'Abbās, 44

- Fazl, Shaikh, xxii., xxiii., I22, I24, I4I, I43, I45, I46, I48, I 50, I $5 \mathrm{I}, 158,160,16 \mathrm{I}$, $162,169,172$

- Hasan, I76, I 77

'Ādil Shhāh, King of Bījāpūr, 92, 93

Afghanistan, xiv., xv.

Agra, xv., 72, 73, 78, I 16, i 24 ,

I 34, I 63, I64, I 75

Agra Fort, I 53

Aḥmad, Sayyid, I 81

Aḥmad bin Hasan Maimandī, 9

- Khān, Sayyid, 66

— Nizām Shāh, King of Aḥmadnagar, 94-95

- T'hat'hah, Mullā, I49

- T'hat'hahwī, Maulānā, 15 I

Thānīsvarī, Maulānā, 65

Aḥmadābād, I70, I 88

Ahmadnagar, 90, 94, 95

A hisan, Sayyid, 75

$\overline{A^{\prime}}$ ini-Akbari, xxii., $\mathrm{xxiii.,} 68$ (note)

'A'īnul-Mulk, 66

'A'inul-Mulkì, 66

'Āishah, 205

A'izzuddin Khalid Khānī, 65

Ajalī, Sayyid, 37

Ajmere, 18, 162

Ajmere Gate, 194 


\section{INDEX II}

- Rajah of, xviii.

Akbar the Great, Emperor, xiv., xix., xx., xxi., xxii., xxvi., $49,98,102,121,132,139-172$, $173,175,187,189,202$ Akbar-Nämah, 124, 201

Akḍāā, 109

Akh̀lāq-i-Nāsirī, I 43

Akramuddīn Khān Șadr, I88, 189

'Alā'ì, Shaikh, 138

'Ālamgīr, 193

'Alāuddin Áttar, 184

I7

Ghūrī, Sulțān, xv., xxviii.,

- Hindī, Mullā, 169

Kark, Maulānā, 38

Khiljī, Sultāan, xviii., xix., xx., xxi., xxii., xlvii., 32, 33 . $34,36,39,40,43,58,59$, II 4 , I 16,171

—— Lāhaurī, Maulānā, 38 - Maqrī, 39

- Șadr-ul-Shami'ah, Maulānā, 38

- Tajr, Maulānā, 58

Alberuni, xvii., I 3

Alberuni's Canon Masudicus, xvii.

Alexander the Great, 64

'Alī Aḥmmad Nishhānī, Maulānā, IOO

Beg, Mullā, 68

Chaman Kashmirī, I 59

Ibrāhīm Khān, I I 2

'Alī Janjar, 37

'Ālim Andapathī, Maulānā, 65

'Ālimuddīn (physician), 39

—, Maulānā, 39

- Maulawī, 195

'Alīwardī Khān, II 2

Allāhdād Șālih, Mullā, 75

Allāhdādī, Miyān, 75

Altamash, Sultāan, 20, 21, 201

Amān, Sayyid, 75

Amber, Rājā of, 196
A'mī A'marī, I79

Amir 'Ali Shir, I 22

- Arslān, 39

- Arsalān Qulī, 30

— Fathuullāh Shìrāzì, 150

- Hasan, 25, 36

- Khașșah, 3 I

- Khusrau, 24, 25, 26, 28, 30,

$31,36,124$

- Kūhāāni, 20

Anhilpūr, Rājā of, 40

Anwar Khān Khwãrizmī (Abũ

Rihān), xvii., I2

Anwari-Suhaili, I 5

Anwarul-Mishkāt, I 52

Arabia, I 1, 77, 82, 106

Argar-mahābedak, 77

Argar-mahābedak, 77

'Ārif, Maulānā, 36

- of Ghazni, 27

Asadī TTu ūsī, 6

Asadullāh, I I 2

Asadul Zaman Khān Gauhar, Maulāwĩ, xi.

'Āṣaf Jāh, I94

- Khān, 151

Āșafuddaulah, 199

- Nawāb, IO3

Āsāpūr (pergana), 106

Āșāri Mahal, 94

Ashraf Khān, I 59

Asiatic Society of Bengal, $x$.

Așjudī 7, 8

Asthipura, 109

Atharva Veda, 148

Aurangzib, Emperor, xxii., xxvii., 88, 94, I21, I86, I87193, 194, 204

'Awärif, 37

Ayār-Dänish (Pañchatantra), 149, I53

'Azamuddīn, Maulānā, I4I, 142

'Azzimābād, I I 2

'Azīzullā, Miyān, 75

'Azuududdīn, 48 


\section{INDEX II}

BĀBĀ Lāl Dās, I 86

- Țālib Ișpahānī, 179

Bābar, Emperor, xv., xvi., xxiv., xxv., xxvi., xxvii., I2I-I27, I 51,201

-, Memoirs of (Wäqi'āti -Bābari), xv., xvi., xxiv., xxvi., 122, 123, 124, 125, 126, 149, I 50, I 74, I 82

Badakshan, $I 70$

Badā'ūn, 7I, I I6

Badā'ūnī, xxvi., xxvii.

Badà'.ün ì, xviii., xxvii., 68, I 38

Badruddin, Shaikh, 27

— Damash̆ì, Maulānā, 39

$B \bar{a} d s h \bar{a} h-N \bar{a} m a h$, I 56

Bagh̆dād, vii., 38, 46, I02 (note), I04, I 16

-, Caliph of, 2 r

Bahādur Shāh, I94-I96

Bahäristān, ro

Bahāuddīn, Shaikh, 27

Bahlūl, Sulțān, 71, 72, 73

Qādirī, Shaikh, I 84

Bahmani, kingdom of, 80-9I,

I 5

- Ahmad Shhāh, 86

—, Fìrūz Shāhh, 84-86, I I 5

- Ghiyāsuddīn Shāh, 83

- Hasan Gangu, 81

- Mahmūd Shāh, 82-83

- - - II., 89-90

—, Muhammad Shhāh II., 8689

—, Mujāhid Sh̆āh, 8I

- Shamsuddīn Shāh, 83

Bahrām Qulī of Hirāt, I 57

Bairām, Sulțān (Slave Dynasty),

22

— bin Mas'ūd, Sulțān, I4-I 5
Khān (guardian of Akbar),
I4I, I69, I70, 202

Bakhtiyār Khiljī, 19, 20, 106

Balban, Sulțān, 23, 26, 27, 28, I I 5

Balkh, 6, 169
Baqā'î, Maulānā, I27

Baqar, Kashmīiñ, Mullā, r79

- Tuhta'ì, Mullā, 179

Bāqī Khațîr, 30

Bāqir, Maulānā, 159

Barnī, Ziyāuddīn, xx., 34, 38, $39,46,48,51,60,62$ (note), 63

Basakat, Sayyid, 69

Basāwan, 154

Basāwar, I64

Basu, Mālādhar, Io9

Bațlmīūs, I 25

Bawal, I 37

Bāyazīd, Maulānā, I42

Bāz Bahādur (Lāla Beg), King of Mālwa, 98, r 32, 158

Bazar-i-Bazzāzān, 22

Beale, xxiv.

Benares, 103, 104, 185, 196

Bengal, x., xvi., 20, 27, I06, I07, 108, I I 3, I 24

Bernier, I 80, I 8I, 192

Beveridge, H., F.A.S.B., x., xiii.xxviii., I4I (note)

Bhāgavadgītā, I 85

Bhāgavata Purāna, Io9

Bhima, 52

Bhudh, Miyān, 77

Biānah, 37, I 89

Bībī, mother of Fīrūz Shāh

Tughlaq, xxii. Rājī, IOI

Bichitr Khān, I 56

Bīdar, $83,87,88$ (note), I I 6

Bihār, I9, 20

Bihrūz, 3 I

Bihzād, Ustād, I 32 (note), I76

Bījāpūr, 86, 91, 92, 94

Bilās, I 56

Bīr Maṇdal Khān, I 56

Birbhum, I I 2

Blochmann's $\bar{A}^{\prime}$ inni-Akbarī, 68 (note)

Bohār Collection, $\mathrm{x}$.

Bologna, 6

Bolt Court, xxi. 


\section{INDEX II}

Bombay, xvii.

Briggs, xvii., xix.

Bryce, Lord, xviii.

Budhan, 74

Bukhārā, 20, 28, 38, 77, I I6

Buǩnārī Gujrātī, Sayyid, 183

Būmì-Salìm-Nāmah, 44

Burhān, Sayyid, 75

Burhānuddīn, 48, 98

—— Bhakrī, Maulānā, 38

Burhānpūr, 98

Burton, xxviii.

Bustān (Sa'dì's), 8 I, I 37, I43

Būtkhāk, xiv.

Buzurchimihr, 15

CAIro, vii., 38, 46, 102 (note), I04, I 16

Calcutta, xiii.

Imperial Library, $\mathbf{x}$.

Cambay, I 32

Catrou, 177

Chāghtā'ì. Sayyid Khān, I60

Chahār Minār, 95

Chatar Khān, I78

Chalukya Dynasty, 9I

Chānd, Miyān, 156

— Khān, I 56

— Bïbī, xxviii.

- Shaikh, 97

Chand $\bar{\imath}$-Màngal, 168

Changīz Khăn, 20, 23, 68, 12 I

Changiz-Nämah, I 53

Chatterji, Ramananda, M.A., $\mathrm{xi}$.

Chaul, 83,85

Chesterfield, Lord, xvi., xvii.

Chhuṭi Khān, I IO, I I I

China, 96

Chinhar (Chunhar), I 34

Chistī, 204

Chitor, 97

Chittagong, I I I

Condé, the Great, xiv.

Coote, Sir Eyre, I04

Cordova, vii., IO2 (note), 104
Crillon, xvi.

Cuttair, 7 I

DabuL, 83

Dalāili-Fìrüz-Shāhī, 65

Damascus, 38, IO2 (note), II6

Damayantĩ, I 49

Dāniyāl, I60

Daqiqī, 8

Dārā Shikūh, Prince, I84-I 86

Darasbārī, 108

Dār-ul-Baqā, I 82

Daswant, I 54

Dā'ūd Ḍhārī, I 56

Daulatăbād (Deogir), xxiii., 45, $46,47,49,83,85,98$

Daurī, Maulānā, I 59

Dāwan Dḥāri, Shaıkh, I 56

Deccan, xxiv., $82,83,87$, 91, I94

De Courteille, xxv., xxvi.

Delhi, xxii., xxiii., 20, 22, 23, 24 , $25,27,28,3$ I $32,34,35,36$, $37,38,39,42,43,46,47,48$, $49,54,58,63,67,70,71,73$, $75,80,90,100,116,124,126$, I 33, I63, I67, I8I, I94, 195, 196, 197, 198, 202

$\longrightarrow$ New, I 34

Delhi Past and Present, Fanshawe's, 42

Dewal Devī, 40

Dey, Kumud Lal, xi.

, Nundolal, M.A., B.L., $x$.

Dilshād, aunt of Ismāî̀ 'Âdil Shhāh, 93

Dimashq, vii., 104

Dipalpūr, xxii.

Dizwān of Anwarī, I43

Dīwāni-Khāqāni, 25, I43

Dïwāni-Sanā'i, 25

Dost, Ustā, 156

Duncan, Mr., IO4

Dürer, I 77 (note)

Durgavatī, xxviii. 


\section{INDEX II}

ELLICHPŪR, 83

Elliot, J. H., x.

Elliot's History of India, xx.; xxiii.

Elphinstone, xviii., xxi.

Erskine, Mr., xxv., I 2 I

Europe, xvii., 96, 146, 195

FAIZĩ, Shaikh. I48, I 52, I60, I 72, 185

Fakhruddīn Hānsūī, Maulānā, 38

— Khawāṣ, 36

- Kutwāl, 27

Naqlāh, Qāzị, 38

Shaqāqil, Maulānā, 38

Fakhrul-Marābi', I95

Fakhr-ul-Mulk, 2 I

Rub’ul Mafākhir, I95

Fanshawe, 42

Farīd (Shīr Shäh), 99, I 36

Farrukh Beg, I76

- the Qalmāq, I 54

Farrukhābād, 196, 199

Farrukhī 7, 8

Fasūnī Kāshīi, I 80

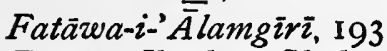

Fatāwa-Ibrāhīm-Shāhn̄, 100

Fath Khān, 59

Fath-Nāmahs, 39

Fatḥpūr Sīkrī, I44, 162, I67

Fāțimah, 205

Fāzil Kābulī, Mullā, I79

Feni, I Io

Fergusson, Mr., 91, 94

Ferishta, xvii., xix., xx., xxiv., xxviii., 5, IO, I I, I4, I 8, 2 I, 34, $35,36,56,76,81,88,90,97$

Firdausī, xiv., xvi., $6,8,9$, Io

Firinghi Mahal, Lucknow, I 88

Fīrūz Shāh Tughlaq, Sulțān, xxii., xxiii., 42, 46, 47, 49-66, $69,80,84$, IOO, IOI, IO4, I I4, I 77,164, I 7 I

Fīrūz-Shhāhī-Madrasah, 60-63, 64
Fīrūzābād, 47, 49, 51, 52, 53, 60, $70,71,73,116$

Fleet, Mr., xxiii.

Futūhāa, 3 I

Futūhăati-Fìrīz-Shāhì, 50

Gangādhar, 150

Gardiz, 37

Gaur, xvi.

Ghauss-ul-Șaqalin, 78

Ghāzī Khẳn, 125

Ghāzīuddin, 194, 195

Ghaznī, xv., xvi., xvii., 3, 5, 6, 7, $8,12,17,18$

- , House of, xiii., 3, I I, I4, I6, I7

Ghiyāsuddīn, Governor of Bengal, 106

-, King of Mälwa, 97

- II., of Bengal, 107, 108

— II., Sulțān, 67

- Jamshïd, 125 Tugh̆laq, Sulțān, 42, 50

Ghulām Husain, I Io

— Qādir, 198

Ghūr, House of, xviii., I7-18, 19

Ğhūrāsh

Gibb Trust, xxv.

Goa, 85, I46, 178

Gond country, xxviii.

Gospel (Christian), 146, I 50

Gour, IO9, I IO

Gujrāt, I05, I 24, 152, 163 (note), I75, I 76, I88, I89

Gul-Badan Begam, 201

Gulbargah, 83, 86

Gulistān, 1 37, I43

Gulkandah Dynasty, 95, I I 5

Gul-Rukh, 202

Gulrukh (pen-name of Sulțān Sikandar), 73

Gwalior, 10, I 55, I 56

HAB $\bar{I} B U L-S I Y A R, 123$

Hadĩgah, I43

ḦHadīqatul-Aqālīm, I05 


\section{INDEX II}

Hāafiz, $69,82,83,108,142,165$ (note)

- Nazīir Aḥmad, Maulawī, x. T⿳亠̄shquandī, I69

Haibat $\overline{K h} \bar{a} n, 178$

Haidar 'Ali, xx. Khașālī, Mullā, I80

Haidarābād, xxiv., 95, 96, I 16

Hakīm Husain Gịlānī, 85 Sanā'ì, I 43

Halākū Khān (İlkhāni), I 25

Hamda, 204

Hamdullah Muṣtaufī, 4

Hamid, Maulānā, 39

Hamid Rājah, 3 I

Hamiduddin of Nagore, 108

— Baniānī, Maulānā, 38

- Mukhlas, Maulānā, 38

— Rājah, 36

Hamzah, 178

Hardwar, 67

Haribans', I 55

Haribansa, I 49

Hari Dās, 155

Hārūn-al-Rashīd, Caliph, I 5

Hasan, father of Shīir Shāh, I36

Hasan Farāghīi Gujrātī, Mullā, 178

- Ghaznawi, Sayyid, I 5 Naqshī, Maulānā, Ioo

Nizāmīi, I 8

—— Razā Kh Khān, 199

- Sive, I 37-1 38

Hasanat-ul-'Ärifin, I 86

Hashim, Sultān of Mashhad, I 57

Hā shiya $\overline{-}-H i n d \bar{\imath}, 137$

Hastings, Warren, 104

Hauz Khāș, 60-6I (note), 66

Havell, E. B., I 53

Hayātī Gīlānī, Mullā, I79

Hayātul-Haizwān, I 50

Ḣazrat Ishān, xxiv.

Hidäyah, 44

Hind, 77
Hindustan, xxv., 36, 71, 99, 102, I 24, 125, I 39, 161, 173, I 80

Hirāt, 123, 124, 1 57, I73

Hirwī, Shaikh, I 84

Hiṣn-i-Ḥașin, 78

Hissar, 137

Hujat Multānī Qadīm, Maulānā, 38

Hulwān, 170

Humāyūn, Emperor, xxvi., I02, 124, 126-135, I40, 142 , 167

Humāyūn-Nāmah, 201

Husain, Shaikh, 134

-, Sulțān of Hirāt, 124

- Gujrātī, Mullā, I79

Khāan (scholar), I 12

- (Wali of Kashmir), 106

—_ Langā, King of Multān, 105

Mīrzā Khwārizmī, Sulțān, I 5

- Shāh, Emperor of Bengal, 109-I 10

- Sharqī, King of Jaunpūr, 104, I 58 Shirāzī, Sayyid, I65 (note) $\bar{W} \bar{a}$ iż, Maulānā, I49 Kāshifī, Maulānā, I 5

Husāmuddīn ibn Shādī, Maulānā, 38

Surkh, Maulānā, 38

H.ūshang, Sulțān, 97

'IBĀDAT Khāna, I44-147, I 7 I

Ibn 'Alī Muhammad Koshjī, 125 (note)

- Bațuțah, xxii., 23, 46

- Khaldūn, 69

Ibn-ul-Muqliyā, 15

Ibni-Muqlah, 158

Ibrāhìm, Emperor, 125

$\longrightarrow$, Hājīi, I45

—, Sultānn, I4 


\section{INDEX II}

Ibrāhīm 'Ādil Shhāh I., of Bĩjāpūr, 93

94

Sarhindī, Hāàjī, I48

- Sharqī, King of Jaunpūr, 99, 100, IOI, 102, 104

'Ibrat-Nämah, 198

'Id-i-Āẓ̂̄ā, 23

Iftikhāruddīn Rāzī, Maulānā, 38

一 Q Qāzìi, 38

Ihya-ul-'Ulüm, 37, 193

I khhtiyāruddin Y Yàghì, 30

Ilāhābād, IO2

Ilāhdād Jaunpūrī, Maulānā Shaikh, 100

Ilāhī Bakhshsh-al-Husainī, I 10

Ilāj Khān, IO4

Ilminsky, $x x v$.

'Imāduddīn Hasan, Maulānā, 39

Imām Muhạmmad Ghazzāli, I9I

—_ Yūsuf Sajāwandī, I4

Imāmuddīn, Maulānā, I49 (note)

Iqbal-Nämah, 140, 153, 178

Iqbal-Nāmah-i-Fahāngīrī, 179

'İāq, 87

Irk, Fort, I75 (note)

Irsh $\bar{\alpha} d, 100$

Isḥāq Dḥārīi, I 56 Sarhindī, Mullā, 85

Ismā'îl 'Ádil Shāh, King of Bījāpūr, 93

Ispahān, 38

I'timād Khān Gujrātī, I 52

JA'FAR BEG, I 5 I

Sharīf, 200

Jagan, 154

Jahānāră Begam, xxvii., 203-204

Jahāngīr, Emperor, xix., xxvi., I03, I 26, I 39, 140, I42 (note), I 5I, I 73-I 80,202

Jahāngīr Mīrzā, 69

Fahāngìr-Nāmah, I 26, 140, I77, I 78

Jahāngīrdād, 178
Jahjū, Sayyid, 37

Jaipūr, I 53 (note), I96

Jai Singh, Sewai, Rājā of Amber, 196, 197

Jalāl Janjar, 37

Jalāluddīn, Sulțān, 30, 3I, 32, I67 (note)

- Hindīi, Qāzịi, I69

- Rūmī, Maulānā, 62

Jalandhar, 23

Jamāl, Governor of Jaunpūr, 136

—, Shaikh, 73

- Janjar, 37

Jamāluddīn Husain Injīr, xxvi.xxvii.

- Sayyid, 183

- Shățbī, 39

$\mathcal{F} \bar{a} m-i-\mathcal{F} \bar{a} m, 143$

Jāmì, II 7, I 43

- 'Abdul Raḥmān, Maulānā,

87

Fāmi'ul-Hikāyāt, 14

Fāmi' 'ul-Rashîdì, 149

Fāmi' 'ul-Tawārīkh, 68

Janjar, 37

Jarrett, xxii., xxiii.

Jauhar, 132

Jaunān, xxiii.

Jaunpūr, xxiii.-xxiv., 99, |IOI, 102, 103, 104, I I 5, I 16, I 36

Jaypūr, I 37

Joan of Arc, xv.

Fog-Väsishtha Rāmäyana, 185

Johnson, Samuel, xvi., xvii., xxi.

Jubbalpūr, I75 (note)

Jumna, I 34

Jüna or Jona, xxiii.

Jupiter, I 29, I 3 I

Juwaini Tabīb, 39

Jwaālāmukhi, ${ }^{64}$, I 7 I

$\mathrm{KAB \overline {R }}, 74$

Kabiiruddīn, 39

Kabul, xv.

Kafiyāh, I 37 


\section{INDEX II}

Kaiqubād, Sulțān, 28, 3I, 40

Kairawān, I04

Kālañjar, I I

Kalīlah-Damnah tra), I 5, I49, I 53

Kalyān, 9 I

Kamāluddīn, Qāzịi, 23

K, Kolī, Maulānā, 38

Kāmrān, I26

Kari (pergana), r89

Karīmuddīn Jauharī, Maulānā, 38

Kashf-ul-mahjūb, 37

Kashmīr, 105, I06, I49, I 58, I68, $1 \overline{8} 5$

, History of, 149

Kashshāf, I88

Keene, Mr., I 87

Kesū, I 54

Khairuddīn Rūmī, Maulānā, I 70

Khalīf Māmūn, I25

Khamsah, 25

Khān Fīrūz Jang, 194

Khān Khānān (Akbar's guardian), I4I, I 55, I69, I70, 202

- - (Bahmanī), 85 Mīrzã 'Abdul-Rahịm,

I49, I 50, I 55, I69, I 70, I 73

Kh Mun'im Khān, 102

Khāndīsh, 98, 99, I I 5

Kh̆āni-Jahān, 64

Khāqāni, I I 7

Khemkaran, I 55

Khilji, House of, xviii., xix., xx., xxi., 30-4I

Khirad-Afzā-Nāmah, I 50

Khhiẓr Khān, Prince, 32

— Sulțān, 7 I

Khižrābād, 52, 7 I

Khundamir, I 23, I 32

Khurāsān, 6, 23, 77, 87, 90, I 84

Khurramdād, I78

Khurshīd - Jahān - Namah, I IO (note)

Khusrau, 143

Kh wãjagī, Maulānā, 65
Khwājah 'Abdul Șamad Shīrīnqalam Shīrāzī, I 54

- Aḥrār, xxiv., 122

- Hasan, 30

— Khwānd Maḥmūd, I 84

- Kilan, xvi., xxvi.

- Mu'in, 168

- Nașr, 125

— Ușmān Ḥiṣārī, I79 Zikì, 39

Khwājahi-Jahān, 86

Khwāṣ Khān, 77

Kìmiy $\bar{a}-i-S a^{\prime} \bar{a} d a t$, I43

Kirāmitah, 22

Kīrttivāsa, 108

Kishn $\mathcal{F} \bar{s} \operatorname{sh} \bar{i}$, 50

Koh-i-nür, xviii.

Krishna, Bejoy, xi.

Krüger, President, xix.

Kuhrāmī, Qãại Maulānā, 33

Kukah Fūlād, I67

Kumar, Surendra Nath, x.

Kurrā Khān Baghrā, 24

Küshki-Nuzūl, 5 I Shikār, 5 I

LAHORE, 26, 90, I 50 (note)

Lāl, I 54

- Miyān, I 56

Lanepoole, Mr., 123

Lațî, Maulānā, 39

Law, Maharaja Durga Churn, C.I.E., v.

- , Narendra Nath, xiii., xiv., xvii., xviii., xix., $x x .$, xxiii., xxiv., xxvi., xxviii.

—-, Satya Churn, xi.

-, Surendra Nath, $x$.

Layalā, I49

Leyden, xxv.

Lilävatī, 148

Livy's History of Rome, xiii.

London, 176

Loni, 2 I, 67

Lowe, xxvii.

Lubbul-Tuwārikh, I 3 I 


\section{INDEX II}

Lucknauti, 37, 106

Lucknow, I 55, I 88

$M_{A}{ }^{\prime} \bar{A} S I R I-R A H \bar{Y} M \bar{I}, 72,170$

Macaulay, xxi.

Madhavāchāryya, 168

Mādhū, I 54

Madrasah-Tilā, Iog

Māh Malik, xxviii.

Mahābhārata, 52, 107, I10, 147, I 50 (note)

Māham Anaga, 165, 167, 168, 202

Mahāpāttar, I83

Mahes, I 54

Mahes-Mahānanda, I 50

Mahmüd, son of Altamash, 2 I

- Sultān, viii., xiii., xiv., xviii., $3,4,5,6,7,8,9$, IO, I I, $12,13,17$

—, Gāwān, xxiv., 86-89, I I6 96, 97

- Shah, King of Jaunpūr, 101

_-, Tughlaq, Sulțān, 67

Majduddīn, 48

Majma'-ul-Bahrain, I 86

Majma'-ul-Buidā̄n, 149

Majnūn, 149

Makhdūm Sirajuddīn (Shaikh 'Uș̣mān), 37

Makhfi (pen-name of Salima Sultāna), 202

Makhū, I78

Makhzani-Āșār, I 5

Makkah, vii.

Makramat Khān, I 88

Maktūb Khān, I75

Malfüzāti-Tìmürī, 61 (note), 67

Malik Kāfūr, 9I, 92

Malik-ul-Shu'arā Ṭālibaī Āmlī, 180

Mālwa, 96, 97, 98, I25, I 58

Mandu, 97, I25
Manșūr (Nādir-ul-Aṣl), 177

Manucci, Niccolao, I90

Maqbar 'Alī. Sayyid, I26

Maqșūd 'Alī, Mullā, I79

Marāgha, 125

Mars, I 30

Martin, Mr., I76

Maryam, 205

Mashhad, 156, I 57

Masnād 'Alī Husain Khān, 78

Masnawi-i-Ma'nawi, I43

Mașnawis of Shaikh Niāzmī,

I 43

Mas'ūd, Sulțān, 12, I4

- (Slave Dynasty), 22

Mas'iudi, Khwārizmī's, I 2

-, Nasāhī's, I 2

Mathurā, 74, 196

Maulā, Sayyid, 27, 28, 32

Mazhar Karrā, Maulānā, 66 (note)

Mecca, I4, I I 2, I 23

Medina, I4, I I 2

Meerut, 52

Mercury, I 30

Mīhr 'Alī Beg, I64

Minhãjuddīn Qābnī, Maulāna, 38

Minājus Sirāj, xxviii.

Mĩr 'Abdul Lațif, I 3I, I40, I4I

- Q Qāsim Irānī, I 84

Abdullāh, I 57, I 59

Abul Qāsim Gīlānī, I79

'Alī, Mullā, 159

'Alī Tabrīzī, Kh hājah, I 59

Faizullah Anjū, 82, 83

Hamzah, I 42

Ḧusainī Kulankī, I 59

Kalān Muhaddis, 173

Lähuarī, Shaikh, I 84

Ma'șüm Kāshīi, I 80

Muhiammad 'Alî, I I 2 Hashim, I9I

Qāsim, I I 2

Sayyid 'Alī Mashhadi, I 57 


\section{INDEX II}

Mirān Māriklah, Maulānā, 38 Mir'ätul-'Alam, 193

Mïkhund, 12, I23

Mīrzā Ghiyāṣ Beg, I78

— Ibrāhìm, I23

- İraj, I69

- Jān Shìrāzī, I70

— Khairullāh, I97

— Muhammad Haidar, xxiv., 122

- Ziyãuddīn, 184

Mīzän, 188

Modern Review, xi.

Monserrat, Father, I60, 207

Mookerji, Prof. Radhakumud, M.A., $\mathrm{x}$.

Moon. I 30, I 3 I

Moti-ki-Masjid, 166

Mubārak Khiljī, Sulțān, 40, 43

- Sayyid, Sulțān, 71

Mubārakābād, 71

Mufașsal, 122

Muflis Samarqandī Mīrzā, I68, I69

Mughal Dynasty, xxiv.-xxviii., I 2 I -199

Mughal Empire, Keene's, I 87.

Mughis, Qāzī, of Hansi, 30 (note)

Mughīṣuddīn, Qāzịi, 33, 34

$\longrightarrow$ Sayyid, 36

Biānah, Q̄āzịi, 38

Muhammad, Prince, son of Sulțān Balban, 24, 25, 26, 28, I 5

- the Prophet, xx.

Aminn, Ustā, I 57

Amin Mashhadī, 159

Amin-i-Qazwīni, 183

75

Chungī, 31

- Fãẓil Badakhshīi, Mullā, I 84

Ghūrī, Sulțān, xviii., 17, I8, 40,55
Muḥammad Gīsū Darāz, Sayyid, 86

Hādī, 174

Husain, Ustā, I 57

Husain Kashmīrī Zarrīnqalam, I 59

- Jaunpūrī, Mullā, 179

— Khān, Hājīi, I I2, I4I

— Khān Dhārī, 156

- Muhaddis, Shaikh, 197

- Nādir Samarqandi, 183

- Qanaujī, 193

Q̄āsim, 94

—_ Mashhadī, 83

- Quli Quțb Shāh, King of Gulkandah, 95, I I 5 Șadruddīn Khãn Bahādur, Maulawi, I $8 \mathrm{I}, \mathrm{I} 82$

— Șafī, I75 (note) Shāh, Emperor, IO3, IO4. 196-198

- Sh Shāhābādī, Maulānā Shāh, I 49

- Shhāhī, 197

_- Șūfī Māzandrānī, Mullā, I 80

— Sulțān Mīrzā, 69

- Tughlaq. Sulțān, xxii., xxiii., 43-49, 50, I I 5

- Walì-ullăh, 196

Muhib'ali Sayyid, Maulānā, I 84 Muhyyiuddīn Kāshāāni, Qāẓī, 38

Mu'inuddin Janjar, 37

- Luni, Maulānā, 38

Mu'izuddīn Anddihnī, Maulānā, 38

Mu'izzuddīn Sām, Sulțān, 58

Mukalāmah-i-Bāba La àl Dās, 185

Mukammal Khān Gujrātī, I49

Mukhtaruddaulah, 103

Mukund, I 54

Mulăhidah, 22

Mullā Fīrūz Library, xvii.

Shāh, I 85

Multān, 18, 26, 105 


\section{INDEX II}

Mumtāz Maḥal, 202, 204

Munair, I43

Munawwar, Shaikh, I 49

Muni'm Kh IO2, I42

Muntajībuddīn, 36

Munuchiḥr (Mīnūchiḥr), 6

Muqarrab Khān, I 78

Murād, Prince, son of Akbar, I46, 160

Murshid Qulī Ja'far Khān, Nawāb of Bengal, I I I

Murshidābād, II 2

Mushhkīn, 154

Mu'tamad Khān, 174, I78

Mu'yyid Dīwānah, 30

- Jājarmī, 30 (note)

Muzaffar Sh̆āh II., King of Gujrät, 106

Mu'zuddīn Andihnī, 38

Mysore, 96

NĀDIR SHĀH, of Persia, I 26, I97, I98

Nādir-ul-Nukāt, I 86

Nadīyā, 20

Nagarkot, 64

$\longrightarrow$, Rājā of, 64

Nagor, 167

Nagore, 108

Na'īmuddīn, Maulawī, 195

Nai's Fort, 42

Najibuddīn Sāwī, Maulānā, 38

Najmuddīn Intishāar, Maulānā, 38,44

Nala, 149

Nala-Damayantī, 153

Nal-Daman, 152

Namāzgāh, IOI

Nānak Jarjū, I 56

Nandī, Srìkaraṇa, I I I

Naqīb Khān, I47, I48, I 5 I, 165 (note), 178

Nārāyana, Rājā Kansa, 108

Nārnaul, I 37
Nāṣir Khān, 3 I

98 , King of Khāndīsh, Fārūqī, King of

Khāndīsh, 99

- Shāh, King of Bengal, IO7

Nașīruddīn (author), 20, 48

-, Sulțān, 22, 23

— Ghanī, Maulānā, 38

— Karah, Maulānā, 38

- Qubāchah, I8 Șābulī, Maulānā, 38

— Tughlaq Shāh, Sulțān, 66,

67, II 5

- Ubaidullāh, xxiv.

Nașrullah Mușțafā, I49

Nauhattah, 37

Naushābāh, 64

Naushìrawān, I 5

Nazā̄ī Nishāpūrī, Mullā, I 80

$\longrightarrow$, Shaikh, I 84

New Testament, 160

Ni'matullah, I78

Nishāpūr, 19, 102 (note), 104

Nishhāpūrî, Nawāb Sa'ādat Khāān, IO3

Nizām, brother of Shīr Shāh, I 36

- father of Bāz Bahādur, 132

_- Dynasty (Deccan), 194

- Mullā, I93

Nizāmī, Shaikh, I 5, 25, 143

Nizāmuddīn Auliyā, 36, I 24, 204

—— Kalāhī, Maulānā, 38

Noer, Count, xiv., 132, 139

Nundy, Jugal Kishore, xi.

Nūrul Haqq, 100

Nūr Jahān, 202

Nūrullāh, Qāzị, I79

—Q Qāsim Arslān, I 59

Omar Khayyam, xxi.

Oriental Annual, 99

Oriental Biography, xxiv. 


\section{INDEX II}

Ormuz, 83

Oudh, 99, 102, 103

$P \bar{A} D S H \bar{A} H-N \bar{A} M A H, 183$

Padua, 6

Pañchatantra, I 5 (note), 149

Pāṇụuãa, 109

Parāgal Khān, I Io, I I I

Parāgalpūr, I Io

Parameśvara, Kavindra, I I I

Paris, I04, I76

Parwizdād, 178

Patan, 188

Patañjali, 162

Paṭān Dynasty, I 14, I I 5

Paul, Nalin Chandra, B.L., xi.

Persia, xv., 6, I I, 77, 82, 90, 92, 106, 126, 170, 198

Pīr Muhammad, Mullā. I4I, I 5 I (note)

Pìrzādah, 156

Price, Major, xix.

Ptolemy, I25

Punjab, xxii., I25

Purăna Qil'ah, 133, 167

Purbîn Khān, I 56

$Q A B \overline{U S}-N \bar{A} M A H, 143$

Qadam Sharif, 59

Q̄ādir bin Shaikh Rajū, Miyān, 75

Qanauj, 75, I 50, I95

Qandhar, 83

Qänüni-Humāyūn, 124

Qànüni-Islām, 200

Q̄āsim, 157

Q̄āsim Beg, 149

Q̊āzịun-ki-Masjid, 189

Qazwīnī, Nizāmī, 159

Qil'ah Konă Masjid, I66

Qipchaq, I 57

Qissah Hamzah, I 53

Qur'an, xxvii., xlv., I4, 21,22 , $38,39,42,62,63,68,78,84$, $88,96,98$, I I I, I I $2,123,128$,
I63, I76, I9I, I92, 198, 200, 204

Qutah-ul-Qalūb, 37

Quțb Minār, xviii.

Quțb Shāh, Muhammad Qulī,

King of Gulkandah, 95, I I 5

Quțbuddīn, Mullā, 75

- Sultāan (Slave Dynasty), xviii., 18,19

—— Bakhtiyār Kākī, 27

- Khān, 160

- Muhammad Khān, I73

Quṭbul 'Älam, 108, I09

Qutlugh Khāan, 45

RADALF, Pādri(Rodolpho Aquavivá), I45-146

Rafi'uddinn Muhammad Qāzị̂, I 89

Rahīm Khān Khānān, I49

Rahmatullah, I 56

Rajab, father of Fìrūz Shāh Tughlaq, xxii.

Rājah Kãnis, King of Bengal, I06

Rajataraingin $\vec{i}$, I49 (note), I 50 (note)

Rãm, I 55

Rām Dās, I 55, I83

Ramāyāna, I07, I08, 148, 153

Rānā Kumbha, 97

Rangsen, I 56

Ranking, Colonel, xviii.

Raushanuddaulah, 198

Rauzahi-Țähirīn, I49 (note)

Rauzatul-Ahbāb, 176

Rauzatul-Inshā, 87

Rauzatul-Să $\bar{a}$, I 2

Raverty, Major, xxviii.

Raziyah, Sulțāna, xviii., xxviii., 2I, 22, 201

Razm-Nāmah (Mahäbhārata). 148, 153

Rieu, Dr., xix.

Rintambor, 35 


\section{INDEX II}

Risālah-i-Haqnumā, 186

Risālah-i-Qushirī, 37

Risālah-i-Walidìyah, 122

Riyāaul-Salāținn, 108, I10

Roe, Sir Thomas, 177

Roy, Nanda, IO, I I

Ruknuddīn, Sunnāmī, Maulānā, 38

Rüm, 92

Rūmī, Q̄āzīizādah, I 25 (note)

Rūzbahān Shirāzī, Mullā, I79

SA'ĀDAT Khan Nishāpurī, Nawāb, I03

Sachau, xvii.

S'ad Mantakī, 44

Sa'di, Shaikh, xv., 26, 81, II7, I 39

Șādiq Halwā'ī, Mullā, I69 Khān, 163 (note)

Sadri-Jahān Shūstarī, 86

Șadruddīn, Maulānā, 39 , Sayyid, 75

'Alī, 36

Gandhak, Maulānā, 38

Tāwī, Maulānā, 38

Șadr-ul-Shhäria, Maulānā 'Alāuddin, 38

Sa'duddīn Mantāāì 30

Sa'dullah Khān, I9I

Safinat-ul-Auliya, 186

Sāgar Dīghì, IO9

Sa'îdāi Gỉlānî, I 80

Sakinat-ul-Auliya, , 186

Șalāḥuddīn Satrkī, Maulānā, 38

Șālịh, Mullā, I92 (note)

Salim, son of Akbar, I6o

Salima Sulțāna, xxvii., 202

Sāmāna, 178

Samarqand, vii., xxiv., 7, 38, 62, 69,97, I I6, I25

Samman, Burj, I 53

Samrāt, Jantra, I97

Sanbhal, 75

Sānoly (pergana), I 89

Sānwlah, 155
Sarhind, 75

Sarkar, Prof. Benoy Kumar, M.A., $\mathbf{x}$.

Sarud Khān, 156

Sasarām, I00, I 36, I 37

Sattiunnisā, 204

Saturn, I 29, 131

Sava, 92

Sayif Khān, 175 (note)

Sayyid Brothers, the, 196

Dynasty, 7 I, 99

'Alāuddīn, Sulțān, 7 I

Samarqandī, Mulla, I69

Scott, Jonathan, xxiv.

Seal, Dr. Brajendra Nath, M.A., Ph.D., x.

Seville, 104

Shhāh Beg Arghūn, King of Sindh, I05

Shāh 'Ālam II., Emperor, 198I99

Shhāh Jahān, xxvii., 103, 174, I8O-183, I92, 203, 204

Shāh-Jahānābād, I80, I8I, 195

Shāh-Fahān-Nāmah, 128

Shāh Muhammad, Ustā, I 57

Shāh-Nämah, 6, 8, 9, 25, 90, I43, I 50

Shāh Rukh, 68, 69

Shahābuddīn, Maulānā, I23, 127

一, Qāżị, I 37

Shahābuddin Abul 'Abbās Aḥmad, 44, 48

— Aḥ̣mad Khhān Bāzill, 167 (note)

—_ Daulatābādī, Qãzịi, 65, I00 Khalīīi, Maulānā, 39

—_ Multānī, Maulānā, 38

Sadr Nashīn, 36

Sha'î̀ā, 180

Shaikhū, IO2

Shaikh-ul-Islām Nizām-ul-Haqq

Wauddin, 58

Shakarganj, Shaikh, 27

Shamsuddin, 48 


\section{INDEX II}

Shamsuddīn Altamash, Sulțān, xviii., 58, 59

- Bahī, Maulānā, 38 Gāẓrūnī, Qāậ̃, 38 Tum, Maulānā, 38

Shamsul Mulk, 36

Shāan Jahān, I I I

Sharafuddaulah, Nawāb, 197

Sharafuddin Husain, 167

—_ Sarbāhī, Qãzịi, 38

Sharf, I 43

Sharhi-T'arif, 37

Sharif Khān, I60

Shherī, Mullā, 148

Shihāl Khān, I 56

Shir Mandal, I33

- Shăh, xix., xxvii., 99, I 33 , I 36-1 38, 167

Shìräz, vii., 26, 97, 104, 108, 163

Shirgarh (Qanauj), I49

Shoberl, 96

Shukrullāh Shirāzī, Mullā, I79, I 84

Sìha, village, I 89

Sikandar Lūdì, Sulțān, 73-78, 79, 100, IOI, I 6

Sikandar-Nämah, 44, 137

Sìkrī, 75

Sil, Moni Mohun, xi.

Silāpūr, 113

Sìlchānd, Lālā, 162, 163

Sindh, 18, 105

Sinhāsana Battīsī, I 50

Siräj, 22

Sirāj, 'Afíf, Shamsi, xxiii., 5I, 52

Sirr-ul-Asrār (Sirr-ul-Akbar), 185

Siyālkūṭ (Sealkot), r89, 190

Siyarul'Arifin, 73

Siyarul-Mulk, 102

Siyarul-Mutaakhkhivin, I I2, II3, 133

Sleeman, Lieut.-Col., I 86

Smith, L. F., I 28

Socrates, $\mathrm{xxi}$.
Somerset, Protector, xxiii.

Somnāth, 7

Spain, 204

Srigyān Khān, I 56

Stephen, Carr, 60-6r (note), 66, I34, I 8 I

Stewart, 108

Subhān Khān, I 56

Subuktigin, 6

Sulțān 'Alī, Mullā, I 32 (note)

Sun, 129

Sundra, village, I 89

Sürahi-Iqra', 128

Surat, 188

Sūr Dãs, 156

T. ABAQĀTI-AKBART, I66, I68, 169

Tabaqāti-Nāșirì, xxviii., 22, 23

Tabrīz, 38

Tabșìrātul Näzirīn, 197

Tafrīhul-'Iniärät, 180

Tafsiri-Husaini, 176

Tafsīri Kashshāf, 176

Tājak, I49

Tāji Salmānī, I 59

Tājuddīn, Sayydi, 36

- 'Iraqi, 30

- Janjar, 37

- Kalāhī, Maulānā, 38

- Maqdūm, Maulānā. 38

Tākī Qulī Khān, I I 2

Tamerlaine (Tìmūr-i-Lang), I 2 I

Tamerlane, History of, 132

Tangier, 46

Tānsen, Miyān, 155

Tāntarang Khān, I 56

Tapti, 99

Taqi Sharīfī, Amīr Mīr, I69

Tärā, 155

Tārikhi-Alfī, I 50

- Badà'inìi, I45, I48, I64 Farrukhābād $\bar{z}, 196$

Firishtah, 94

Firiziz-Shāhì, 48

Guzidah, 4 


\section{INDEX II}

Tārīkhi-Fān-Fahān, 175

- Mahmìdi, 44

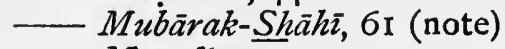

- Muzaffari, 122

- Rashīdi, 122

- Sa $\bar{\imath} \bar{m}-S h \bar{a} h \bar{i}, 140$

- Tăhiri, I I7

- Yamiñ̄, 6

Tāsh Beg, 157

Tawārikh, 126

Taylor, $\bar{M}$ r. Meadows, 87

Tazkiratul-'Ulamā, 102

Tażkiratul-Wāqi' āt, I 32

Thāneswarī, Sulțān Hājī, I48

Thevenot, 89 (note), 95

Tibbi-Sikandarī, 77

Tî̀mūr Beg, xxvi., 60 (note), $67-69,70,121,15$ I, I 59

Timür, Life of, 182

TTipu Șãhile, 96

Topra, 52

Trivenī, I68

Tughlaqābād, 42

Tughlaq Dynasty, xxi.-xxiii., 42-70

Tulumba, 75

Tuqyai Shūstarī, Mullā, I79

Türān, 26

Turkey, 106

Turkistan, 92

Turner-Macan, Captain, xvi.

Tūs, 9, 10

Tīzaki-Fahāngīrī, I39, I75

'UBAID, 44

'Ubaidullāh Aḥrār, 122

Uhiduddīn Mulhu, Maulānā, 38

Ujiahuddīn Rāzī, 38

Ujiyāuddīn Pailī, Q̄āẓī, 38

Ujjain, I96

Ujjain and Dhar, I25

Uljaitu Khān, Sulțān of Persia, 68

Ulugh Beg Mĩrzā, 125, 150

Khāni A'zam, 23

'Umar Shaikh, I42 (note)
'Umārpūr, I08

'Unșurī, 5, 6, 7, 8

Upanishads, 185

'Ușmān, Shaikh (Makhdūm Sirajuddin), 37

'Ussmān Turmūzi, Shaikh, 26

'Utārid (Mercury), I 3 I

'Utbī, 6

'Uzeerī Rāzì, 6

VEDĀNTA, I62

Vedas, 81, 184, I 85

Venus, I31, I33

Vidyāpati, I07

Vikramājit, Rājah, 125

Voltaire, xiv.

Vyäkaraṇa, 162

WĀJĪHUDDĪN AHMAD, SHAIKH, I63 (note)

Wāqi'āti-Bābarì, 127, 149, I74

- Fahāngìrī, I40

Mushtāqū 77

Wilson, Professor, 149 (note)

Wordsworth, $\mathrm{xxi}$.

YĀDAVA Dynasty, 9I

Yākūt Musta'șamī, I 59

Yaldūz, I 8

Yamunā, 53

Yazdi, 6I (note)

Yūsuf, Ustā, I 57

Yūsuf 'Ádil Shhāh, King of Bījāpūr, 93

Yiusuf and Zulaikha, 169

Yūsuf bin Jamāl, Sayyid, 6I (note)

- Shāh, of Bengal, 108

ZAFAR-NA $M A H$, 6I (note), I 53

Z̈ăhir Dihlawī, IOO

Z̆ahīruddīn Bhakrī, Maulāna, 38 


\section{INDEX II}

Zahīuddin Lang, Maulānā, 38 Zain Khwāfî, Shaikh, 127

Zainab, 204

Zainuddin, Shaikh, 98

- Khäfĩ, Shaikh, I34

- Maḥmūd Kāmāngarh, Maulānā, 169
Zainuddin Shhirāzì, Maulānā, 44 Zainul 'Ábidin, King of Kashmir, 105

Zíbunnisā Begam, xxvii., 204

Zinuddīn Nāqlāh, Qāzī, 38

Ziyāuddin Sunnāmī, Maulānā, 39

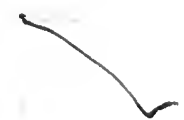




\title{
INDEX III.-CHRONOLOGICAL
}

\section{I.-THE MUSLIM EMPIRE IN INDIA.}

\author{
House OF GHAZNī. \\ (366-582 A.H., 976-I I 86 A.D.)
}

NotE.-Dates not found in the author's text are taken from Poole's Medicual India under Muhammadan Rule. Some dates are not easily determined ; but those given are generally accepted as correct.
A.H.
388-42 I Mahmūd, soldier, iconoclast and patron of 998 -IO30 learning
415 His peace with Nanda Roy
'Unsuri, 7 ; Firdausī, 8-10
42 I-432 Masūd I., founder of schools and colleges IO30-IO40
45 I-492 Ibrāhìm, an excellent penman 1059-IO99
492-508 Bairām bin Mas'ūd, ardent patron of IO99-I I I 4 letters
Kalïlah-Damnah, translated into Per- sian, 15

HOUSE OF GHŪR.

(To 602 A.H., I206 A.D.)

544-556 'Alāuddīn, a vandal

569-602 Muhammad, an educationalist

I $149^{-}$I I6I

I $174-1206$

Slave Dynasty.

$$
\text { (602-686 A.H.f I206-1 } 287 \text { A.D.) }
$$

602-607 Qutbuddin, destroyer of Hindu temples

607-633 Altamash, a liberal ruler

Amir Kūhānī, Nașīruddīn, Fakhr-ulMulk, 20, 2 I

634-637 Sultāna Raziyah, patroness of learning I236-1240

637-639 Bairām

I $240-1242$

639-644 Mas'ūd

1 206-1 210

$1210-1236$

$644-664$

Nașiruddinn, student, scholar and hermit 


\title{
INDEX III
}

A.H.

664-686 Balban, protector of the learned

Literary societies of Delhi, 24-26; rise of Delhi as a literary centre, 27

Amir Khusrau and Amir Hasan, 24, 25

Old age of Shaikh Sa'dī, 26

686-689 Kaiqubād, a profligate

\author{
A.D. \\ I $266-1287$
}

KhiLjī DyNaSTy.

(689-720 A.H., I 290-I 32 I A.D.)

689-695 Jalāluddin, friend of the learned

Royal literary parties, 31

$1290-1296$

Sayyid Maulā, 32

695-7I5 'Alāuddīn, illiterate and capricious tyrant

Paradoxical literary brilliance under an

I 296-I 316 unlettered ruler, $39-40$

Plenitude of learned men in Delhi, 38-40

Better understanding between Hindus and Muslims, 40

695 Hauz Khāṣ reservoir made, 60 (note)

716-720 Mubārak, a debauchee, who, however, restored endowments confiscated by 'Alāuddīn

Tughlaq Dynasty.

$$
\text { (720-8I } 7 \text { A.H., I 32I-I4I4 A.D.) }
$$

720-725 Ghiyāșuddīn, law-giver

Blight of Alāuddin's rule evidenced in

I $321-1325$ a lowering of the literary standard at Delhi, 43

725-752 Muhammad, brilliant but whimsical and cruel

Sacrifices Delhi to Daulatābād, 46-47

Barnī, the great historian, 48

Charitable institutions, 45

742 Ibn Bațūtah visits India, 46

I 34 I

$752-790$

Fìrūz, a good and liberal administrator

Care for Hindu monuments, 52

753

College at top of Hauz Khāș, 60 (note)

1295

I $316-1321$

I $287-1290$

$1325^{-1} 35^{1}$

Foundation of Jaunpūr, IOO-IOI (note)

Public buildings, 57-59

Fīrūz-Shāhī-Madrasah, 60

Further approximation of Hindus and Muslims, 64 


\section{INDEX III}

ธ.н.

790-8I7 Dark period, covering ravages of Tīmūr

792 Tomb of Fìrūz built at Hauz Khās

801-802 Invasion of Tīmūr (Tamerlane), who wrecked Delhi and other centres of learning; yet had respect for learned men, and built a college in Samarqand, where he was buried, $67-69$

Sayyid Dynasty.

(8I7-855 A.H., I4I4-I45 I A.D.)

817-824 Khiẓr Khān, founder of Khizerābād

\section{LŪDī Dynasty.}

$$
\text { (855-932 A.H., I } 45 \text { I-I } 526 \text { A.D.) }
$$

855-894 Bahlūl, founder of Agra

894-923 Sikandar, benefactor of learning, but a bigoted Musalmān

Formation of Urdu or Hindustani out of native and foreign elements, 76

Indian medical science studied by Muslims, 77

923-932 Ibrāhīm, conquered by Bābar

Mughal Period.

$$
\text { (932-1275 A.H., I 526-1857 A.D.) }
$$

932-937 Bābar, scholar, poet, and musician

Educational services performed by the State, 127

Book illustration introduced by Bābar, 126

937-946 Humāyūn, astrologer and savant

Learned and religious men take precedence of nobles, 130

Mīr 'Abdul Lațif, I 3 I

Jauhar, 132

94I Deaths of Shaikh Zainuddīn Khāfĩ and of Khundamir

946 Humāyūn deposed by Shìr Shāh
I 5 I 8-I 526

$145 I-I 488$

I $488-15$ I 8

A.D.
I 388-I 4 I 4
I 389
I 398-I 399

I 4 I 4-I 488

I 526-1 530

I 530-I 539

I $534-1535$

I 539 


\section{INDEX III}

A.H.

946-952 Shī Shāh, a friend of learning

A.D.

952-960 Islam Shāh

962-963 Humāyūn's restoration and death

963-IOI4 Akbar the Great, statesman and patron of letters, a most enlightened and liberal monarch

98 I Builds 'I bādat Khāna

Holds famous assemblies therein,

I 545-I 552

I $555-$ I 556

I 556-I 605 I44-I 47

Favours Hindu learning and literature and promotes the translation of the Mahābhārata, Rāmāyana, and other Sanskrit classics into Persian and Hindi, 147-1 50

Co-education of Muhammadans and Hindus, I 60-16I

Technical improvements in education, I6I

969 Madrasah of Māham Anaga, 165-167

'Abdul Rahīm, great patron of letters, I69-I70

1014-1037 Jahāngīr, connoisseur of books and I605-1628 pictures

Excellence of painting in his reign, I87

Farrukh Beg, Abūl Hasan, Manșūr, painters, $176-177$

Jahängìr's law of intestacy, I74-5

I037-1069 Shāh Jahān, builder and restorer of 1028-1659 colleges

Prince Dārā Shikūh, great scholar and patron of $\overline{H i n d u}$ literature and religion, I 84-I 86

$P \bar{a}$ shāh $N \bar{a} m a h$ and its author, I83

I056 Death of Nūr Jahān

I067 Upanishads translated into Persian, I 85

I069-I I I9 Aurangzib, promoter of Muslim education and learning

Pioneer of compulsory education and of grants to students according to proficiency, I87-189

Educates his eldest daughter, 204

Views on the education of princes, 192

I I 19-I I 24 Bahādur Shāh, under whom Muslim rule begins to decline

I I 3I-I I6I Muḥammad Shāh, patron of astronomy

1646

I657

1659-1707

I707-17 12

$1719-1748$ 


\section{INDEX III}

A.H.
II36 Observatory built at Delhi by Jai
I72.D. Singh, 196

Muhammad Shāhī Astronomical Table, 197

Nādir Shāh sacks Delhi and carries away the Imperial Library, 198

1173-1221 Shäh 'Âlam II.

Ghulām Qãdir pillages the partly re-

$1757-1806$ stored Imperial Library, I98-199

II.-THE MINOR MUSLIM KINGDOMS.

I. BAHMANī.

$$
\text { (748-933 A.H., I347-I } 526 \text { A.D.) }
$$

748-759 Hasan Gangu, a Brāhmaṇa, acquainted 1347-135\$ with Persian

Probably earliest instance of a Brāhmana accepting office under a Muslim prince, $8 \mathbf{I}$

776-780 Mujāhid Shāh, fluent Turkish scholar 780-799 Maḥmūd Shāh, called Aristotle by the Deccanese

$780 \quad$ Founds madrasah for orphans, 82

Relations with Hāfiz, 82-83

799 Ghiyāșuddīn Shāh and Shamsuddīn Shāh

800-825 Fìrūz Shāh, learned in languages

Sends ships annually to invite visits from learned foreigners, 85

$810 \quad$ Observatory built near Daulatābād

825-838 A ḥmad Shāh I., ill-disposed towards Hindus

867-887 Muhammad II., a learned king

Maḥmūd Gäwān, the king's minister, great patron of learning and builder of a magnificent college at Bĩdar, $86-89$

887-924 Maḥmūd Shhāh II., a profligate

$1375-1378$

$1378-1397$

I 378

I 397

I $397-1422$

1407

$1422-1435$

1463-1482

$1482-1518$ 


\section{INDEX III}

2. $B \bar{I} J \bar{A} P \bar{U} R$.

(895-I096 A.H., I489-I686 A.D.)

895-9I6 'Ādil Shāh, accomplished in literature I489-I5IO and music

916-94I Ismā'îl 'Âdil Shhāh, musician, poet, and I5IO-I534 painter

94I-965 Ibrāhìm 'Ādil Shhāh I.

Many Brâhmanas appointed to the revenue department, 93

Public accounts begin to be kept in Hindī, 93

987-1004 Ibrāhīm 'Ādil Shāh II.

\section{Ahmadnagar.}

(From about the beginning of the 16 th century A.D.)

Aḥmad Niz̄ām Shhāh, the first king, introduced the practice of single-stick, and schools for this and for wrestling were established in his city

\section{Gulkandah.}

Muhammad Qulī Quțb Shāh, who reigned about the end of the 16 th century and beginning of the I 7 th century A.D., built the Chahār Minnār Madrasah, one of the most splendid buildings in Haidarābād

\section{MĀLIVA.}

(804-937 A.H., I4OI-I 53 I A.D.)

839-874 Mahmūu Khiljī, patron of learning and letters

I 435-1469

Under him Mālwa became a great centre of learning, 97

874-906 Ghiyāșuddin, who appointed schoolmistresses for the instruction of the ladies of his harem

(?)-937 Bãz Bahādur, a too enthusiastic musician, conquered by Akbar 


\section{INDEX III}

\section{$6 \underline{\mathrm{KHA} N \mathrm{~N} \overline{\mathrm{I}} \mathbf{S H}}$.}

A.H.

Nazar Khān, the second sovereign, who resigned about the last quarter of the 14th century A.D., had Shaikh Zainuddin as his priest

Nāṣir Khān Fārūqĩ, a great patron of letters, ruled for about forty years and raised his principality to a high position in the literary world. He was about contemporary with the Sayyid Dynasty and with Ibrähim Sharqi of Jaunpūr, during the first half of the 16th century A.D.

7. JAUNPŪR.

(796-88 I A.H., I 394-1 477 A.D.)

803-844 Ibrāhīm Sharqī, famous patron of learning and letters

The court of this prince far outshone that of Delhi at the time, and his capital became a famous university city, IOO

844-86I Maḥmūd Shhāh, son of Ibrāhīm. His wife, Bībì Ràjī, built and endowed a college and other buildings

881 Annexation by Delhi

I 47 Nawāb Sa'ādat Kh hān Nishāpūrī appointed Subādār and confiscates stipends

$1401-1440$

A.D.

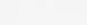




\section{INDEX III}

9. Sindh, KASHMīR, AND GUJRĀT.

A.1I.

Shāh Beg Arghūn, of Sindh, well read and a great patron of letters, reigned about the third decade of the 16 th century A.D., 105

Zainul 'Ābidin, of Kashmir, patron of literature and the fine arts, was about contemporary with Shāh Beg A rghūn, of Sindh, 106

974 Husain Khān; Walī of Kashmir, built I 566 or I 567 madrasahs

917-932 Muzaffar Shāh II., of Gujrāt, a royal I5II-1525 Mrcenas

IO. BENGAL.

(599-984 A.H., I 202-I 576 A.D.)

607-623 Governor Ghiyāșuddin, liberal patron of arts and letters

681-726 Nāṣir Shāh, son of Sulțān Balban of Delhi, great patron of Bengali

Ramāyāna and Mahābhīrata translated into Bengali, 107

768-774 Ghiyāşuddin II., poet and contemporary I 367-1373 of Hāfiz.

788-795 Rājah Kānis, granted pensions to learned I 385-I 392 Muslims

879-886 Yūsuf Sḩ̄āh

Ruins of madrasah near Umārpūr dated 1479 A.D.

899-925 Husain Shhāh, great patron of Bengali

Founded college in memory of Qutoul 'Âlam

$1474-148$ I

I 493-I 5 I 8

I 106-I 127 Na wāb Murshid Quli Ja'far Kh hān, learned and pious

$1704-1725$ 


\section{OTHER WORKS BY THE SAME AUTHOR. STUDIES IN ANCIENT HINDU POLITY. \\ Vol. I.}

Based on the "Arthasâstra" of Kautilya. With an Introductory Essay on the Age and Authenticity of the "Arthasâstra" of Kautilya by Professor Radhakumud Mookerji, M.A., Ph.D., Premchand Roychand Scholar, Author of "A History of Indian Shipping," \&c.

Crown 8vo. pp. viii +202 . Price $3 s .6 d$. net.

\section{SELECT OPINIONS.}

India.- ". . Mr. Law may be said to have accomplished his task . . . with great skill and learning. . . "

The Scottish Historical Review.- ". . . this well-written treatise. It gives a complete system of polity and deals with most parts of Indian life from the law of contract to the keeping of elephants."

The Pioneer.- "An excellent little book. . . . Mr. Law is a century in advance of his countrymen in accuracy and sobriety of statement."

The Englishman.- "A neat, hardy volume, well got up. . . . What he has done, he has done well. Ife writes with thorough knowledge ..."

The Times of India.-“. . . Nr. Law as well as Mr. Mookerji have acquitted themselves creditably of their important task of rendering Kautilya and his great treatise better known to English readers, and we hope they may soon complete their works."

The Bengalee.- ". . We have perused this work with pleasure and with a sense of patriotic pride. . . . We congratulate the Kumar on his work . .."

The Indian Social Reformer.- "Mr. Law's 'Studies' is one of the works which afford gratifying proof of the intelligent interest which our educated men are beginning to evince in the history and literature of ancient India. . . ."

The Commonweal._“. . . Mr. Law's book . . . eminently readable. . . . Is introduced by a very learned introduction from the pen of the famous author of 'A History of Indian Shipping' . ..."

The Hindu Patriot. - "The Kumar has evinced critical acumen and powers of research of no ordinary order. . . . The book before us brims over with interest from cover to cover, and the informing introduction, which has been furnished by Prof. Radhakumud Mookerji, of 'Indian Shipping' fame, invests it with additional value. . . ."

\section{PROMOTION OF LEARNING IN INDIA}

\section{By Early European Settlers. (Up to about 1800 A.D.)}

With an Introduction by the Venerable WALter K. Firminger, M.A., B.D., Archdeacon of Calcutta.

Crown 8vo. pp. xxviii + I6o. With 2 Illustrations. Price $4 s$. $6 d$. net.

This volume gives a connected history of the educational activities of the Europeans in India up to about 1800 A.D., - the efforts of the East India Companies as well as of the European missionaries and private individuals for the diffusion of education, not only among the Europeans in the Companies' settlements, but also among the Indians. Educational institutions founded by them, schools, colleges, and libraries have been noticed in the book.

LONGMANS, GREEN AND CO.

LONDON, NEW YORK, BOMBAY, CALCUTTA, MADRAS 


\section{Other Works on Indian History and Culture}

1. The Positive Sciences of the Ancient Hindus. By Dr. Brajendranath Seal, M.A., Ph.D., King George V. Professor of Mental and Moral Science in the Calcutta University. 8vo. pp. viii +296 .

I $2 s .6 d$. net.

2. A History of Indian Shipping and Maritime Activity from the Earliest Times. By Professor Radhakumud Mookerjr, M.A., Ph.D., Premchand Roychand Scholar. With an Introduction by Dr. Brajendranath Seal, M.A., Ph.D. $\quad 75.6 d$. net.

3. The Fundamental Unity of India (from Hindu Sources). By Professor Radhakumud Mookerji, M.A., Ph.D. With an Introduction by Mr. J. Ransay Macdonald, M.P. $\quad 3$ s. $6 d$. net.

4. The Foundations of Indian Economics: By Professor Radhakamal Mookerji, M.A. With 12 Illustrations. 8vo.

(In the Press.)

5. The Science of History and Hope of Mankind. By Professor Benoy Kumar Sarkar, M.A.

2s. $6 d$. net.

6. An Introduction to the Science of Education. Translated from Professor B. K. Sarkar's Bengali edition by Major B. D. BASU, I.M.S.

3s. 6 d. net.

7. The Geographical Dictionary of Ancient and Mediæeval India. By Nundolal Dex, M.A. Second Edition.

(In the Press.)

LONGMANS, GREEN AND CO.

LONDON, NEW YORK, BOMBAY, CALCUTTA, MADRAS

8. The Positive Background of Hindu Sociology. By Professor B. K. Sarkar, M.A. (Panini Office, Allahabad). $\quad 8 s$. or Rs. 6

9. The Folk-Element in Hindu Culture. By Professor B. $\mathrm{K}$. SARKar, M.A.

(In the Press.) 
、 



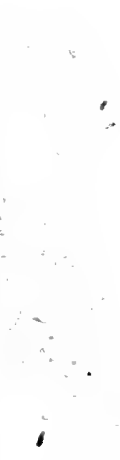

$x^{2}$
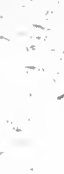


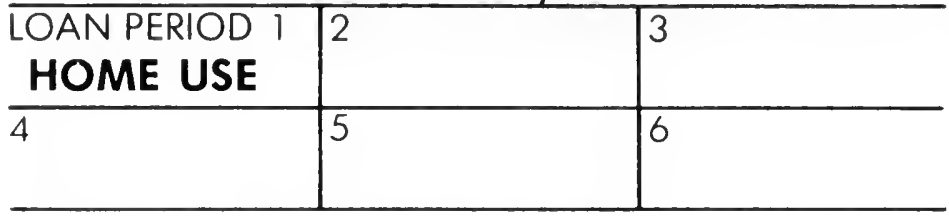

ALL BOOKS MAY BE RECALLED AFTER 7 DAYS

Renewals and Recharges may be made 4 days prior to the due date.

Books may be Renewed by calling $\mathbf{6 4 2 - 3 4 0 5}$

DUE AS STAMPED BELOW

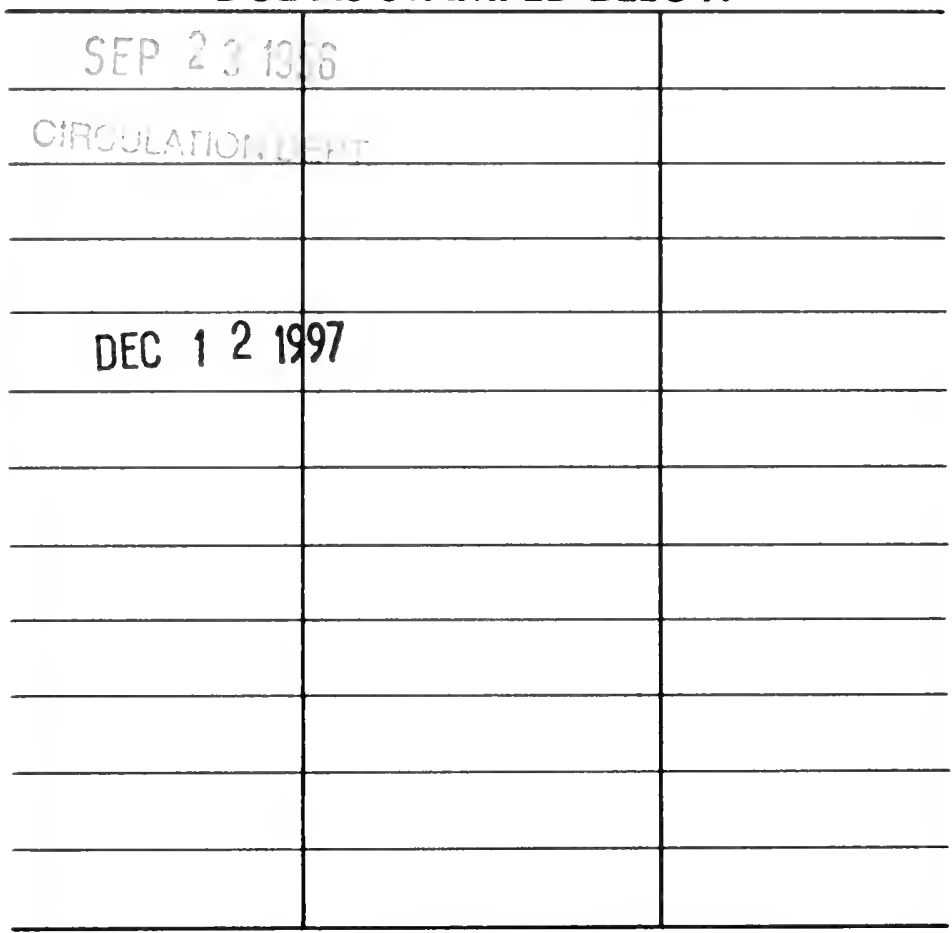

UNIVERSITY OF CALIFORNIA, BERKELEY

FORM NO. DD6 BERKELEY, CA 94720 
U. C. BERKELEY LIBRARIES

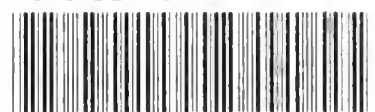

C046243964

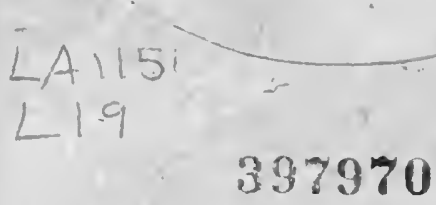

UNIVERSITY OF CALIFORNIA LIBRARY 


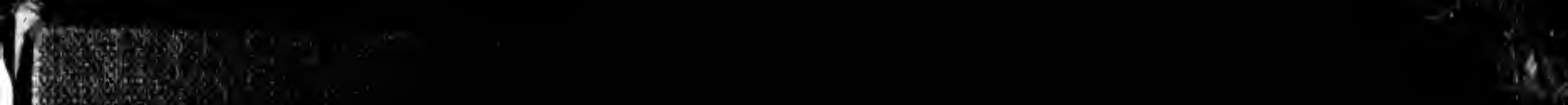

1.

\%

政

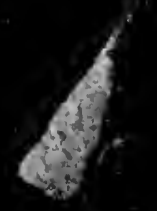

